\title{
Using Voluntary Standards in the Federal Government
}





\section{Using \\ Voluntary Standards \\ in the \\ Federal Government}

\section{Conference Summary and Viewgraphs}

U.S. DEPARTMENT OF COMMERCE

Technology Administration

National Institute of Standards

and Technology

Gaithersburg, MD 20899-0001

September 1997

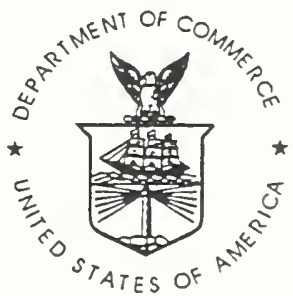

U.S. DEPARTMENT OF COMMERCE

William M. Daley, Secretary

TECHNOLOGY ADMINISTRATION

Gary Bachula, Acting Under Secretary for Technology

NATIONAL INSTITUTE OF STANDARDS

AND TECHNOLOGY

Robert E. Hebner, Acting Director 



\section{Acknowledgments}

We would like to thank the following individuals for their contributions to the success of the conference: Judith Baker, Christine DeVaux, Krista J. Leuteritz, Joan Tyler and Shirley Walters. We would also like to thank Walter Leight and Maureen Breitenberg for their review of this document.

Dr. Belinda L. Collins

Office of Standards Services 


\begin{abstract}
Using Voluntary Standards in the Federal Government is a compilation of presentations given at a NIST-sponsored conference held on September 8, 1997. The purpose of the conference was to foster better understanding among Federal agencies of the private sector standardization process. The conference took place as part of a major effort by NIST to implement the National Technology Transfer and Advancement Act (NTTAA). The NTTAA gives NIST responsibility to coordinate standards and conformity assessment activities with other Federal agencies, state and local governments, and with the private sector.
\end{abstract}

Key Words:

conformity assessment; NTTAA; private sector; voluntary standards 


\section{TABLE OF CONTENTS}

Acknowledgements .......................... i

Abstract . . . . . . . . . . . . . . . . . . . . . . . ii

Summary . . . . . . . . . . . . . . . . . . . . . . . . ii

Conference Agenda . . . . . . . . . . . . . . . . . . . . . iv

P.L. 104-113 Federal Use of Voluntary Standards . . . . . . . . . . . . Section 1

Belinda L. Collins, Director, Office of Standards Services

The ANSI Role ............................ Section 2

Sergio Mazza, ANSI President and CEO

Regulatory Standards Panel on Health and Safety ............ Section 3

Moderator: Richard (Gene) Feigel, ASME Senior Vice President

Panelists: Howard Hime, Department of Transportation

Richard Felder, Department of Transportation

Gilbert Millman, Nuclear Regulatory Commission

Colin B. Church, Consumer Product Safety Commission

Regulatory Standards Panel on Energy/Environment . . . . . . . . . . Section 4

Moderator: Mary C. McKiel, Environmental Protection Agency

Panelists: $\quad$ Steven McNeely, Environmental Protection Agency

Caroline B. Purdy, Department of Energy

Procurement Standards Panel ...................... Section 5

Moderator: Gregory Saunders, Department of Defense

Panelists: James D. Nicolo, Department of Defense

Bruce L. Mahone, Aerospace Industries Association

Howard Bloom, National Institute of Standards and Technology

National Strategic Standards Panel . . . . . . . . . . . . . . . Section 6

Moderator: Richard Serbu, Department of Energy

Panelists: $\quad$ Michael Schagrin, Department of Transportation

Michael Fitzmaurice, Health and Human Services

Donald Marlowe, Food and Drug Administration

Gary Fischman, Food and Drug Administration

Biographies of Moderators and Panelists

Section 7

Conference Participants

Alphabetical List by Name 



\section{SUMMARY}

On September 8, 1997, The National Institute of Standards and Technology held a day-long conference on "Using Voluntary Standards in the Federal Government" focused on successful use by Federal agencies of voluntary consensus standards developed by the private sector.

Chaired by Dr. Belinda Collins, Director of the Office of Standards Services, the conference was part of the ongoing implementation of the National Technology Transfer and Advancement Act (NTTAA). The Act (P.L. 104-113) was signed into law by the President on March 7, 1996, assigning to NIST a leadership role in coordinating standards and conformity assessment activities among federal, state and local government agencies, and with the private sector, to meet the needs of U.S. industry in the global marketplace. Collins provided background on the Act, which contains specific provisions for standards-related activities. Federal agencies must compare private sector voluntary standards used in scientific investigations, engineering, manufacturing, commerce, industry, and educational institutions with those developed by the Federal government.

After introductions and a keynote speech delivered by James Turner (Professional Staff Member, House Committee on Science), Sergio Mazza, President of the American National Standards Institute (ANSI) reviewed the generic process for developing U.S. voluntary standards. Four panels then presented examples of the successful use of voluntary standards for governmental procurement or regulatory purposes, and for meeting future national needs. Panelists described the impact of particular standards on agency goals, the process of developing the voluntary standards, and problems that had been encountered and resolved.

The conference was attended by more than 200 participants, including representatives from eight major standard developing organizations and from Federal agencies that work with the private sector to develop mutually beneficial standards, resolve policy issues, and use standards for Federal procurement or regulation. Among the Federal agencies represented were: The Consumer Product Safety Commission (CPSC), the Department of Defense (DOD), the Department of Energy (DOE), Department of Labor (DOL), the Department of Transportation (DOT), the Environmental Protection Agency (EPA), the Federal Bureau of Investigation (FBI), the Food and Drug Administration (FDA), the Federal Highway Administration (FHA), the Federal Communications Commission (FCC), the General Services Administration (GSA), the Department of Health and Human Services (HHS), the Department of Housing and Urban Development (HUD), the National Aeronautics and Space Agency (NASA), the Department of Agriculture (USDA), National Archives, U.S. Customs, U.S. Postal Service, U.S. Treasury and the National Institute of Standards and Technology.

Overall, the conference fostered better understanding among federal agencies of the private sector standardization process and paved the way for increased future collaborative efforts. 

AGENDA 



\section{$A G E N D A$}

\section{"Using Voluntary Standards in the Federal Government" Date: September 8, 1997 Location: NIST, Red auditorium}

\section{8:00 a.m. Registration \& Coffee (Exhibits/networking opportunities) \\ 8:20 a.m. Welcome \\ Dr. Robert Hebner, Acting Director of NIST}

8:30 a.m. Opening Remarks

Dr. Peter L. M. Heydemann, Director of Technology Services

8:40 a.m. Facilitator (provide background on NTTA, explain the Law)

Dr. Belinda Collins, Director of the Office of Standards Services

9:00 a.m. Keynote Address

Mr. James H. Turner, Professional Staff Member, House Committee on Science

9:20 a.m. The ANSI Role - Sergio Mazza, ANSI President and CEO

9:40 a.m. Break (Exhibits/networking opportunities)

10:00 a.m Regulatory Standards Panel on Health/Safety

Moderator: Mr. Richard (Gene) Feigel, ASME Senior Vice President of

Codes and Standards

Case Study \#1

Speaker: Mr. Howard Hime, Chief, Office of Standards, Evaluation and Development, Department of Transportation (DOT)

The U.S. Coast Guard has been an active participant in codes and standards development, particularly the Boiler and Pressure Vessel Code. Mr. Hime will discuss the on-going role of the USCG in private sector standards development and the value those standards bring to their role as regulators. The Standards Development Organizations providing the forum for this case study are ASTM, ASME and NFPA.

\section{CASE Study \#2}

Speaker: $\quad$ Mr. Richard Felder, Associate Administrator, Department of Transportation (DOT), Office of Pipeline Safety

DOT has made use of private sector standards for their gas transmission and liquid petroleum pipeline regulations since the 1960's. Mr. Felder will discuss the development of risk management standards for the pipeline industry, and how DOT is moving toward adoption of consensus standards for pipelines and liquefied petroleum gas storage. The Standards Development Organizations providing the forum for this case study are NFPA and ASME.

Case Study \#3

Speaker: $\quad$ Mr. Gil Millman, Program Manager, Codes and Standards, Nuclear Regulatory Commission

The NRC has relied upon consensus standards to develop nuclear codes and standards for the construction and in service inspection of nuclear power plants. Mr. Millman will discuss the standards making process between a regulatory agency and a standards development organization. The Standards Development Organization providing the forum for this case study is ASME. 
Case Study \#4

Speaker: Colin B. Church, Consumer Product Safety Commission (CPSC)

Saving lives and reducing serious injuries is the business of the CPSC. Mr. Church will discuss how voluntary safety standards are making our homes, schools and recreation areas safer places. The Standards Development Organization providing the forum for this case study is UL.

11:05 a.m. Regulatory Standards Panel on Energy/Environment Moderator: Mary C. McKiel, Director of Standards Network, Environmental Protection Agency

Case Study \#1

Speaker: $\quad$ Steven McNeely, Environmental Protection Agency, Office of Underground Storage Tanks

In the U.S. there are some 1,200,00 underground storage tanks that pose a risk to the environment. The EPA set a deadline of 1998 for these tanks to be upgraded or replaced. EPA and other key stakeholders (petroleum companies, environmental professionals, and others) debated the issues, searched for and developed a common solution. The Standards Development Organization providing the forum for this case study is ASTM.

Case Study \#2

Speaker: $\quad$ Caroline B. Purdy, Program Manager for Characterization, Monitoring, and Sensor Technology Integrated Program, Department of Energy (DOE)

DOE sponsored a collection of 22 states to work together to develop solutions to environmental problems and reduce barriers to the introduction of innovative technologies into the marketplace. One successful challenge was the development of a Site Characterization Standard. The Standards Development Organization providing the forum for this case study is ASTM.

\section{1:45 a.m. Question \& answer session}

12:00 p.m. Procurement Standards Panel

Moderator: Mr. Gregory Saunders, Deputy Director, Accession Practices, Office of the Assistant Secretary of Defense

Case Study \#1

Speakers: James D. Nicolo, Director Commodity Management Group, Defense Industrial Supply Center, Department of Defense (DoD) and Bruce L. Mahone, Director of Standardization, AIA

For DoD, the primary benefits of voluntary consensus standards usage are reduced acquisition costs and removal of impediments to commercial-military integration. As a means of reducing administrative work and increasing accessibility, the Department has recommended the adoption of voluntary consensus standards. To date, approximately 7,500 voluntary consensus standards have been adopted by DoD. This case study provides details on how this approach is being used successfully for aerospace fasteners. 


\begin{abstract}
Case Study \# 2
Speaker: $\quad$ Howard Bloom, Deputy Director, Manufacturing Engineering Laboratory, National Institute of Standards and Technology Clearly, computerization has become a major driver of technology. One emerging standard relevant to computerization is the national effort called the Product Data Exchange Standard (PDES) or STEP (in the International Standards arena.) The standard is for exchange of unequivocal concepts taken bitewise and in a relatively well-confined context. PDES/STEP does this by providing both national and international agreed-upon (consensus) meaning and structure to the data when exchanged among computer systems. The development of this standard and how it is used by various industrial sectors will be the topic of this discussion. The Standards Development Organization providing the forum for this case study is the IGES/PDES Organization (IPO).
\end{abstract}

\title{
12:45 p.m. Question \& answer session for Procurement Panel
}

12:50 p.m. Lunch (Exhibits/networking opportunities)

\section{2:00 p.m. National Strategic Standards Panel}

\section{Moderator: Richard Serbu, Manager, Technical Standards Program} Case Study \#1

Speaker: Michael Schagrin, Standards Program Manager, Intelligent Transportation Systems Joint Program Office, DOT

The key to achieving widespread interoperability among the Intelligent Transportation System (ITS) services is through the implementation of robust non-proprietary standards. The U.S. Department of Transportation's (US DOT) ITS Joint Program Office is supporting an extensive, multi-year program of accelerating such standards development to strengthen and facilitate the successful deployment of ITS, with a specific near-term focus on infrastructure. The program is supporting and accelerating the existing ITS consensus-based volunteer standards processes already underway in the U.S. The standards organizations receiving funding support as part of this activity are:

- The Society of Automotive Engineers (SAE)

- The Institute of Transportation Engineers (ITE)

- The Institute of Electrical and Electronics Engineers (IEEE)

- The American Association of State Highway and Transportation Officials (AASHTO)

- The American Society for Testing \& Materials (ASTM) 


\section{Case Study \# 2}

Speaker: $\quad$ Dr. Michael Fitzmaurice, Director, Center for Information Technology, Agency for Health Care, Policy and Research, Health and Human Services (HHS)

The Health Insurance Portability and Accountability Act of 1996 includes a provision to develop standards that will reduce the costs and administrative burdens of health care by making possible the standardized, electronic transmission of certain administrative and financial transactions, currently carried out manually on paper. This presentation will address how the Department of Health and Human Services is working with a variety of ANSI accredited voluntary standards organizations to develop needed standards. The Standards Development Organizations providing the forum for this case study are ANSI X12, ASTM, IEEE, HL7 \& others.

\section{Case Study \#3}

Speakers: Donald Marlowe, Director, Office of Science and Technology, Center for Devices and Radiological Health, Food and Drug Administration (FDA), and Dr. Gary Fischman, Center for Devices and Radiological Health, FDA

The Food and Drug Administration has been developing a new model for standards development within the organization. The extent of standards development efforts, the current standards development model, and a case study of how standards works at the FDA will be given. The Standards Development Organization providing the forum for this case study is ASTM.

\section{2:45 p.m. Question \& answer session for Strategic Standards Panel}

3:00 p.m. Break (Exhibits/networking opportunities)

3:30 p.m. Issues - future actions

Dr. Belinda Collins, Director, Office of Standards Services

4:00 p.m. Wrapup - Adjourn

Dr. Belinda Collins, Director, Office of Standards Services 
Section 1

\section{P.L. 104-113 \\ Federal Use of Voluntary Standards}



PL 104-113

Federal Use of

Voluntary Standards

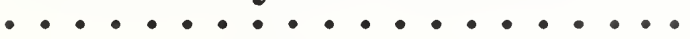

Belinda L. Collins

Office of Standards Services

\section{Public Law Directs that:}

- Federal Agencies shall rely on voluntary standards to the extent practicable for regulatory and procurement purposes

- identify agency needs and applicable voluntary standards

- participate in development of voluntary standards

- NIST shall coordinate with Federal, state and local agencies and with private sector on standards and conformity assessment activities

- NIST submitted Implementation Plan to Congress

\section{Background}

$\bullet \cdot \bullet \bullet \bullet \bullet \bullet \bullet \bullet \bullet \bullet \bullet \bullet \bullet \bullet \bullet \bullet \bullet \bullet \bullet \bullet \bullet$

- NRC Report on Standards, Conformity Assessment and Trade for the 21st Century

- U.S. standards and conformity activities are decentralized, often competitive, and a mixture of public and private activities.

- Increases product cost, time to market, wastes staff resources, and hinders exports

- Need for national infrastructures for standards and conformity assessment to support global trade

\section{New NIST Responsibilities}

- • • • • • • • • • • • • • • • •

- Assist agencies in developing and implementing policy and procedures for using voluntary standards and participating in their development

- Identify policy issues and work through the ICSP to resolve

- Develop effective strategies for collaboration between government agencies and private sector

- Continue traditional technical and policy roles in standards and conformity assessment

\section{NIST Responsibilities}

- Cooperate with OMB and ICSP members

- Assist in revision of OMB Circular A-119

- Chair Interagency Committee on Standards Policy

- Provide assistance and leadership for Federal Agencies

- Report annually on use of private sector voluntary standards, development of any new agency specific standards, and agency participation in voluntary standards activities

- Report through OMB to Congress

\section{Federal Agencies}

- ICSP now intensifying coordination

- Agencies to identify specific issues related to use of voluntary standards and participation in process

- Implement a strategic standards policy for use of voluntary standards

- Develop internal processes for committing resources and staff, as well as monitoring policy issues

- NIST with ICSP to develop procedures for coordination within and among agencies 


$$
\text { - }
$$

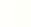

(1)

(2)

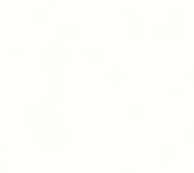

(2)

$$
\text { (1) }
$$

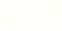

$$
\text { (2) }
$$

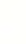

(1)

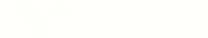

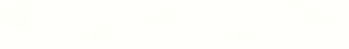

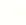

(1)

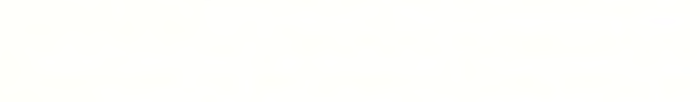$$
\text { (1) }
$$$$
\text { - }
$$ 


\section{Federal Agencies and NIST will:}

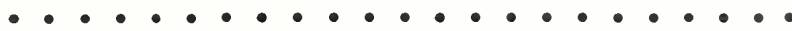

- Work with ANSI and standards developing organizations (SDOs) to address:

- proliferation and overlap of standards

- speed of standards development

- effective use of standards by Federal agencies

- Work on policies for licensing standards

- Develop procedures for timely notification to Federal agencies of proposed new standards

- Develop mechanisms for coordinating with ANSI and other SDOs on international standards issues

- Enhance collaborative efforts on standards and conformity assessment

\section{NIST Activities}

- Work with state and local agencies to develop procedures for implementing standards and conformity assessment activities

- Develop strategies for coordination with Federal and private sector activities

- Work with representatives of building Code organizations to develop policies for standards and conformity assessment for Federal and local use

\section{Conformity Assessment}

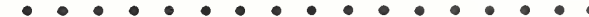

- Includes product certification, accreditation of testing and calibration laboratories, and management system registration (quality and environment)

- U.S. must develop national strategies for coordinated systems for conformity assessment

- NIST will perform policy analysis of costs of duplication to government agencies and industry

- NIST will work with private sector conformity assessment bodies to obtain international acceptance

- All must work together to facilitate goal of one product, one standard, and one test, with worldwide acceptance

\section{Management System Standards}

- Agencies to work through Government Industry Quality Liaison Panel (GIQLP) to ensure use of ONE quality system per supplier to the Federal government

- Develop procedures to recognize competence of each others' quality system audits

\section{Laboratory Accreditation}

- NIST working with private sector and other government agencies to establish infrastructure for coordinating activities in laboratory accreditation

- Successful Public Forum on National Council for Laboratory Accreditation (NACLA) on Jan 7, 1997

- Consensus on structural approach for NACLA

- NIST will continue National Voluntary Laboratory Accreditation Program

- Accredit calibration laboratories to ensure necessary traceability to national standards

- Accredit testing laboratories as mandated by Congress or requested by other Federal Agencies

\section{Conclusions -} NIST Policy Activities

- NIST is implementing Plan to increase coordination among Federal agencies

- Provide assistance in use of voluntary standards

- Coordinating activities with ANSI, SDOs, Federal, state and local agencies to build workable systems for standards and conformity assessment to meet the needs of U.S. industry in a global market 



\section{Conclusions - Continued NIST Policy Activities}

- Lead ICSP as a viable and effective forum for coordinating Federal efforts, and for encouraging agency use of voluntary standards

- Work effectively with state and local authorities

- Work vigorously to achieve the goal of national systems for conformity assessment that will be accepted domestically and internationally

\section{Planned Collaborative Activities}

$\therefore$ Open Forum on Laboratory Accreditation

- Workshop on effective Federal participation in and use of standards

- Training opportunities on process and procedures

- Policy discussions in ICSP on key issues

- Continuing support for GIQLP activities

- Continuing support for task forces on Federal uses of ISO 14000,9000 , laboratory accreditation, information resources, and strategic standards management

- Continue to solicit ideas for cooperation and collaboration between public and private sector 

Section 2

The ANSI Role 



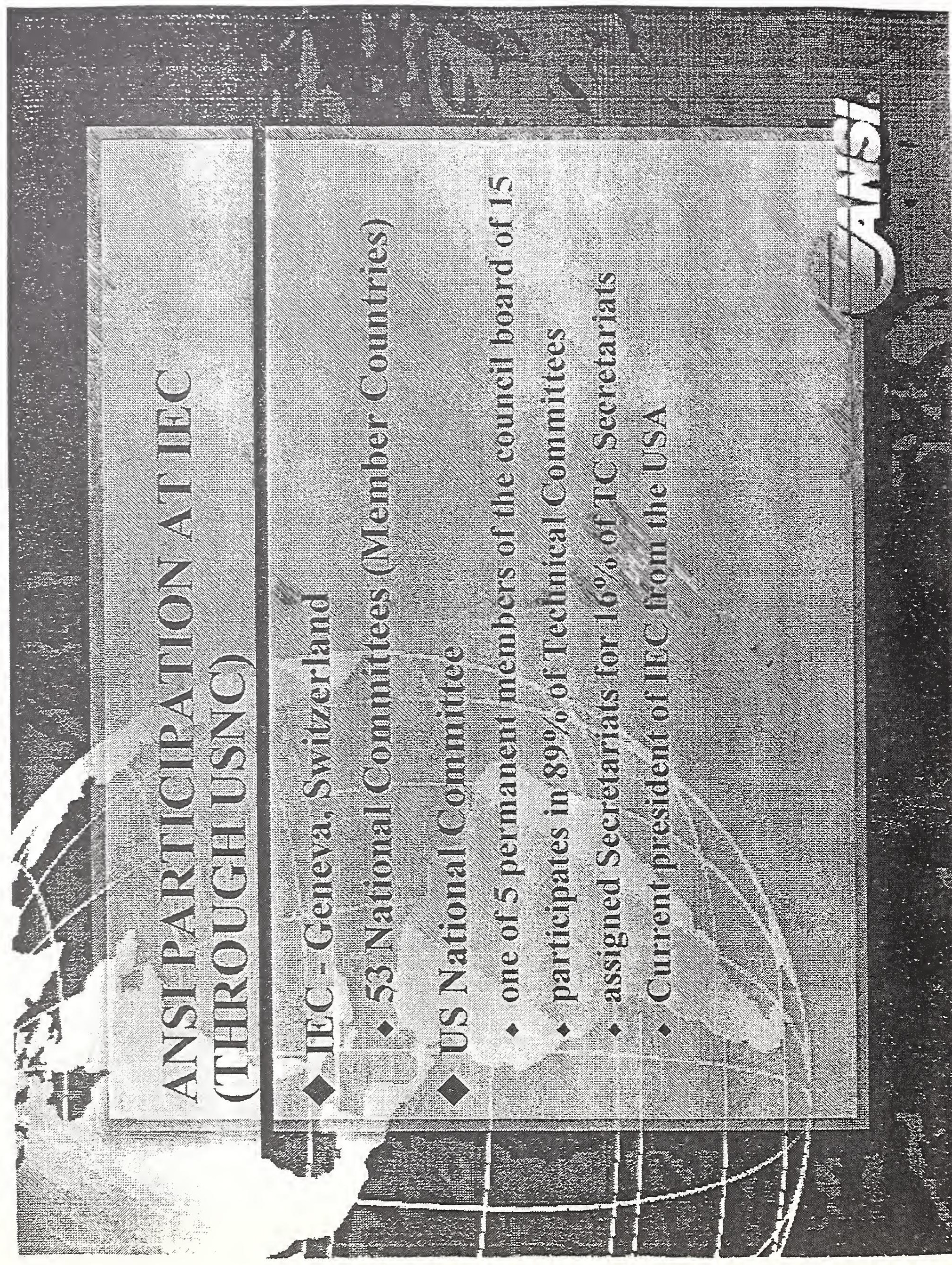




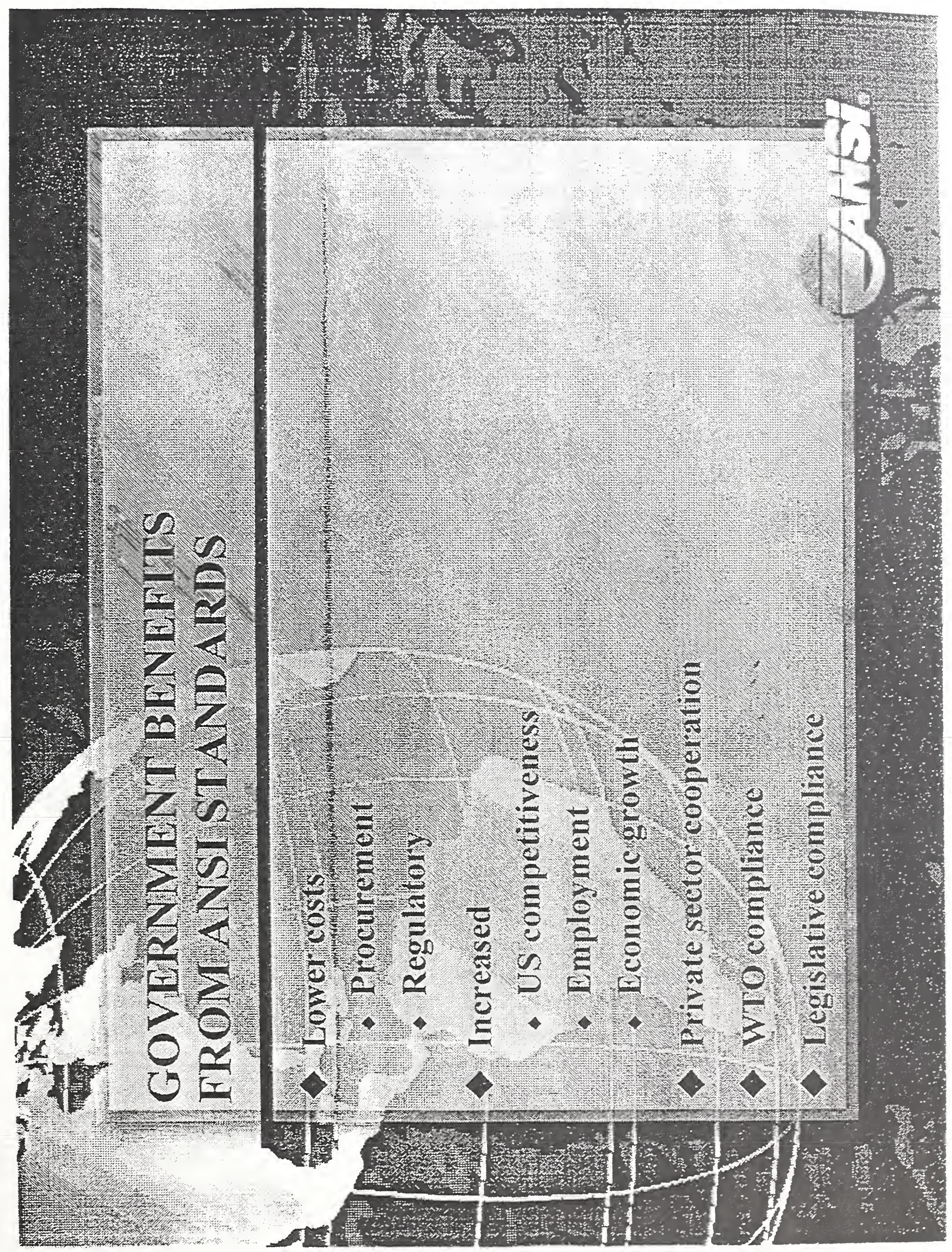




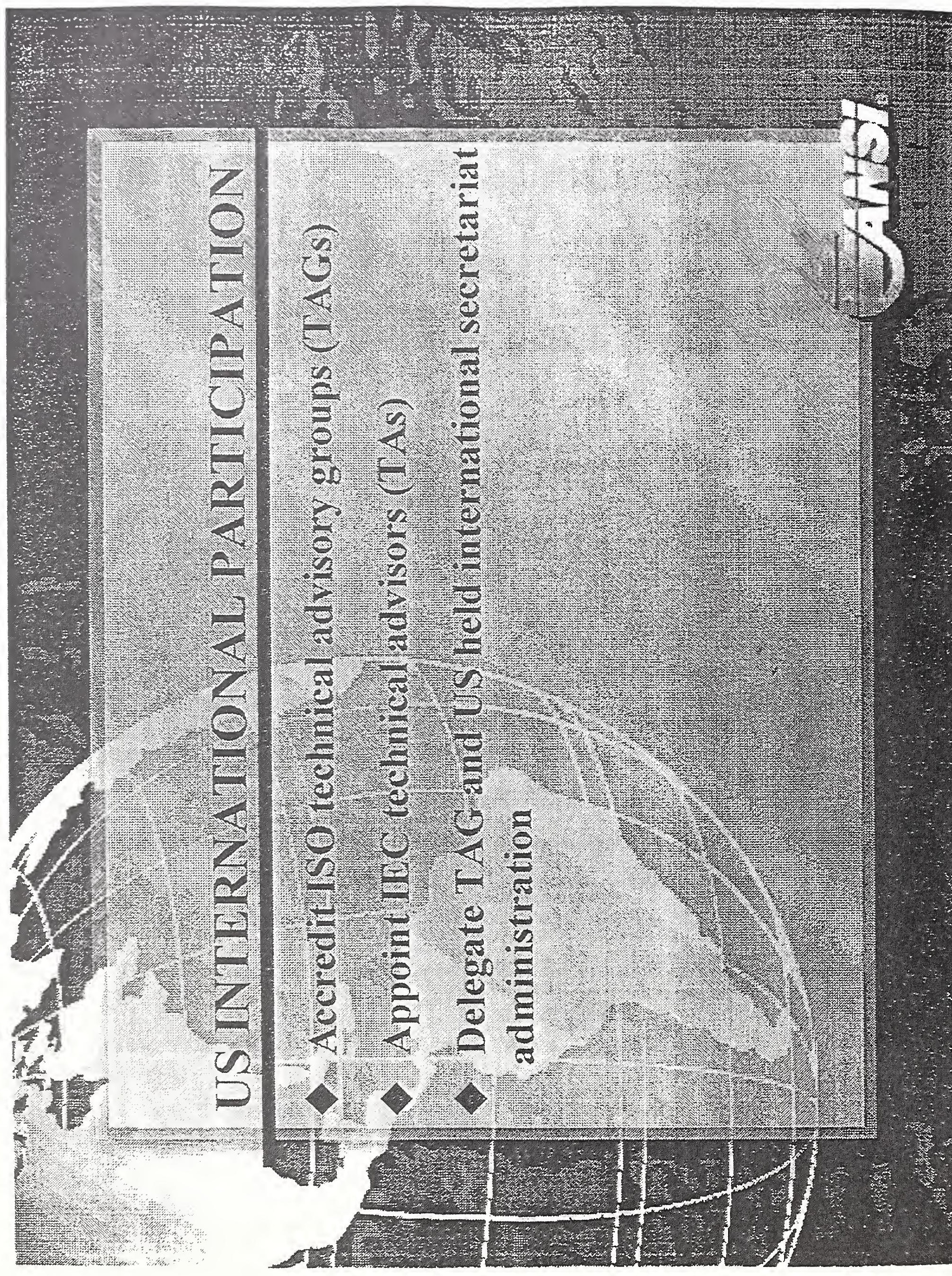




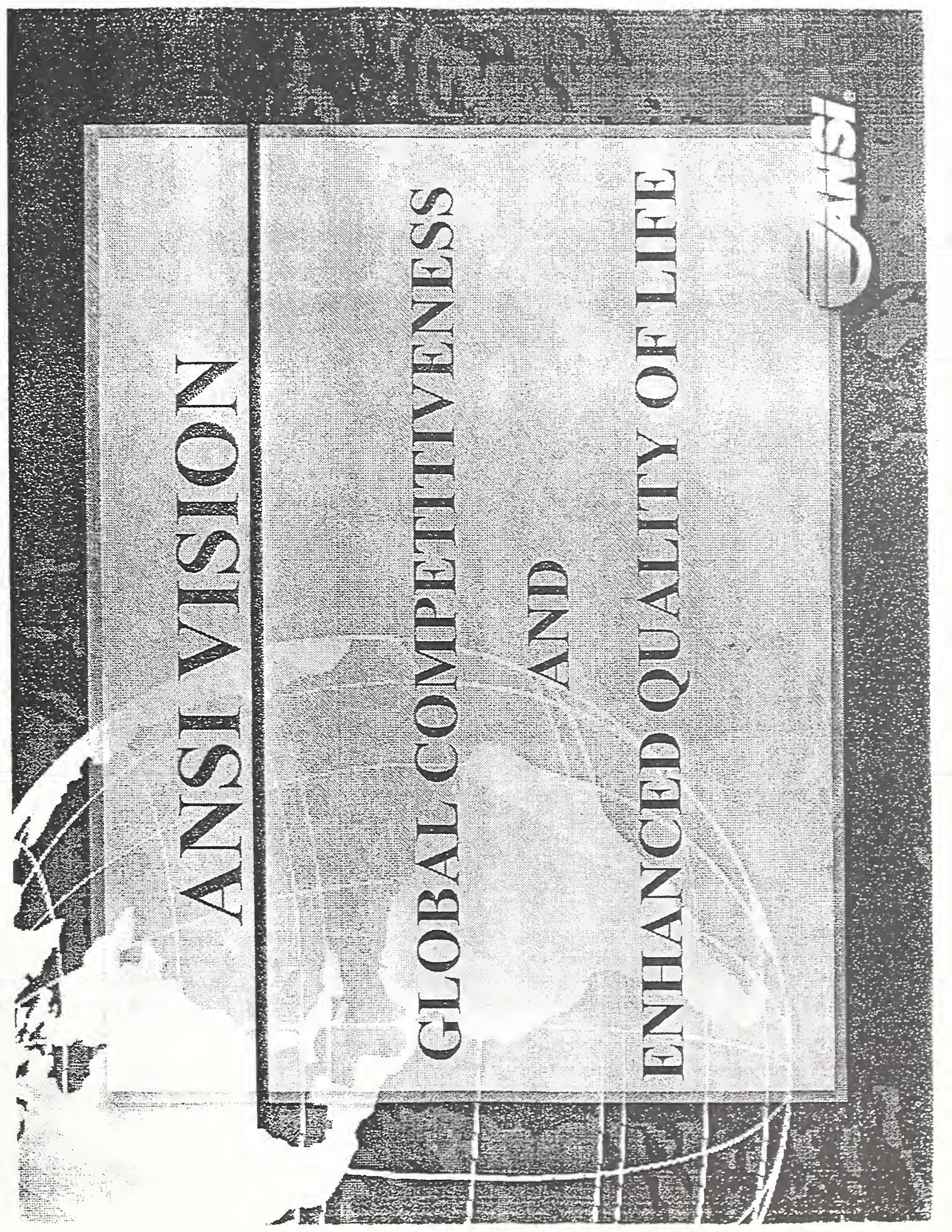




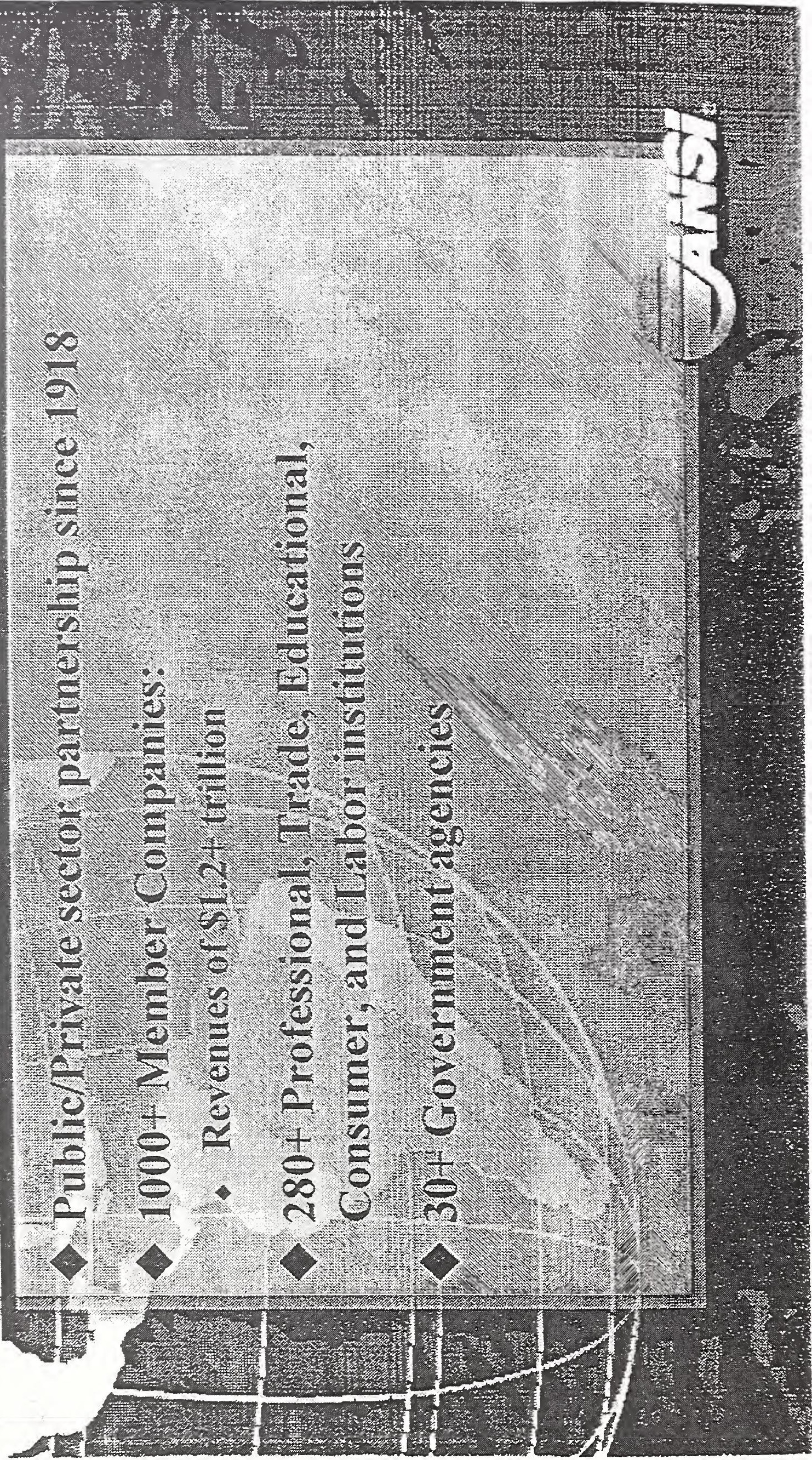




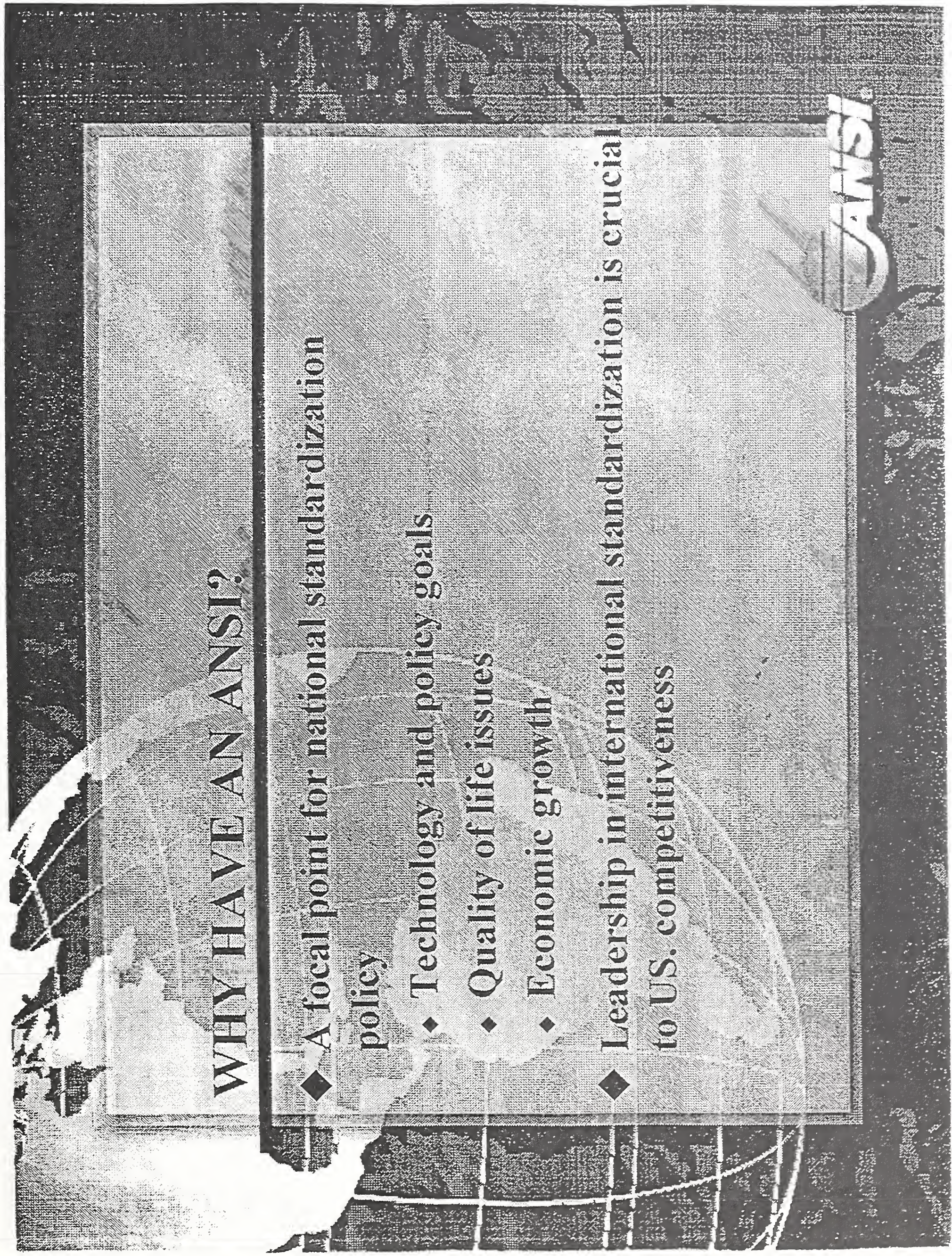




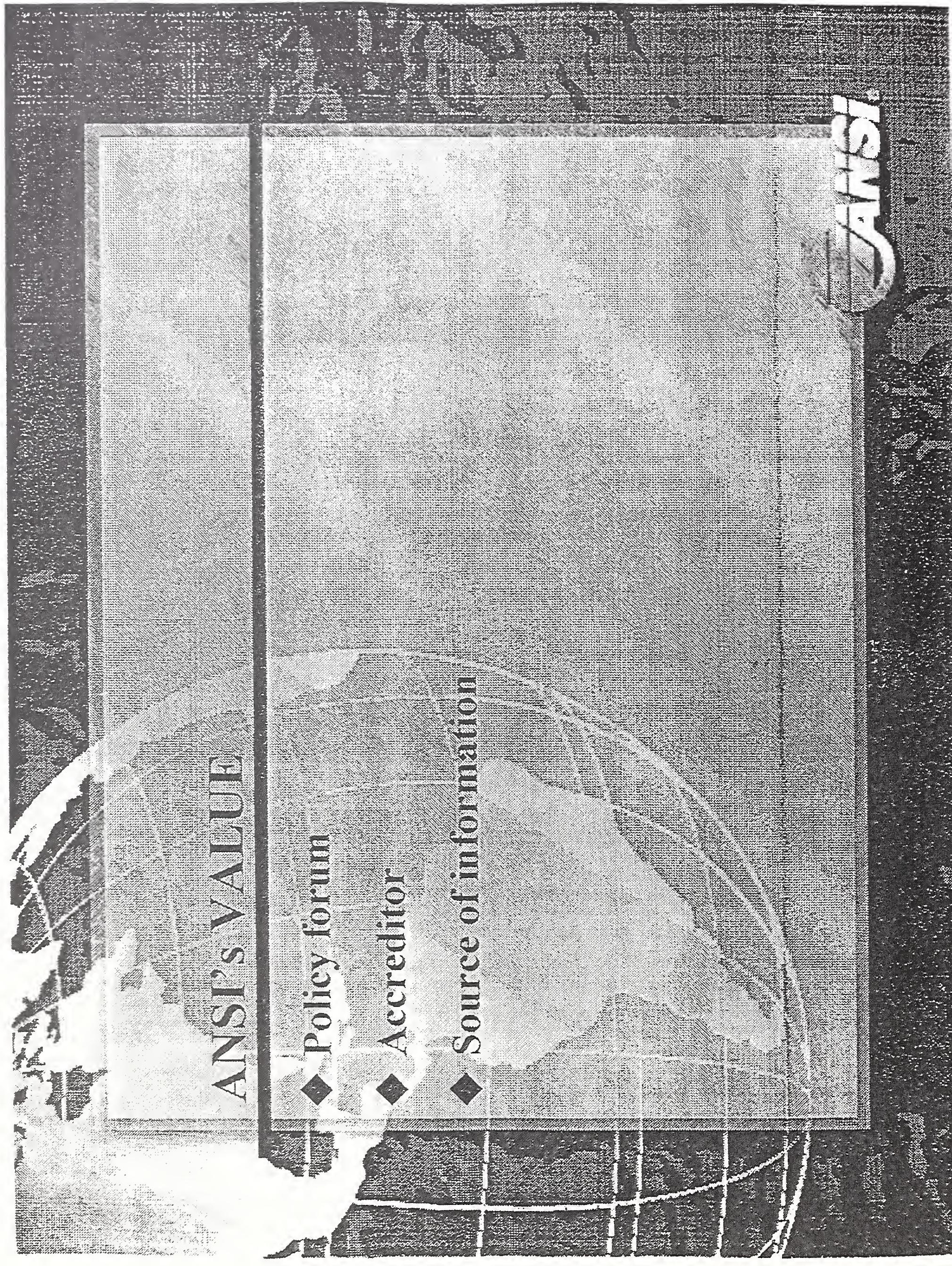




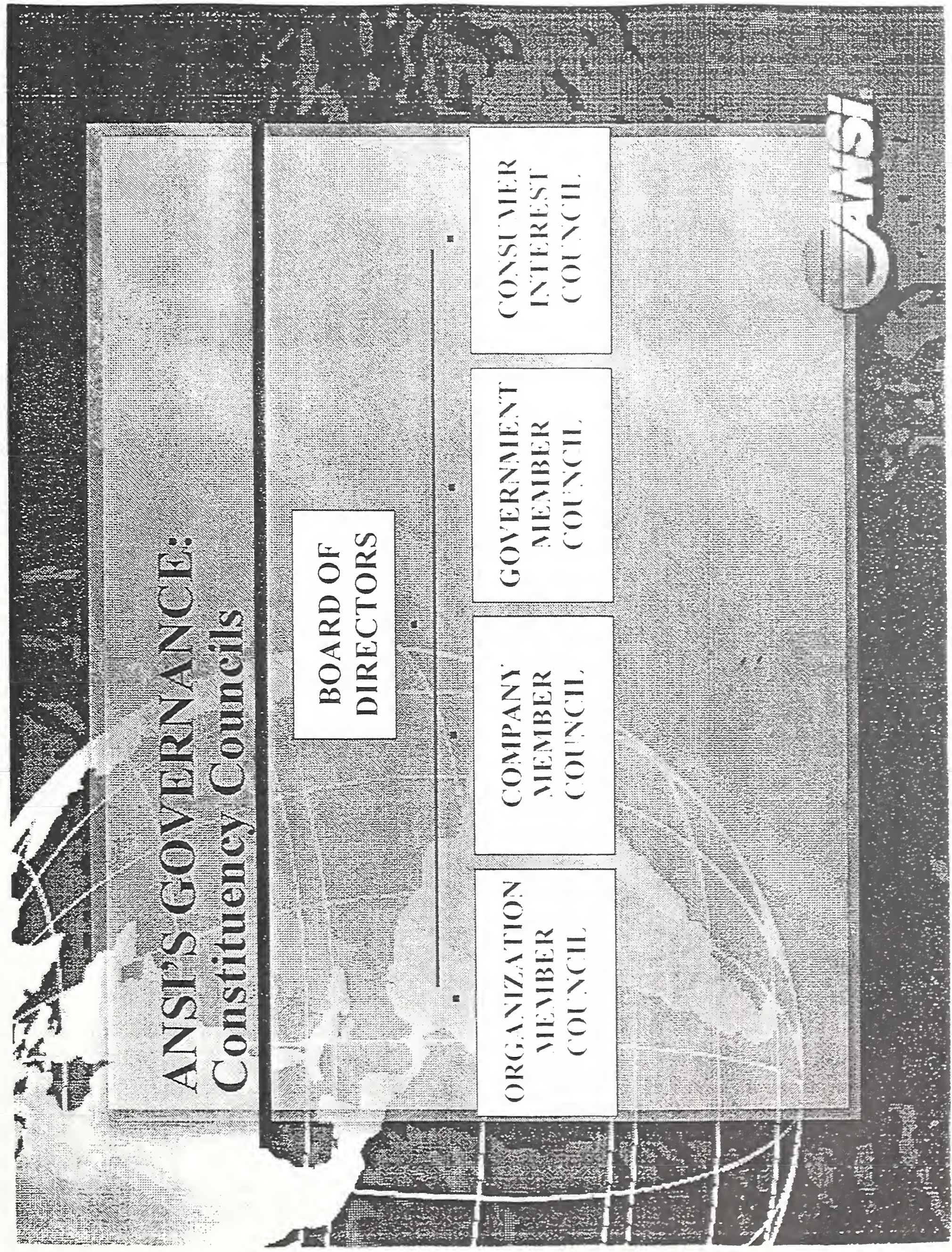




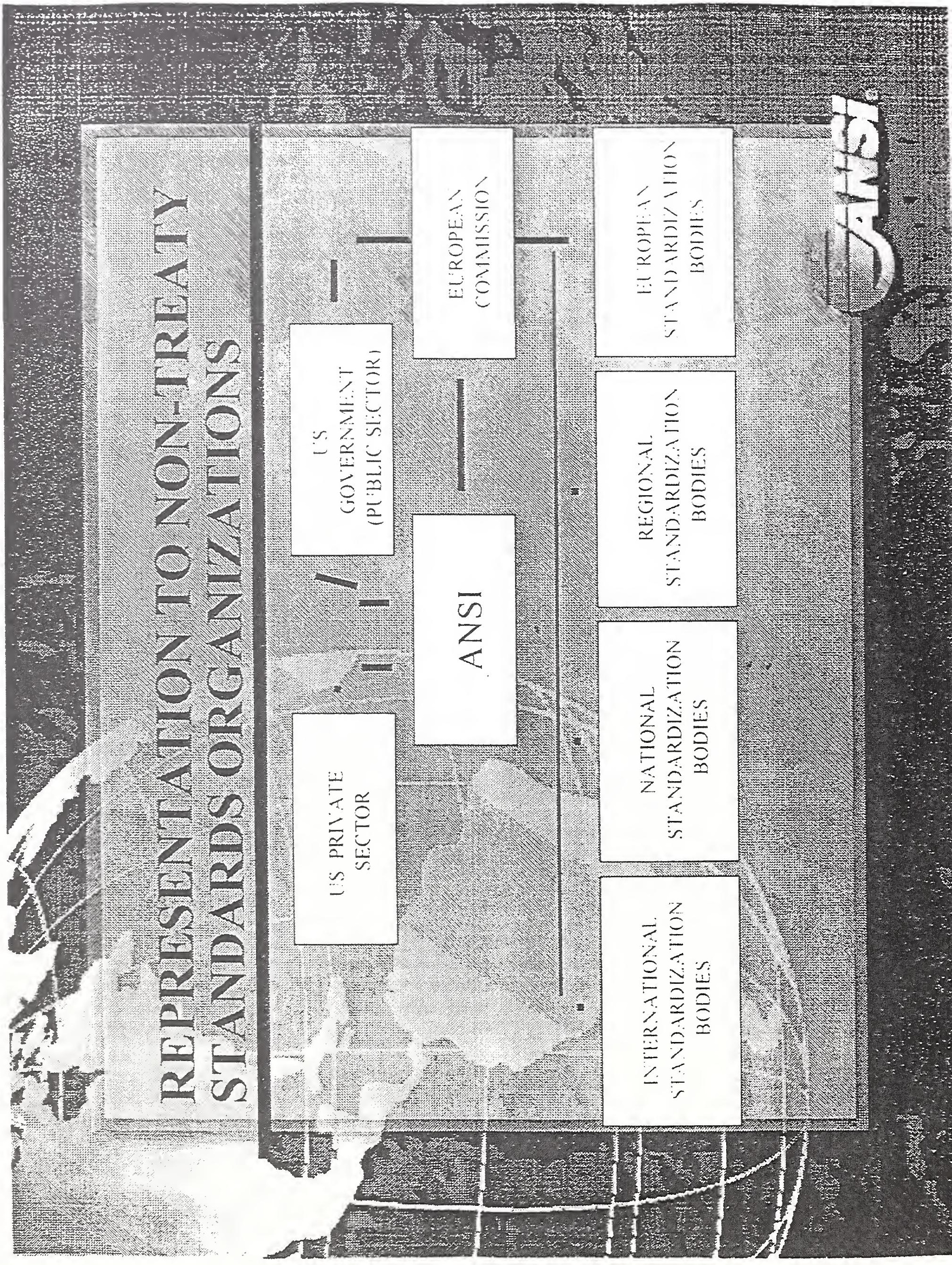




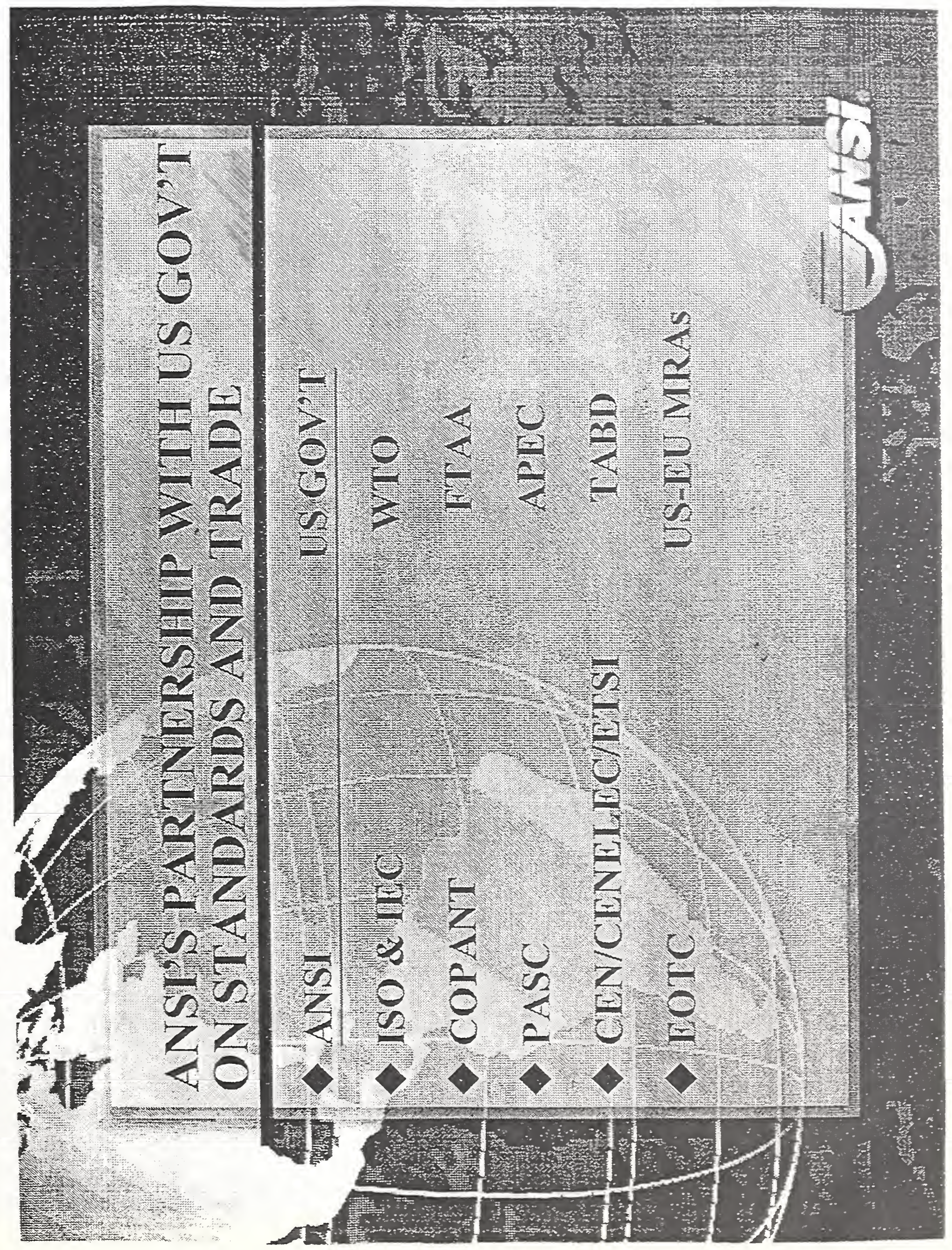




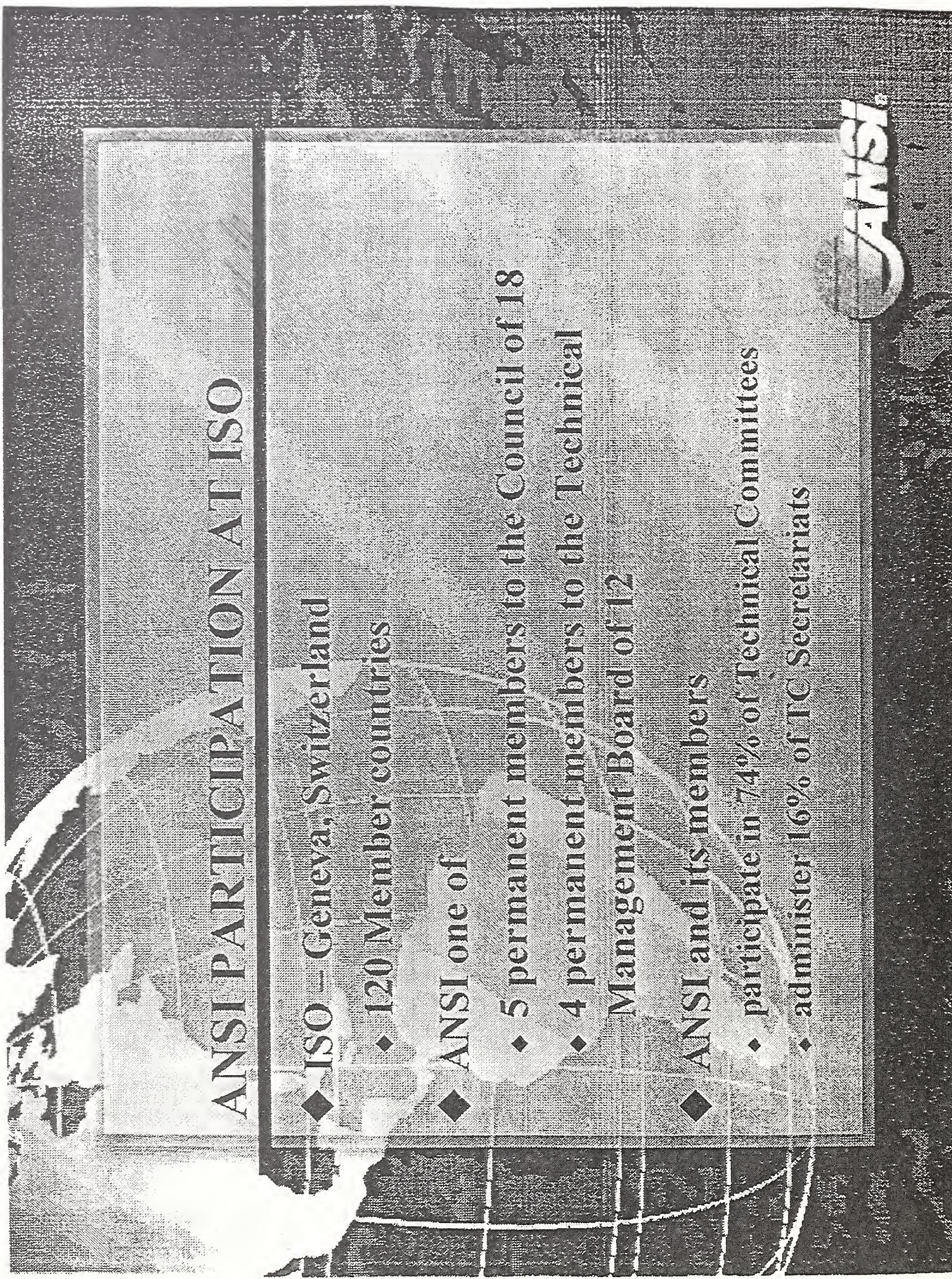


Section 3

Regulatory Standards Panel on

\section{Health and Safety}




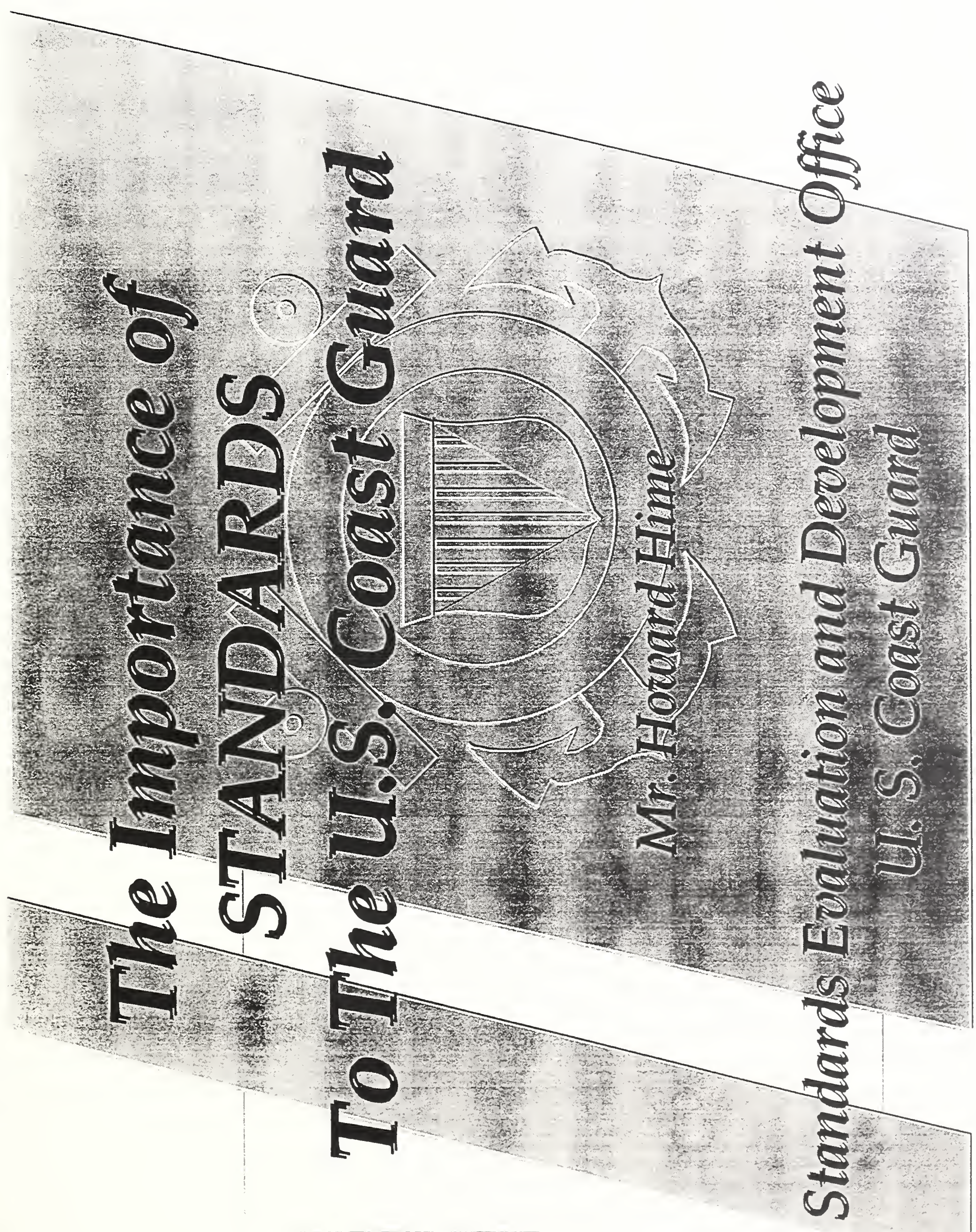




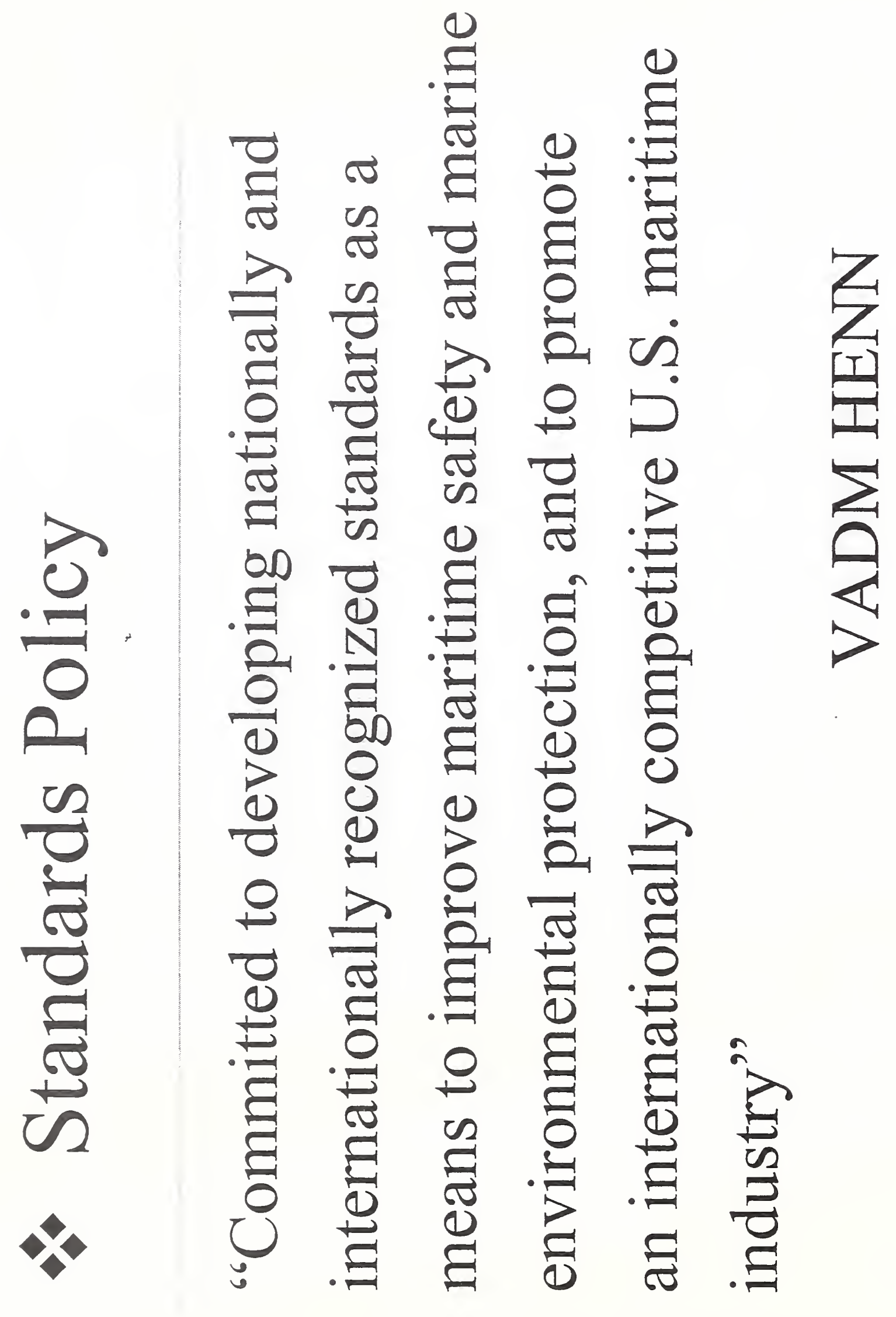



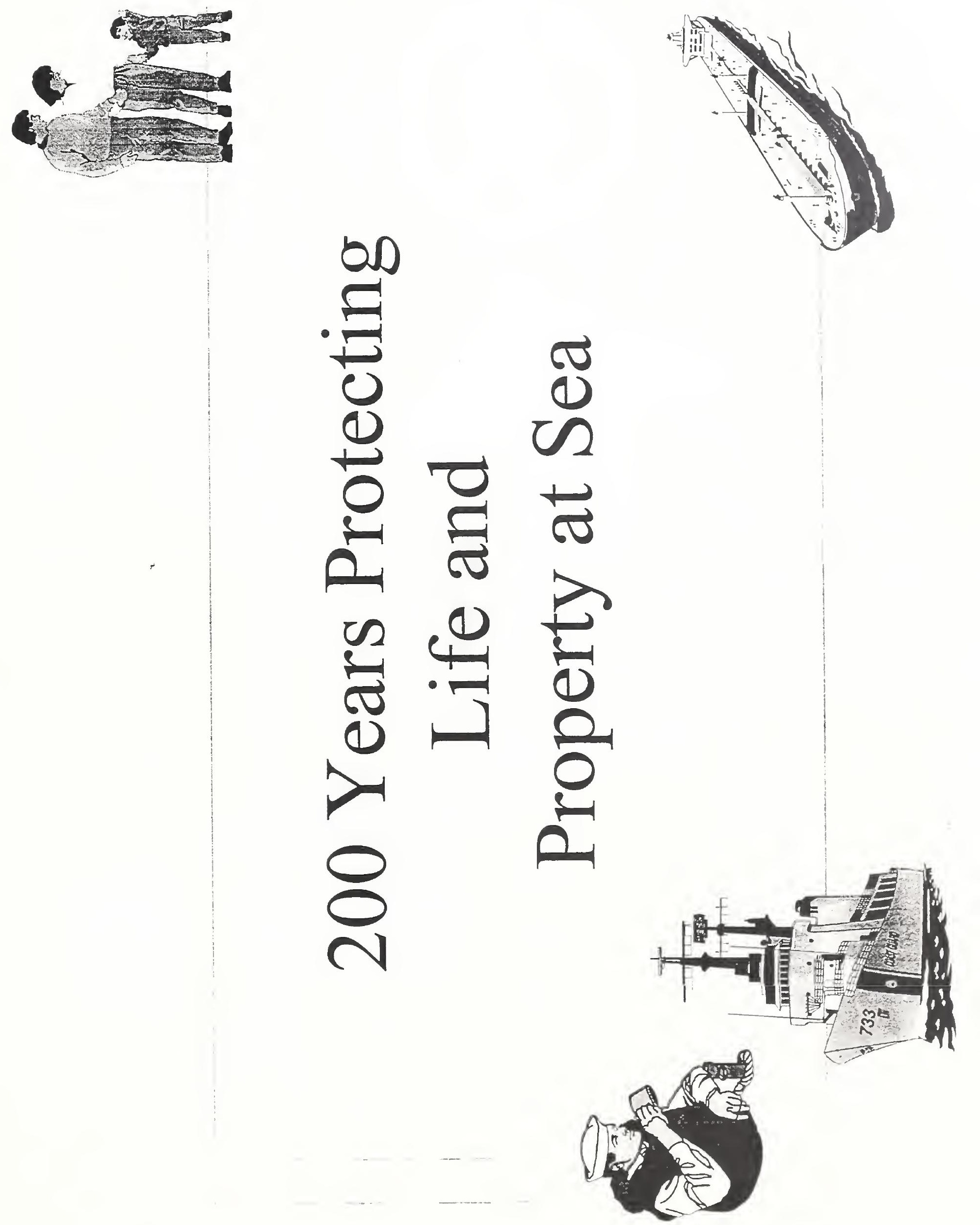


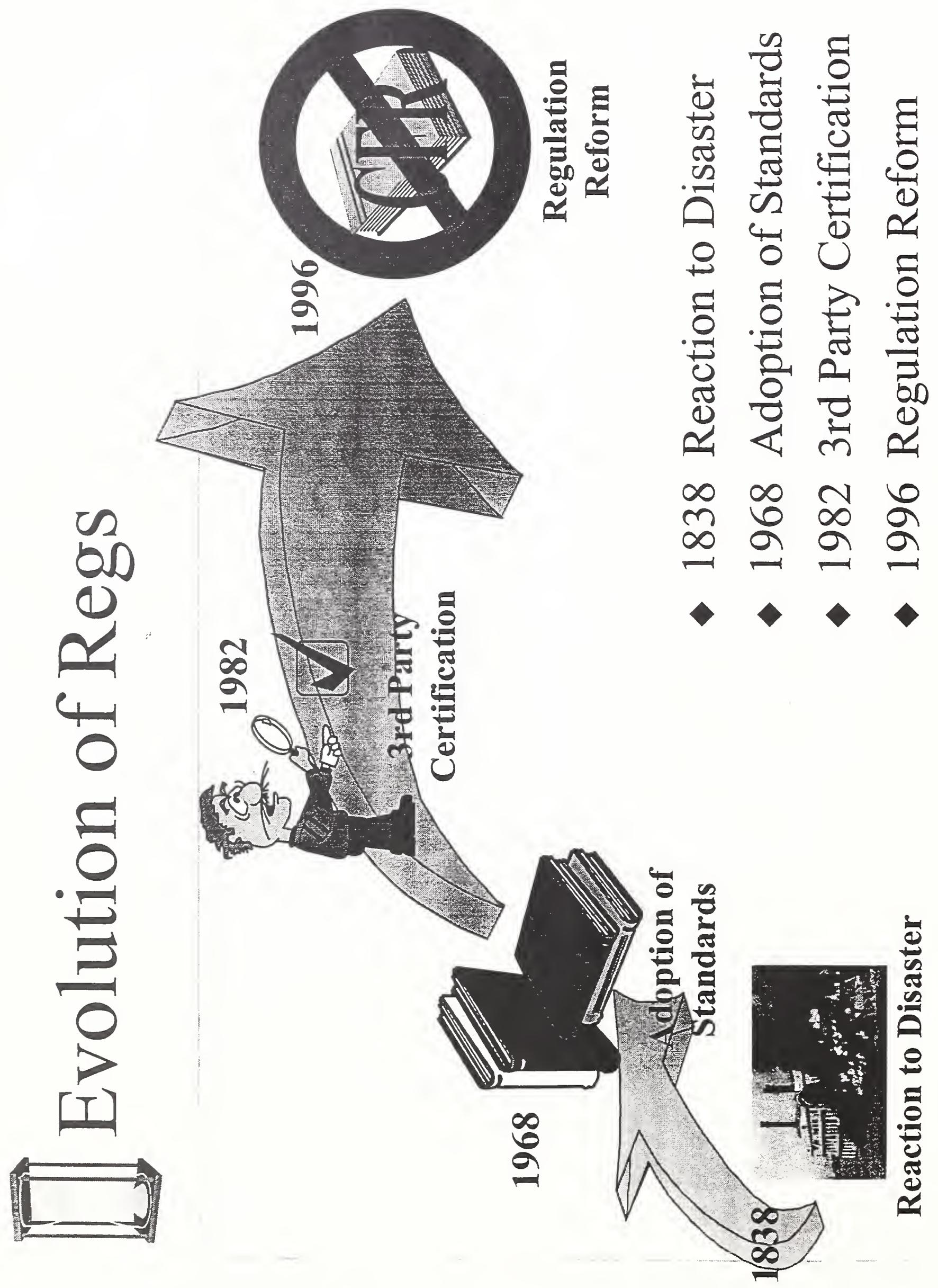




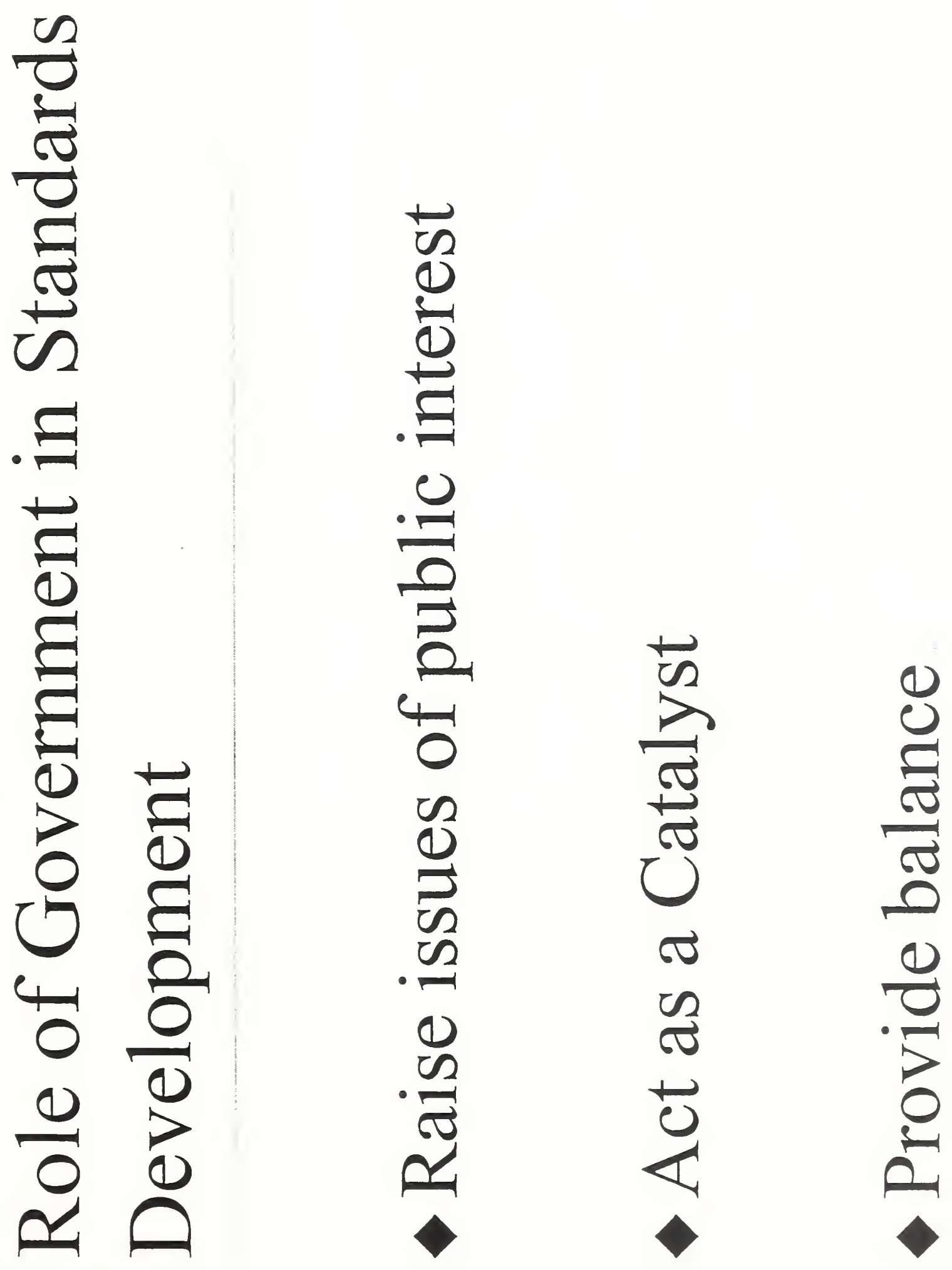




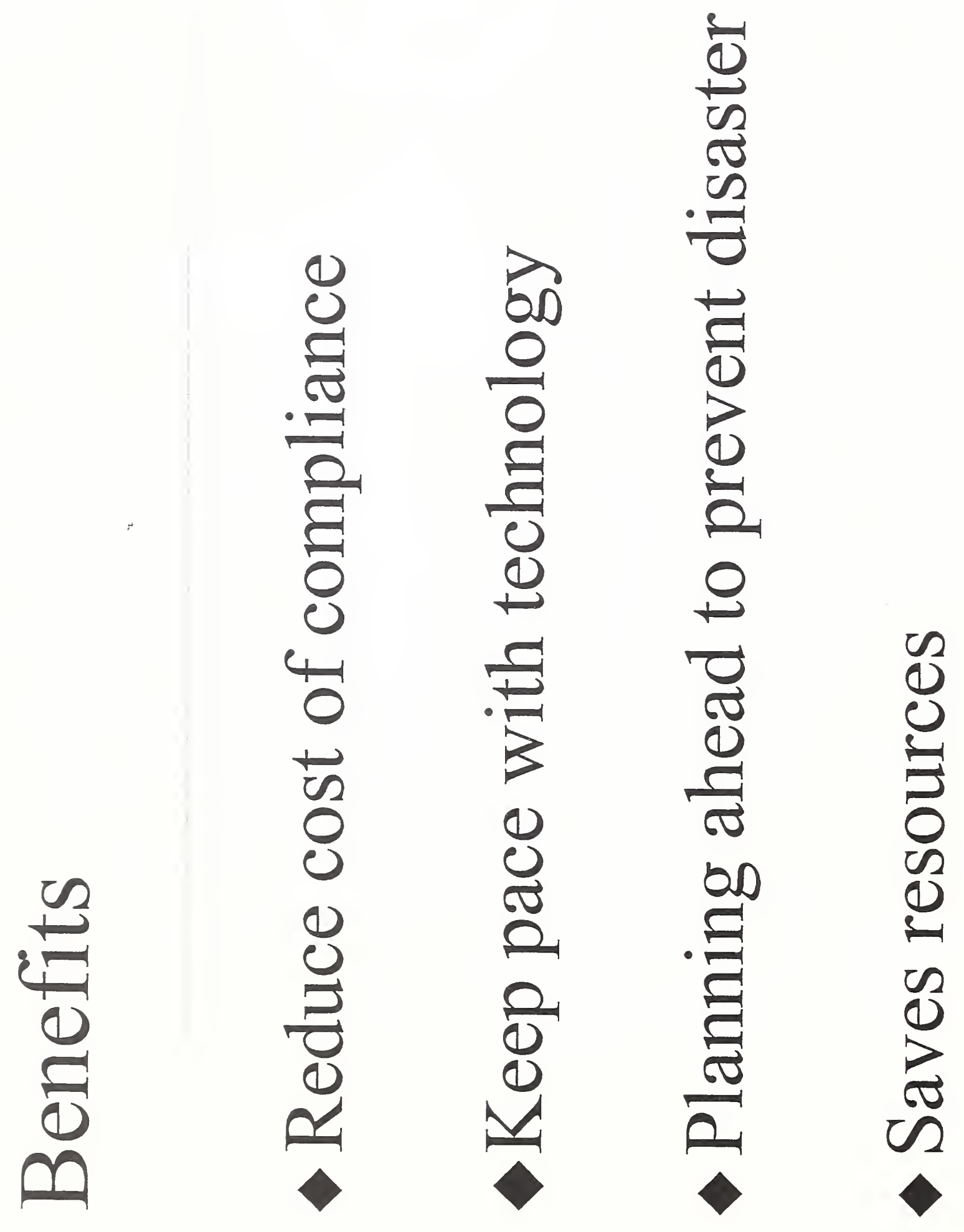




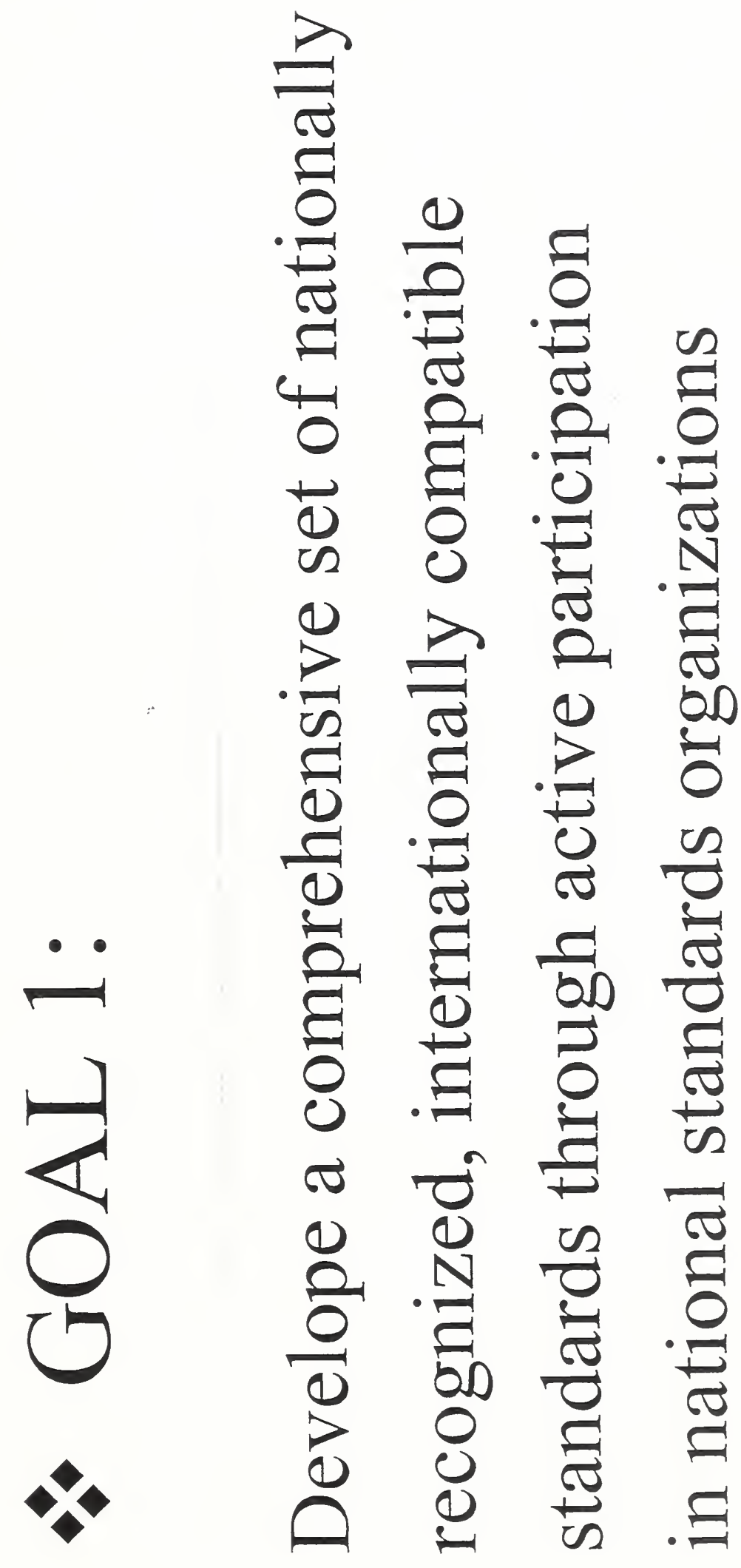




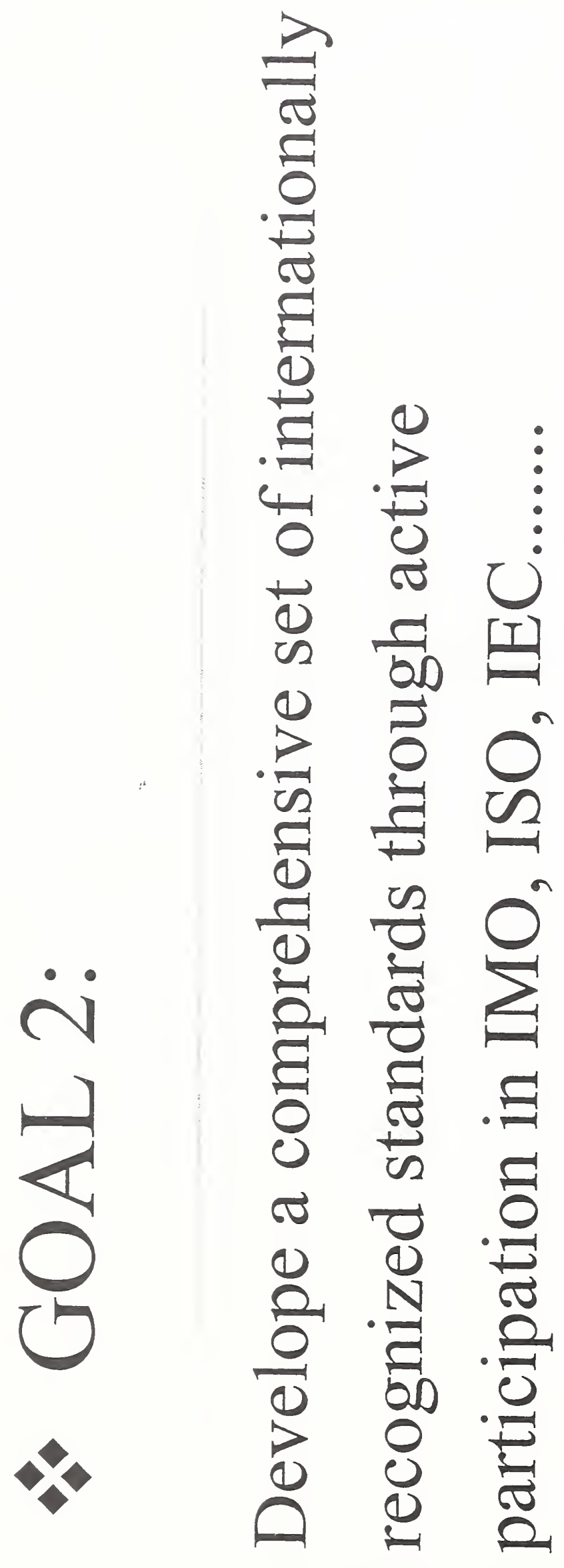




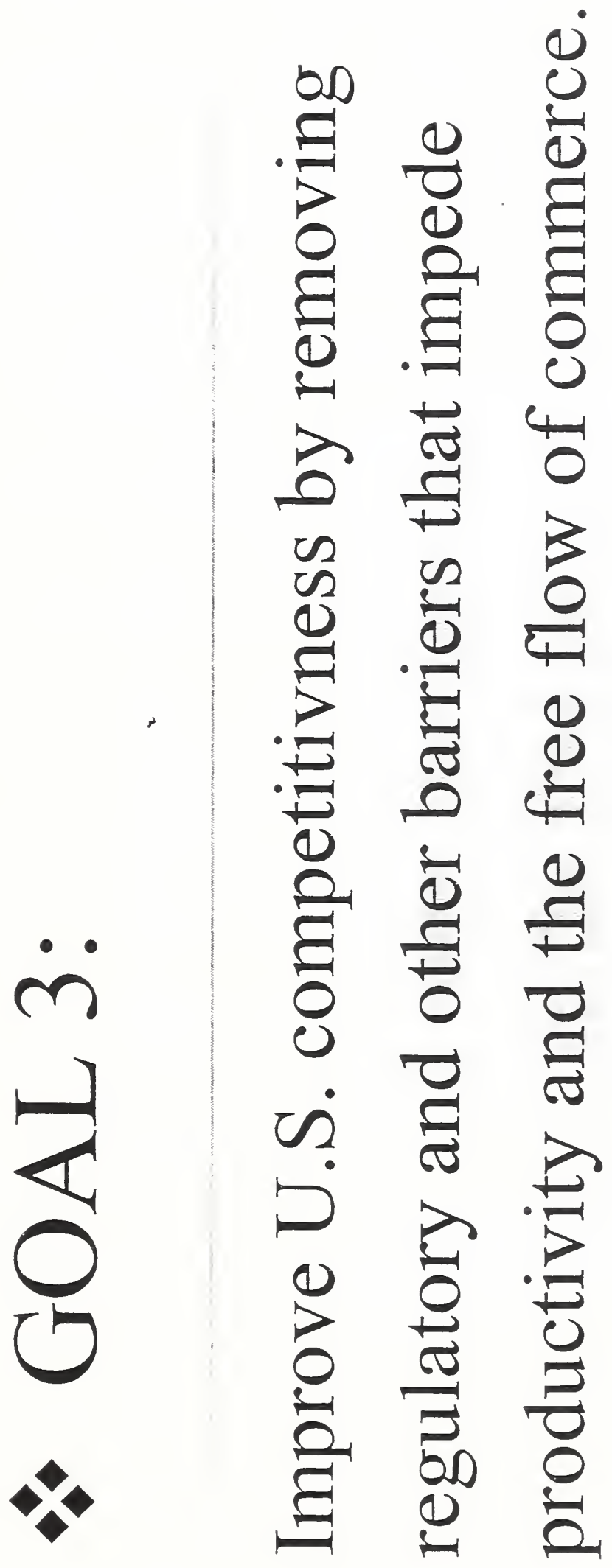



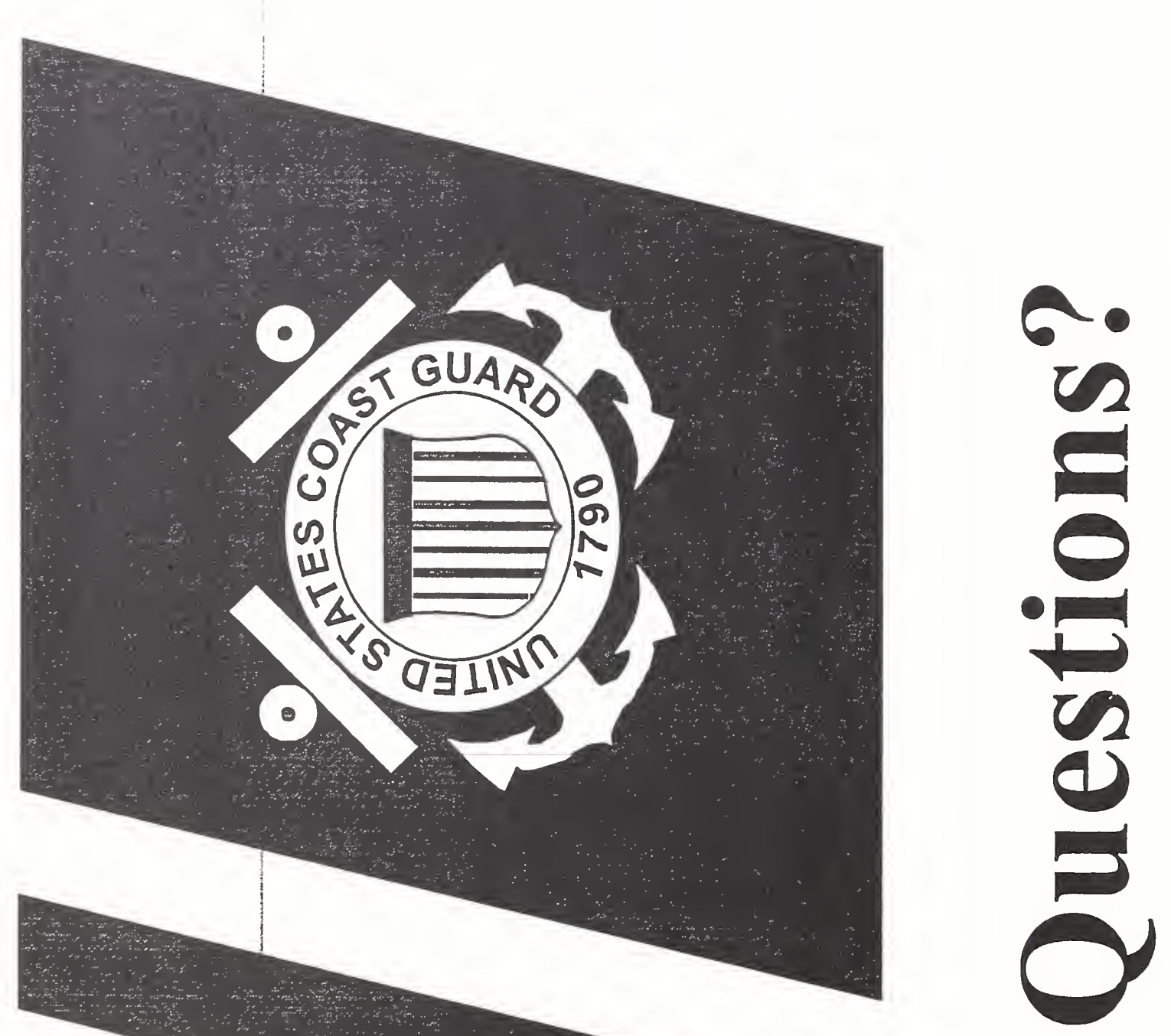
Slide 1 The Importance of Standards to the CG

THANK YOU FOR GIVING ME THE OPPORTUNITY TO SPEAK WITH YOU TODAY ABOUT MY FAVORITE SUBJECT - STANDARDS AND THEIR IMPORTANCE TO THE COAST GUARD. STANDARDS ARE A KEY ELEMENT OF THE COAST GUARD'S STRATEGIC PLAN FOR MARITIME REGULATORY REFORM. LET ME STATE FROM THE OUTSET--THE CG TAKES A PROACTIVE POSITION REGARDING STANDARDS.

THIS POSITION WAS REAFFIRMED WHEN VADM HENN SIGNED A COMDTINST OUTLINING THE POLICY AND GOALS OF THE STDS PROGRAM FOR OUR MARINE SAFETY AND ENVIRONMENTAL PROTECTION PROGRAMS.

\section{Slide 2 Policy}

IN THIS COMDTINST, VADM HENN STATES:

THE USCG IS COMMITTED TO DEVELOPING NATIONALLY AND INTERNATIONALLY RECOGNIZED STANDARDS AS A MEANS TO IMPROVE MARITIME SAFETY AND MARINE ENVIRONMENTAL PROTECTION, AND TO PROMOTE AN INTERNATIONALLY COMPETITIVE U.S. MARITIME INDUSTRY.

THE COAST GUARD WILL CONTINUE TO STRIVE FOR A SAFE MERCHANT MARINE. HOWEVER, SAFETY MUST BE COST EFFECTIVE. IN DEVELOPING STANDARDS, OUR GOAL IS NOT ONLY TO INSURE SAFETY BUT TO ENSURE THAT THE STANDARDS DEVELOPED DO NOT PUT U.S. INDUSTRY AT A COMPETITIVE DISADVANTAGE. 
Slide 3200 years protecting life and property at sea

FOR OVER TWO CENTURIES THE COAST GUARD HAS BEEN RESPONSIBLE FOR THE PROTECTION OF LIFE AND PROPERTY AT SEA. THE USCG IS CHARGED WITH DIRECTING A COORDINATED FEDERAL PROGRAM FOR COMMERCIAL VESSEL SAFETY, PORT SAFETY, SECURITY, AND ENVIRONMENTAL PROTECTION. IN ORDER TO MEET THIS MANDATE THE COAST GUARD IS RESPONSIBLE FOR, ENFORCING APPLICABLE FEDERAL LAWS, DEVELOPING REGULATIONS NECESSARY FOR MMPLEMENTING THESE LAWS, NEGOTIATING AND ENFORCING INTERNATIONAL TREATIES, AND REPRESENTING THE UNITED STATES AND COAST GUARD INTERESTS IN NATIONAL AND INTERNATIONAL FORA. 
Slide 4 Evolution of Regs

HISTORICALLY, THE REGULATORY PROCESS FOR MARINE SAFETY HAS BEEN CHARACTERIZED BY RESPONSE TO DISASTER. THE ADVENT OF STEAM PROPULSION IN THE EARLY 1800'S BROUGHT NUMEROUS SHIPBOARD BOILER EXPLOSIONS WITH TRAGIC LOSS OF LIFE. WITH PUBLIC CONCERN AT A HIGH LEVEL, CONGRESS TOOK ACTION BY PASSING THE STEAMBOAT INSPECTION ACT OF 1838 AND A SERIES OF OTHER LAWS WHICH RESULTED IN REGULATIONS AIMED AT REDUCING THE NUMBER OF SHIPBOARD EXPLOSIONS AND RESULTANT FATALITITES. THE SINKING OF THE TITANIC WITH ITS HEAVY LOSS OF LIFE POINTED OUT THE NEED FOR IMPROVED LIFESAVING CAPABILITIES AND IMPROVED STABILITY AND WATERTIGHT SUBDIVISION REQUIREMENTS. AGAIN, PUBLIC CONCERN STIMULATED CONGRESSIONAL ACTION WHICH RESULTED IN ADDITIONAL REGULATIONS. THE BURNING OF THE MORRO CASTLE, AGAIN WITH SIGNIFICANT LOSS OF LIFE, BROUGHT ABOUT IMPROVED FIRE PROTECTION REGULATIONS.

EACH OF THESE MARINE DISASTERS RESULTED IN THE PUBLICATION OF COMPRESHENSIVE REGULATIONS TO ADDRESS THE HAZARD AND MINIMIZE ITS RECURRENCE.

EARLIER REGULATORY EFFORTS WERE VERY DETAILED, AS THE VOLUNTARY STANDARDS MOVEMENT HAD ONLY BEGUN TO DEVELOP. IN THE ABSENCE OF A BROAD BASE OF INDUSTRY GENERATED STANDARDS, EXTENSIVE AND DETAILED REGULATIONS WERE DRAFTED AND ENFORCED. THE EXPANSION OF TRADE HORIZONS AND VARIATIONS IN 
THE SAFETY STANDARDS IMPOSED BY JURISDICATIONS HELPED

ADVANCE THE CONCEPT OF VOLUNTARY STANDARDIZATION. AS THE CONCEPT EVOLVED, MANY OF THESE VOLUNTARY STANDARDS GAINED ACCEPTANCE AS “NATIONAL” STANDARDS AND BECAME SUITABLE FOR INCORPORATION IN FEDERAL REGULATIONS. IN OTHER CASES, EXISTING DETAILED REGULATIONS FORMED THE BASIS FOR DEVELOPING A VOLUNTARY STANDARD.

IN EARLIER EFFORTS TO INCORPORATE VOLUNTARY STANDARDS, ADMINISTRATIVE PROCEDURES DICTATED THAT THEY BE REPRODUCED IN PART OR IN FULL AS REGULATIONS. IT WAS NOT UNTIL 1968 THAT THE CONCEPT OF INCORPORATION BY REFERENCE, WHERE A VOLUNTARY STANDARD IS INVOKED IN THE REGULATIONS AND IDENTIFIED ONLY BY NAME AND EDITION, ENABLED US TO REALIZE THE FULL BENEFIT OF USING NON-GOVENMENT STANDARDS.

EMPLOYING THIS METHOD WE ADOPTED WELL OVER 100 INDUSTRY STANDARDS IN 1968 AND CONTINUED TO ADD MORE EACH YEAR. WHILE WE ACCEPTED CERTIFYING MARKS FOR MANY PIPE AND ELECTRICAL COMPONENTS, WE RETAINED SHOP INSPECTION AND PLAN APPROVAL FOR MANY OTHERS, SUCH AS BOILERS AND PRESSURE VESSELS. IT WAS HARD FOR US TO GIVE UP PAST MEMORIES OF THE TRAGIC ACCIDENTS AND THE RESPONSIBILITIES ENTRUSTED TO US BY THE PUBLIC. HOWEVER, OVER THE ENSUING YEARS WE BECAME MORE INVOLVED WITH THE STANDARDS COMMITTEES, SUCH AS THE ASME B\&PVC. WITH EACH 
COMMITTEE WE LENT OUR EXPERIENCE IN THE FIELD OF MARINE SAFETY, ENSURING THAT THE ASSOCIATED CONCERNS ARE TAKEN INTO ACCOUNT. IN ADDITION, WE GREW MORE FAMILIAR AND CONFIDENT WITH THE DEVELOPMENT AND OPERATION OF THE STANDARDS AND BEGAN REPLACING COAST GUARD PLAN APPROVAL AND SHOP INSPECTION WITH $3^{\text {RD }}$ PARTY CERTIFICATION. OUR $1^{\text {ST }}$ MAJOR EFFORT CAME IN 1982 WHEN WE ADOPTED THE ASME CODE SYMBOL STAMP. FROM 1968 TO 1995 ALL OF THE STANDARDS WE ADOPTED WERE AMERICAN NATIONAL STANDARDS. THREE YEARS AGO WE BEGAN AN EFFORT KNOWN AS REGULATORY REFORM TO LOOK AT OUR REGULATIONS, ELIMINATE THOSE THAT WERE OUTDATED OR INEFFICIENT, AND ADOPT INTERNATIONAL STANDARDS WHERE POSSIBLE. RECENTLY WE REVISED OUR ELECTRICAL REGULATIONS ADOPTf́NG 86 NEW STANDARDS INCLUDING 32 IEC AND 12 CEN 
Slide 5 Role of Govt

WHILE THE ADOPTION OF INDUSTRY STANDARDS ENABLES THE COAST GUARD TO FULFILL ITS REGULATORY FUNCTIONS MORE EFFICIENTLY, THIS CAPABILITY WOULD BE USELESS WITHOUT THE EXISTENCE OF MEANINGFUL STANDARDS. RECOGNIZING THIS REALITY EARLY ON, THE COAST GUARD AGGRESSIVELY PURSUED MEMBERSHIP ON A FULL RANGE OF STANDARDS-ORGANIZATIONS. TODAY WE SUPPORT ABOUT 30 NONGOVERNMENT ORGANIZATIONS AND ACTIVELY PARTICIPATE ON OVER 100 STANDARDS-COMMITTEES. THIS ACTIVE PARTICIPATION ENABLES US TO RAISE GENUINE ISSUES OF PUBLIC SAFETY AND PRESERVATION OF THE MARINE ENVIRONMENT. ADDITIONALLY, WHERE INDUSTRY HAS NOT ESTABLISHED SUTTABLE SAFETY REQUIREMENTS, WE CATALYZE THEIR DEVELOPMENT. 
Slide 6 Benefits

BECOMING AN INTEGRAL PART IN THIS PROCESS HAS ENABLED THE COAST GUARD TO AVOID DRAFTING UNNECESSARILY DETAILED REGULATIONS AND IN SOME CASES AVOIDING REGULATION COMPLETELY. IT HAS ALSO HELPED US TO EVOLVE FROM A REGULATORY PROCESS WHICH REACTS TO DISASTER TO A MORE ORDERLY PROCESS WHICH RECOGNIZES TECHNICAL INNOVATION AND PROGRESSIVE IDEAS AIMED AT PREVENTING DISASTER.

TO DATE WE CURRENTLY ADOPT APPROXIMATELY 300 INDUSTRY STANDARDS, SAVING OVER 25,000 PAGES OF FEDERAL REGULATIONS AND THE ASSOCIATED REGULATION MAINTENACE, WHILE SPECIFYING STANDARDS ALREADY FAMILIAR TO THE INDUSTRY REGULATED.

WE ESTIMATE THAT OUR PARTICIPATION ON STANDARDS COḾMITTEES SAVES US OVER \$1M ANNUALLY AND INCREASES OUR INSPECTION AND TECHNICAL FORCE 100 TIMES.

THIS LAST POINT IS EXTREMELY SIGNIFICANT. WHEN I GO TO A COMMTTEE MEETING I'VE GOT 30, 60 OR 100 EXPERTS WORKING FOR ME, DEVELOPING MY REGULATIONS.

WHEN WE ADOPT CERTIFYING MARKS , EG, ASME'S CODE SYMBOL STAMP OR UL'S MARK, I'VE GOT 100'S OF INSPECTORS AND LAB TECHNICLANS WORKING FOR ME 
Slide 7 Goal 1

ONE OF THE GOALS OF OUR STDS PROGRAM IS TO DEVELOP A

COMPREHENSIVE SET OF NATIONALLY RECOGNIZED,

INTERNATIONALLY COMPATIBLE STANDARDS THROUGH ACTIVE

PARTICIPATION IN NATIONAL STANDARDS ORGANIZATIONS.

WITH THE HELP OF INDUSTRY WE HAVE DEVELOPED A NUMBER OF STANDARDS TO MEET REQUIREMENTS OF INT'L CONVENTIONS, SUCH AS SOLAS AND MARPOL, e.g. AT ASTM WE FORMED A WG TO DEVELOP STDS FOR SHIPBOARD INCINERATORS. WE GOT REPS FROM JAPAN \& EUROPE TO PARTICIPATE TO ENSURE THE STANDARD'S INT'L ACCEPTANCE. THIS ASTM STD WAS DEVELOPED IN 2 SHORT YEARS AND IS NOW ADOPTED BY IMO AND ISO. OTHER STDS INCL WATERTIGHT DOORS AND PLASTIC PIPE . IN ADDITION, WE ARE CURRENTLY REDRAFTING A NUMBER OF ASTM STANDARDS TO PROPOSE AS INTERNATIONAL ISO STANDARDS. "

WE HAVE SPEARHEADED AN EFFORT TO GET ASME TO ADOPT IN THEIR CODES FOREIGN MATERIAL STANDARDS SUCH AS JS, DIN, AND ISO. THIS WILL FURTHER ENHANCE THE INT'L ACCEPTANCE OF ASME CODES AND STDS AND IMPROVE THE COMPETIVENESS OF US SHIPPING.

AT NFPA WE HAVE ESTABLISHED A NEW COMMTTTEE TO ADDRESS MARINE RELATED FIRE PROTECTION ISSUES. THE NEED FOR THIS COMMITTEE BECAME APPARENT WITH THE ADVENT OF THE RIVERBOAT GAMING INDUSTRY. OUR REGS WERE NOT GEARED FOR THESE HIGH PASSENGER DENSITY VESSELS WITH LARGE OPEN SPACES AND ATRIUMS EXTENDING THROUGH MULTIPLE DECKS. OUR GOAL IS TO DEVELOP A LIFE SAFETY CODE FOR SHIPS PATTERNED AFTER NFPA'S LIFE SAFETY CODE FOR BUILDINGS. THIS WILL GIVE THE DESIGNER MORE FLEXIBILITY BY PROVIDING A NUMBER OF DESIGN OPTIONS AND TRADEOFFS. 
Slide 8 Goal 2

ANOTHER GOAL OF OUR STANDARDS PROGRAM IS:

TO DEVELOP A COMPREHENSIVE SET OF INTERNATIONALLY

RECOGNIZED STANDARDS THROUGH ACTIVE PARTICIPATION IN IMO

AND OTHER INTERNATIONAL STANDARDS MAKING ORGANIZATIONS

SUCH AS ISO AND IEC.

WE ARE CONTINUING TO WORK AT IMO TO "LEVEL THE

INTERNATIONAL PLAYING FIELD." THIS IS BEING DONE BY RAISING

INTERNATIONAL SAFETY REQUIREMENTS TO THE LEVEL EXPECTED BY

THE AMERICAN PUBLIC. IN ADDITION, WE ARE WORKING TO ELIMINATE AMBIGUOUS REQUIREMENTS IN SOLAS SUCH AS PHRASES LIKE "SUBJECT

TO THE SATISFACTION OF THE ADMINISTRATION." THESE PHRASES LEAD

TO A WIDE VARIETY OF INTERPRETATION AND ENFORCEMENT;

STANDARDS ARE AN EFFECTIVE WAY TO ELIMINATE THESE AMBIGUOUS

PHRASES. IN THIS REGARD, WE ARE WORKING TO INCREASE IMO'S

ACCEPTANCE OF STANDARDS DEVELOPED BY OTHER ORGANZZATIONS. A GOOD EXAMPLE IS IMO'S ACCEPTANCE OF THE SHIPBOARD INCINERATOR STANDARD DEVELOPED BY ASTM AND EMBRACED BY ISO. AT ISO WE HAVE A NUMBER OF STANDARDS UNDER DEVELOPMENT REQUESTED BY IMO. MANY OF THESE STANDARDS ARE BENG DEVELOPED BY SUBCOMMITTEES LED BY THE UNITED STATES. THESE STANDARDS WILL FILL THE GAP, IMPROVE SAFETY, AND LEVEL THE PLAYING FIELD FOR ALL. 
Slide 9 Goal 3

AND LAST BUT NOT LEAST OUR GOAL IS TO IMPROVE COMPETITIVENESS

OF THE U.S. MARITIME INDUSTRY BY REMOVING REGULATORY AND OTHER BARRIERS THAT IMPEDE PRODUCTIVITY AND A FREE FLOW OF COMMERCE.

THIS GOAL IS BEING ACHIEVED BY USING INTERNATIONALLY AND NATIONALLY AGREED UPON STANDARDS AS ALTERNATIVES TO REGULATIONS AND BY PROMOTING DEVELOPMENT OF PERFORMANCE BASED STANDARDS RATHER THAN DETAILED SPECIFICATIONS AS THE MEANS OF COMPLIANCE. RECENTLY WE PUBLISHED SWEEPING REG REFORM CHANGES TO OUR ELECTRICAL ENGINEERING REGS. WE ADOPTED 86 NEW STANDARDS INCLUDING 32 IEC AND 12 CEN!

IN ADDITION, WE ARE EMBARKING ON THE USE OF RISK-BASED METHODOLOGIES TO DETERMMNE THE LEVEL AND DEGREE OF " STANDARDIZATION NEEDED. USING RISK BASED METHODS IN A TOP DOWN SYSTEMS ENGINEERING APPROACH WE CAN DETERMINE THE RELATIVE SAFETY HAZARDS AND DETERMINE THE EFFECTIVE LEVEL OF STANDARDIZATION NEEDED. USING RISK BASED METHODS ON SPECIALLY DESIGNED CARGO VESSELS,WE SAVED OVER \$2M PER VESSEL.

IN SUMMARY, THE COAST GUARD IS COMMITTED TO DEVELOPING THE STANDARDS NEEDED TO IMPROVE SAFETY, PROTECT THE ENVIRONMENT, AND REDUCE THE COST OF GOVERNMENT REGULATIONS. 




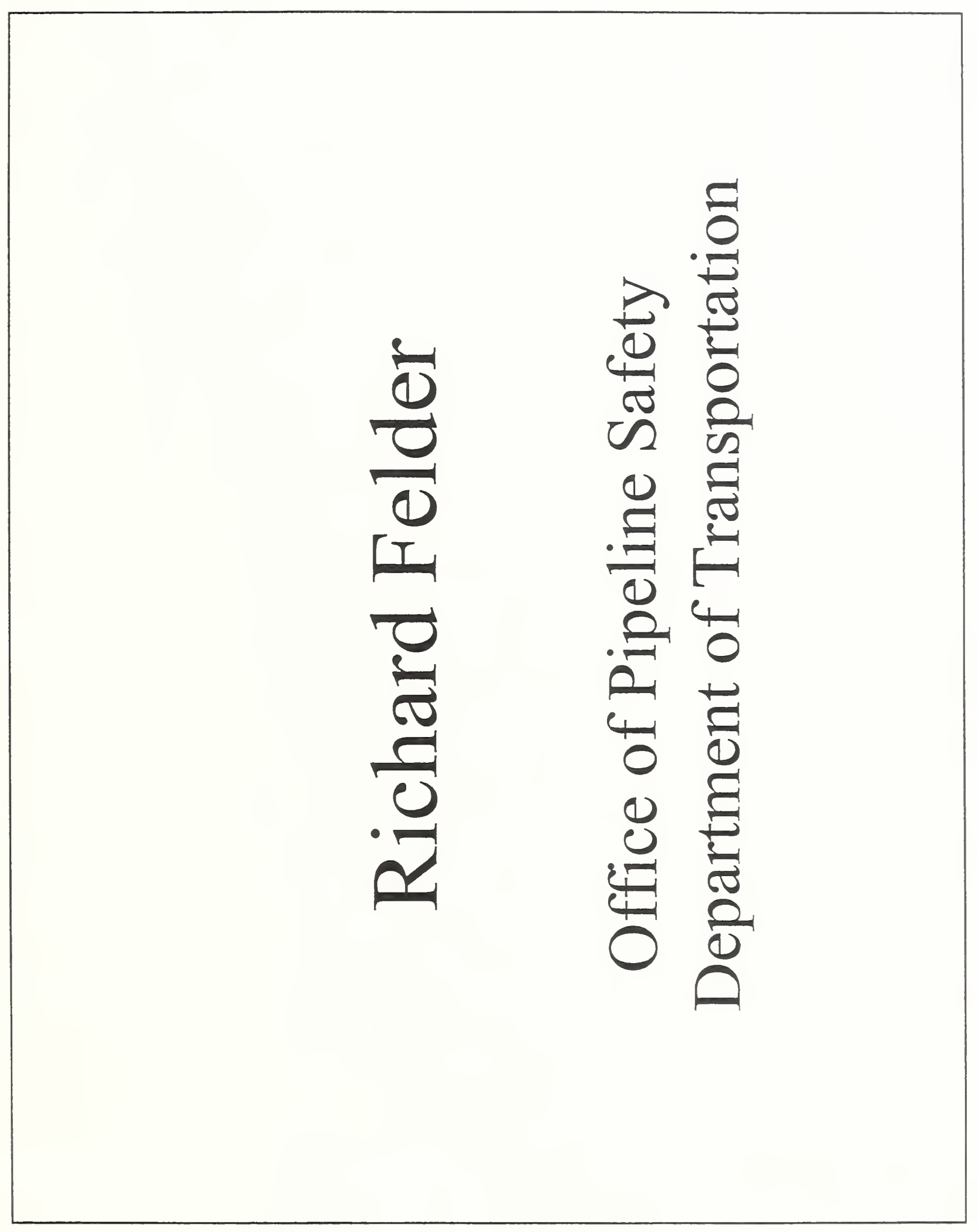






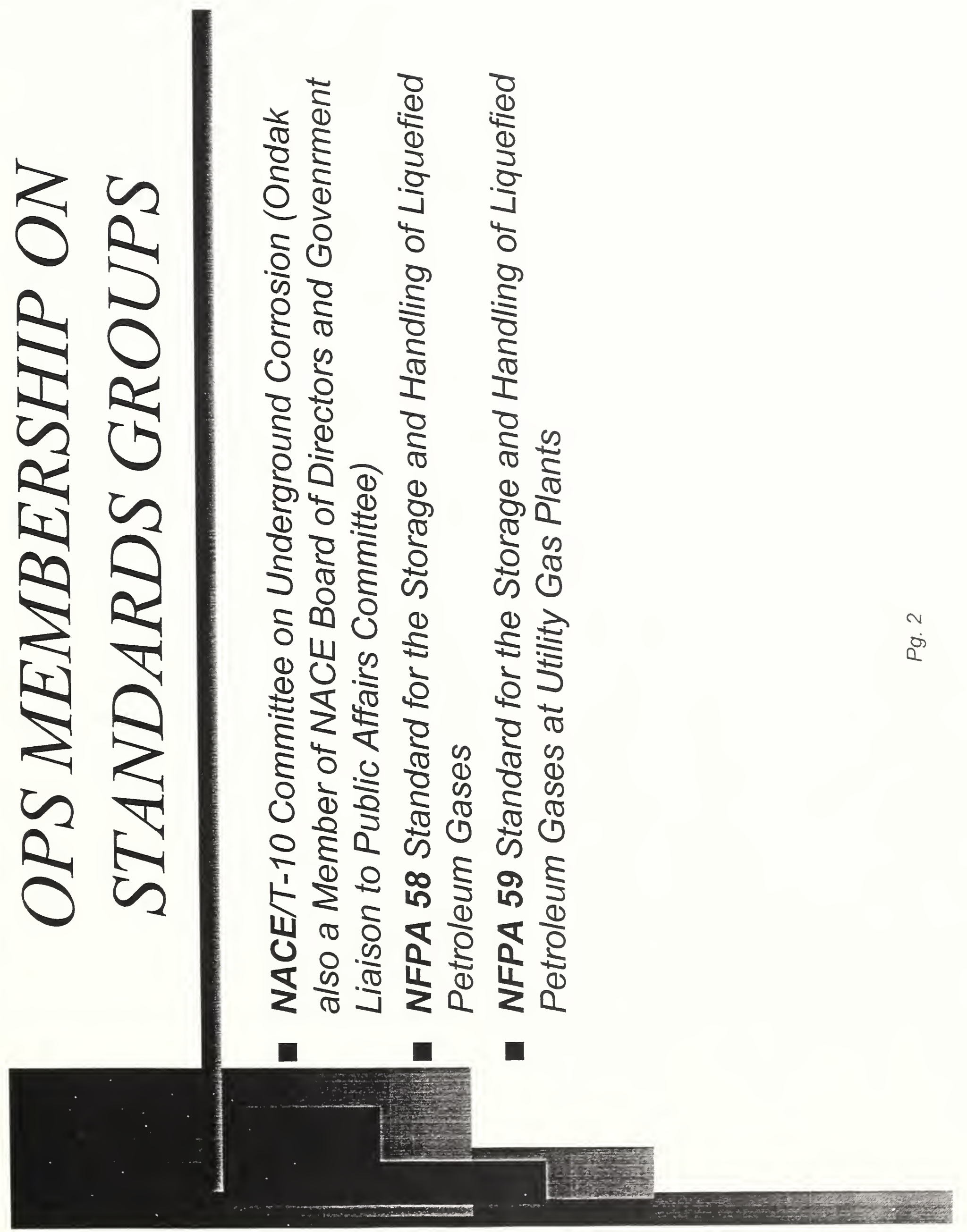







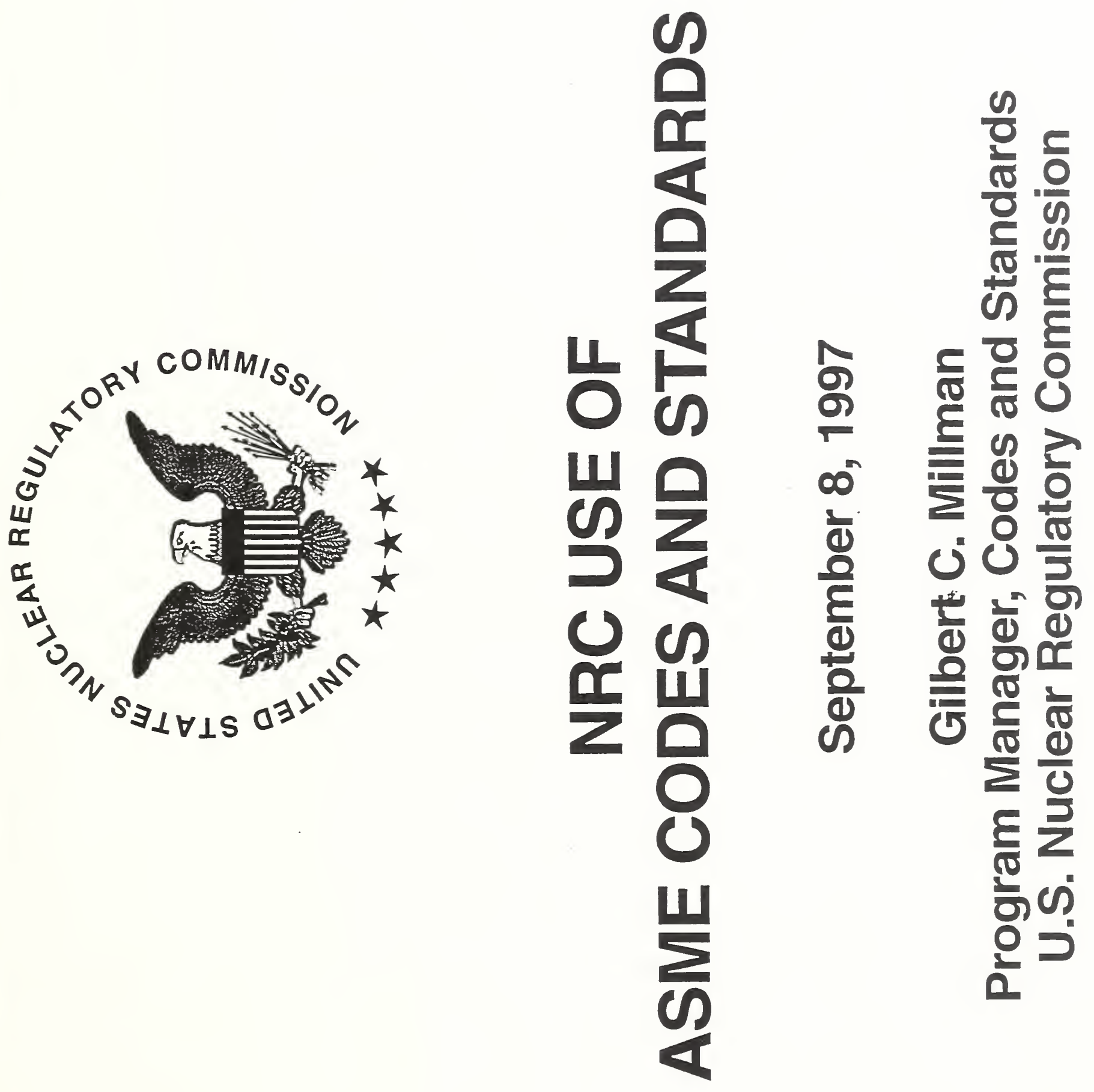




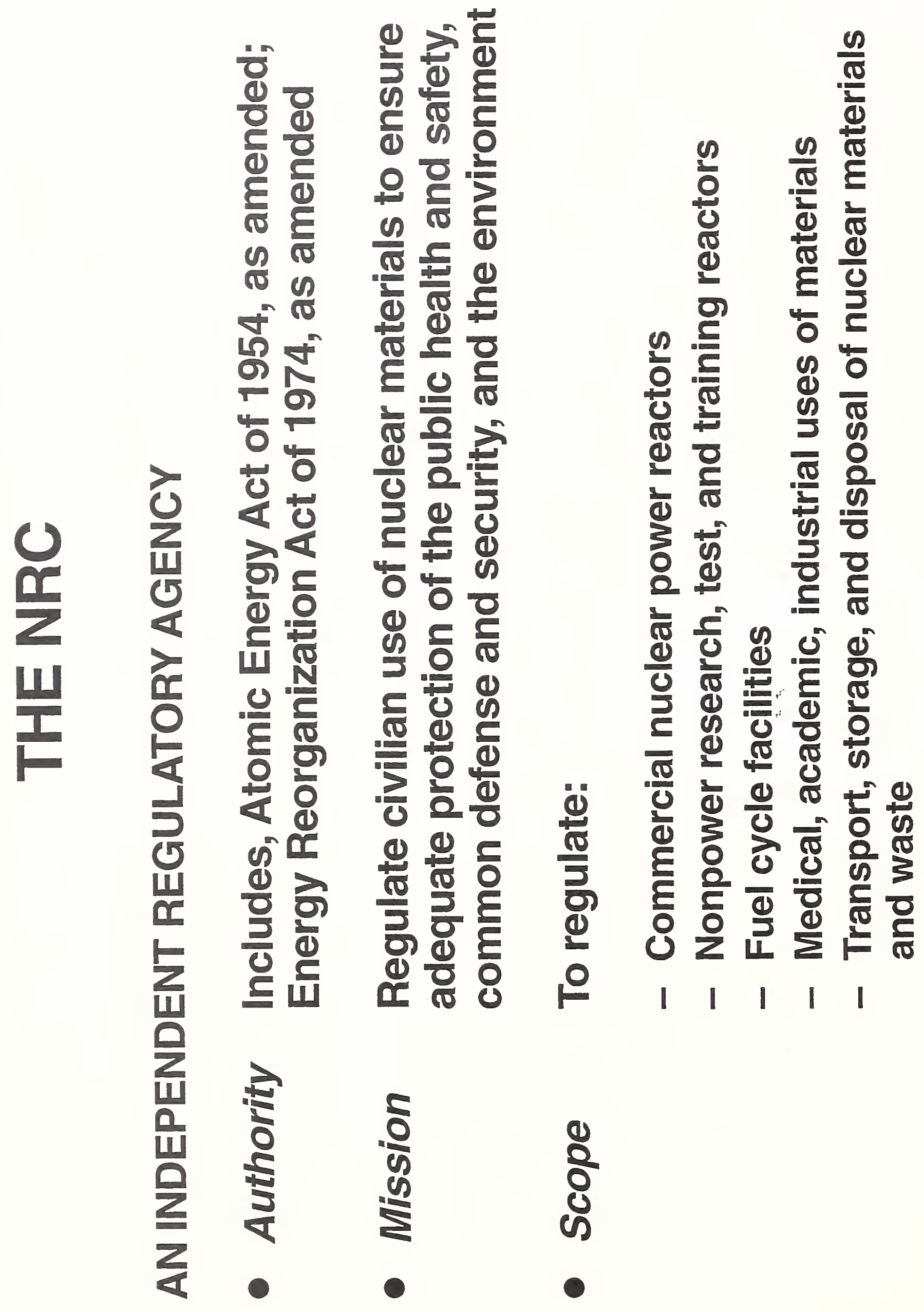




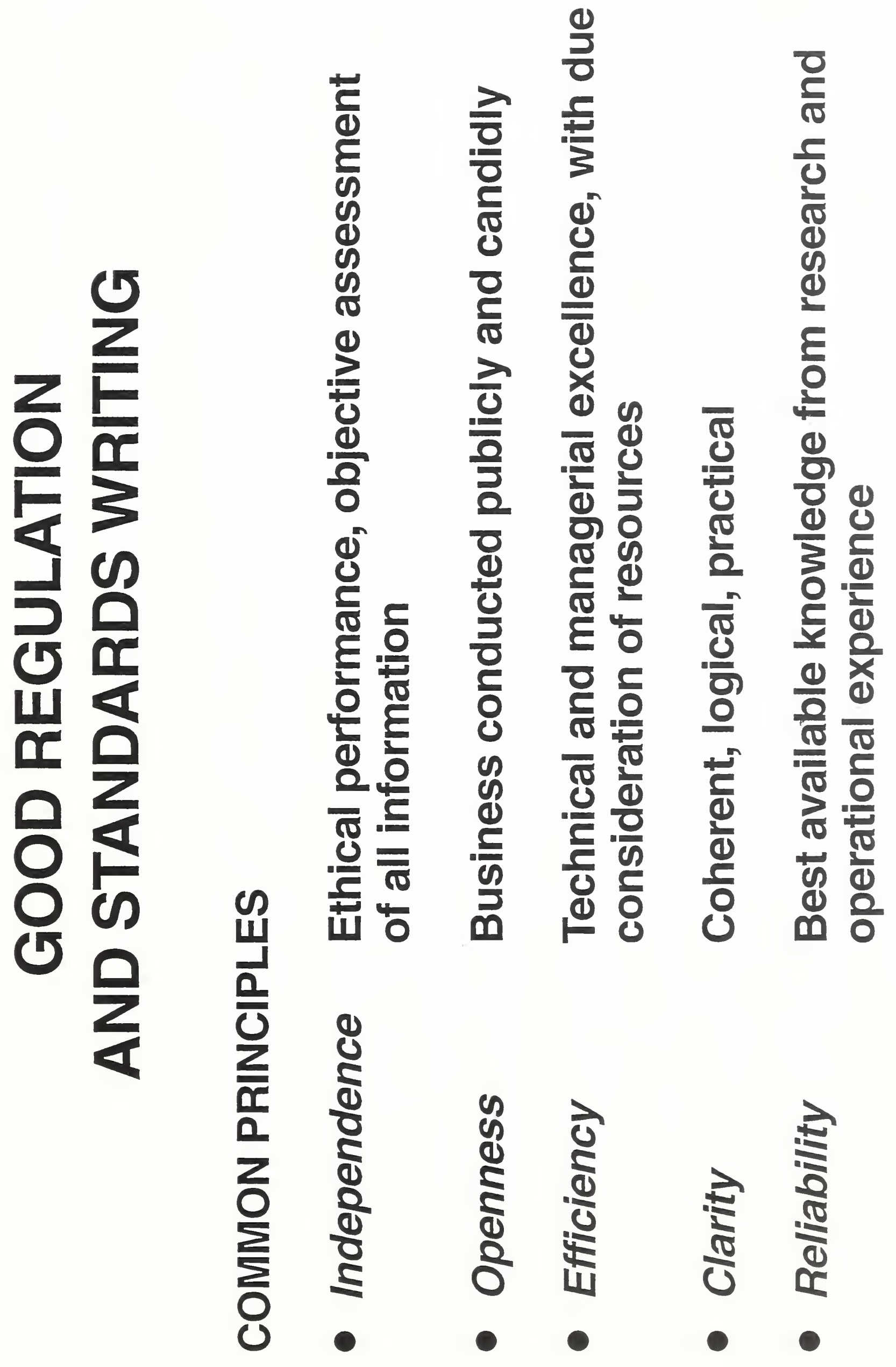



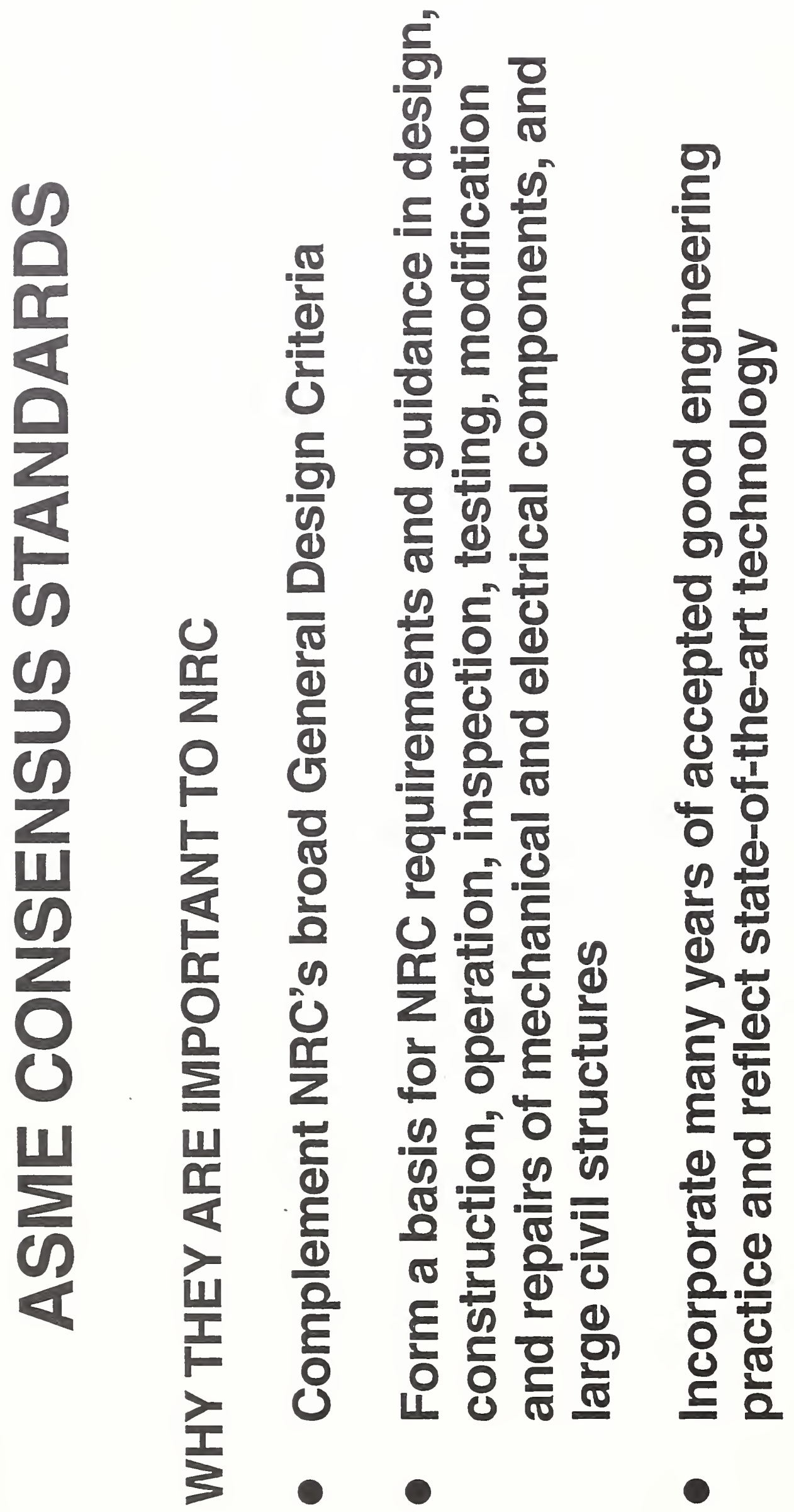

$\omega$

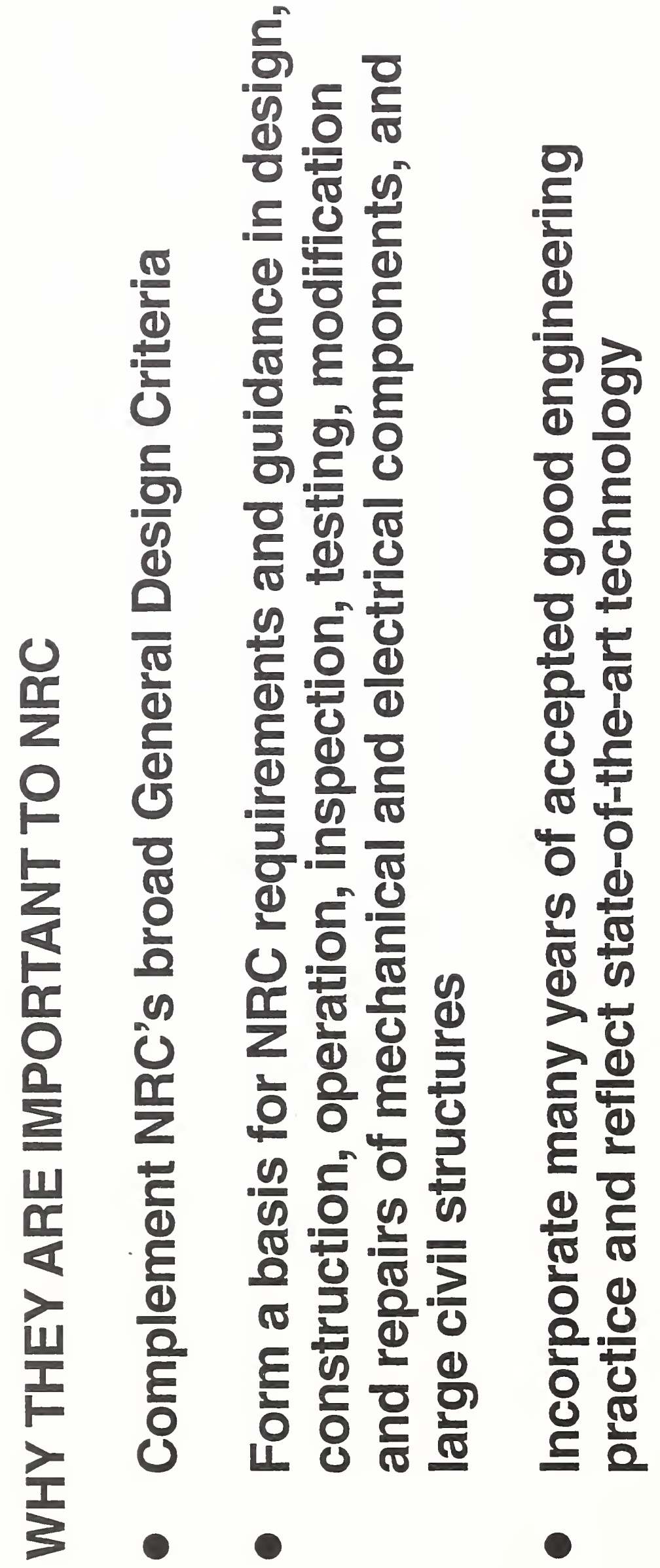

舟

(

은 

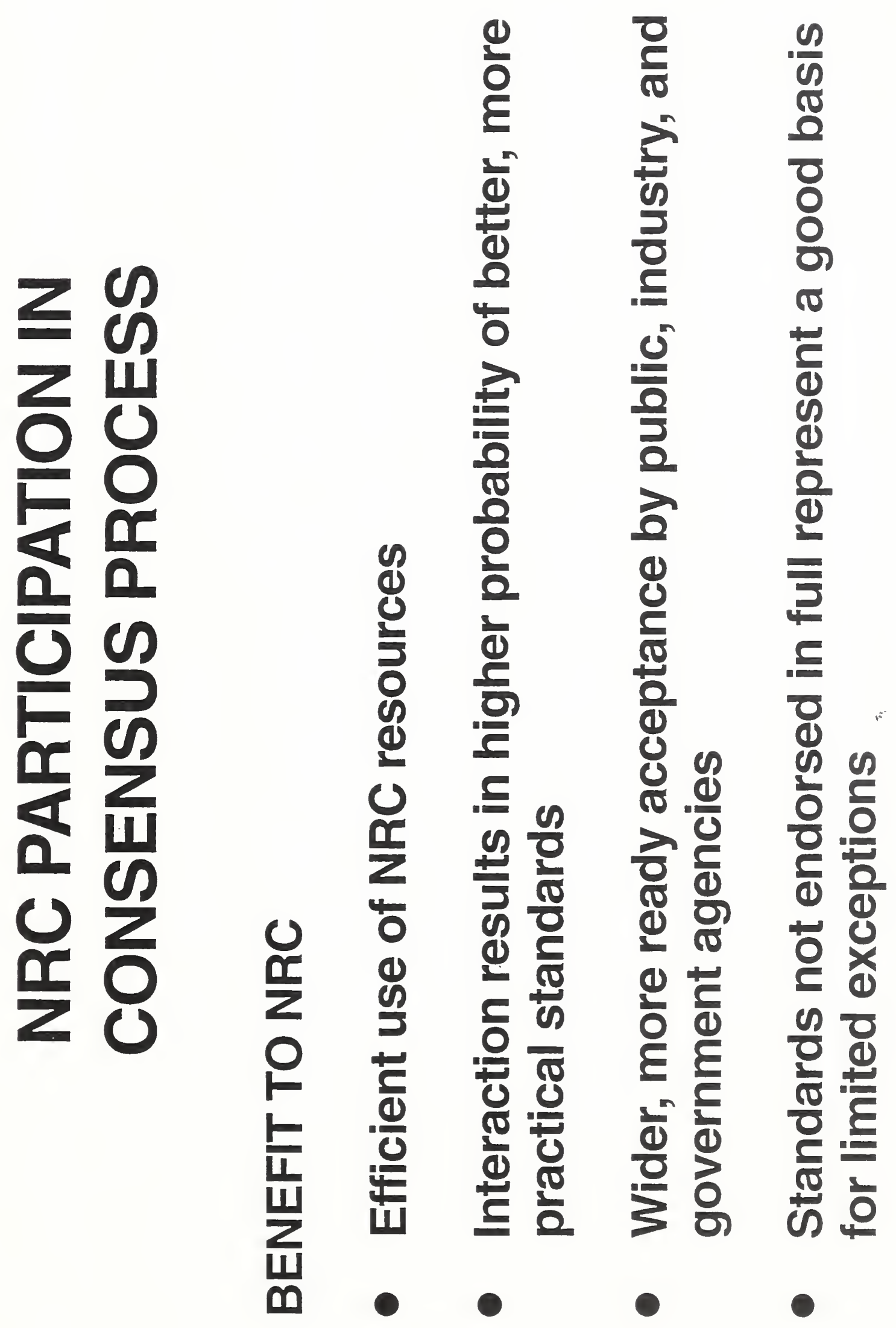


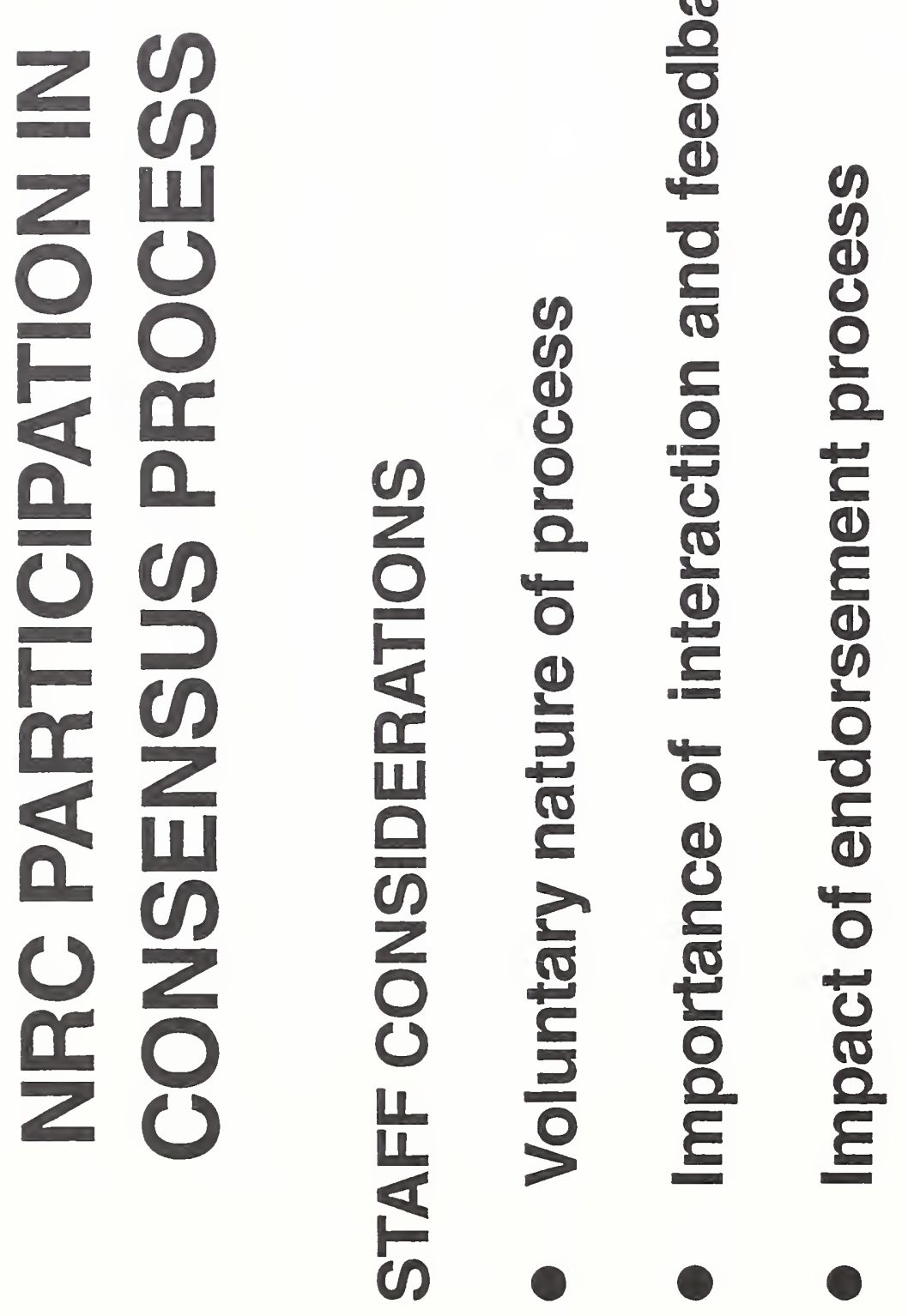




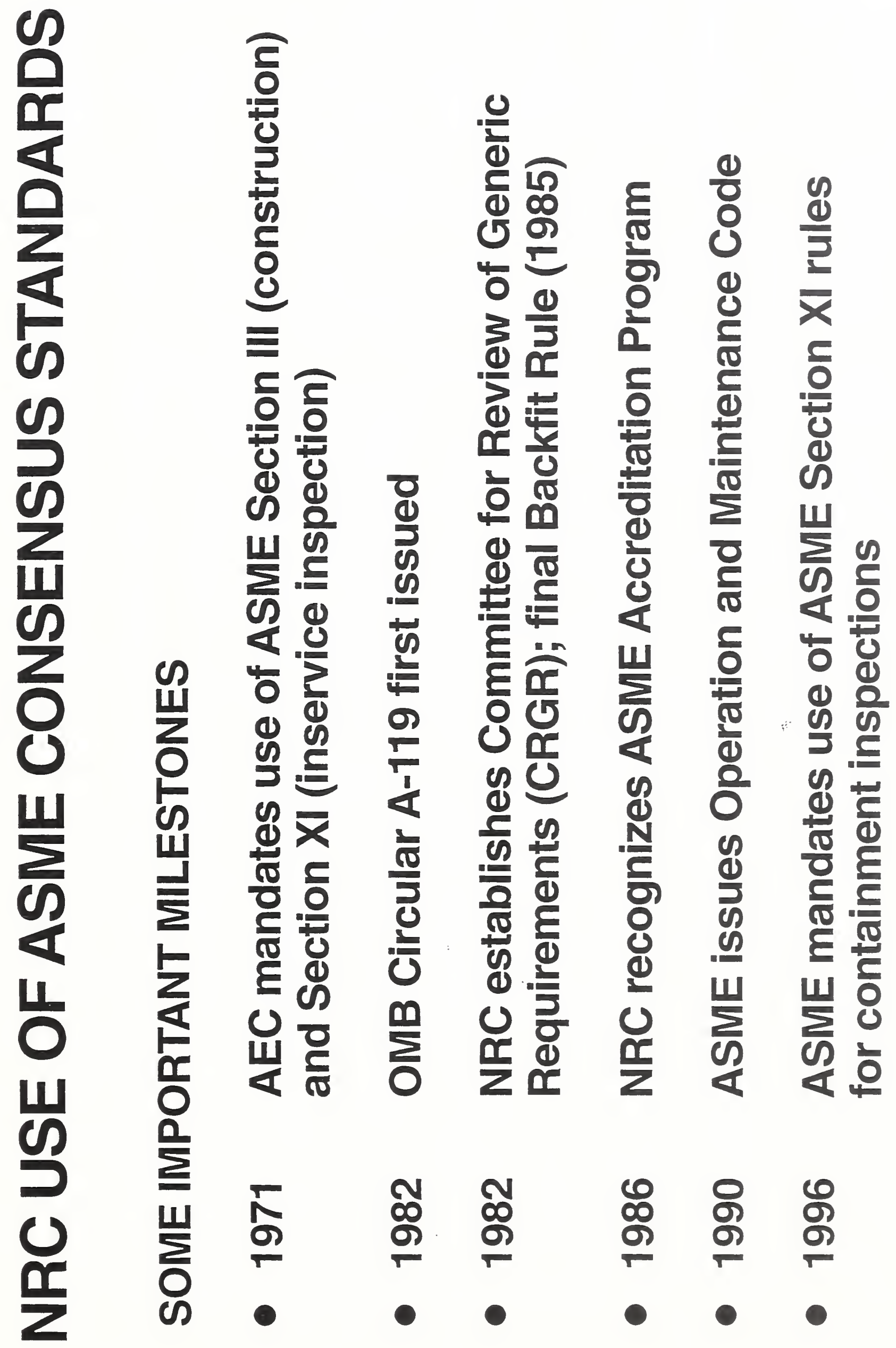




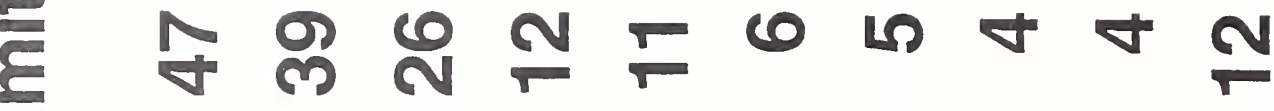

0 ठ ํ

只

0

2

2

F

4

口

0

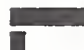

r

$\frac{1}{8}$

U

0

o

ब

d

을

E

$\stackrel{\Phi}{\stackrel{5}{\circ}}$

음

뜨

0

둥

○

한

$\overline{0}$

을

이

흥

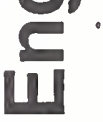

里

은

온

잉

(1)

II

$\frac{1}{0}$

4

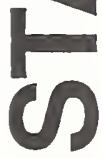

iI

을

ए प

क त

○

W

III

ด ณ

孚

$\frac{2}{2}$

응 $\frac{10}{0}$
$>$ 는 은

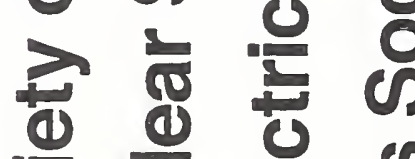

\&

ᄃ

듕 대워

은 응 롤

ह ह त

है

İ $\frac{0}{\sigma}$

(ब) है

(0) 0 क 5

$\geq 0$

- 0 Q 1

르를

ㅇ) $\frac{\theta}{0}$ ब है

단 01

$c$

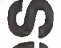

(1) 0

(1) है ए ए

¿ 2 के

市

겅

(1) 은 잉

-

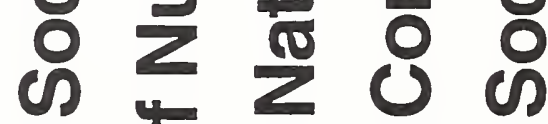

o 5 E

त 0 त ब

은 0.0

는

(1)

है क

है है है

ᄂ)

(1)

당

1 


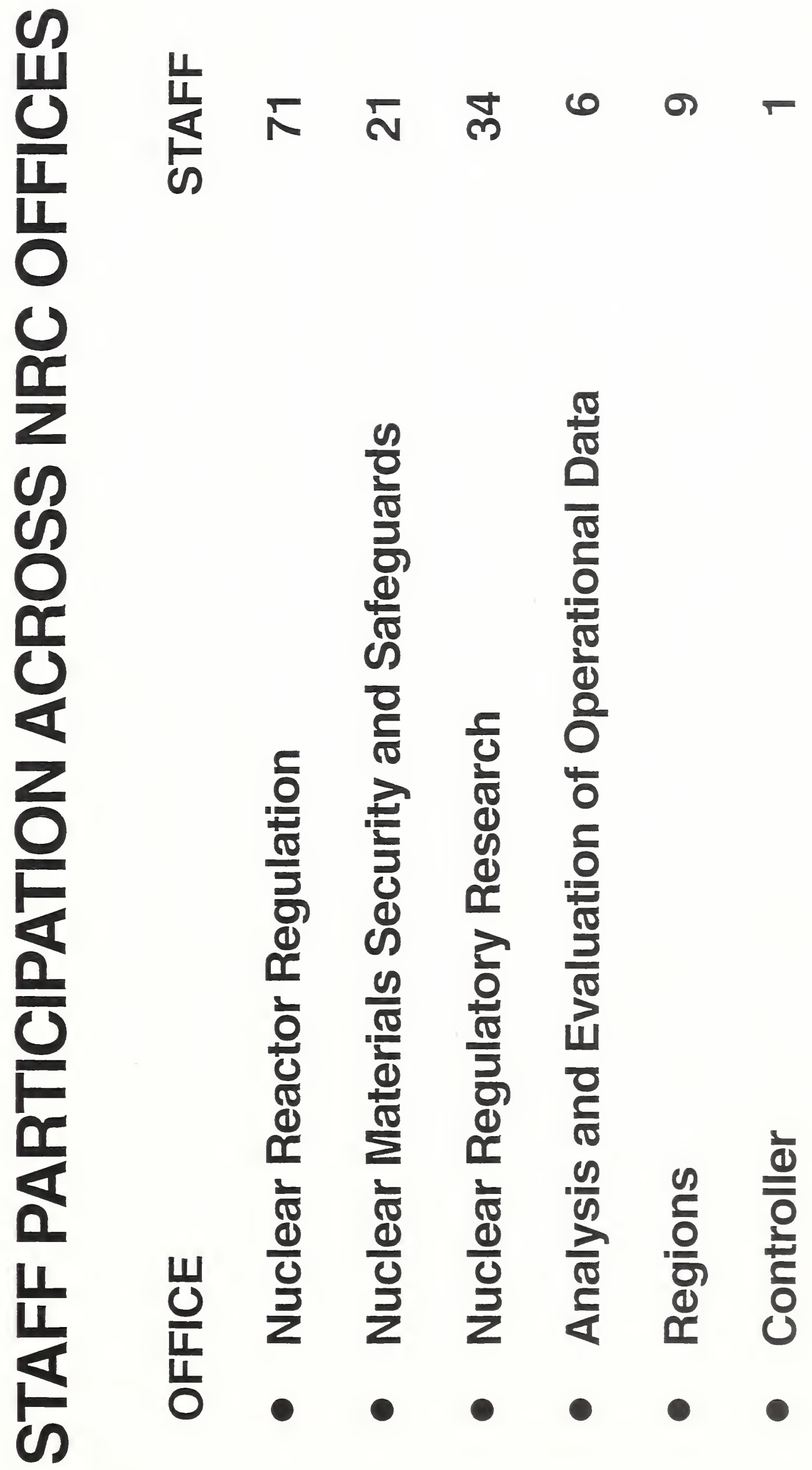




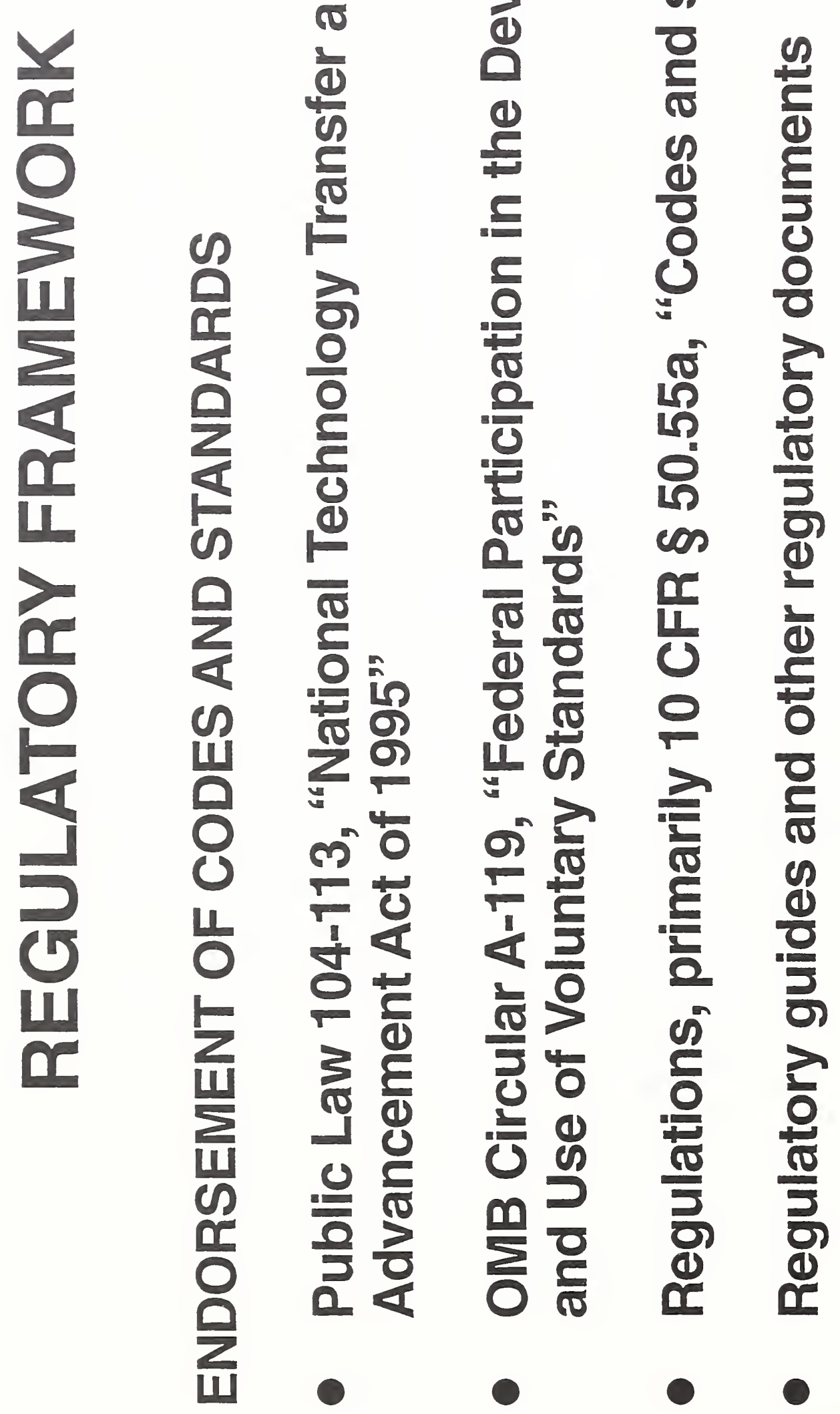



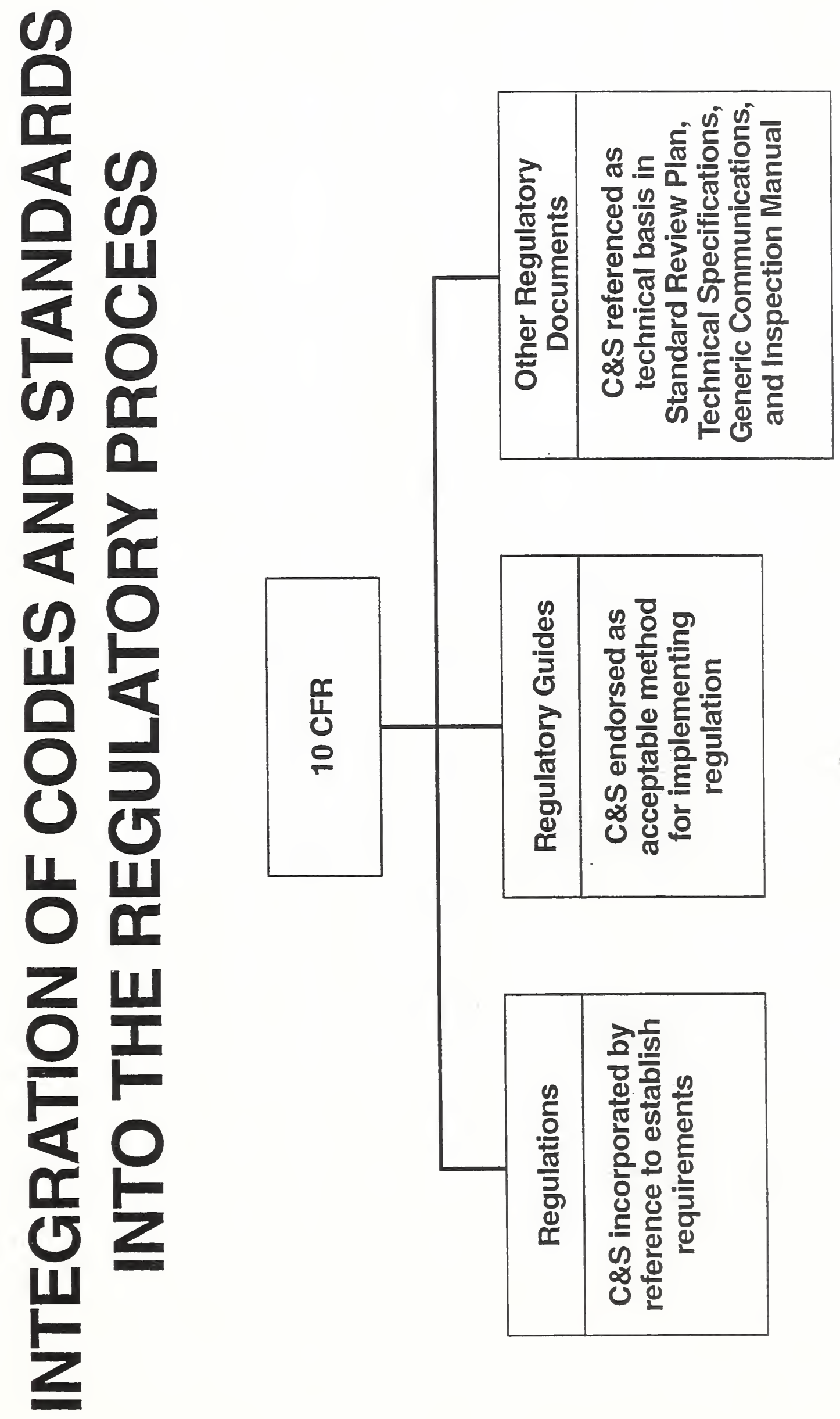


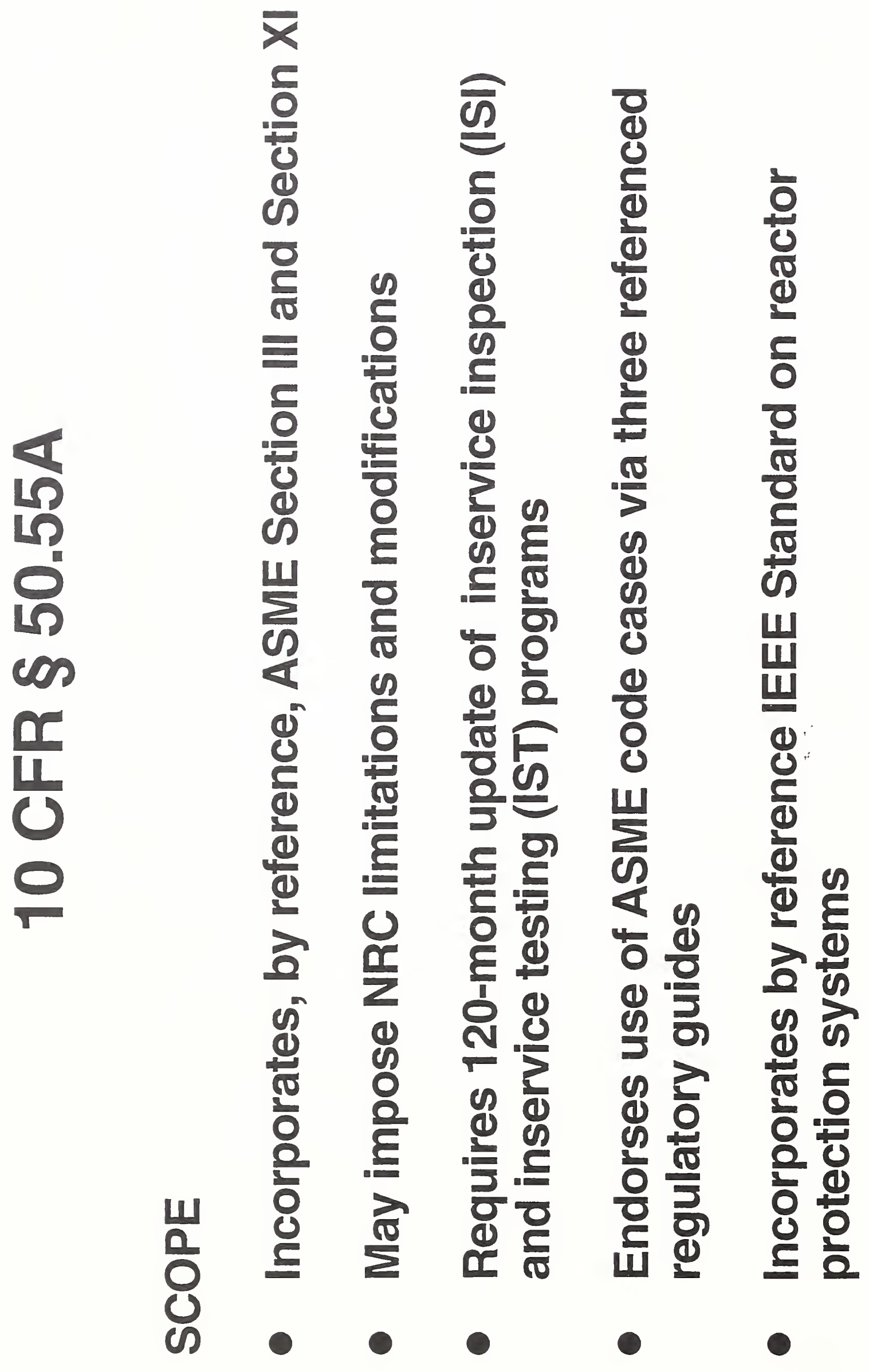




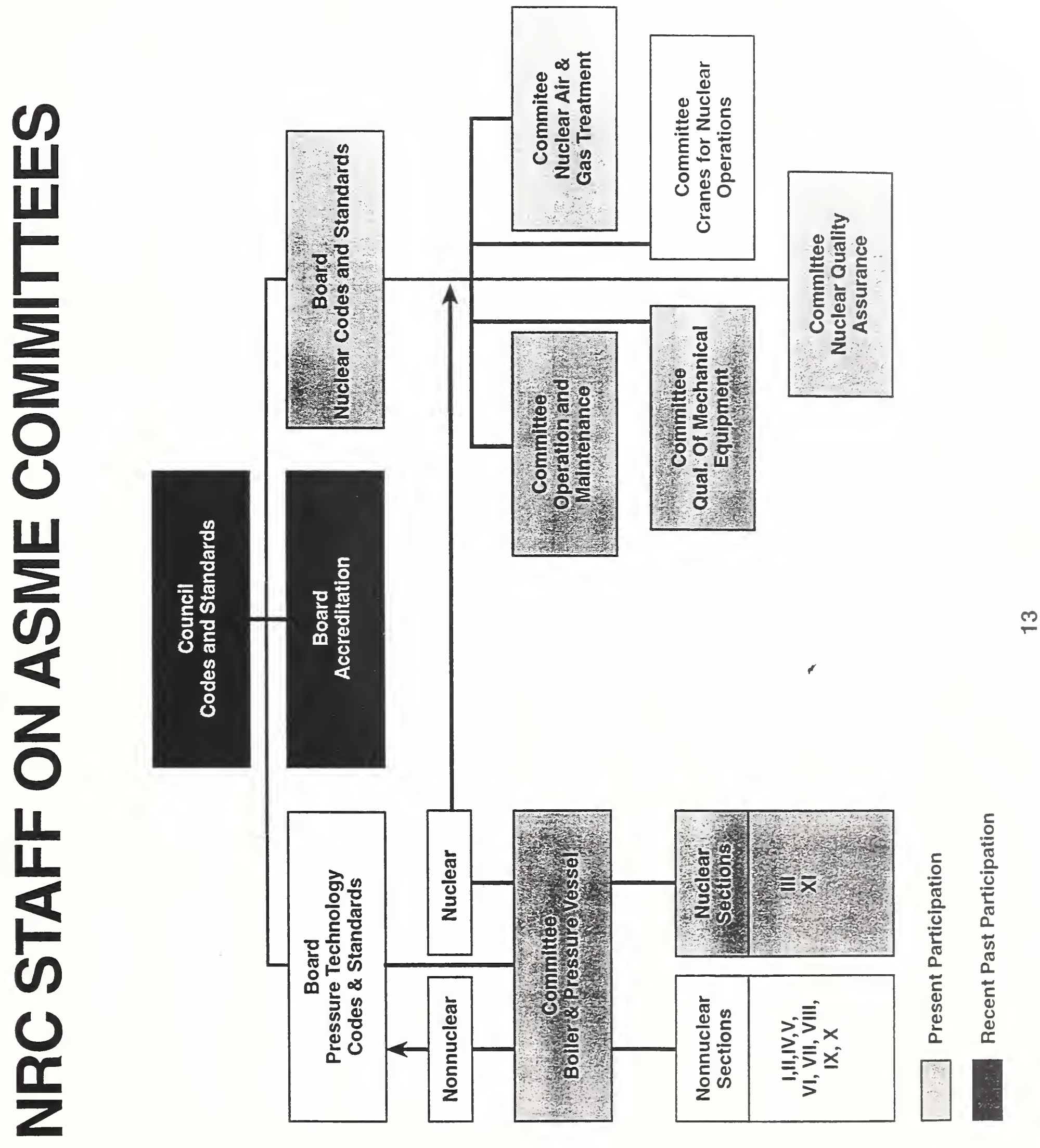




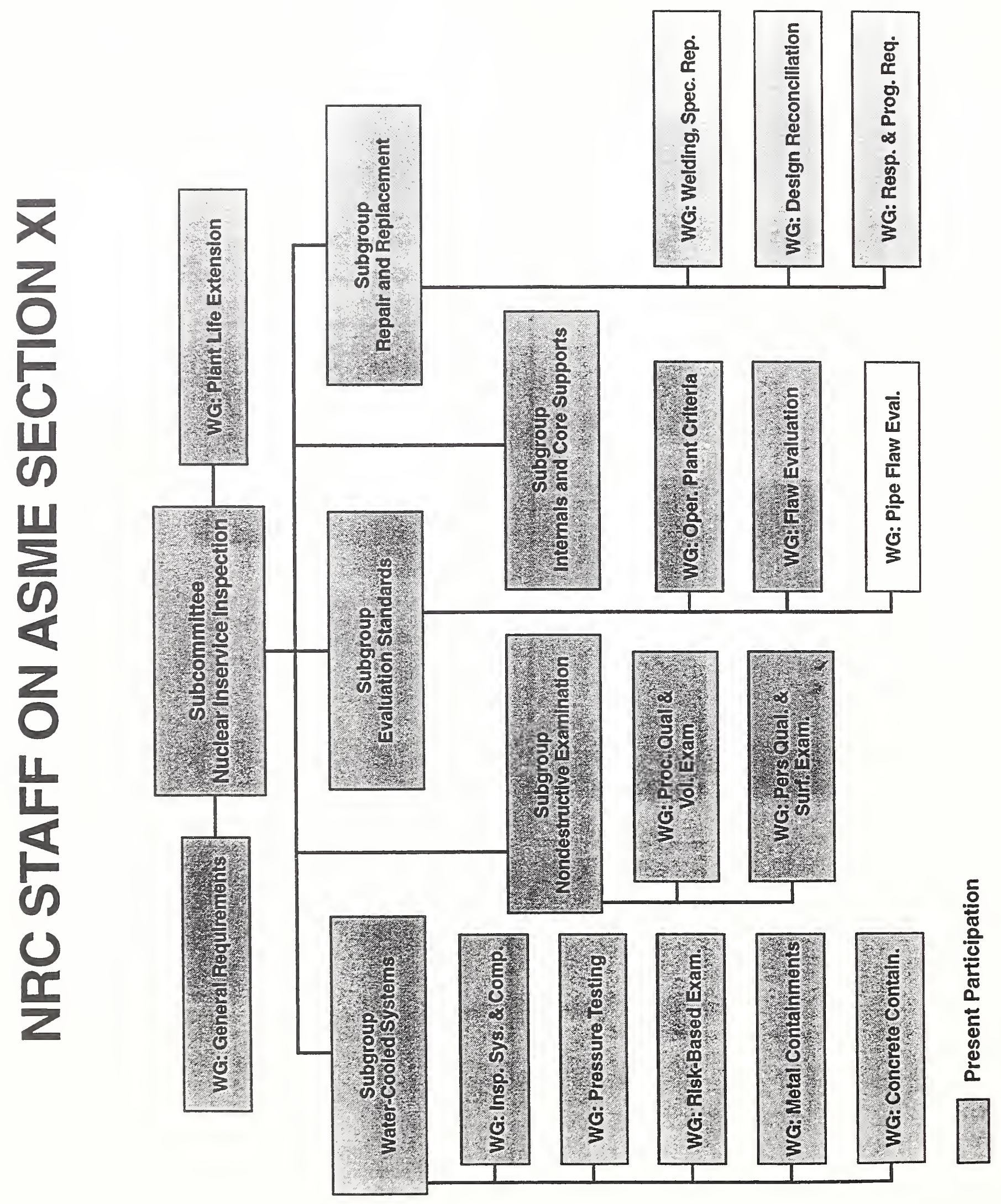




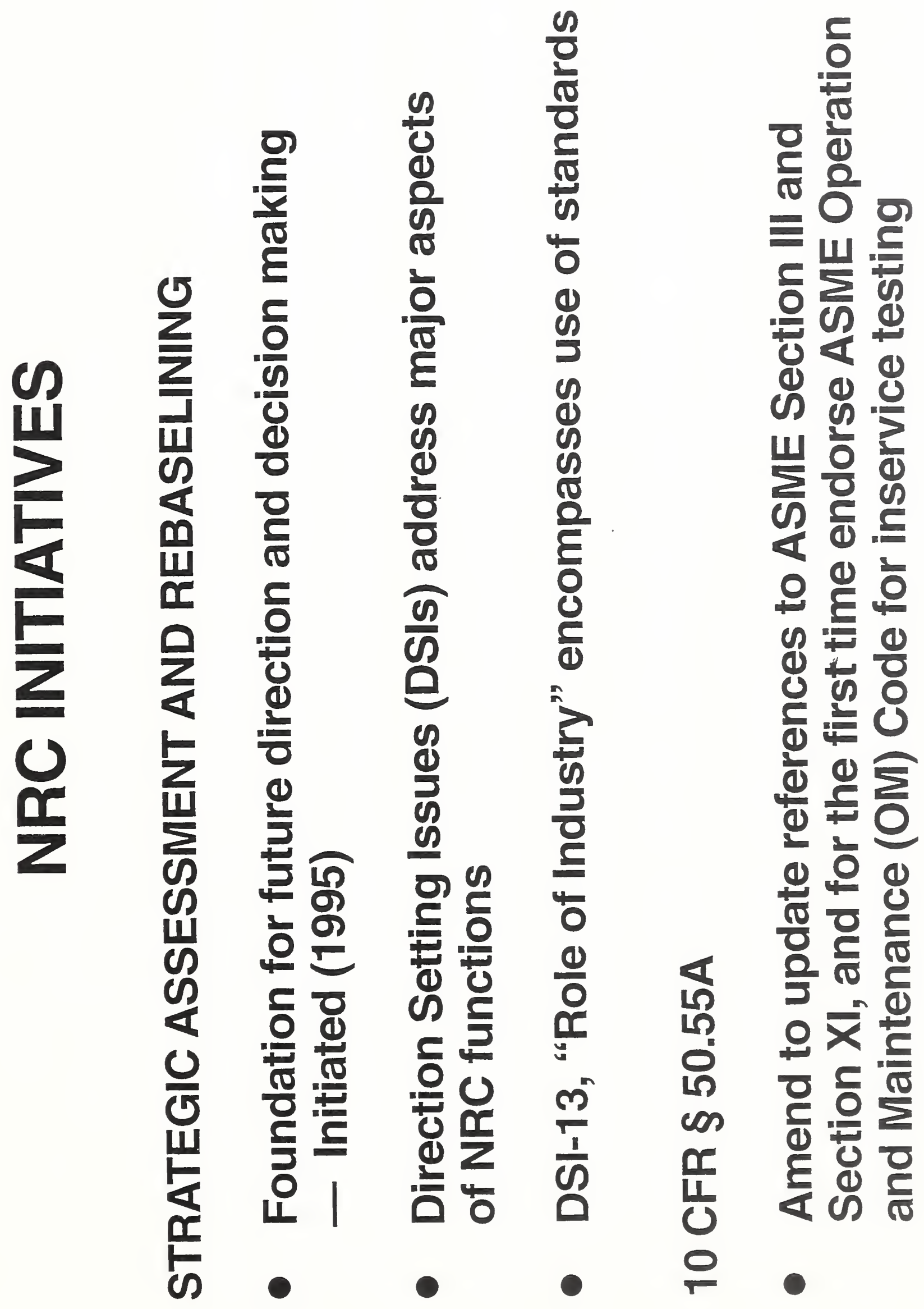



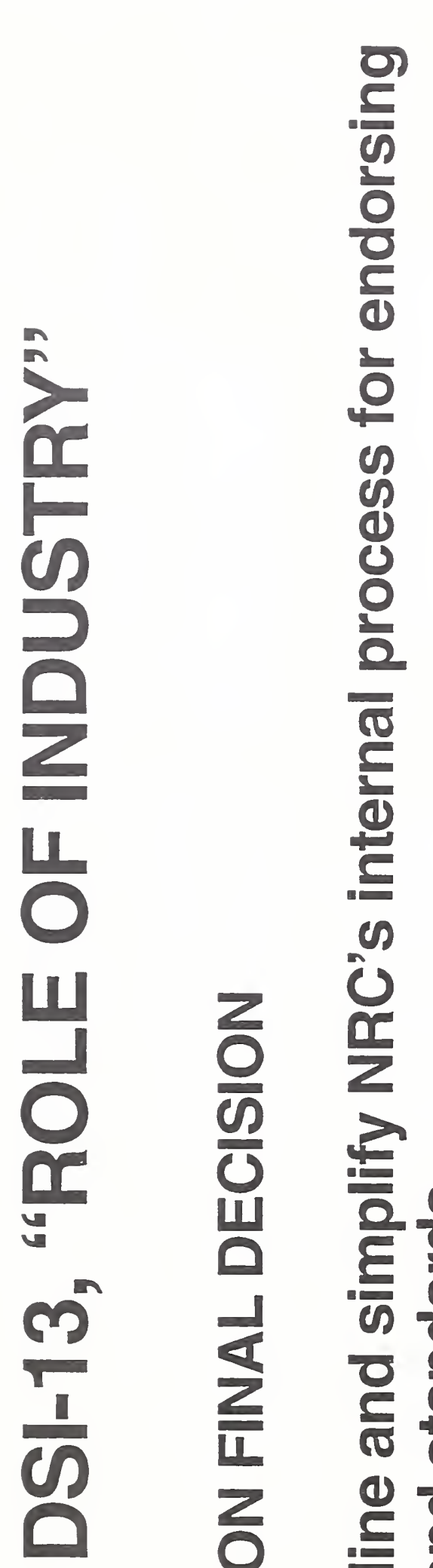

D

d

U

는

중

든

(d)

를

影

( )

U

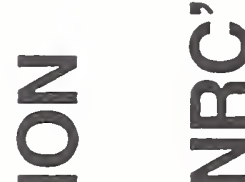

क

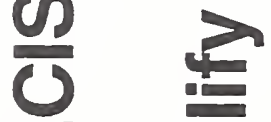

프

0

ก

$\frac{1}{0}$

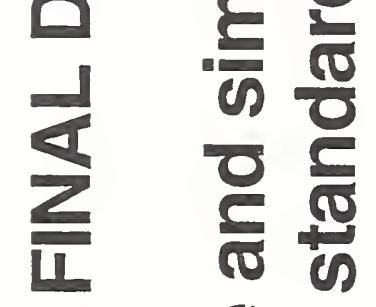

픈

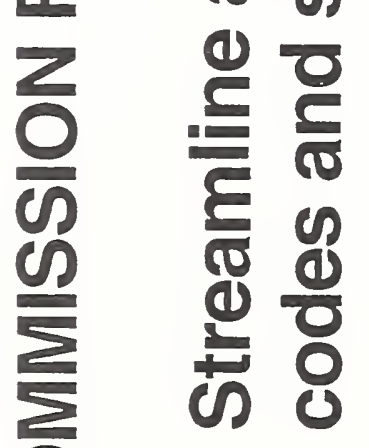

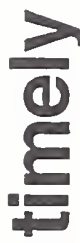

(1)

产

क

들

(1)

$+$

응 을

츙

을 윰

d

등

$\pi$

든

E 응

을 䎡

(1)

롱

$\pm \frac{2}{\sigma}$

o

0

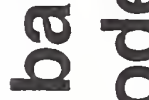

$\div 0$

ब1

는

5

잉

त)

हํํ응

อ ำ

동으

돈 $\frac{\pi}{5}$

드응

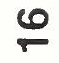

$m$

5

$\Gamma$

\&

둥당

3

으 히

형융 응

드

잉

오

.

है

क잉

a 을

ด.

두

둔

ब)

ह $\frac{1}{\sigma}$

ब 5

을 인

트 잉

0

플

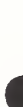




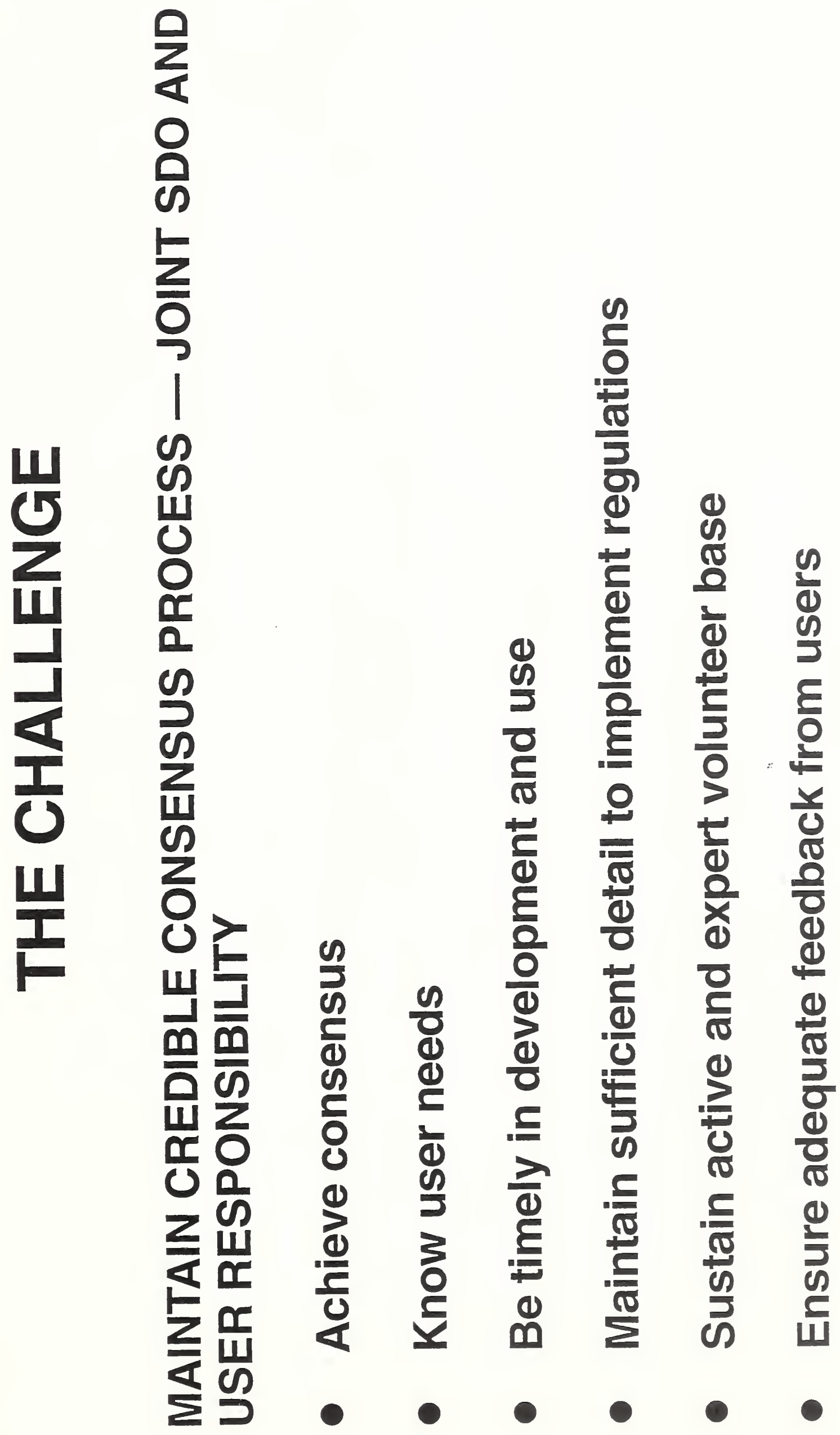




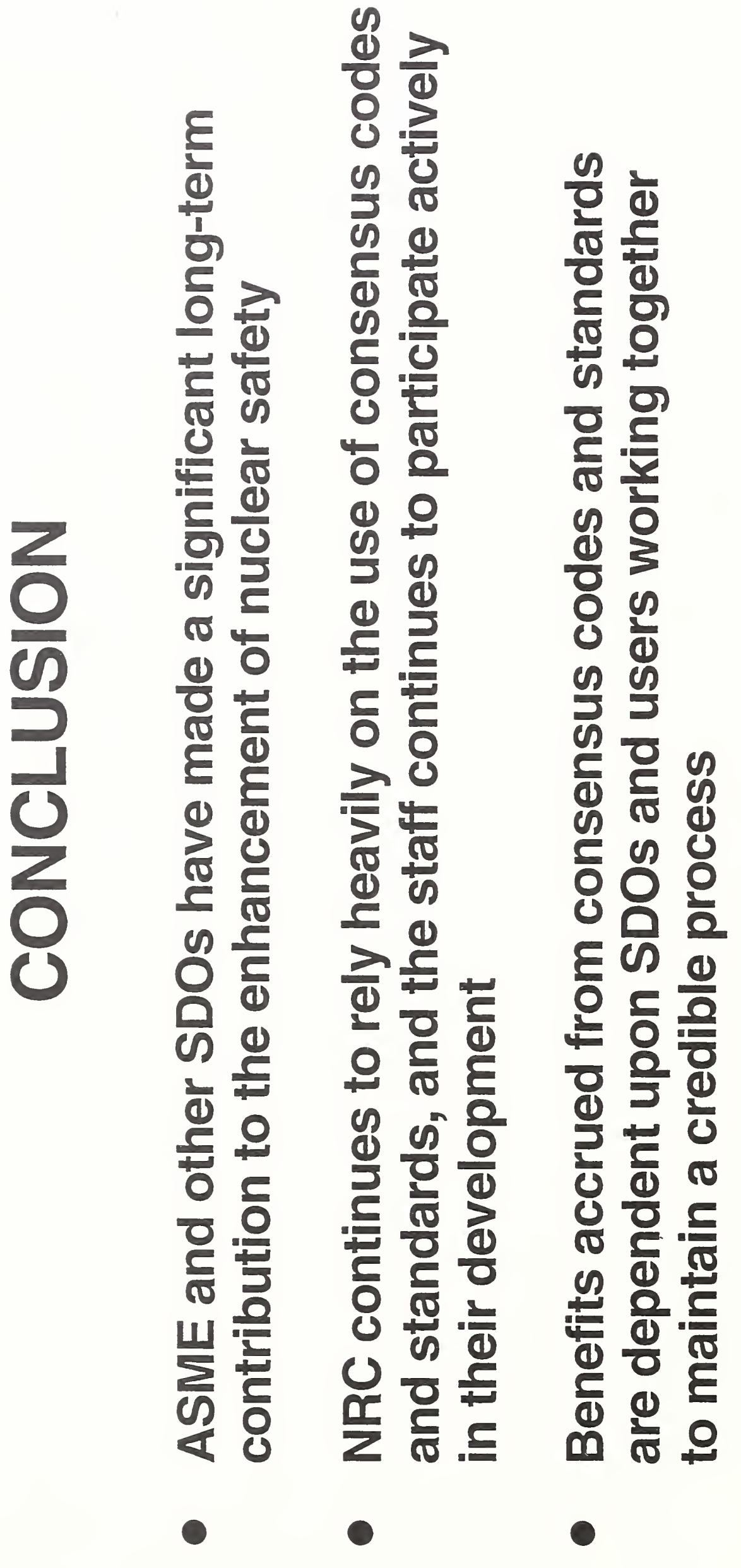





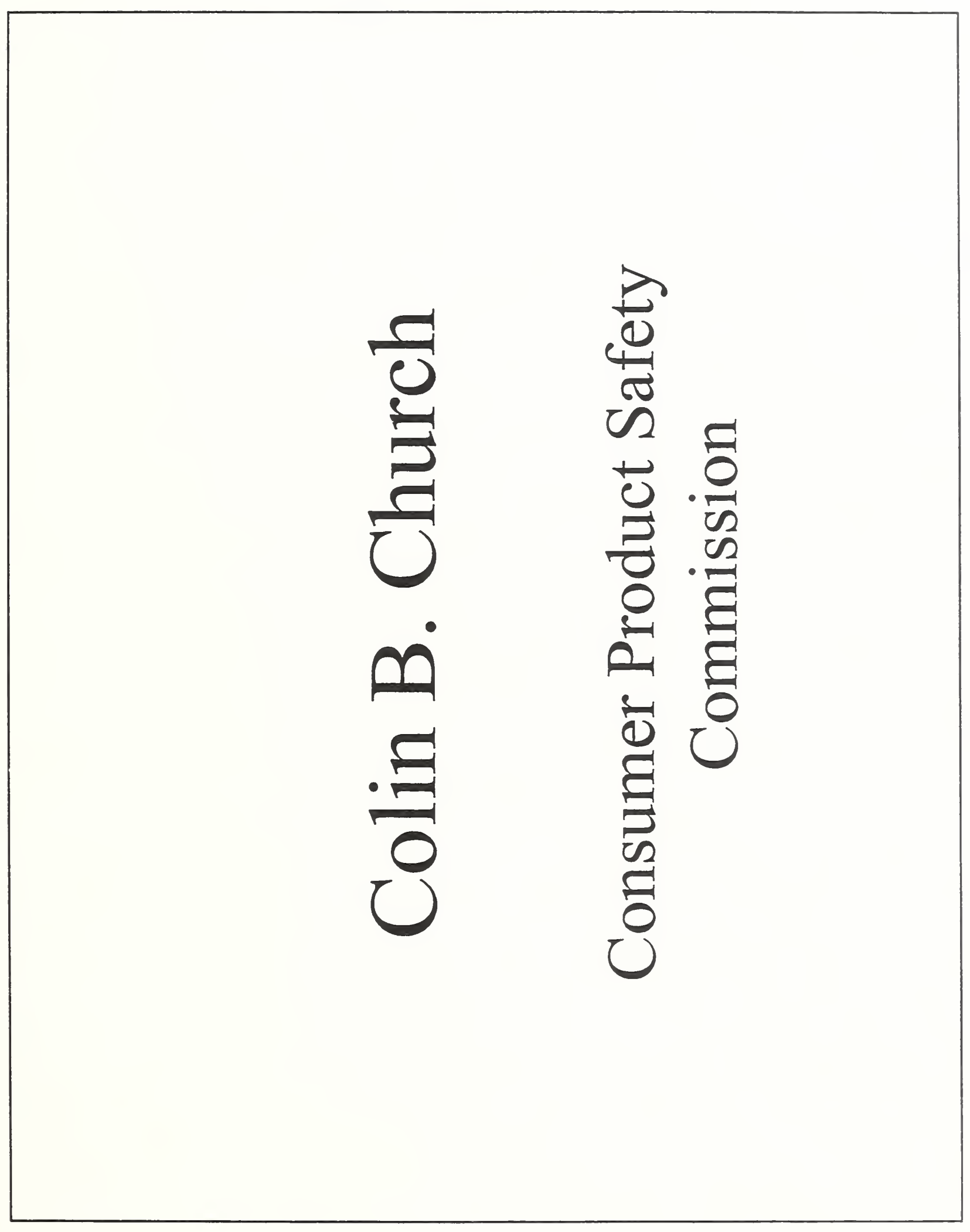





\section{BACKGROUND}

Saving lives and reducing serious injuries is the business of the U.S. Consumer Product Safety Commission (CPSC). To help do this the Commission has been providing technical support to the development of national consensus voluntary standards since it was established nearly 25 years ago.

The Commission is an independent federal regulatory agency established by Congress in 1973 to protect the public from unreasonable risks associated with consumer products. It was established to reduce the tragic estimated annual losses of 21,400 deaths, 29,400,000 injuries resulting in hospital emergency room visits, and $\$ 200$ billion in societal costs associated with consumer products.

To help reduce these losses, the Commission has worked with national consensus voluntary standards coordinating/developing groups for over two decades to provide effective, timely safety standards. CPSC staff provide injury information and technical support to 40-50 standards develốpment activities each year. These are handled primarily by ANSI, ASTM, and UL. Not only is it a statutory requirement that the CPC use voluntary standards, subject to certain caveats, it is believed that in so doing the Commission also saves time and money.

In the future, it seems likely the CPSC will continue to utilize nongovernment safety standards. At the same time the CPPSC staff will seek to improve: (1) the effectiveness and industry use of consumer product voluntary safety standards, (2) openness and balance of interests in the standards development process, and (3) timeliness in the development and implementation of safety standards. 


\section{THE PROBLEM}

Estimated Annual Losses Associated with Consumer Products

o 21,400 Deaths

o 29,400,000 Injuries

o $\$ 200,000,000,000$ in Societal Cost

- 15,000 Different Types of Consumer Products 


\section{CPSC'S VOLUNTARY STANDARDS EXPERIENCE}

o Started in 1973

o Saves Lives; Reduces Serious Injuries

o Saves \$ and Time

o Focuses Expertise 


\section{PARTICIPATION IUEVEL}

FIRE/GAS CODES \& STANDARDS

1. Camping Equipment

2. CO Detectors

3. Gas Water Heaters

4. Unvented Gas Appliances

5. Ranges and Ovens

6. Upholstered Furniture

SPORTS AND RECREATION

7. Bike/Rec. Helmets

8. Soccer Goals

CHILDREN'S PRODUCTS

9. Chairs, Bean Bag

10. Furniture Tipover

11. Playground Equip., Home

12. Playground Equip., Public

13. Playground Equip., Soft

14. Playground Surfacing

15. Window Guards

MECHANICAL CODES \& STANDARDS

16. Pools and Spas

\section{MONITORING LEVEI}

1. Fireworks Devices

ELEC./POWER CODES \& STDS.

2. Christmas Tree/Decor. Lighting

3. Countertop Cooking Appliances

4. Elec. Reinspection

5. Lamps, Portable

6. National Elec. Code

7. Plastic Applications

8. Recharge. Batteries

9. Shock Protection Devices

CHILDREN'S PRODUCTS

10. Activity Centers, stationary

11. Beds, Toddler

12. Blind Cords

13. High Chairs

14. Cribs

15. Infant Bedding

16. Strings in Clothing

17. Toy safety

18. Walkers, Baby

FIRE/GAS CODES \& STANDARDS

19. Furnaces, Central

20. Furnaces,... High Efficiency

21. Gas Systems:

Overpressurization

22. LP Gas Code

23. National Fuel Gas Code

24. 20 1b. Systems, Gas

25. Vented Gas Room Heaters

MECHANICAI CODES \& STANDARDS

26. Escalators

27. Fun-Karts

CHEMICAL HAZARDS

28. ASHRAE IAQ Standards

29. Child Resistant Packaging

30. Lead Abatement 


\title{
THE FUTURE
}

o Continue to Use Voluntary Standards

o Work to Improve:

\author{
- Effectiveness \\ - Use \\ - Openness \\ - Balance \\ - Timeliness
}


SOLVING THE PROBLEM

- Effective, Timely National Consensus Safety Standards

o A Statutory Requirement

- CPSC Provides Injury Information \& Technical Support

o 46 Activities in FY 1997: ANSI, ASTM \& UL 


\section{Section 4}

\section{Regulatory Standards Panel on Energy and Environment}





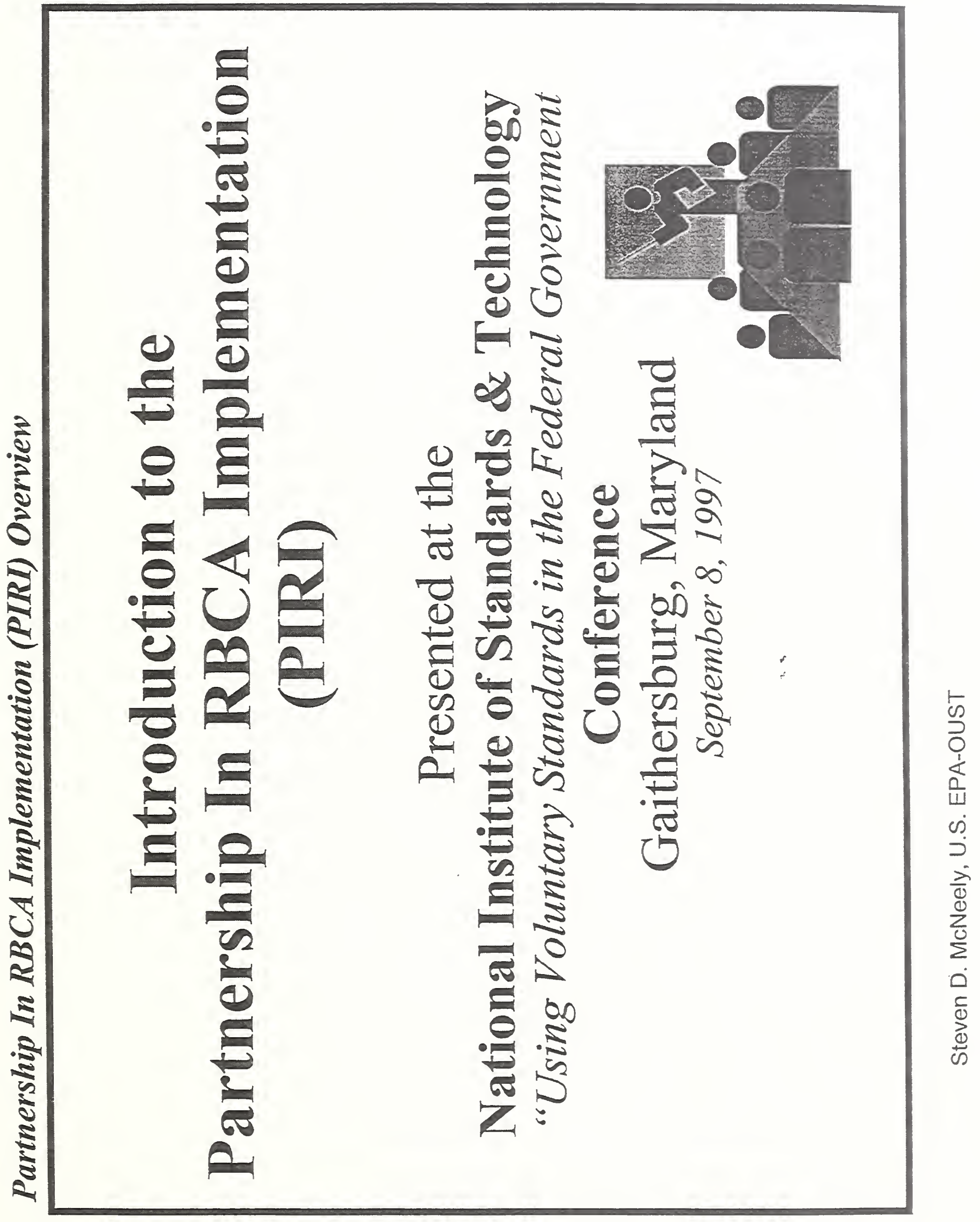




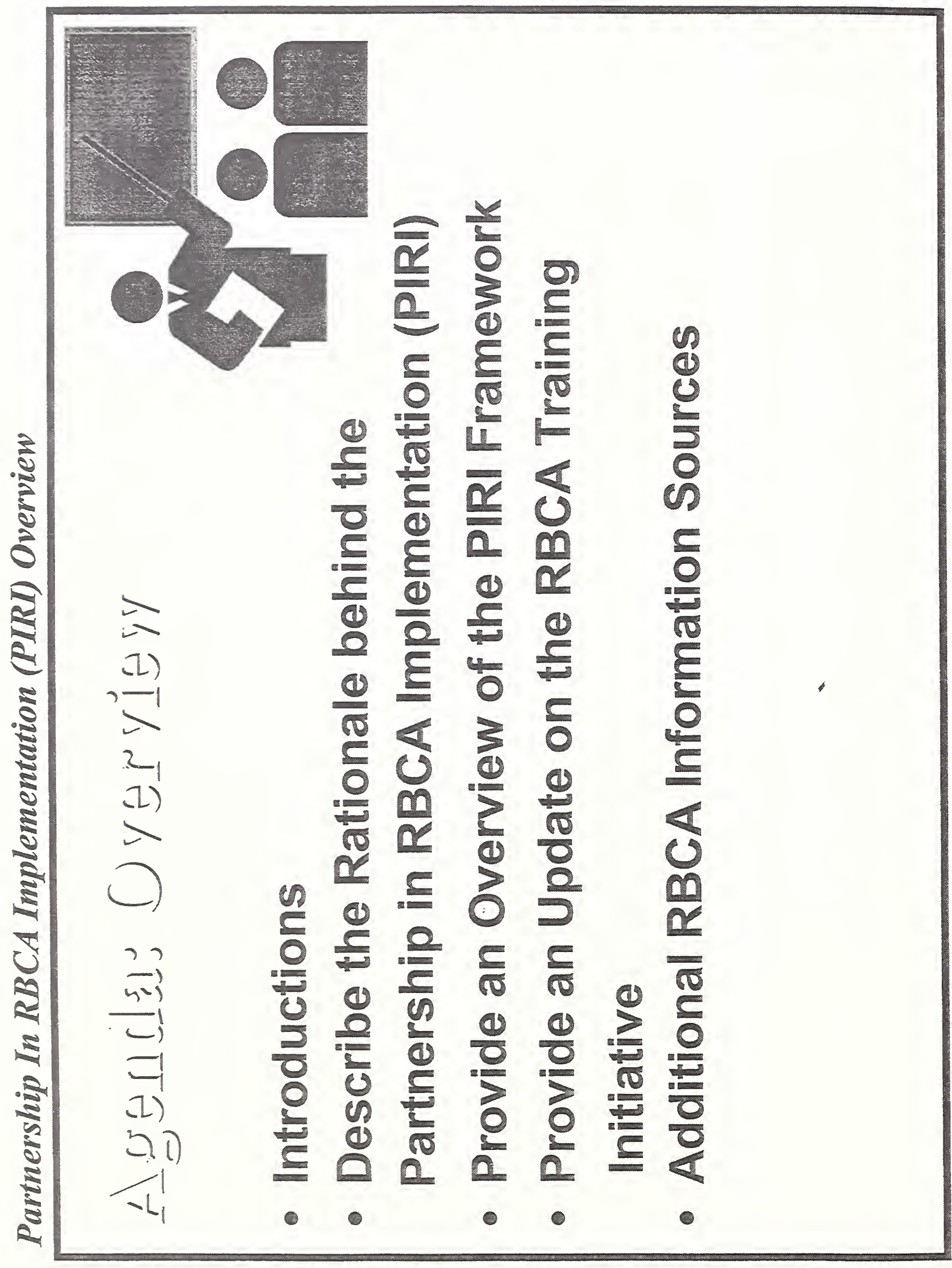




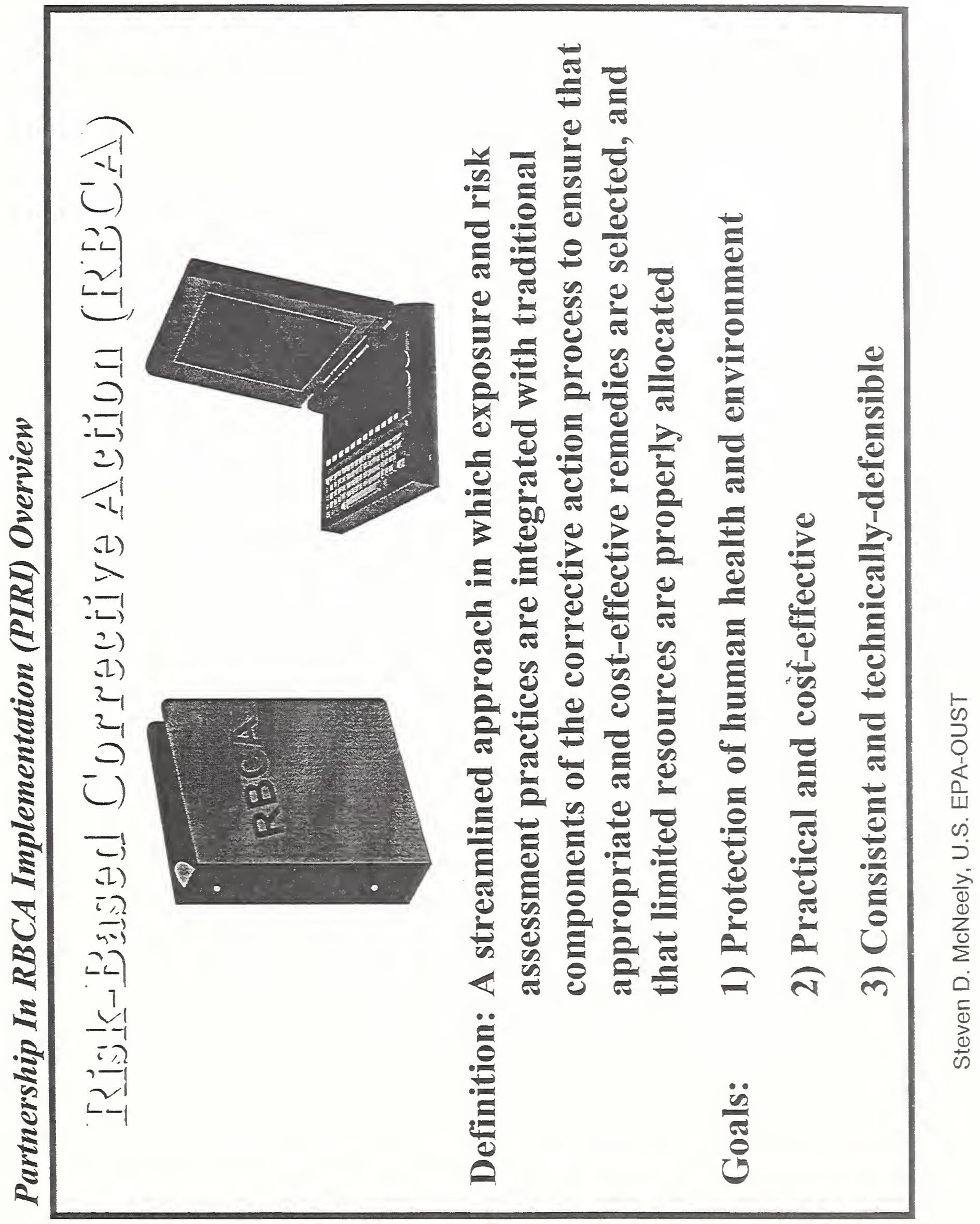




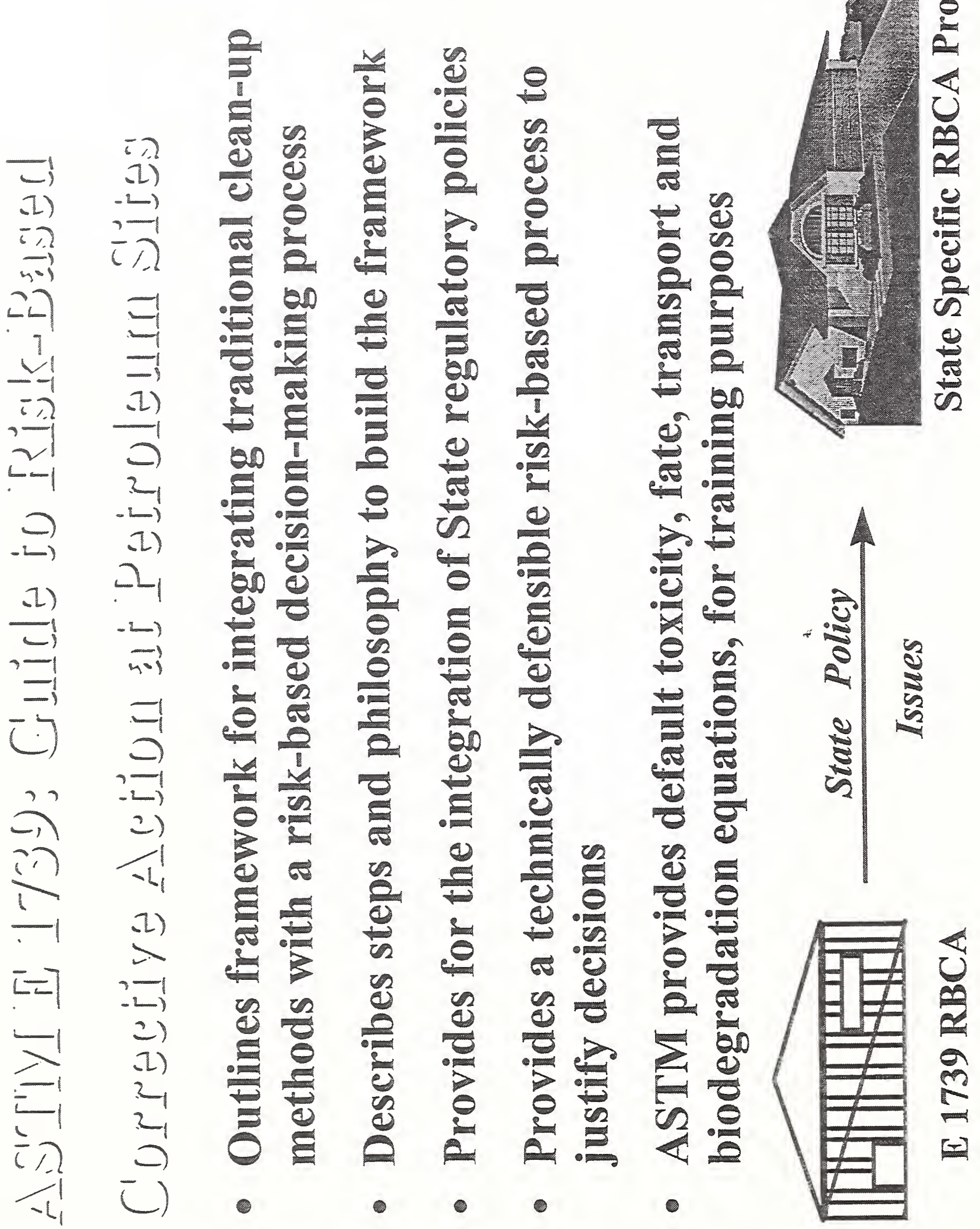




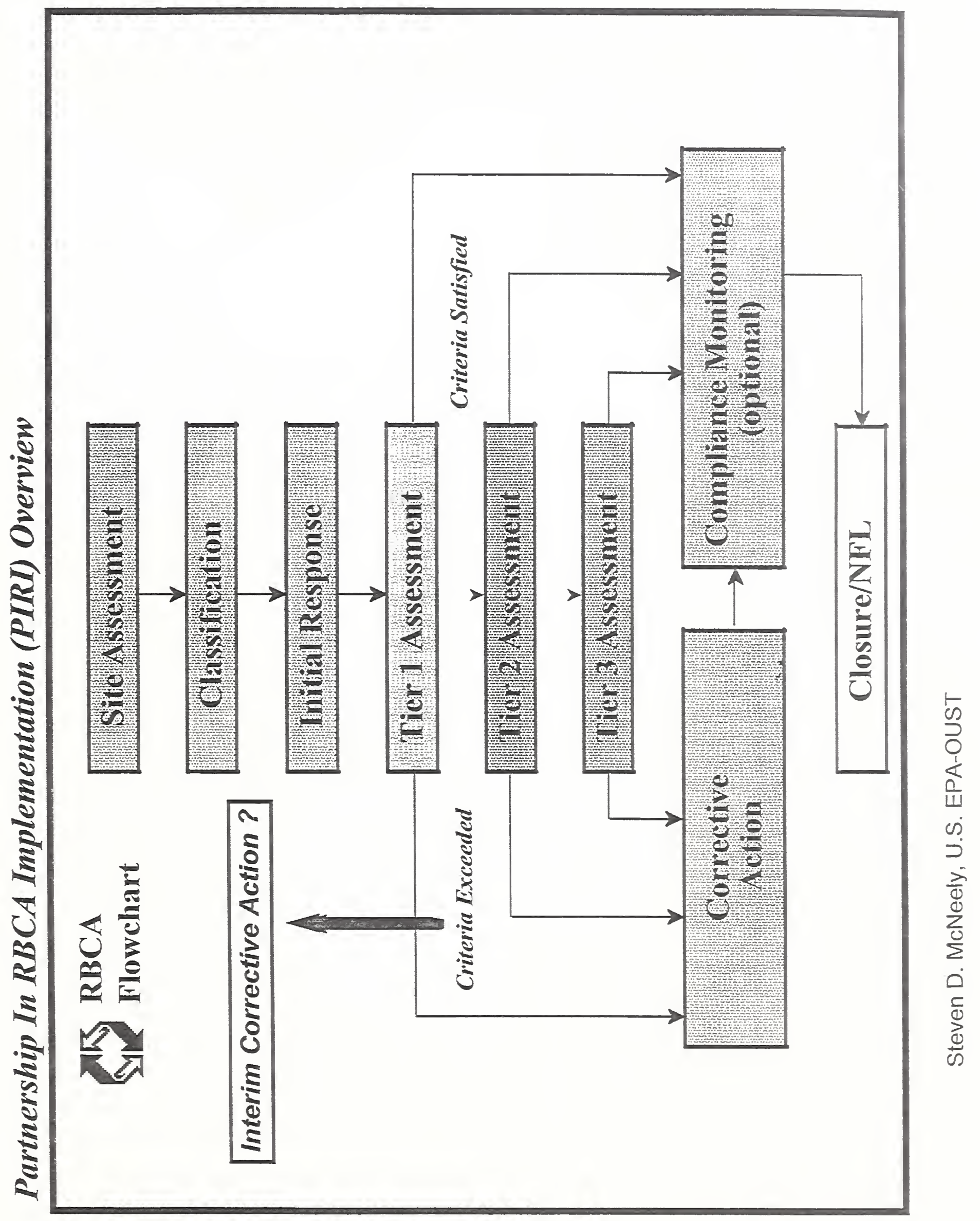


6

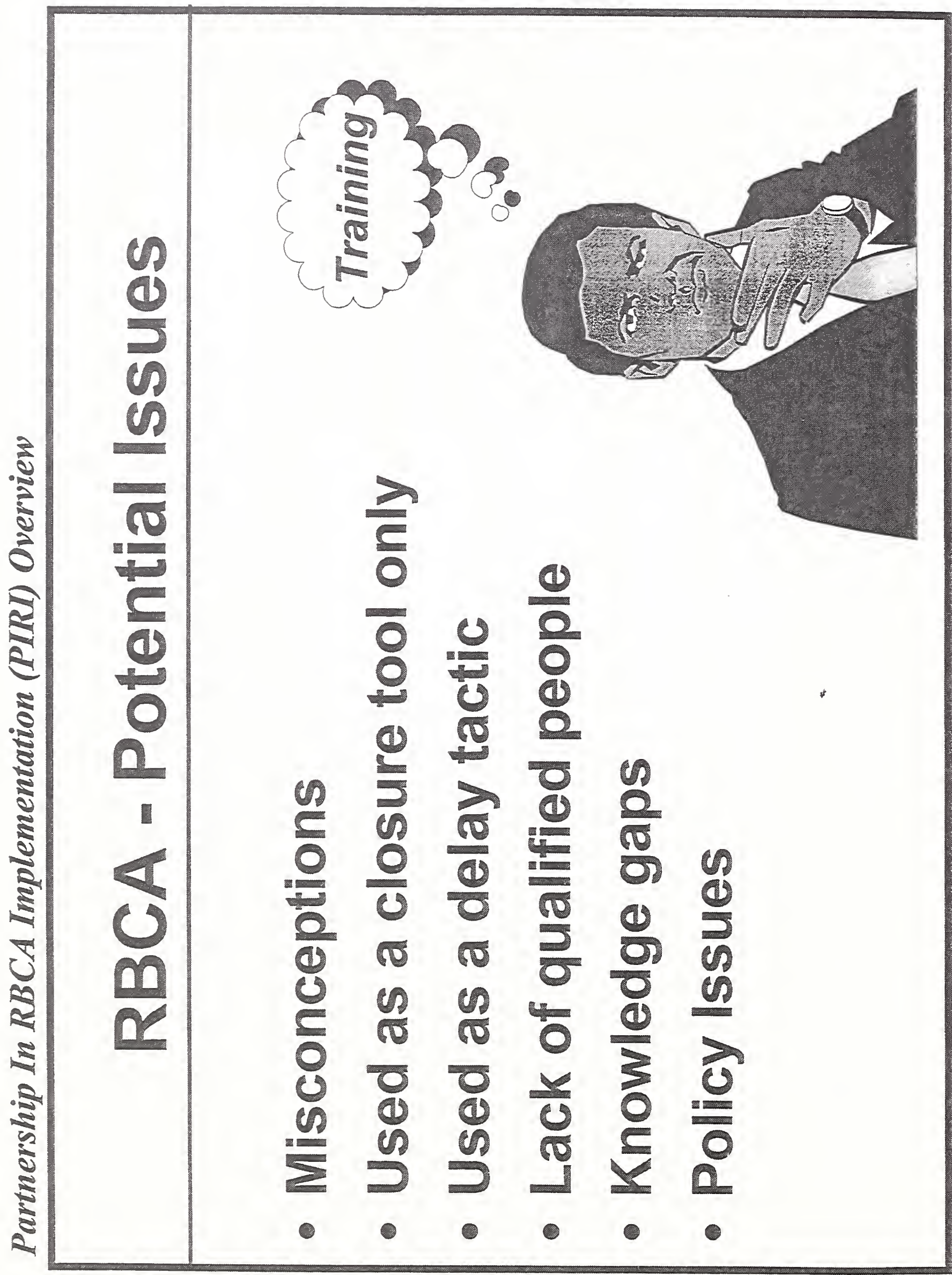

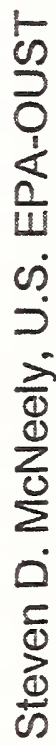




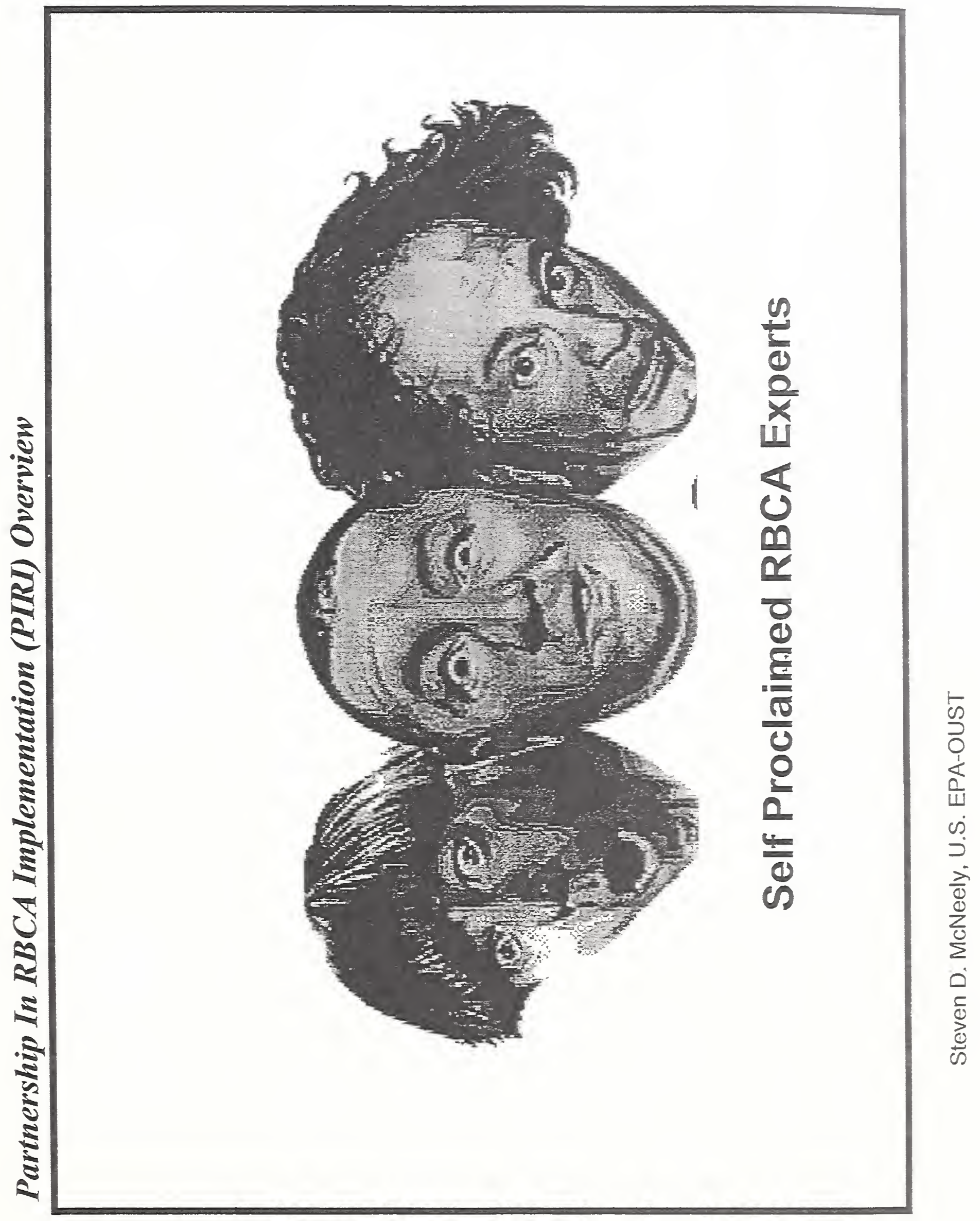




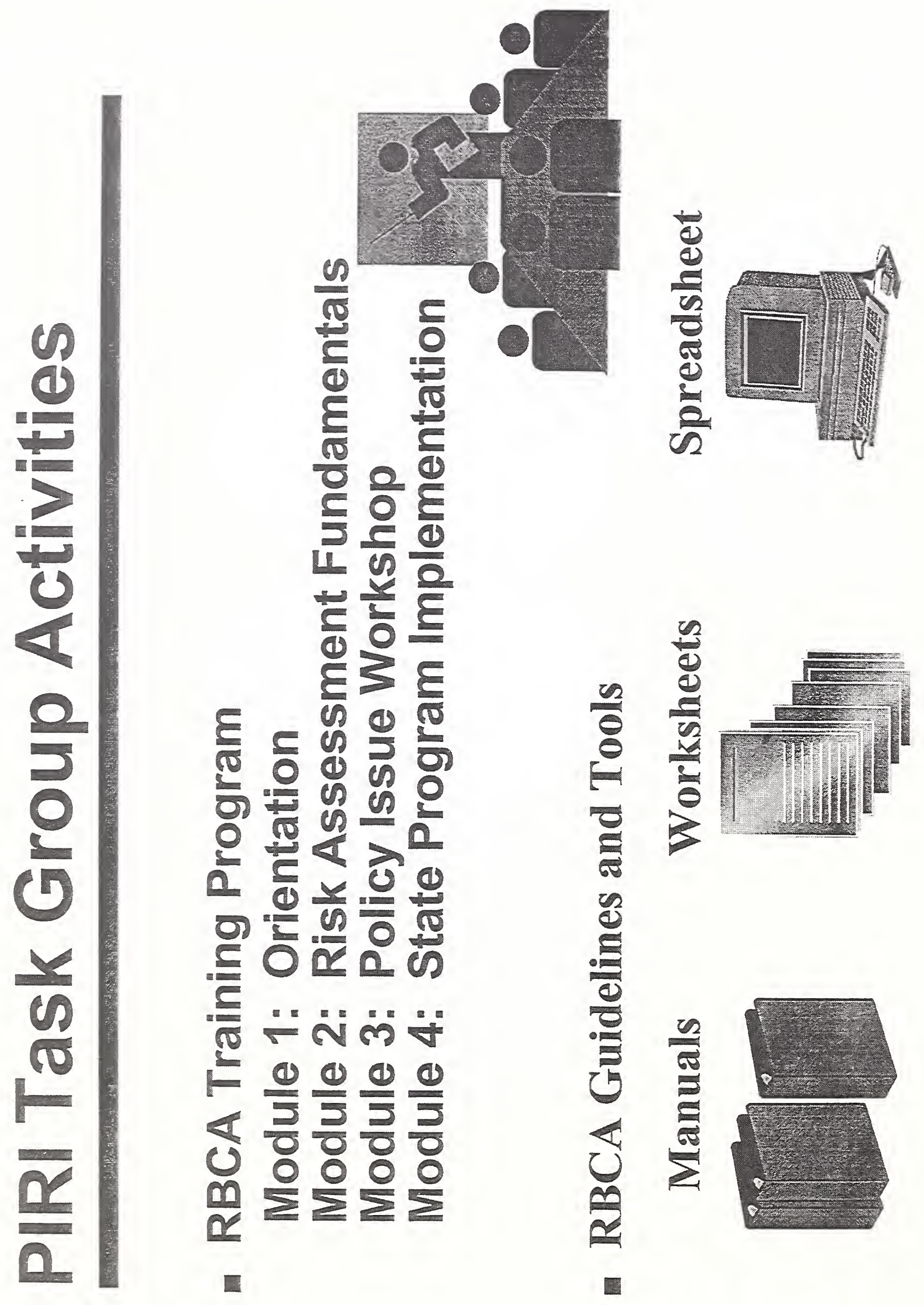




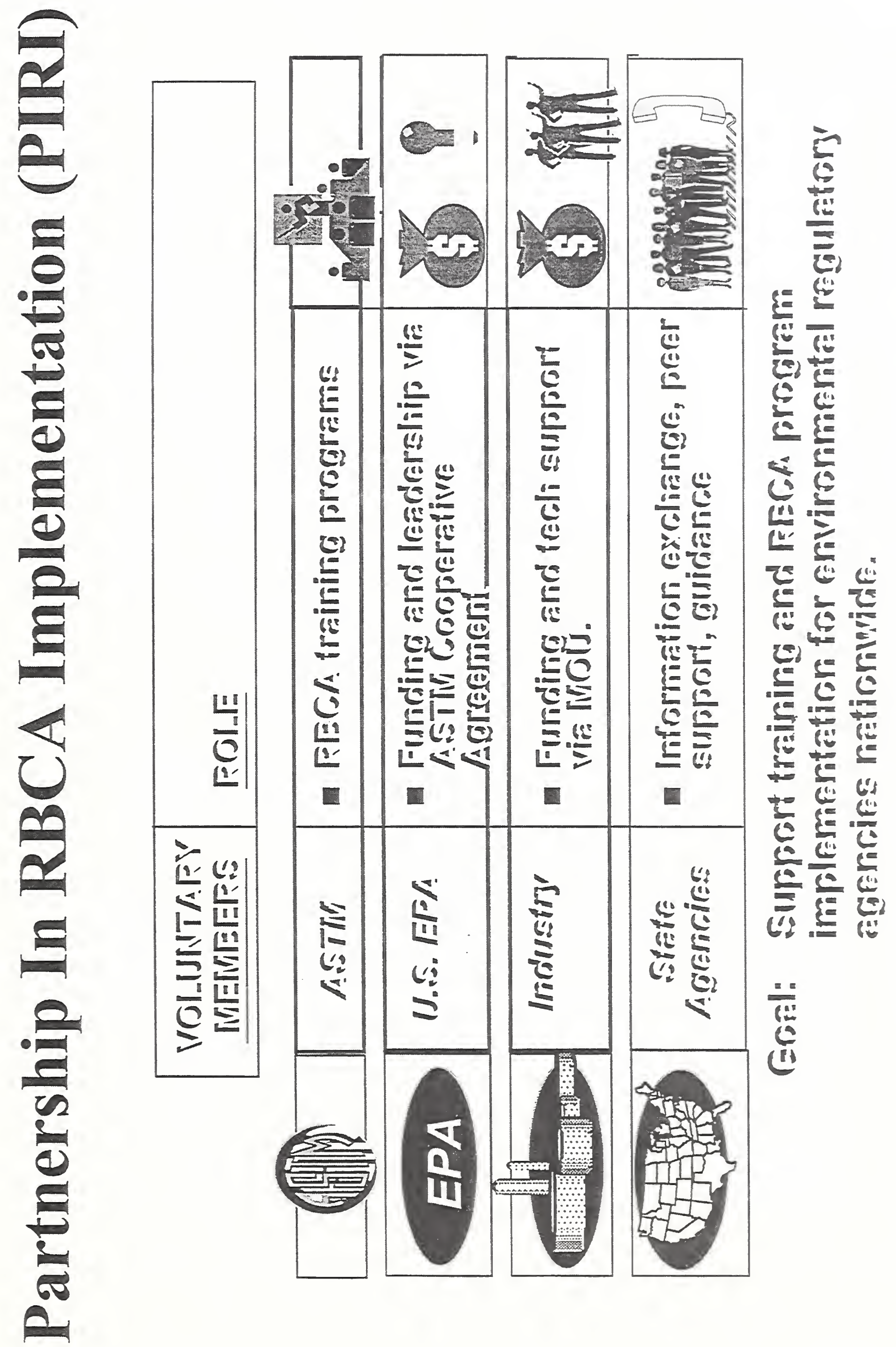




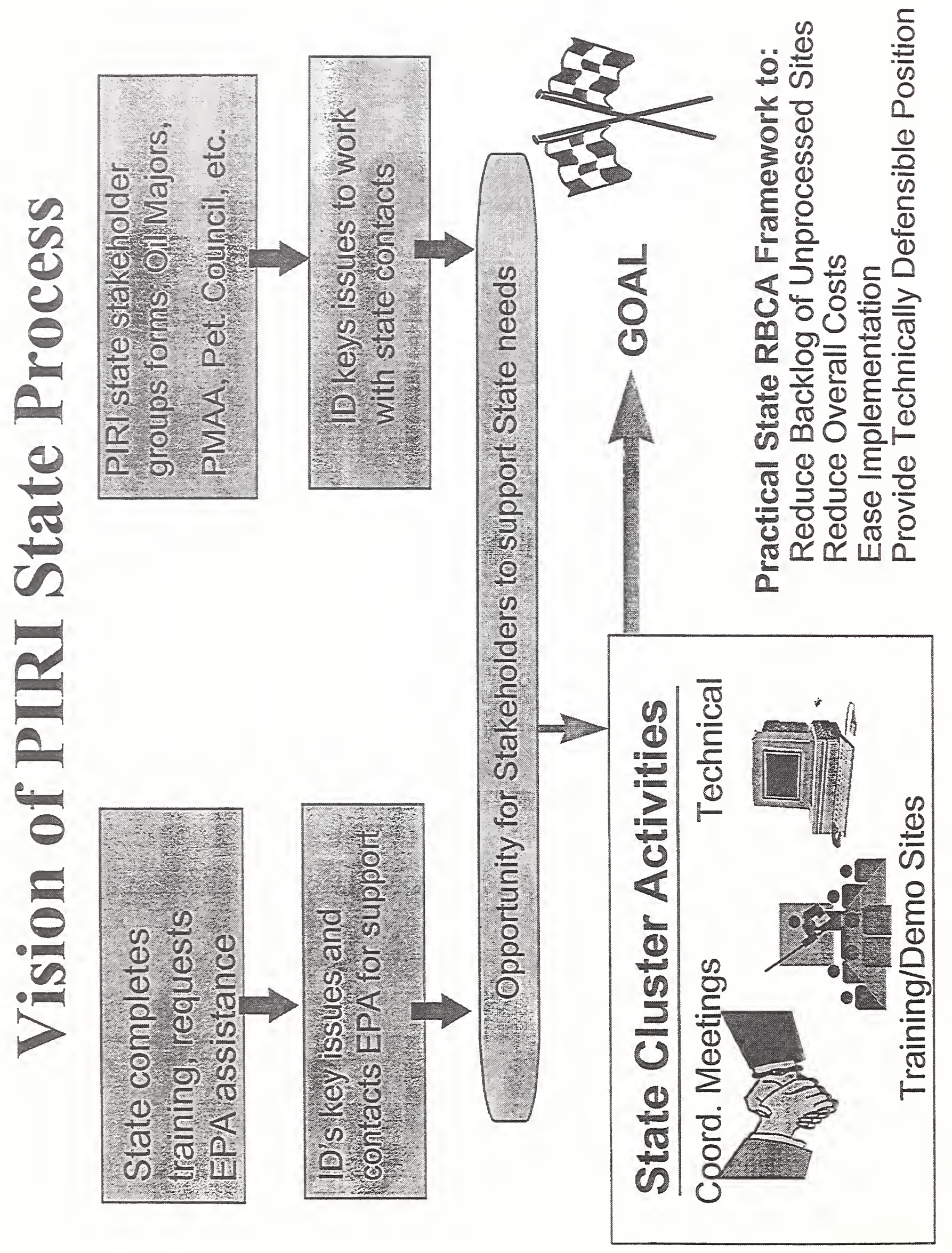




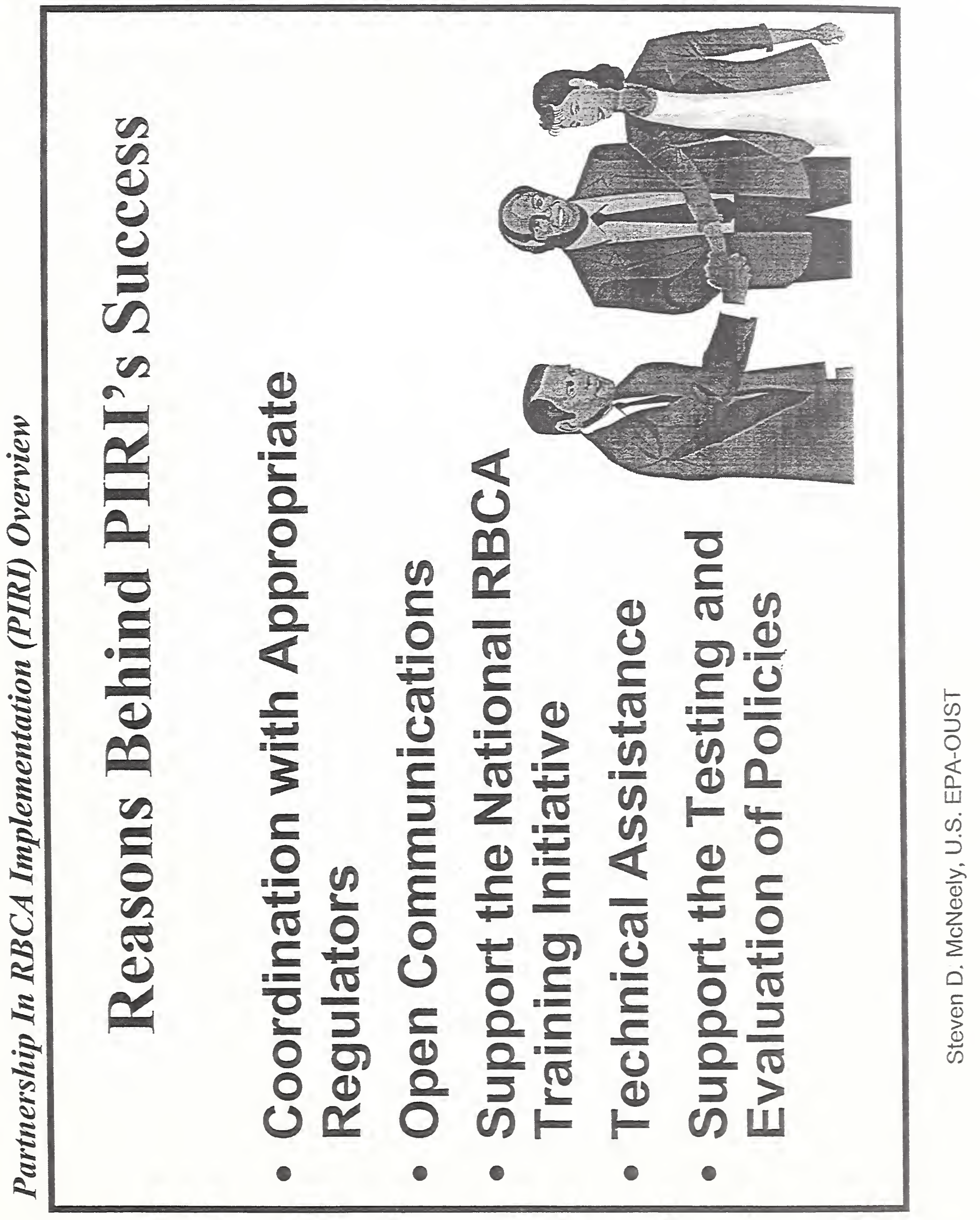




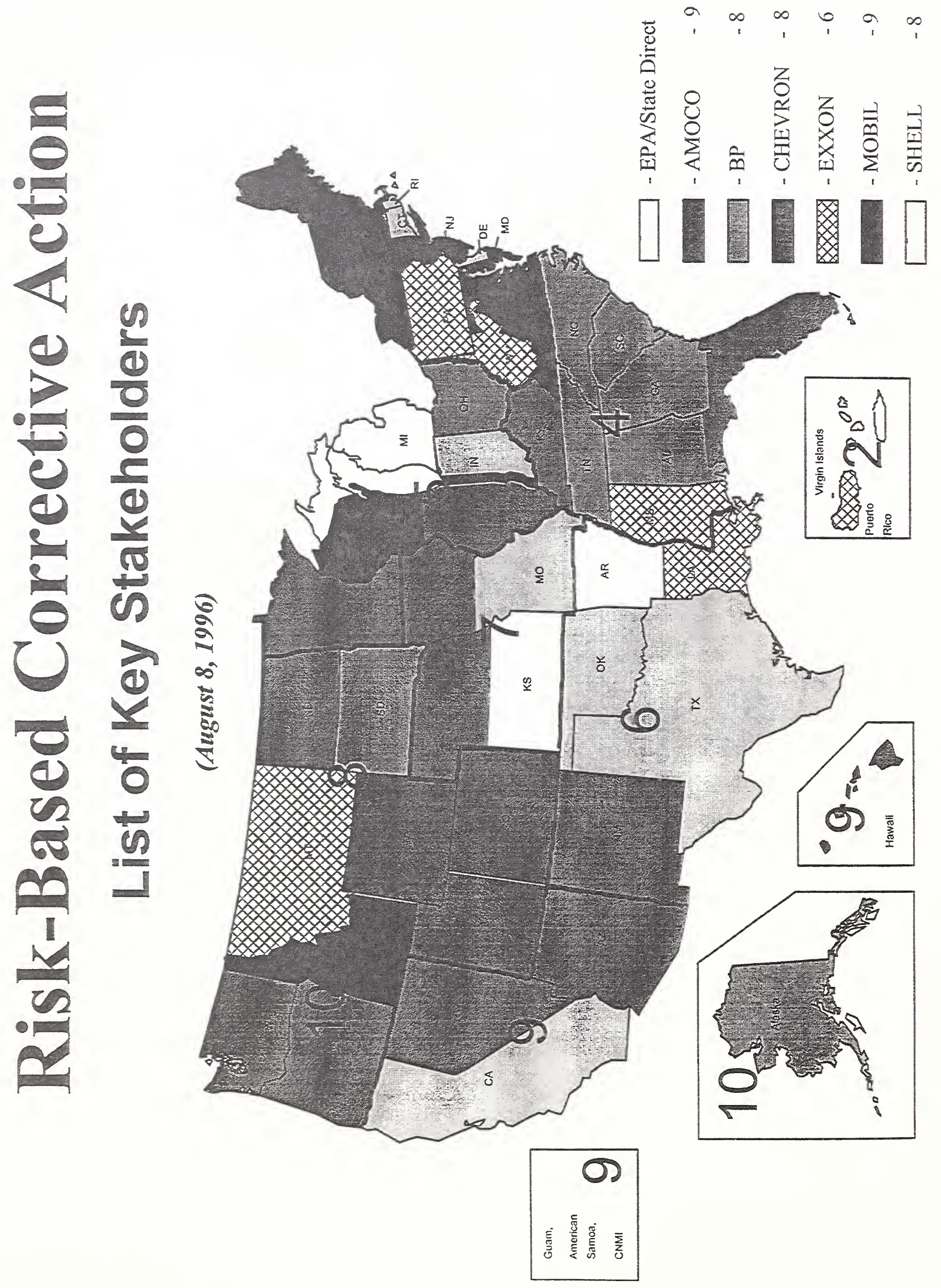



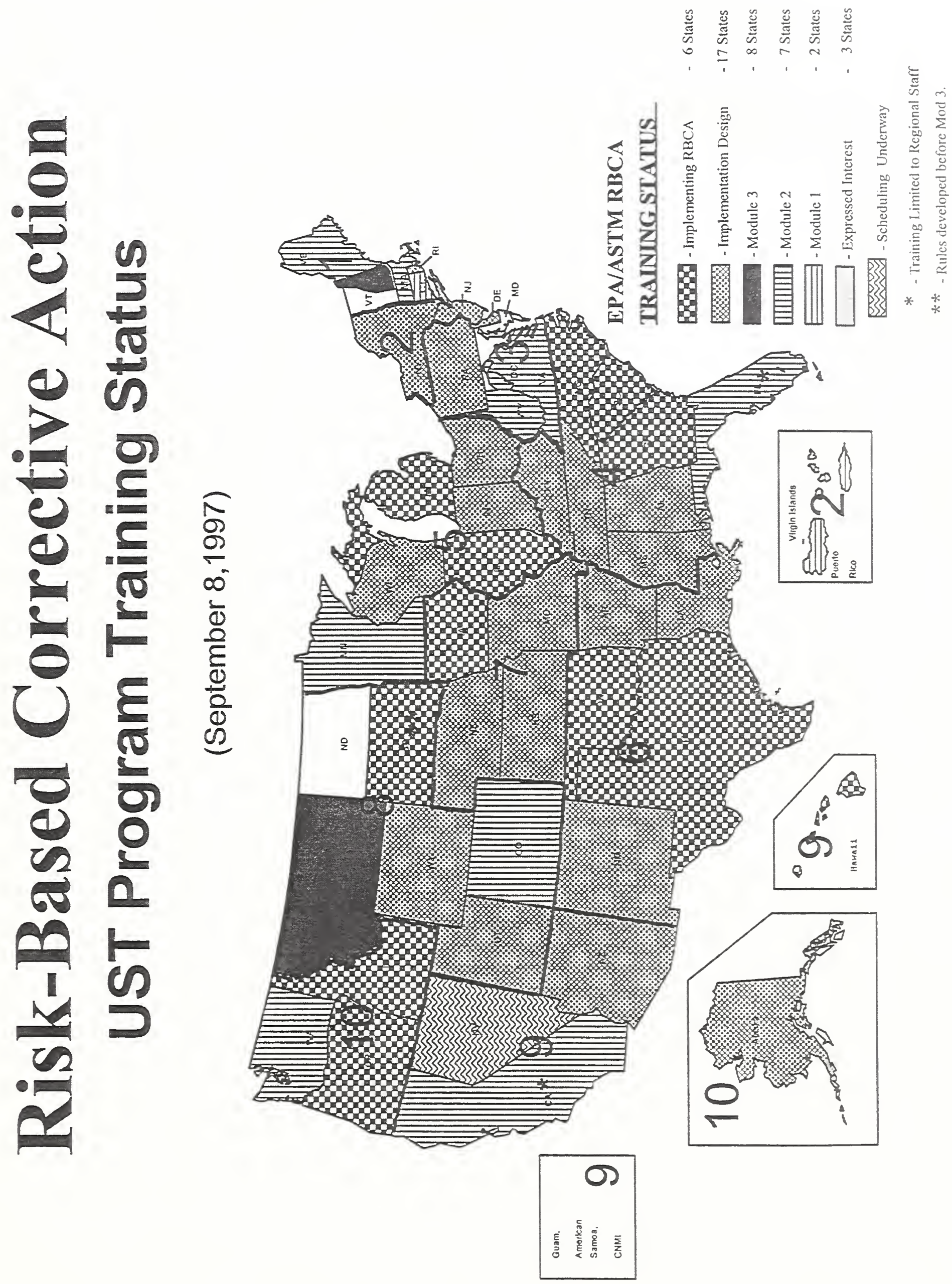


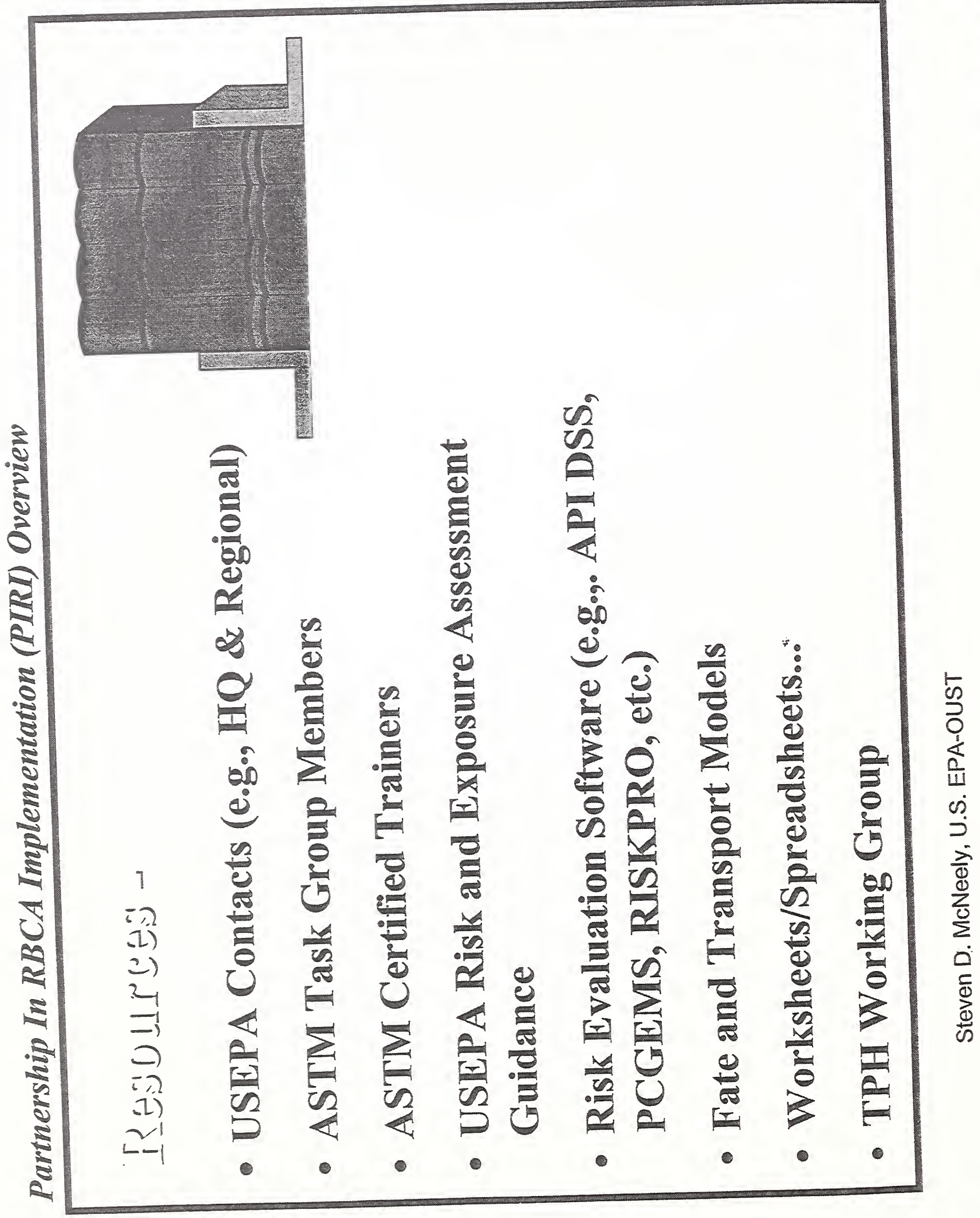




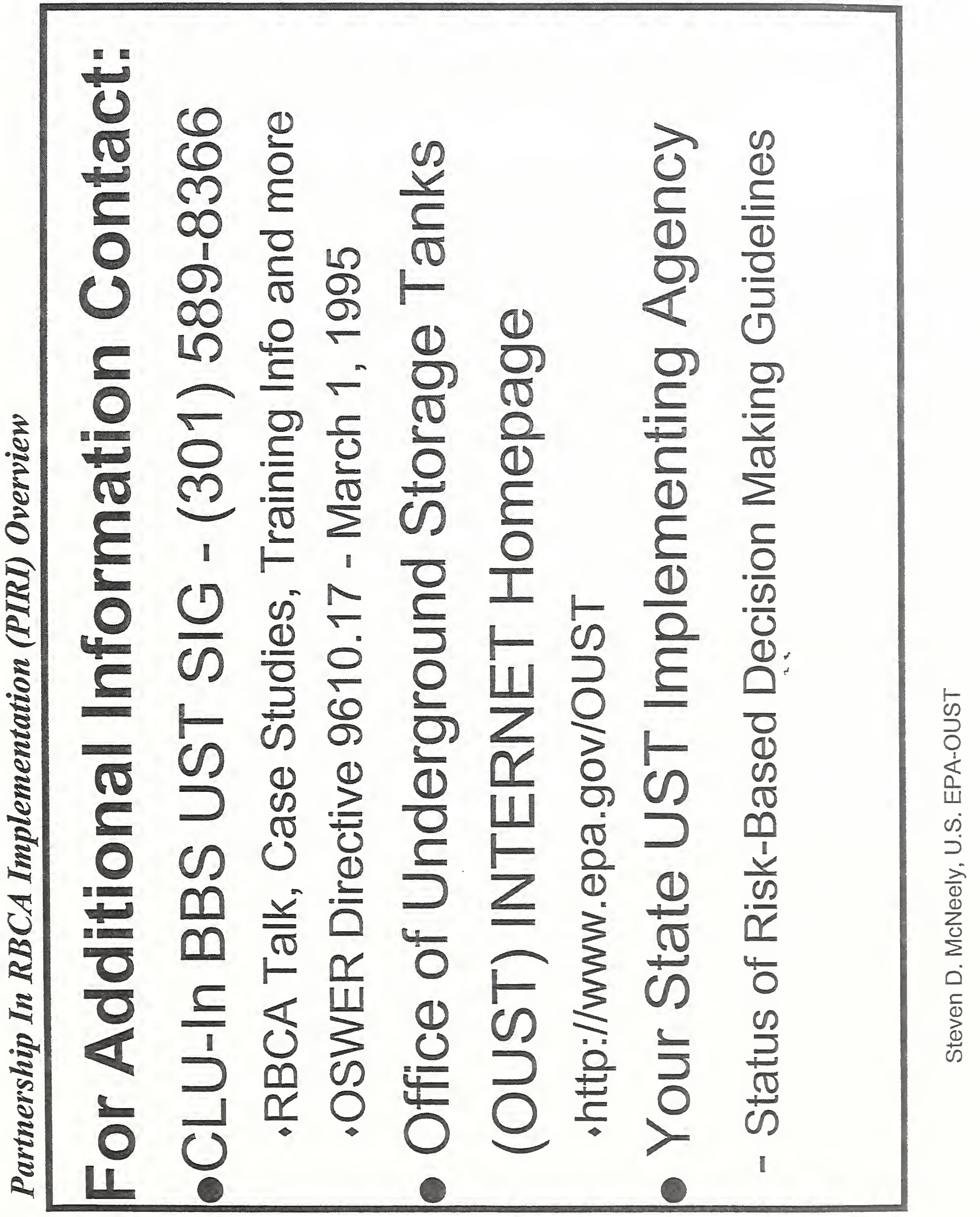




\section{UST Program RBCA Training Summary}

49 States/territories have entered the RBCA scheduling/training loop (i.e., either expressed an interest or actually receiving training assistance). The support provided to each state varies according to their understanding of the risk-based concept and compatibility of their rules/regulations to EPA's RBCA approach. The breakout includes:

\section{We are actively working with 49 states/territories}

34 States are in the implementation phase (i.e., completed Module 3 and are developing and/or refining administrative practices to foster RBCA's use).

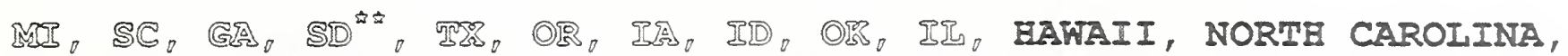
Louisiana, Alabama, New York, Utah, Ohio, New Jersey, Indiana, Nebraska, Tennessee, Rentucky, Pennsylvania, Mississippi, Arkansas, Kansas, New Mexico, Arizona, Missouri, Delaware, Wyoming, Rhode Island, Alaska and, Wisconsin

4 States/territories are scheduled to complete Module 3 soon or previously completed Module 3 , and could proceed to the implementation design phase.

Montana, New Hampshire, Puerto Rico and, Virgin Islands.

11 States/territories received Module $1 \& 2$ training but have not continued to Module 3.

Virginia, West Virginia, Minnesota, Massachusetts, Washington, Connecticut, Colorado, Florida*, California*, the District of Columbia \& Maine.

1 aditional State has expressed interest in obtaining either ASTM RBCA trairing \&/or implementation assistance:

\section{IEGEND:}

\section{Nevada}

\footnotetext{
* = A comprehensive RBCA training schedule is being developed for each of the respective District and/or regional water boards (designated implementing agencies).

= The state skipped Module 3 training and subsequent evaluations (i.e., site demonstrations) to promulgate RBCA guidance documents and/or legislation.

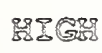

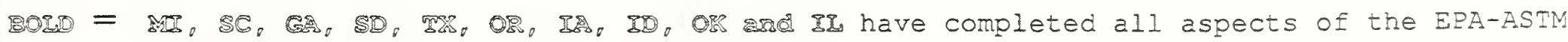
RBCA training, issued guidance manuals, and are implementing a RBCA process customized for use in their state.
}

BOLD

UPPERTASTI = The state developed and issued their RBCA process prior to or in lieu of obtaining comprehensive ERA ASTM RBCA Training. Technical - implementation. assistance may be provided in lieu of the comprehensive RBCA training.

NOTE: The information provided in this graphic/narrative does not provide an accurate summary of the use of risk-based decision making (RBDM) in all states. This summary PRIMPRIIY provides information on the status of ASTM RBCA training in the UST program. Numerous States have established RBDM programs other than ASTM's RBCA. 


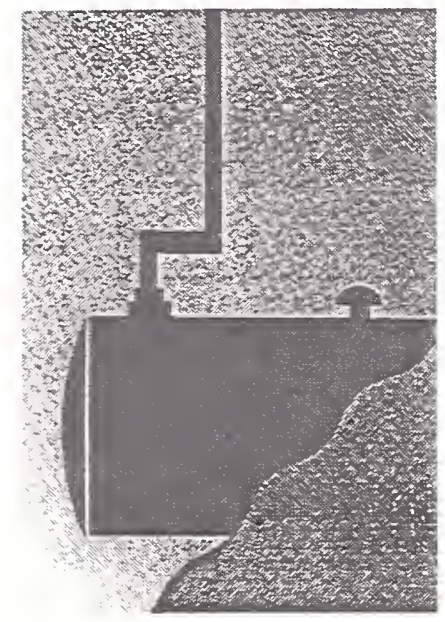

\title{
PIR/ Issue Papers
}

EPA Number 510-R-97-001

\author{
A collection of technical issue papers written by \\ EPA, state, and industry members of the \\ Partnership In RBCA Implementation
}

\section{What are the "PIRl" papers?}

The Partnership In RBCA Implementation (PIRI) is a collaboration of industry, states, EPA and ASTM. The partnership was established to encourage and support state efforts to implement a risk-based approach to corrective action at federally regulated UST sites involving releases of petroleum or petroleum products. In a series of papers they have authored, individual PIRI members discuss issues involved in implementing RBCA and present options for overcoming obstacles.

\section{What issues are covered?}

The papers discuss RBCA issues associated with natural attenuation; the definition of "contaminant;" "No Further Action" letters; selection of carcinogenic target risk levels for soil and groundwater remediation; off-site movement of chemicals of concern; institutional controls; groundwater nondegradation policies; and using TPH. All papers represent only the views of their authors; they do not reflect official EPA policy or the positions of PIRI member organizations.

\section{How can I get a copy?}

EPA has posted the PIRI Issue Papers on the Office of Underground Storage Tanks World Wide Web site at http://Www.epa.gov/OUST/rbdm/piriacts.htm. You are free to read the papers on-line, or download them. If you do not have Internet access, you may order a copy of the Papers by calling the National Center for Environmental Publications and Information (NCEPI) toll-free at 1-800-490-9198. 


\begin{tabular}{|c|c|c|c|c|c|}
\hline \multicolumn{6}{|c|}{ Tentative List of Key Stakeholders (pending approval by States) } \\
\hline Shell: & $\begin{array}{c}\frac{\text { Connecticut }}{\text { California }} \\
\frac{\text { Rhode Island }}{\text { Texas }} \\
\text { Indiana } \\
\text { Missouri } \\
\text { Delaware } \\
\text { Oklahoma }\end{array}$ & Total: 8 States & EPA: & $\frac{\text { Michigan }}{\text { Kansas }}$ & Total: 3 States \\
\hline Amoco: & $\begin{array}{c}\underline{\text { Iowa }} \\
\underline{\text { Illinois }} \\
\text { New Jersey } \\
\text { Minnesota } \\
\text { Colorado } \\
\text { Nebraska } \\
\text { Wyoming } \\
\text { Florida } \\
\text { Utah }\end{array}$ & Total: 9 States & & & \\
\hline Mobil: & $\begin{array}{l}\frac{\text { New York }}{\text { Idaho }} \\
\text { Wisconsin } \\
\text { Virginia } \\
\text { Massachusetts } \\
\text { Maryland } \\
\text { Maine } \\
\text { Vermont } \\
\text { New Hampshire }\end{array}$ & Total: 9 States & & & \\
\hline Exxon: & $\begin{array}{c}\text { Louisiana } \\
\text { Montana } \\
\text { Pennsylvania } \\
\text { West Virginia } \\
\text { Washington, DC } \\
\text { Mississippi } \\
\text { Puerto Rico }\end{array}$ & Total: 6 States \& PR & & & \\
\hline BP: & $\begin{array}{c}\frac{\text { South Carolina }}{\text { Ohio }} \\
\frac{\text { Georgia }}{\text { Alaska }} \\
\frac{\text { Tennessee }}{\text { North Carolina }} \\
\frac{\text { South Dakota }}{\text { Alabama }}\end{array}$ & Total: 8 States & & & \\
\hline Chevron: & $\begin{array}{c}\text { Kentucky } \\
\text { Washington } \\
\text { Arizona } \\
\text { Nevada } \\
\text { North Dakota } \\
\text { New Mexico } \\
\text { Oregon } \\
\text { Hawaii }\end{array}$ & Total: 8 States & & & \\
\hline
\end{tabular}

Underlined States represent States where company is already acting as "Sponsor". 


\section{PIRI Key Stakeholder Contacts}

NOTE: Contact your EPA Regional RBCA Contact to get in touch with your PIRI Key

Stakeholder

Amoco Corporation: Geoffrey Gilman

Shell Oil Company: Wayne Hamilton

Chevron Products Company: Jeff Hartwig

Mobil Oil Corporation: Mark W. Malander

British Petroleum: Jim Rocco

Lesley Hay Wilson

Exxon: $\quad$ Len M. Racioppi 


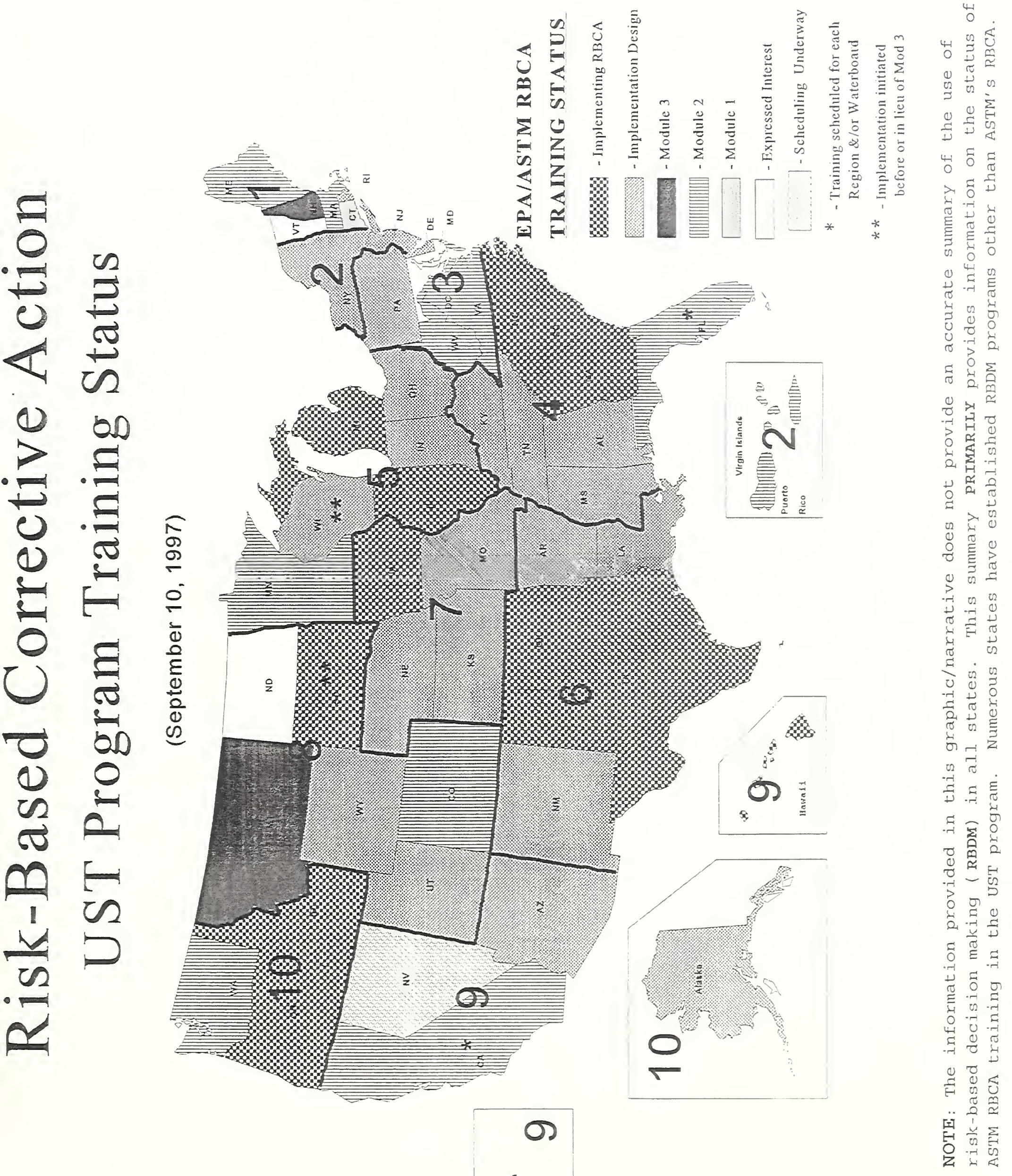






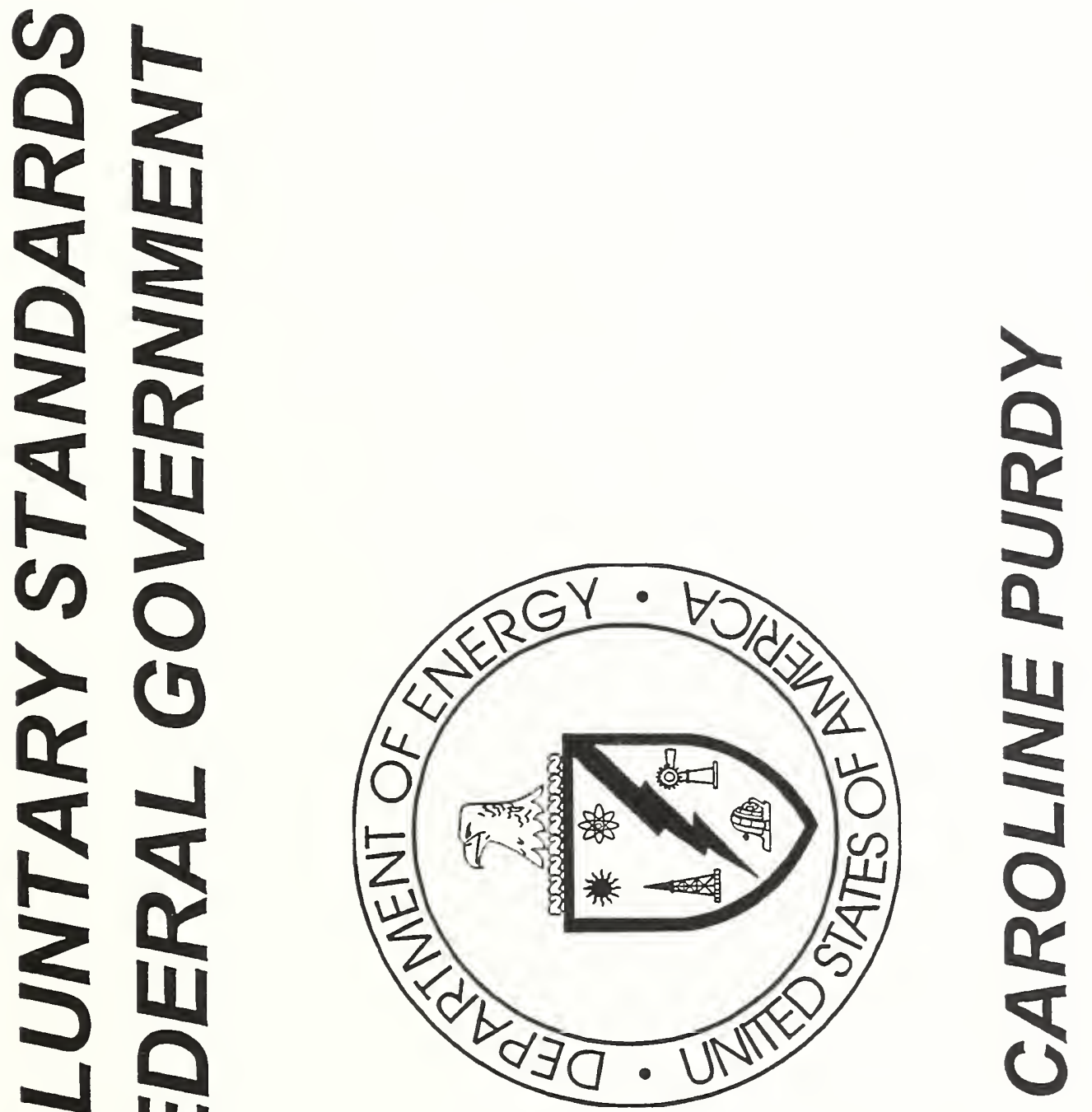

1

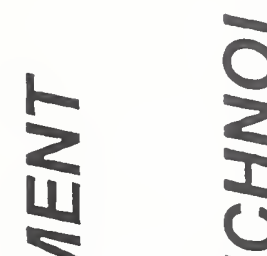

$N$

$\frac{1}{1}$ os

U1 -

If $\infty$

DC

$\longrightarrow$

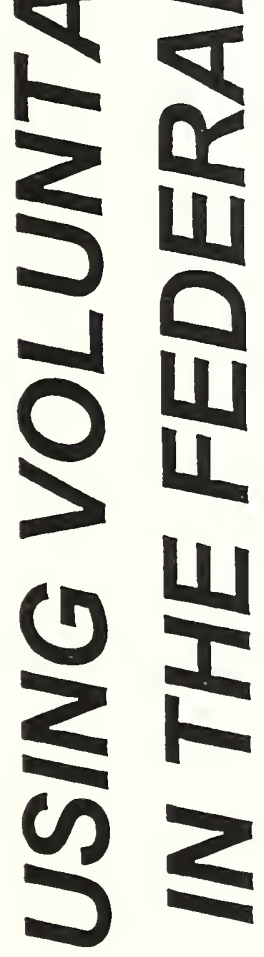

$\frac{1}{2} \geqslant \frac{\alpha}{2}$

0

아 2

$\tau m$

$\infty$ U

4I $\sim$ K

$4 \leqslant$ है

$\leqslant$ U $之 \infty$

W $\sum_{0} \quad \frac{k}{\omega}$

$E \leqslant$

40

र $\sum$ ए

a.

$\frac{4}{\frac{4}{4}}$

$\equiv \infty$

0

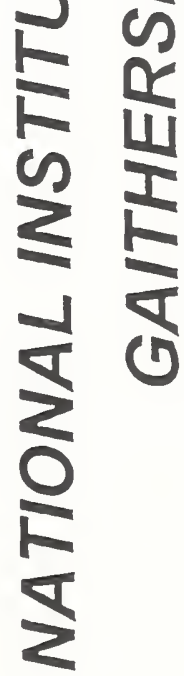




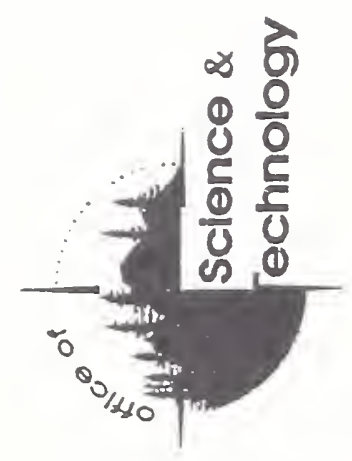



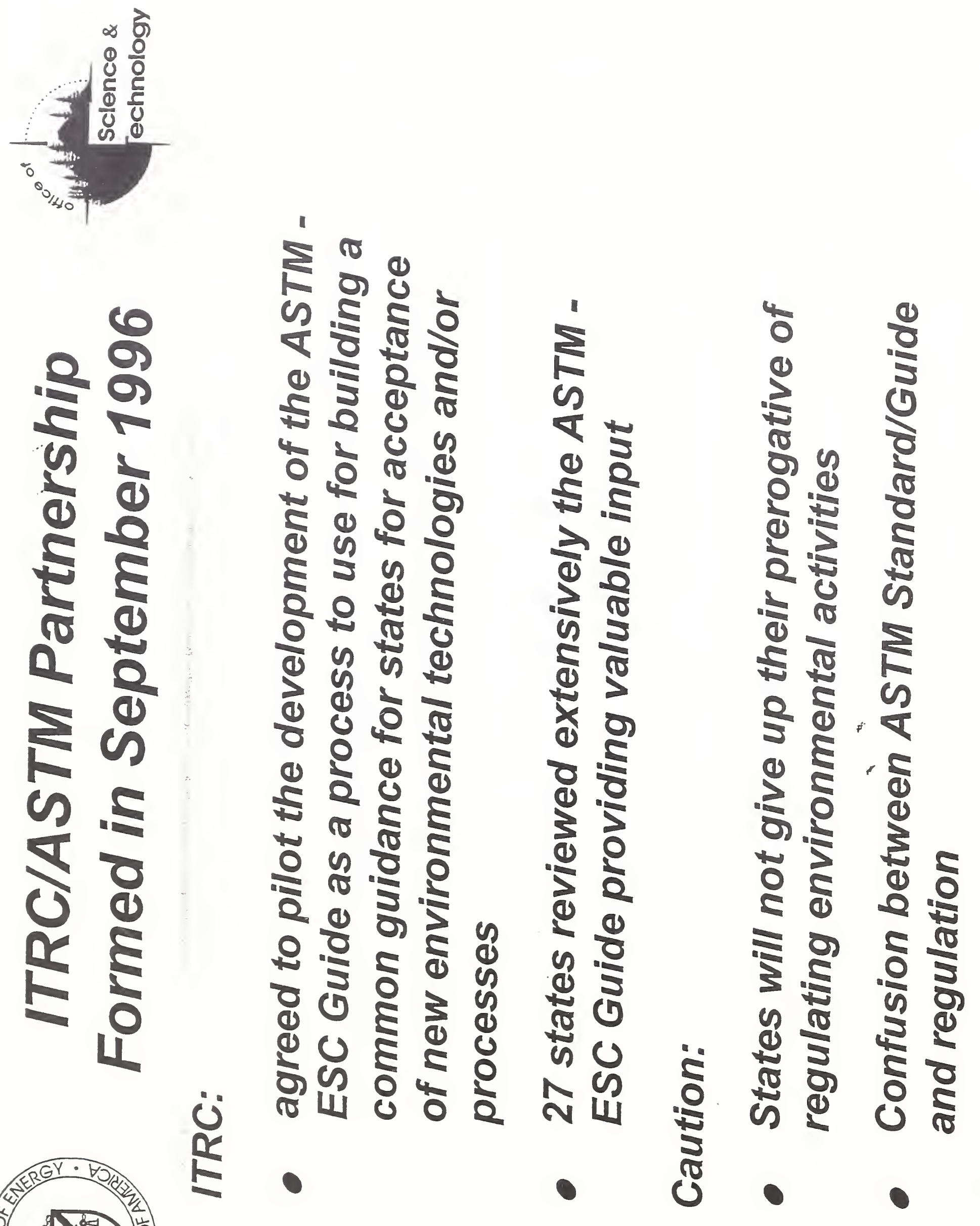

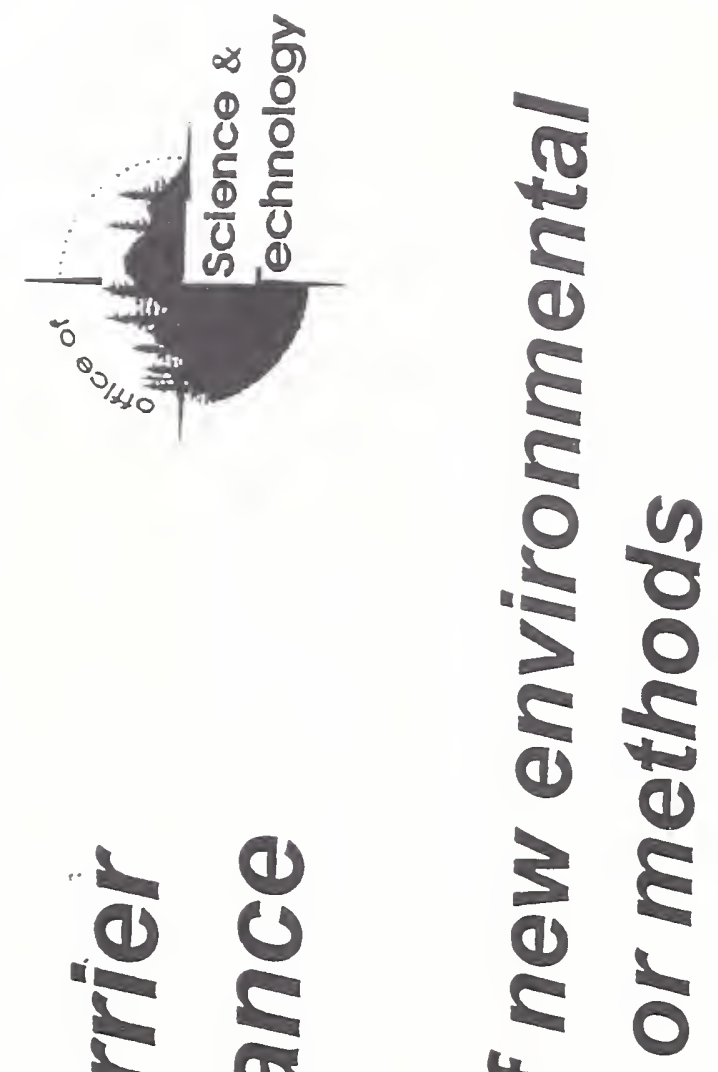

ib 5 a 5 a 5

190

$90 \div$

$00 \frac{0}{a}$

( 5

(1) (1)

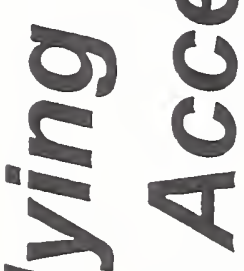

$\leqslant 0$

(4)

世

5 .

(b)

(3) 5

10 o

$\geqslant \frac{1}{0}$

00

100

$\infty 5$

(1)

(a) 6

a 4
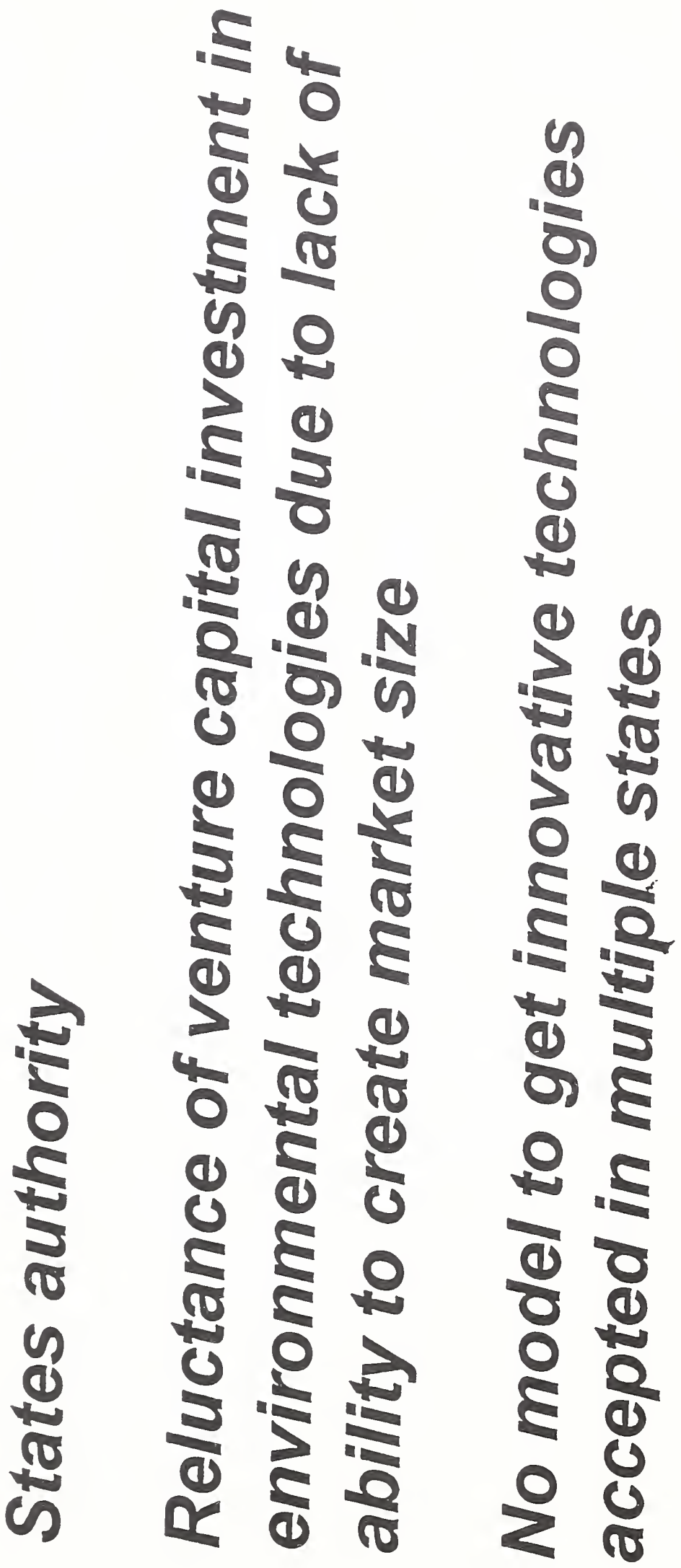


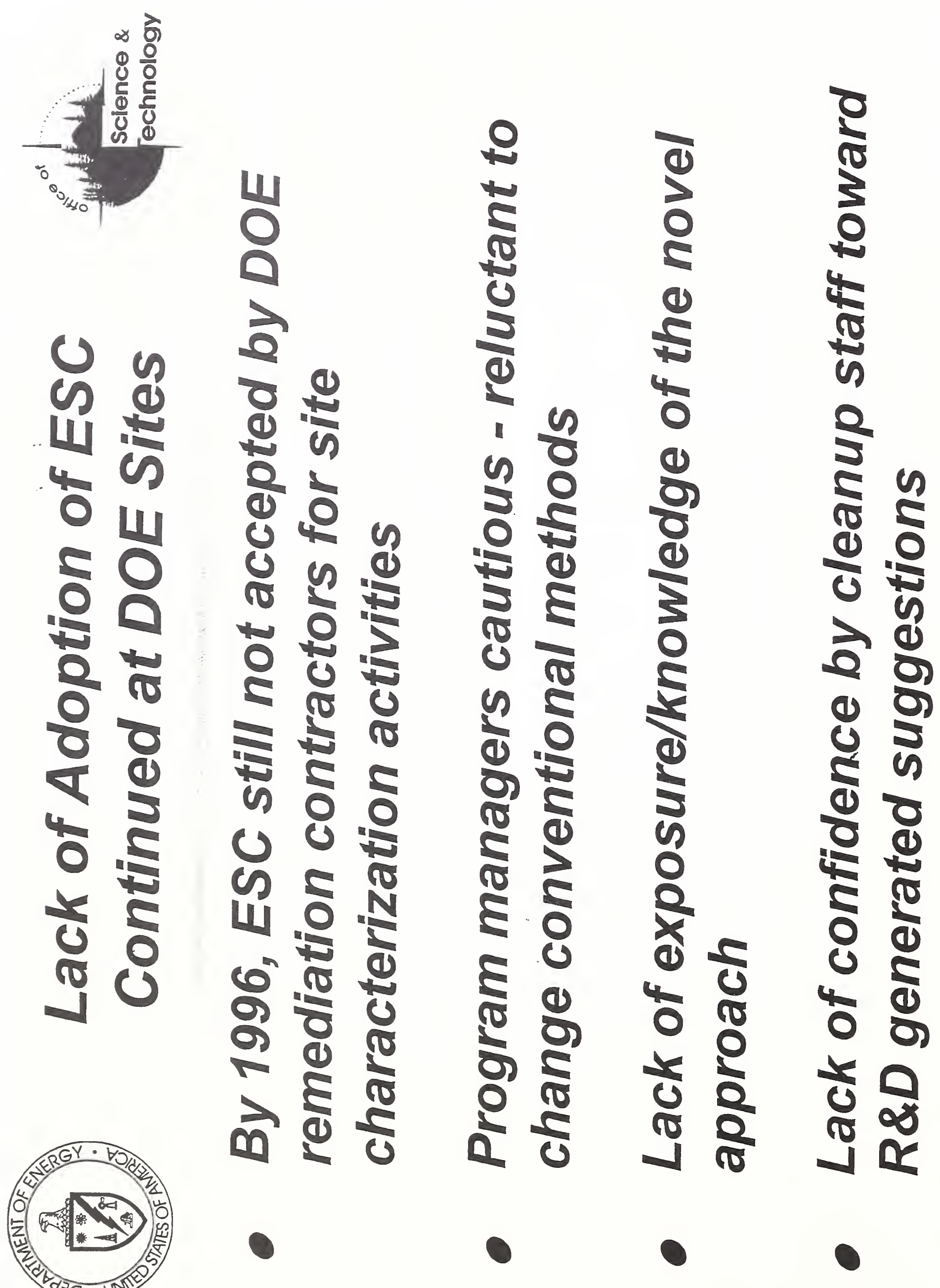




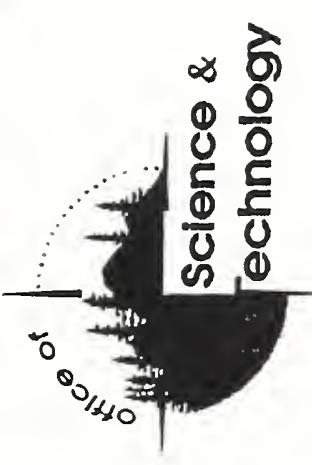

10

$\frac{0}{10}$

2

(a)

(1) 10

0

E 10

(1)

1

-

(1)

24

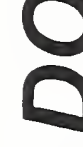

$+$

$E 0$

$\frac{1}{10}$

(1) 10

101

(1)

21

20

$\nabla *$

(1) 0

$\infty$

山

5

c

5

o

$\xi$

(1)

8

$\pi$

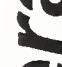

(1)

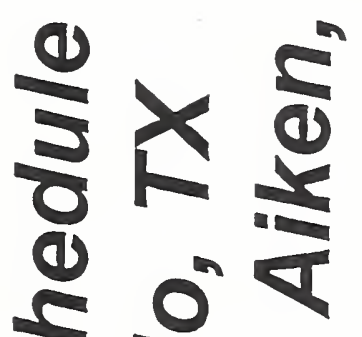

$\circlearrowleft$

2

ฏ)

ฮ)

일

(1)

(1)

0

5

2 ह

ते रे बे

* 3

क स

प $\frac{\pi}{2}$

0

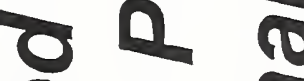

$\Phi x \leqslant$

일

(ब)

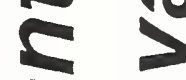

$\varepsilon \frac{\pi}{\pi}$

Q

U

()

\&

(1)

$\sum_{0} \frac{\pi}{5}$

ल ज

ค

ㅇํ

(1) $\frac{1}{2}$

$\theta \pi$

ह $\leqslant$

(

- $\frac{1}{\pi}$

ฮ

\&

ब

ह

$-1$

00

04

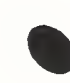



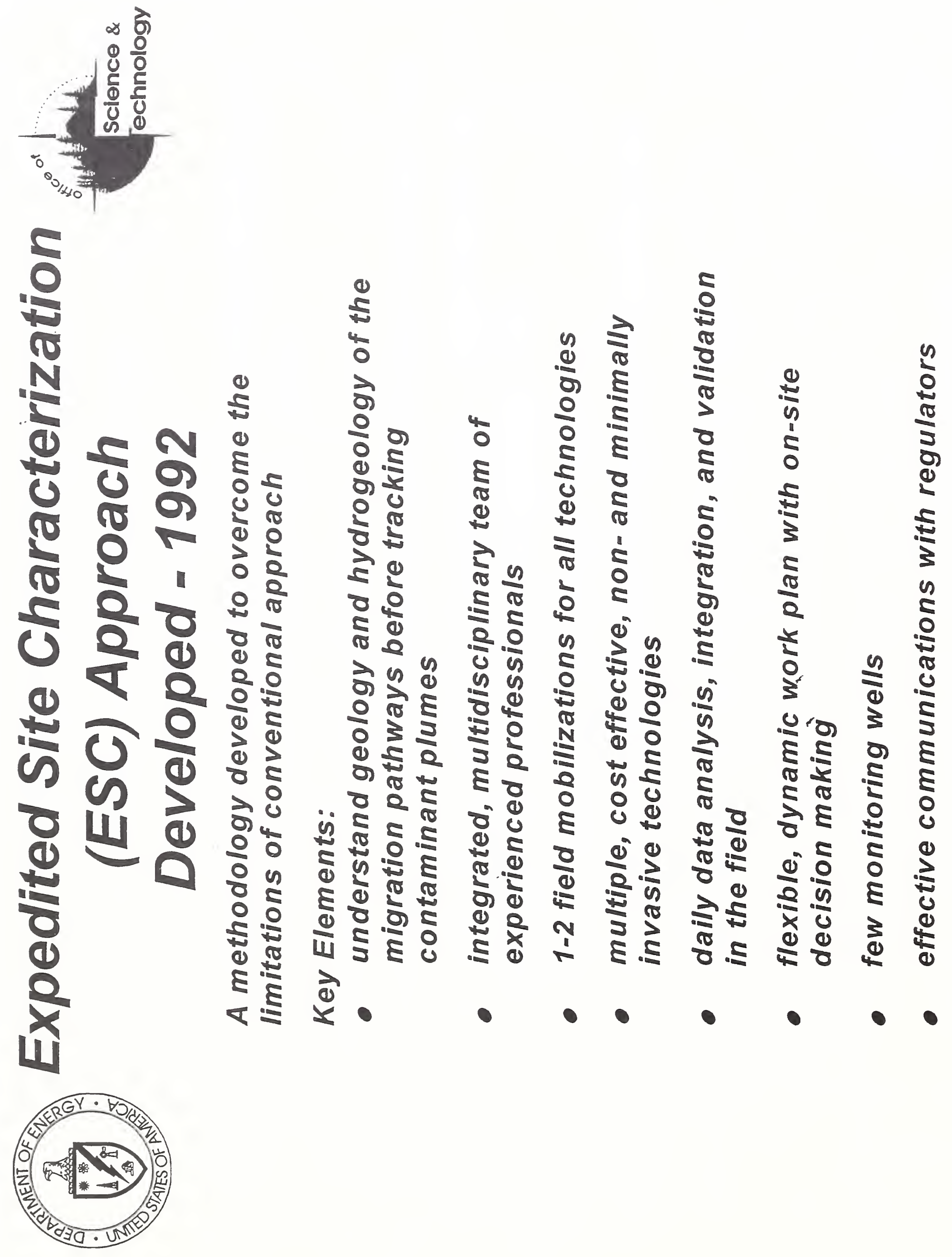


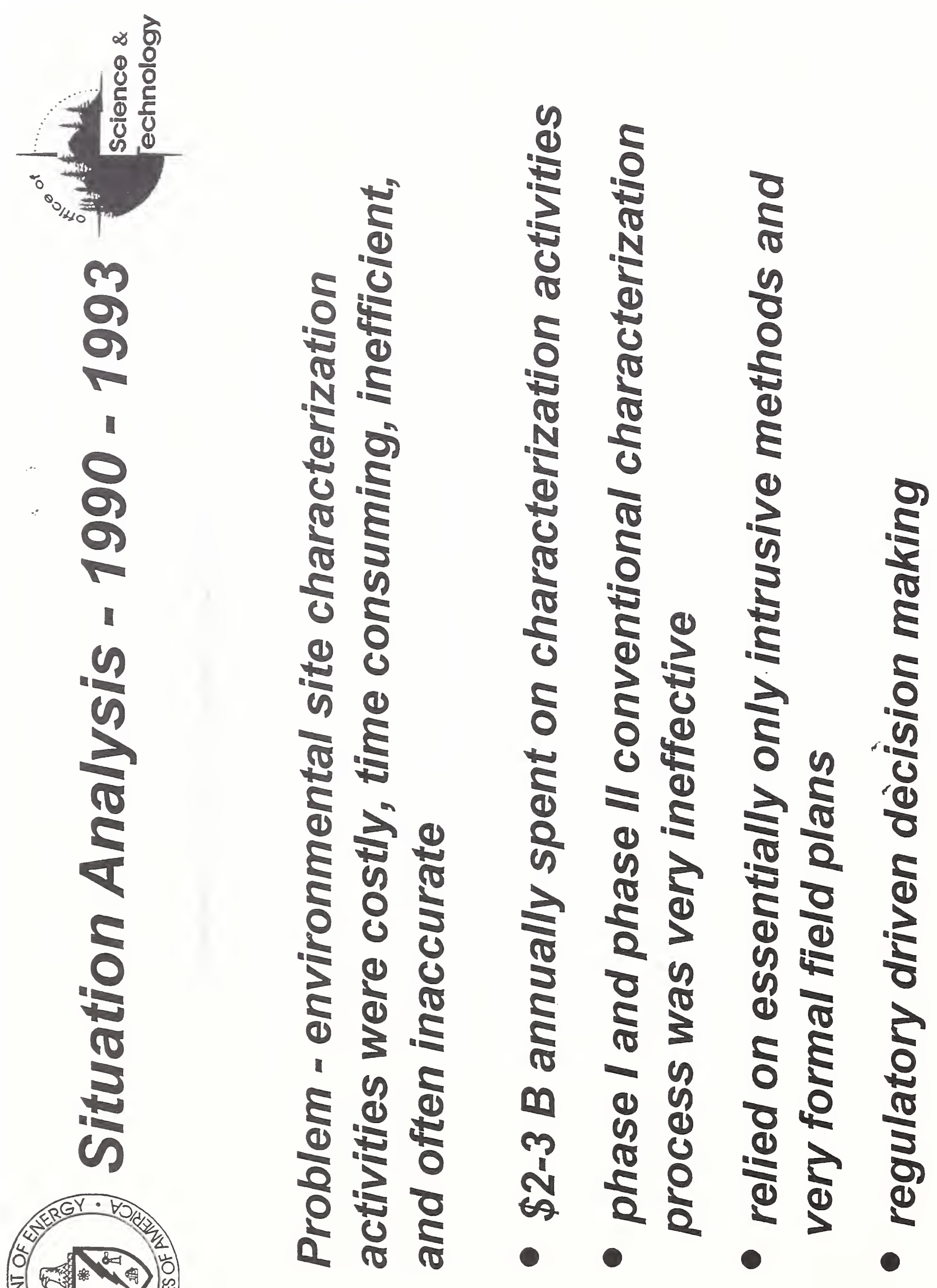




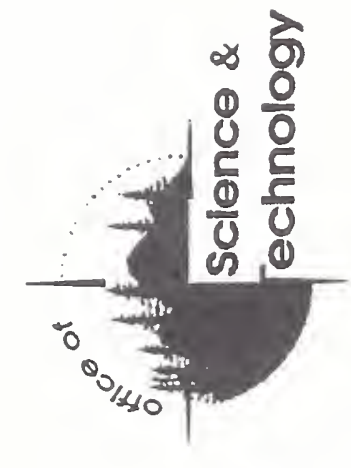

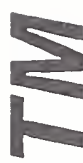

c

5

Q 0 जा

a

e 100

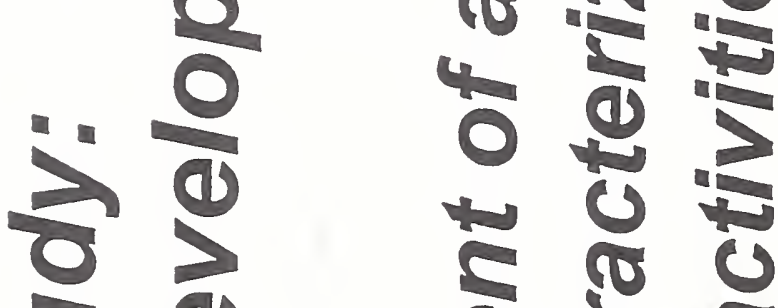

$\infty a$

$\rightarrow \infty$

13

(a) 50

(a) 2

(2) 90

100

(1)

山

O क

0

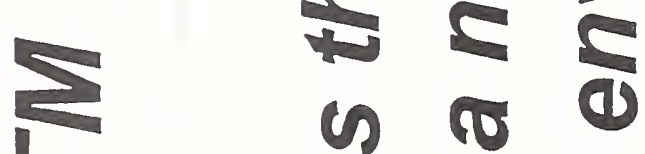

a) 0

(1) 15

(a) 5

(1) 0

(1) 0

s

$\nabla$

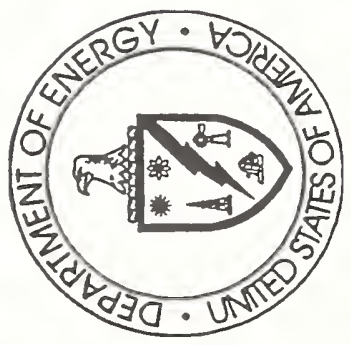

1024

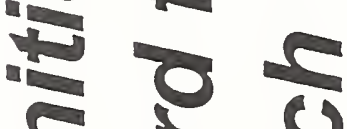

Q. $2+2 \geqslant$

Q. a. 0

(1) $0 \geqslant 10$

$\geqslant 010$

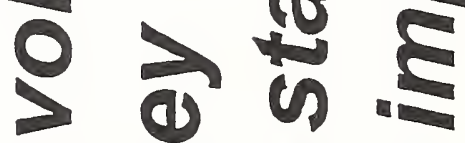

E 5 a a

0 का से

100010

100

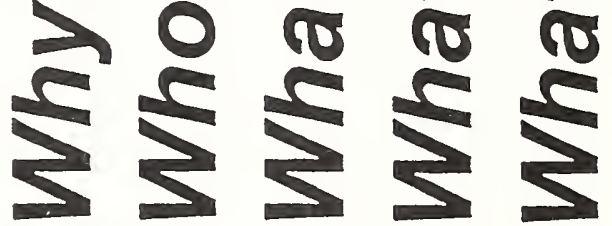

4 00

( 10

$45 \frac{0}{40}$ 
Section 5

\section{Procurement Standards Panel}



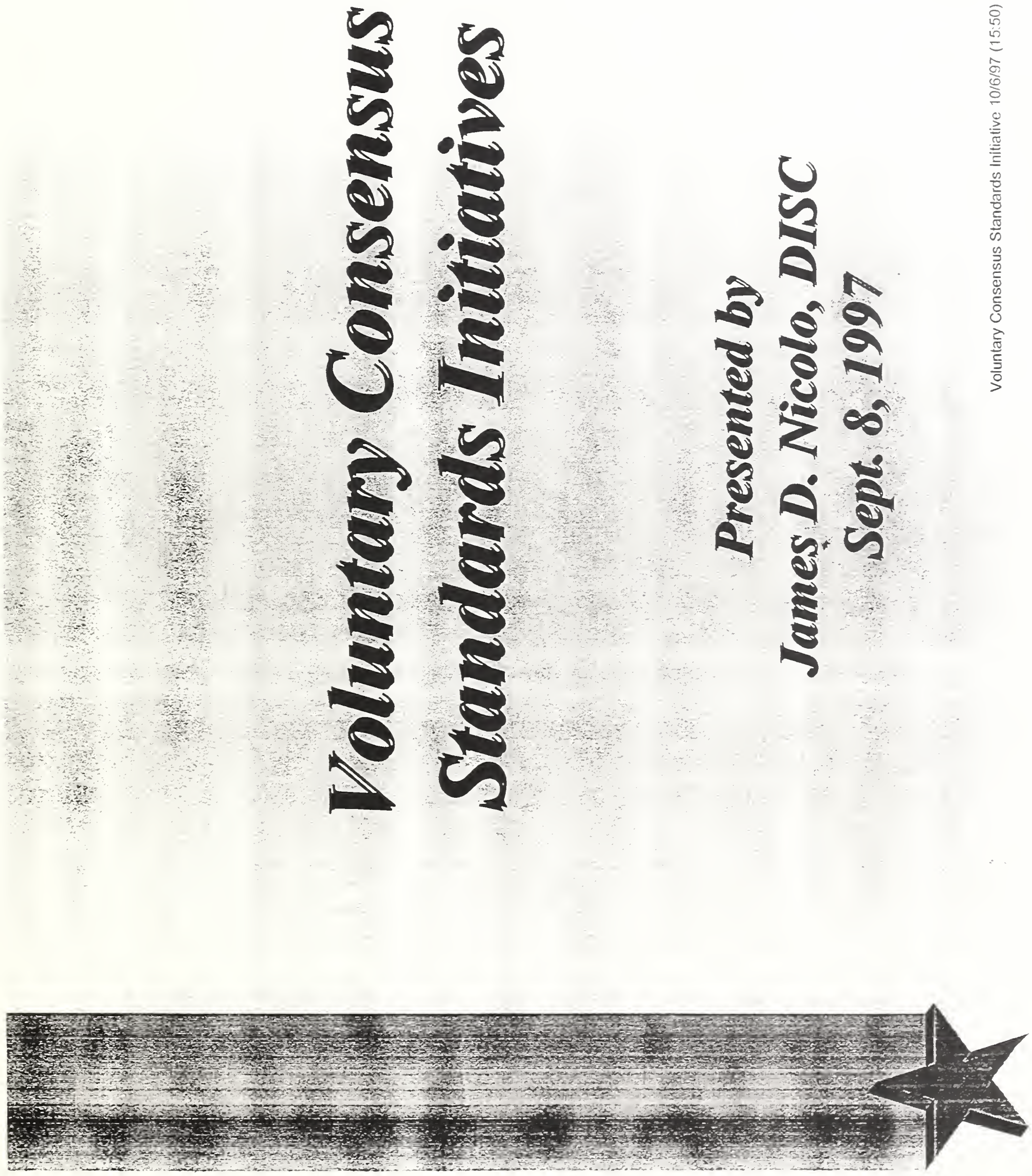


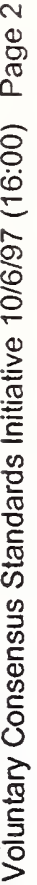
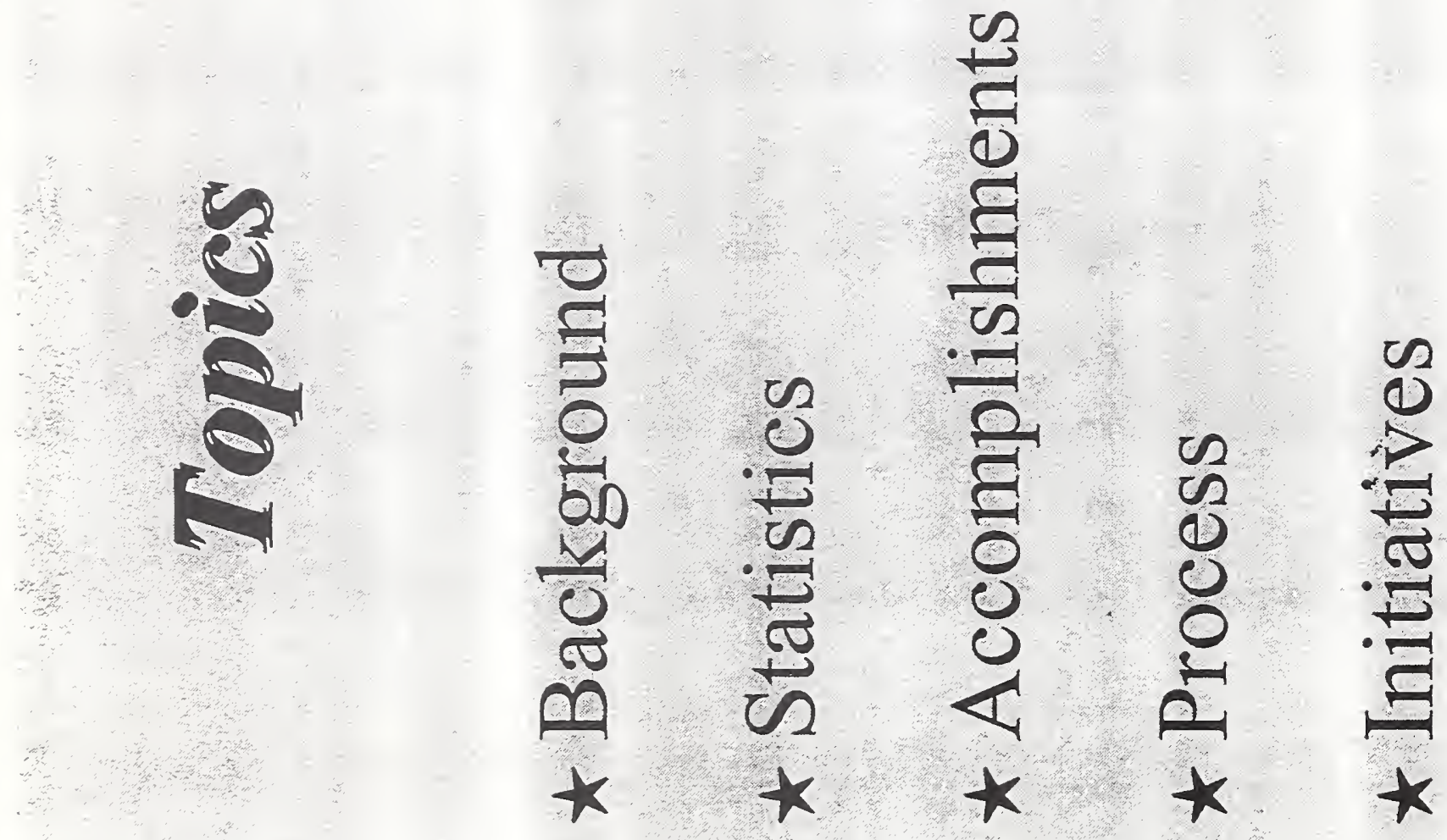

$\stackrel{\sqrt[n]{0}}{0}$

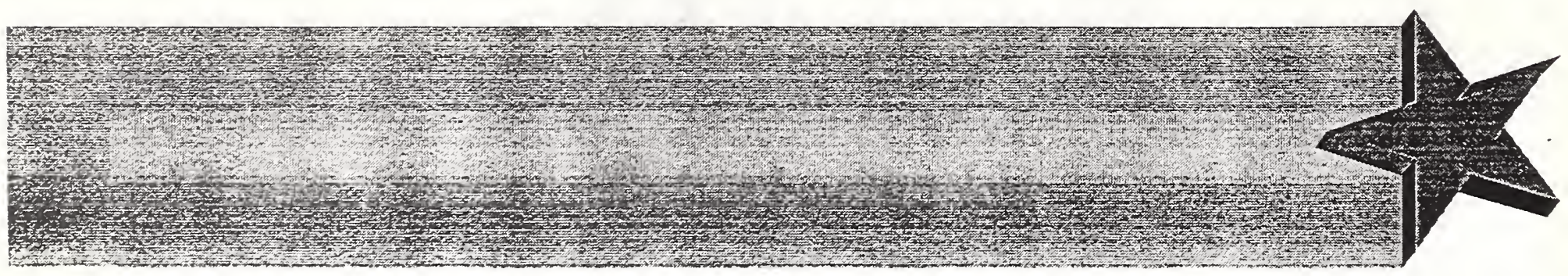



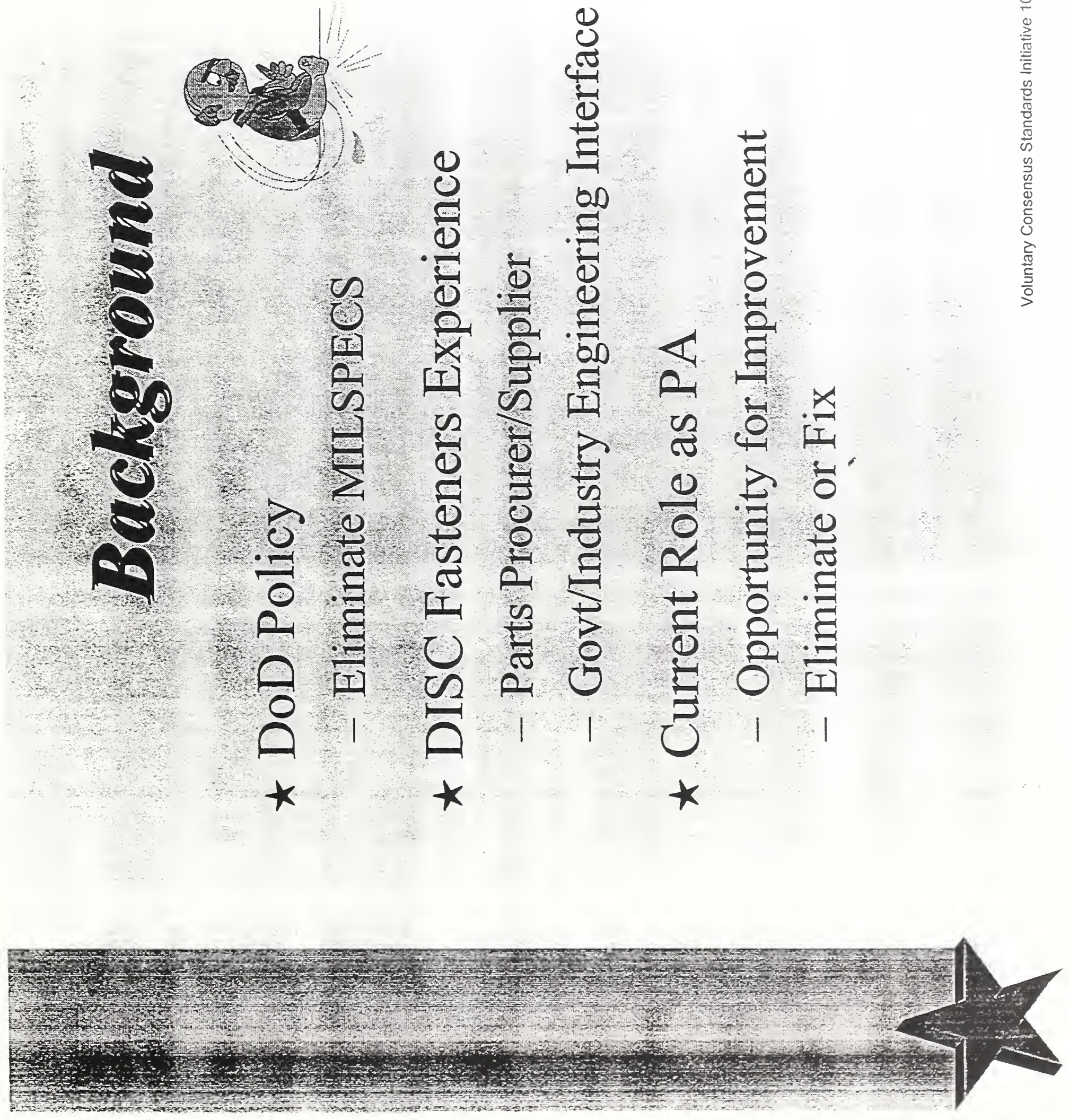

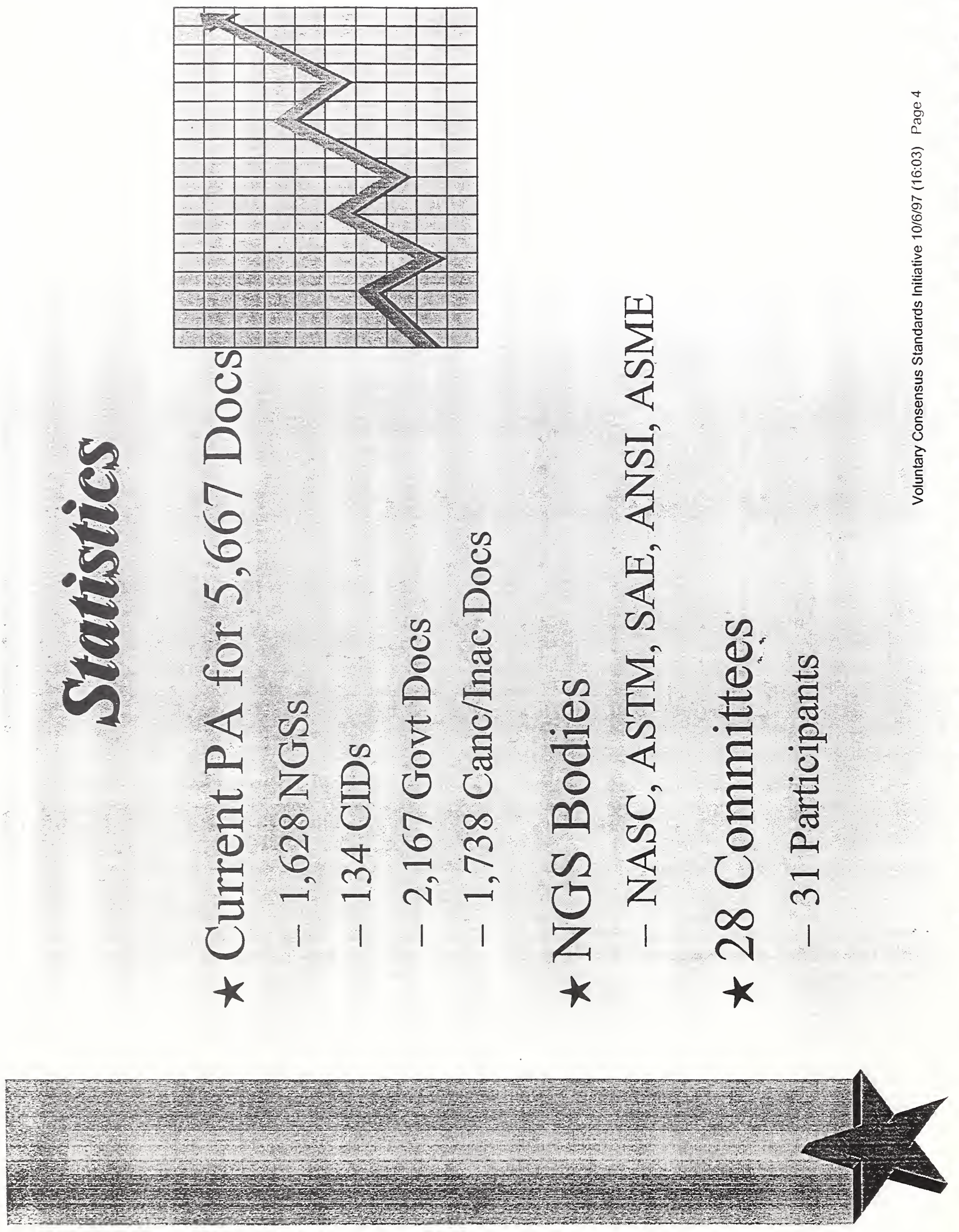


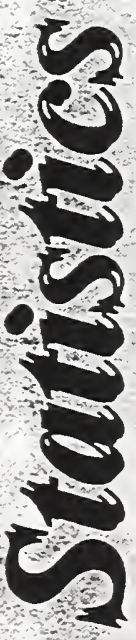

2

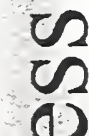

(1)

E.

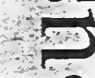

$\begin{array}{ll}0 & 0 \\ 0 & 0 \\ 0 & 0\end{array}$

थ $\frac{\theta}{\sigma}$

(1) $\sum$

(c)

is

ब०

⿶凵

02

已

$\begin{array}{ll}\sum_{\infty}^{\infty} & \frac{\pi}{i} \\ \sum_{i}^{\infty} & 0 \\ z_{1} & 0\end{array}$

(1) 00

7

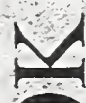

1

$\frac{1}{6}$

0

$\sum_{1}$

$\sum$

U

88

尺

N 6

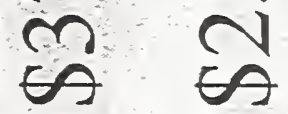

$\theta$

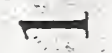

$\star$

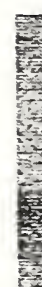




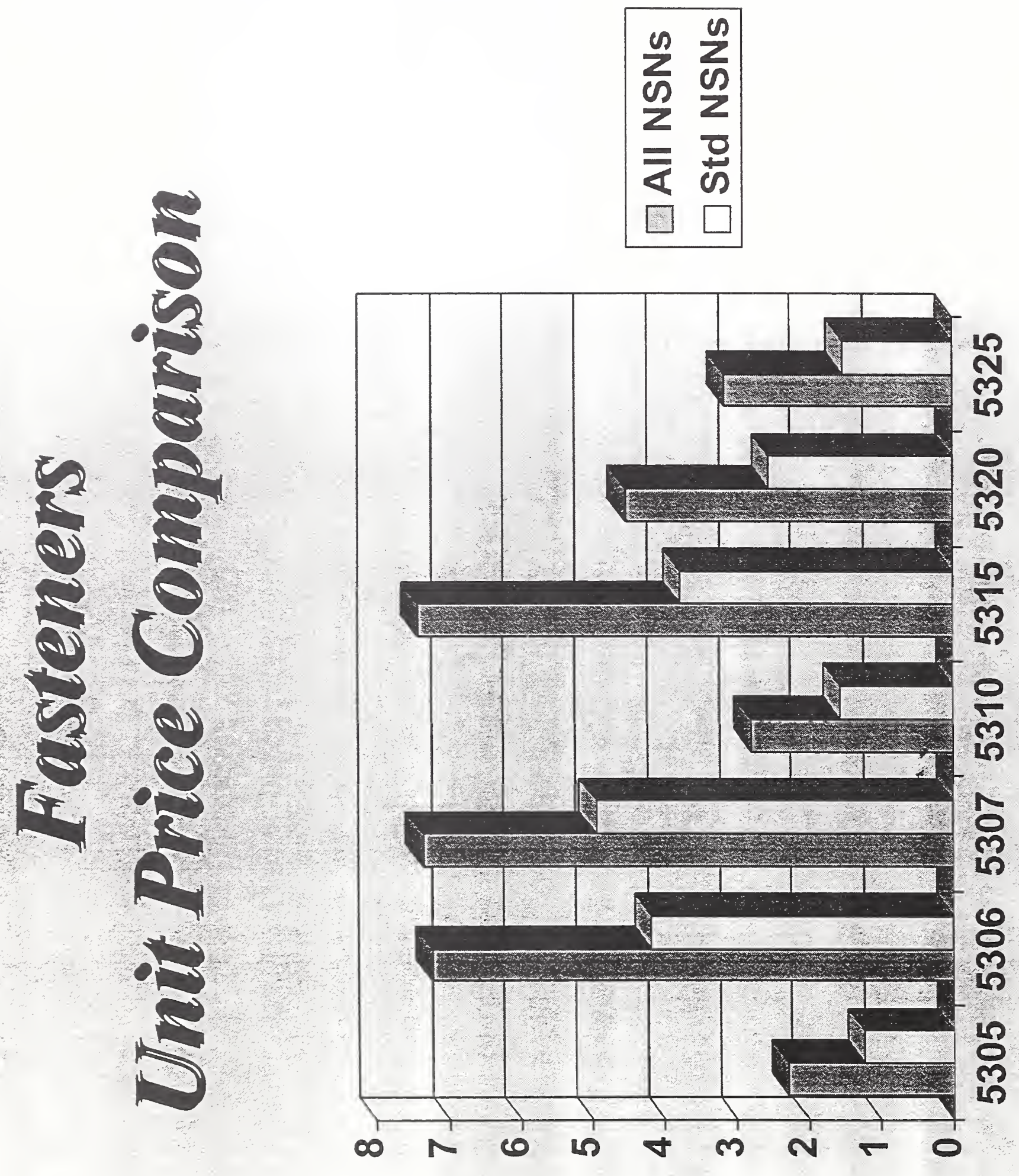




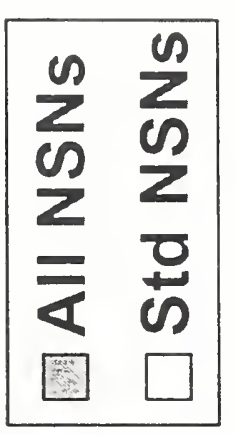
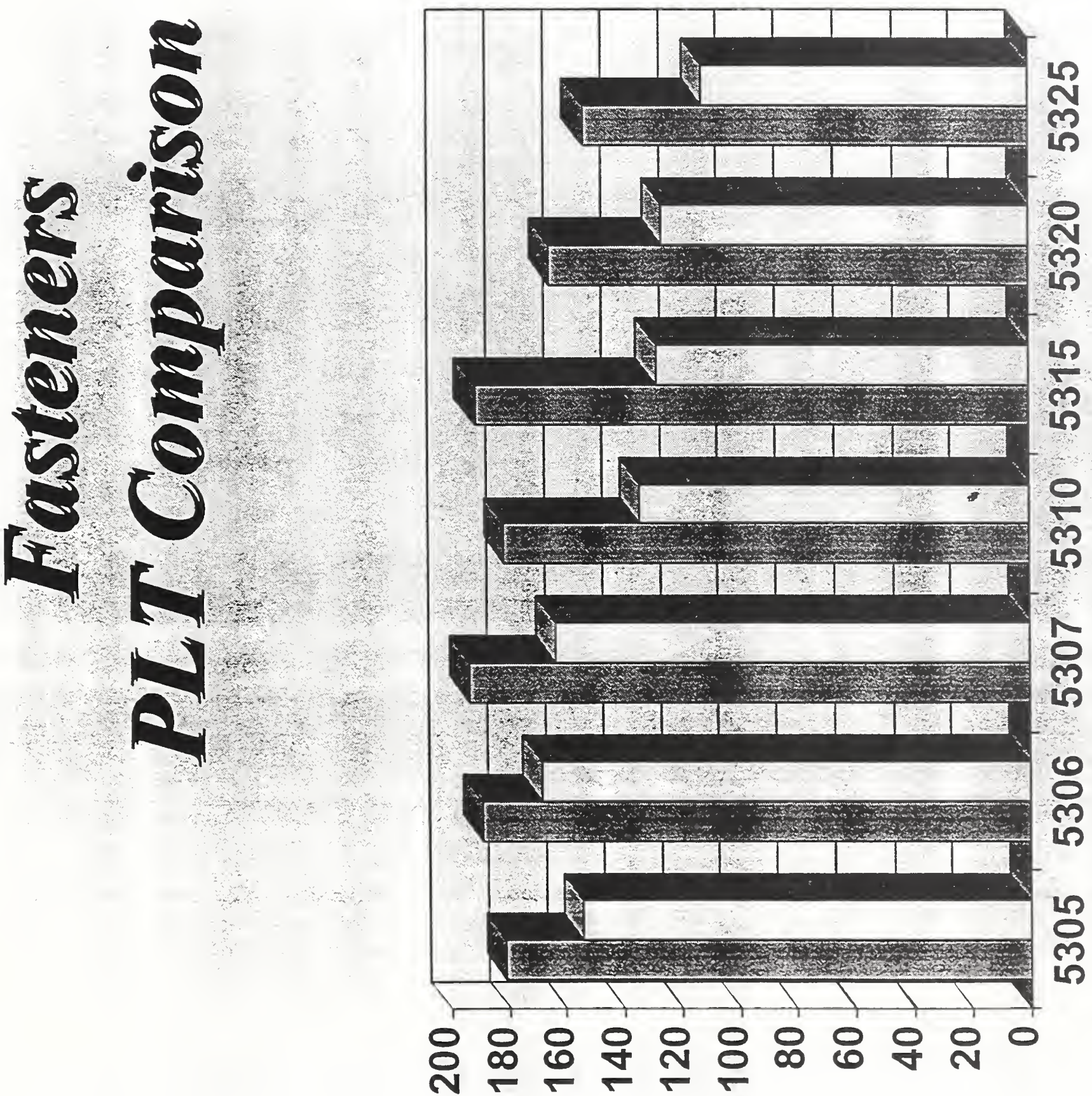


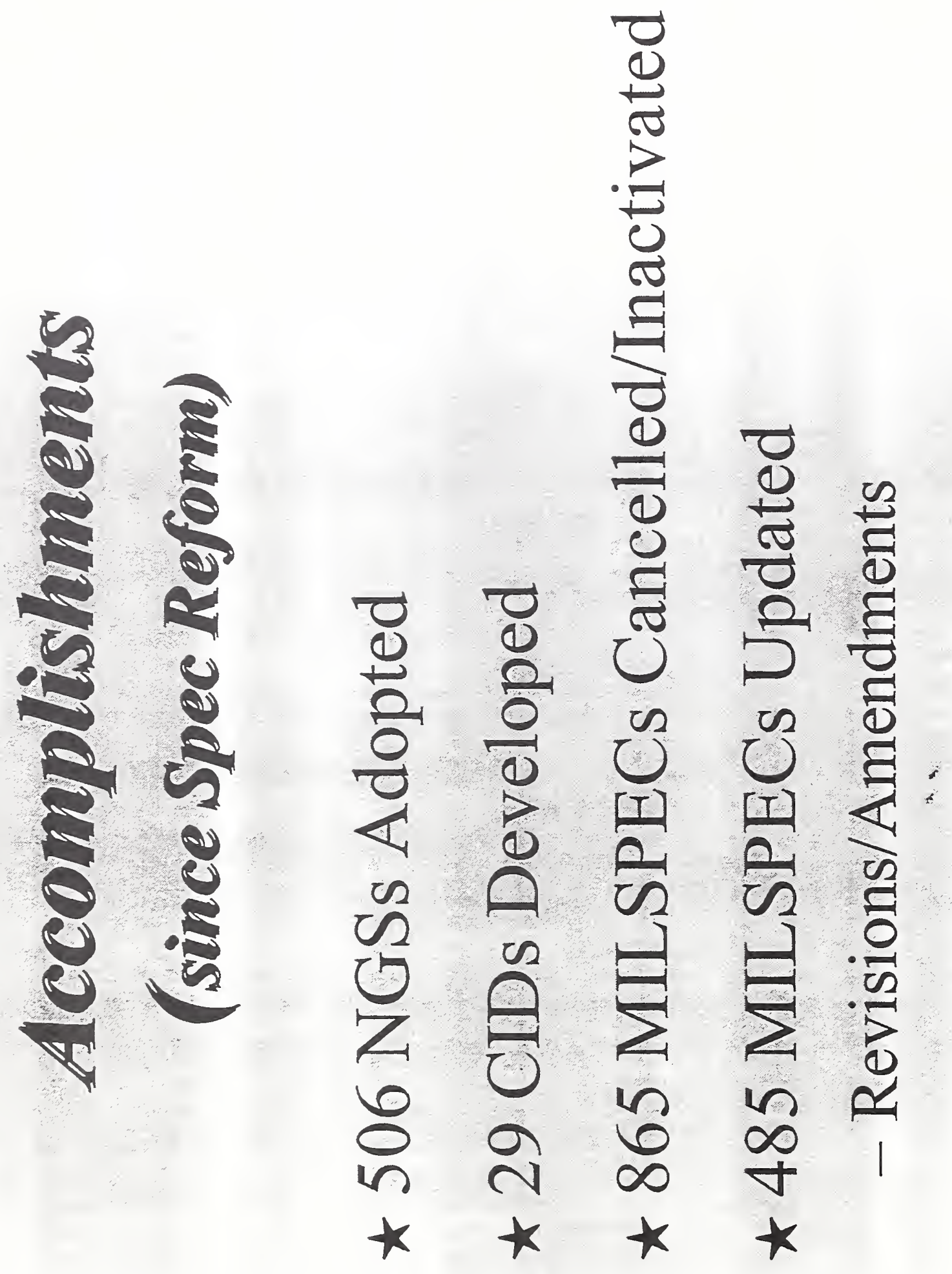

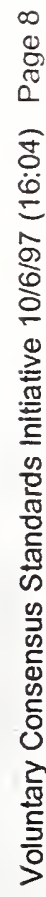

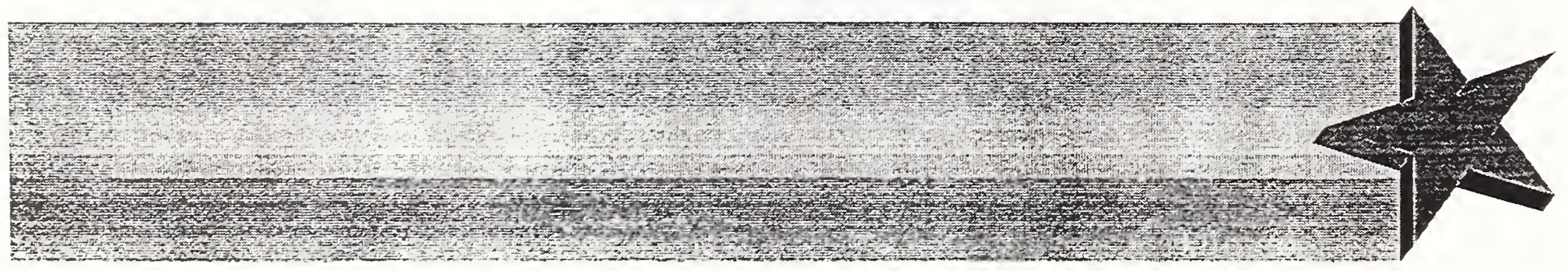



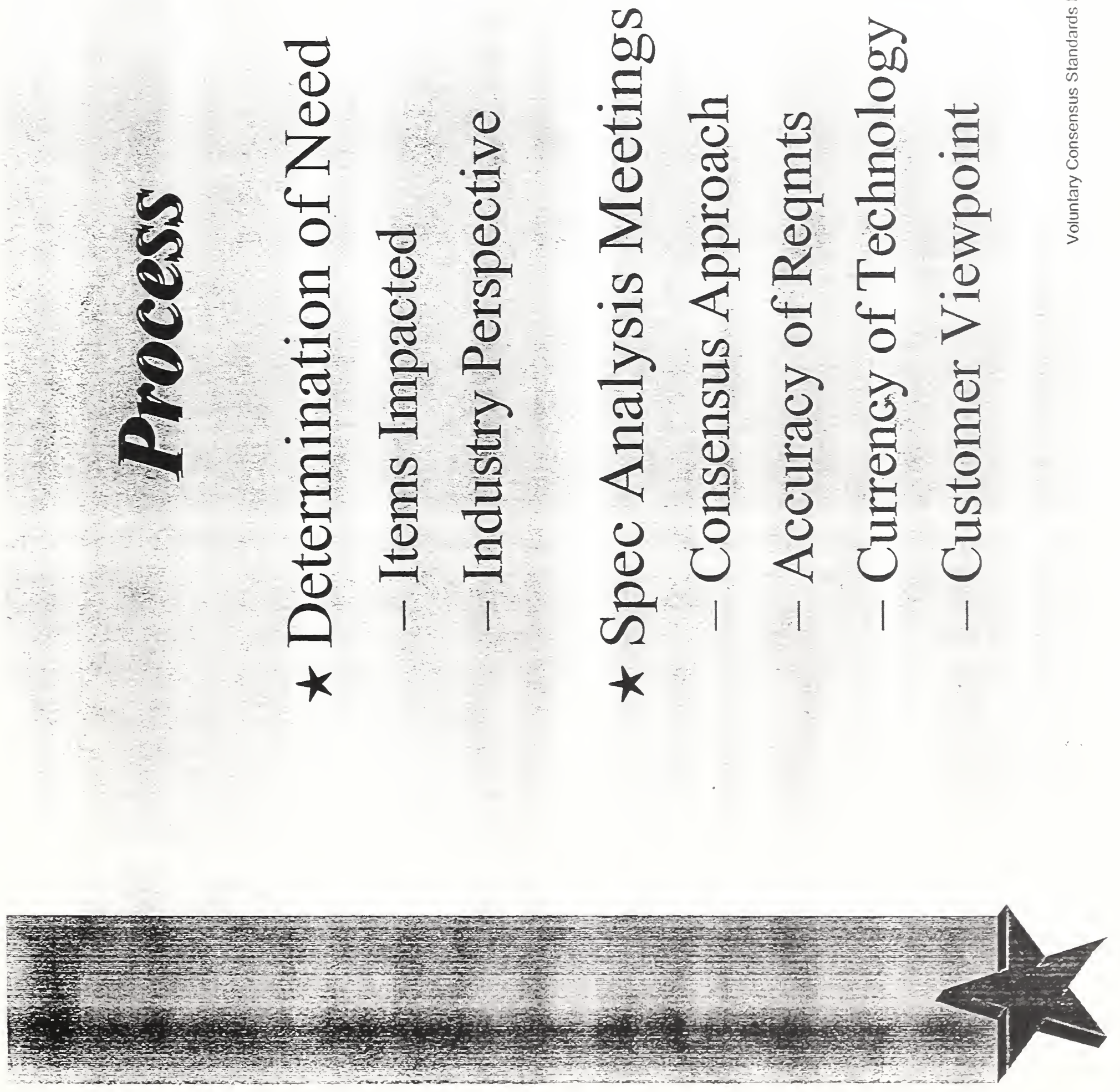

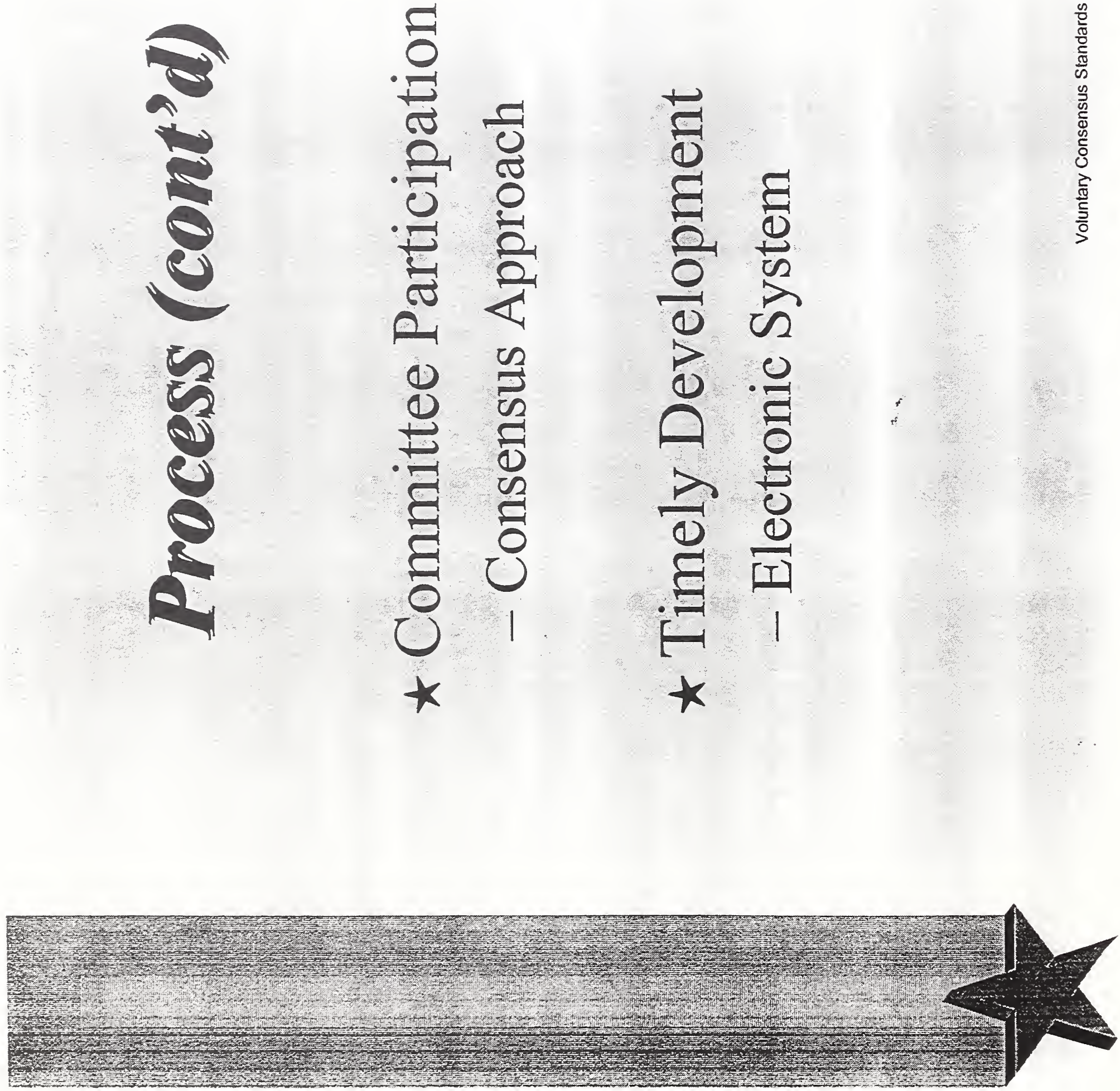

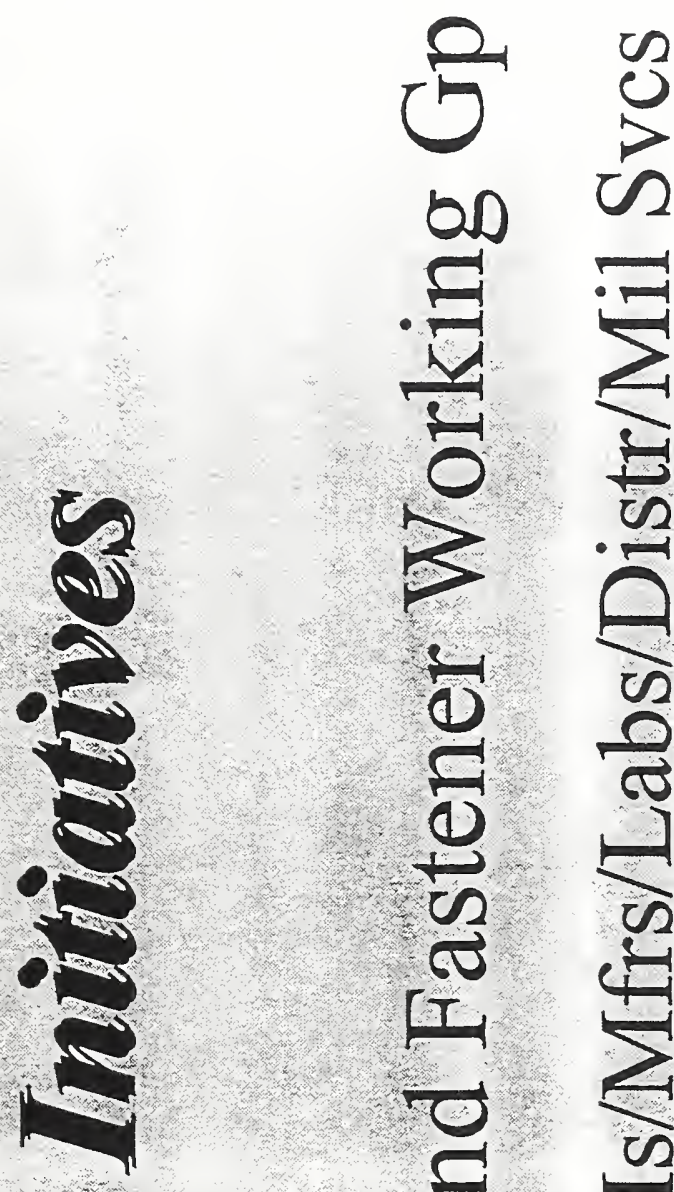

op

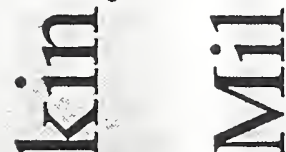

$\overline{0}$

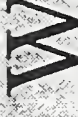

(1)

(1)

t

त

II

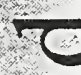

트

$\frac{1}{2}$

OD

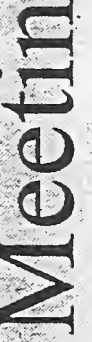

$\frac{2}{2}$

핑

8
0

k

* 

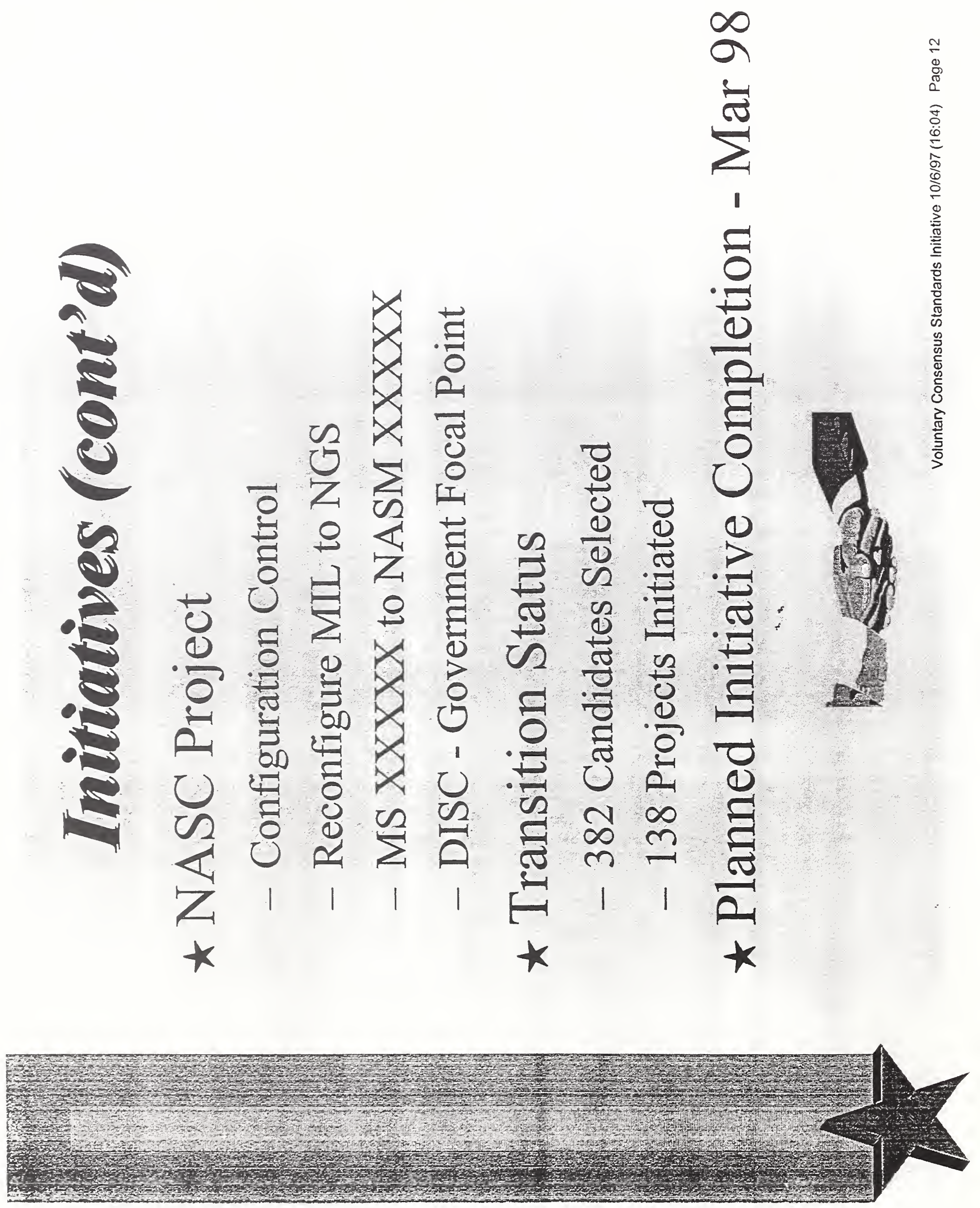


\section{CASE STUDY}

\section{TRANSITION OF MILITARY STANDARDS AND SPECIFICATIONS TO NON-GOVERNMENT STANDARDS BODIES}

Specifications and Standards Reform is a DoD mandated initiative under the umbrella of Acquisition Reform. In the past, Military Service Document Preparing Activities (PA's) were responsible for the development, maintenance, and update of specifications and standards that govern the products that the DoD procures. These specifications and standards are important to the Defense Industrial Supply Center's mission to supply hardware to the military services and various federal agencies. They describe and control the technical characteristics of the products that we buy for our customers. Therefore, they provide the essential ingredients to ensure our procurement and supply of quality, conforming products. Industry too, has a vested interest in these documents. These standards and specifications describe hardware that is not military or government unique, but has widespread use and acceptance in various sectors of industry. In fact, in the aerospace community, both Original Equipment Manufacturers (OEM's) and hardware manufacturers have, over the years, been an integral part of the standards development process. As a consequence of the types of standards we are dealing with, as well as the active participation of various facets of the hardware manufacturing and using community, many hundreds of military documents are de facto national, and international standards.

The formidable task of maintaining specifications and standards is balanced against a DoD policy which advocates the elimination, where possible, of military specifications and standards. That policy encourages the development of commercial standards, the adoption and use of Non-Government Standards (NGS's), the replacement of current military documents with ones that are performance-based, or the outright cancellation or inactivation of the military version. To adhere to DoD policy, on the one hand, and to make certain, on the other, that our commodities continue to be adequately and accurately covered by standardization documents, we have developed a plan for the transition of military specifications and standards to NGS's. In pursuing this effort, we are preserving the Part Identification Numbers associated with the military documents that, for both government and industry, are so vital to the logistics support of weapons systems and equipment. Retaining existing part numbers will preserve configuration control on hundreds of thousands of technical drawings, documents, and engineering data. We continue to work closely with the appropriate NGS organizations, the government and industry communities involved in systems design, parts manufacturing and supply, maintenance, use, and testing fields to ensure a viable approach to the conversion of military documents. As a result, we have embarked on a comprehensive program effort with the Aerospace Industries Association, through it's National Aerospace Standards Committee (NASC), and the Society of Automotive Engineers (SAE) E-25 committee on General Standards for Aerospace Propulsion Systems, to transition needed military documents to counterpart Non-Government Standards. 




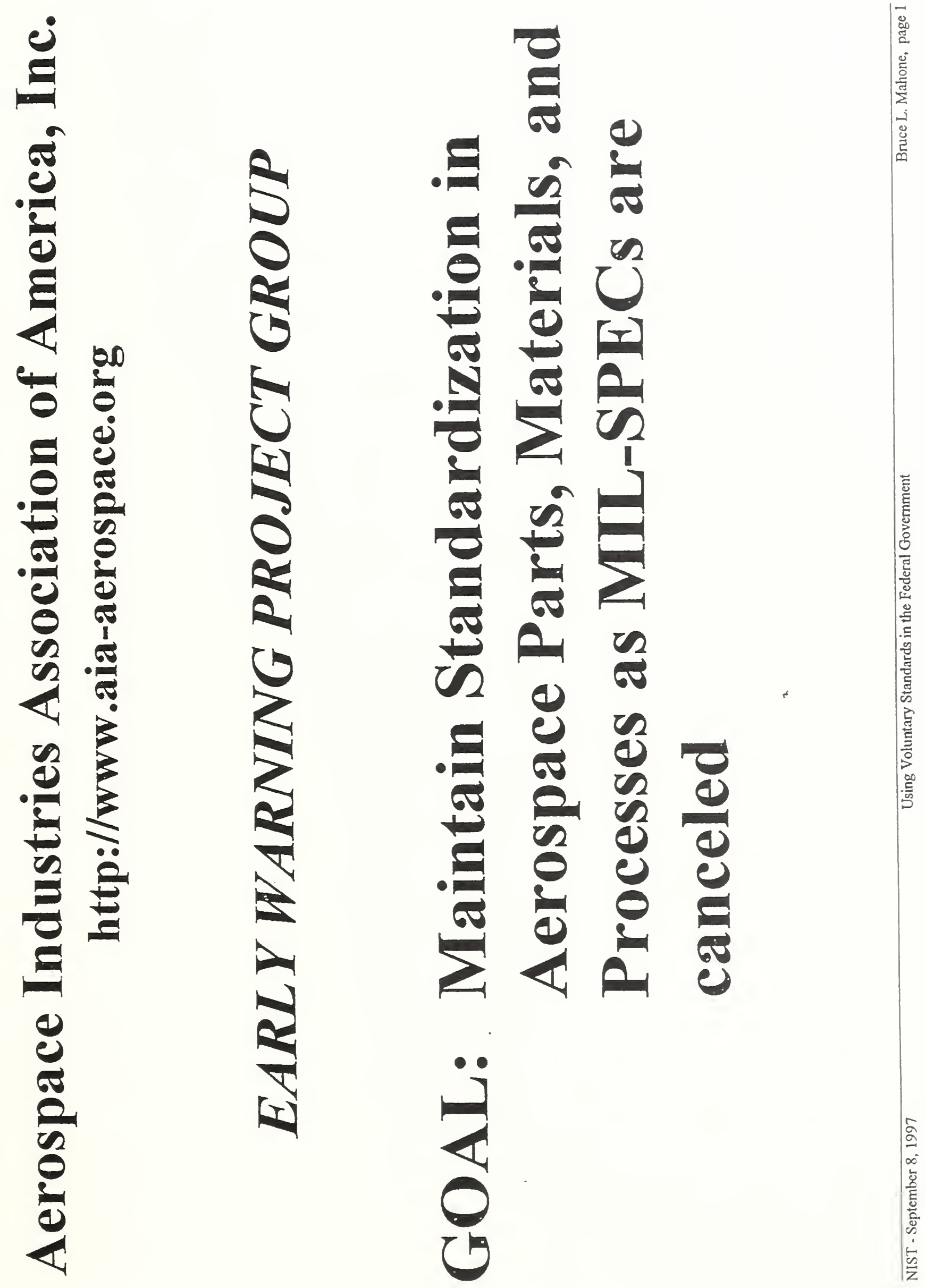



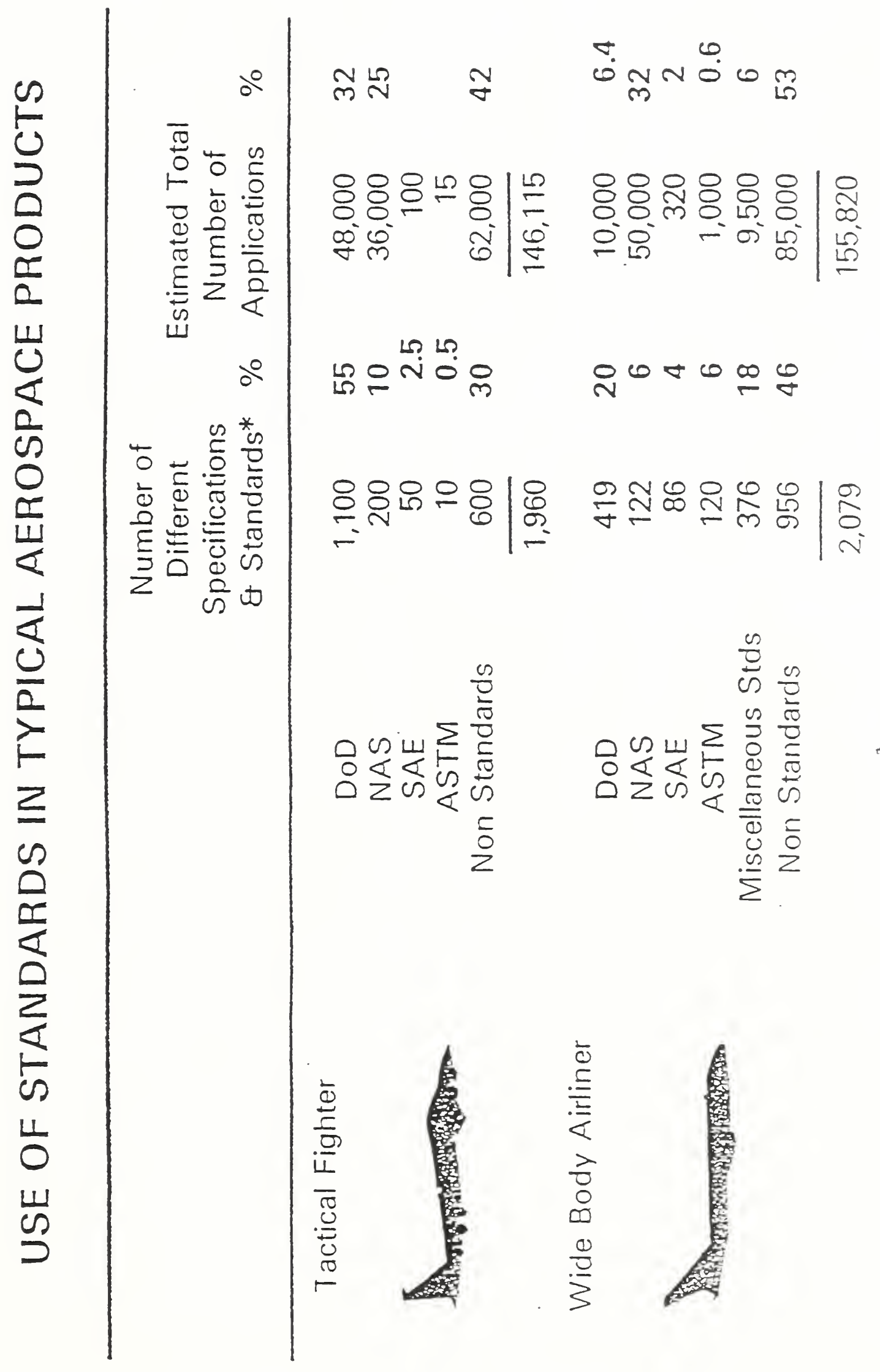





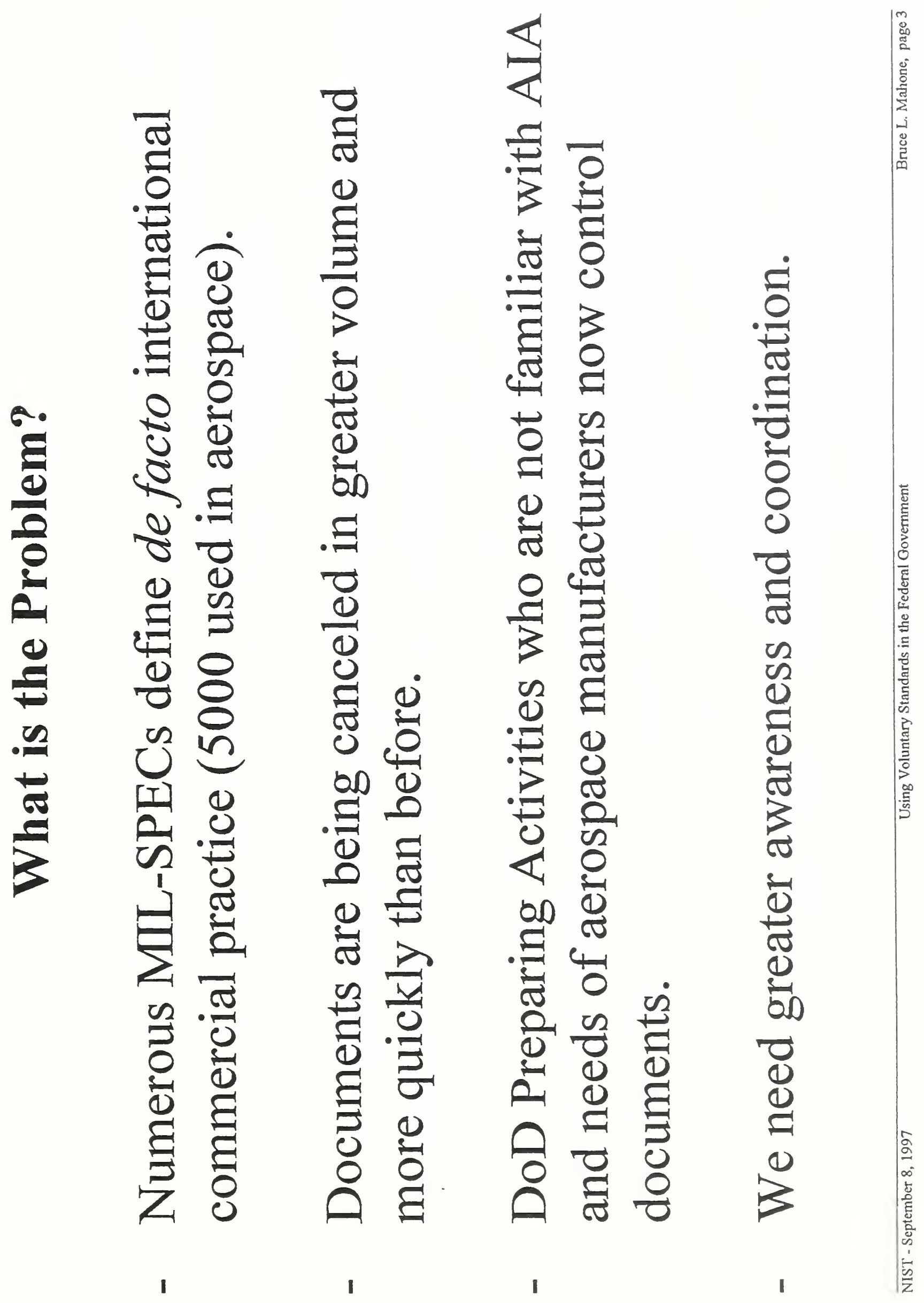





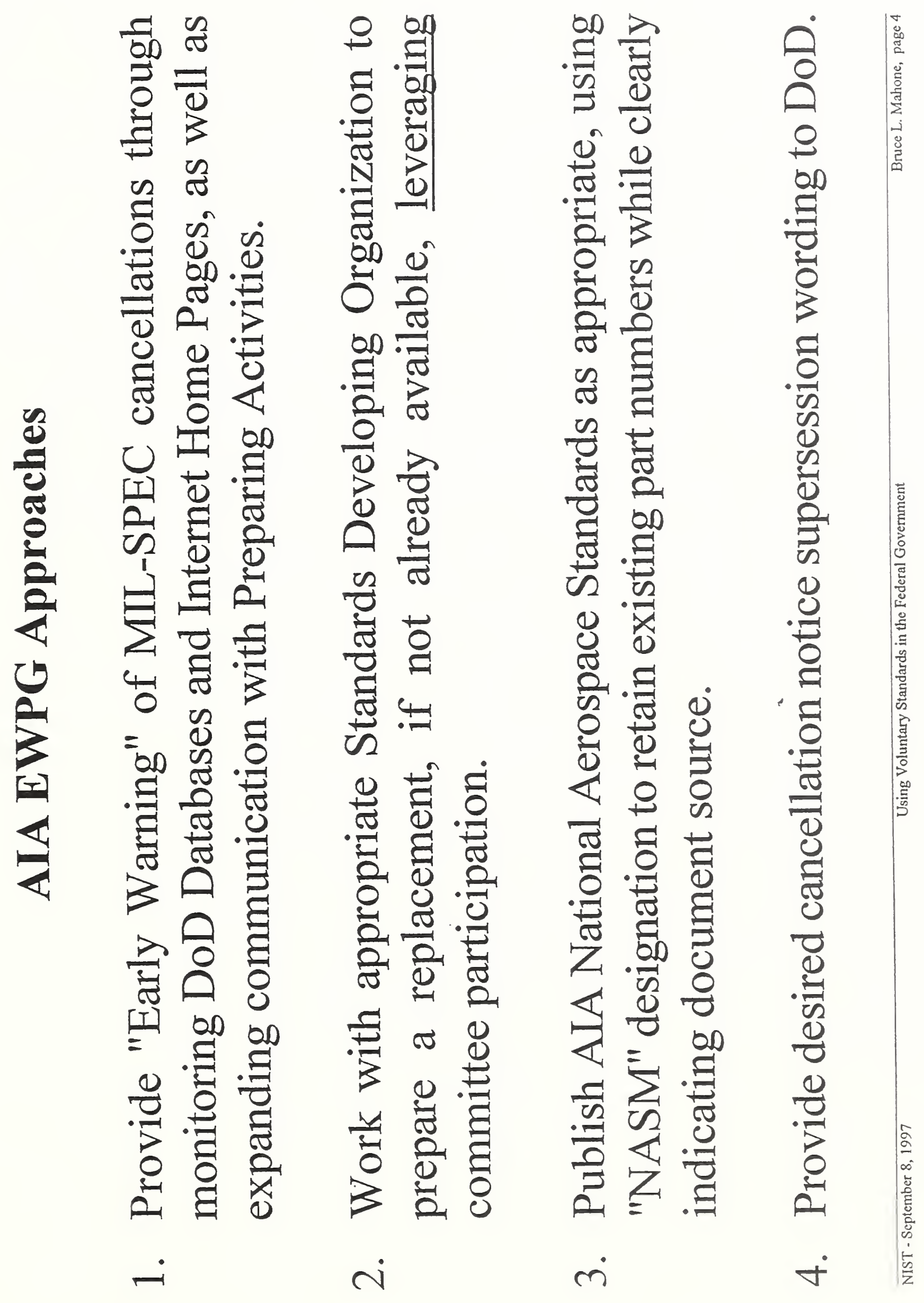






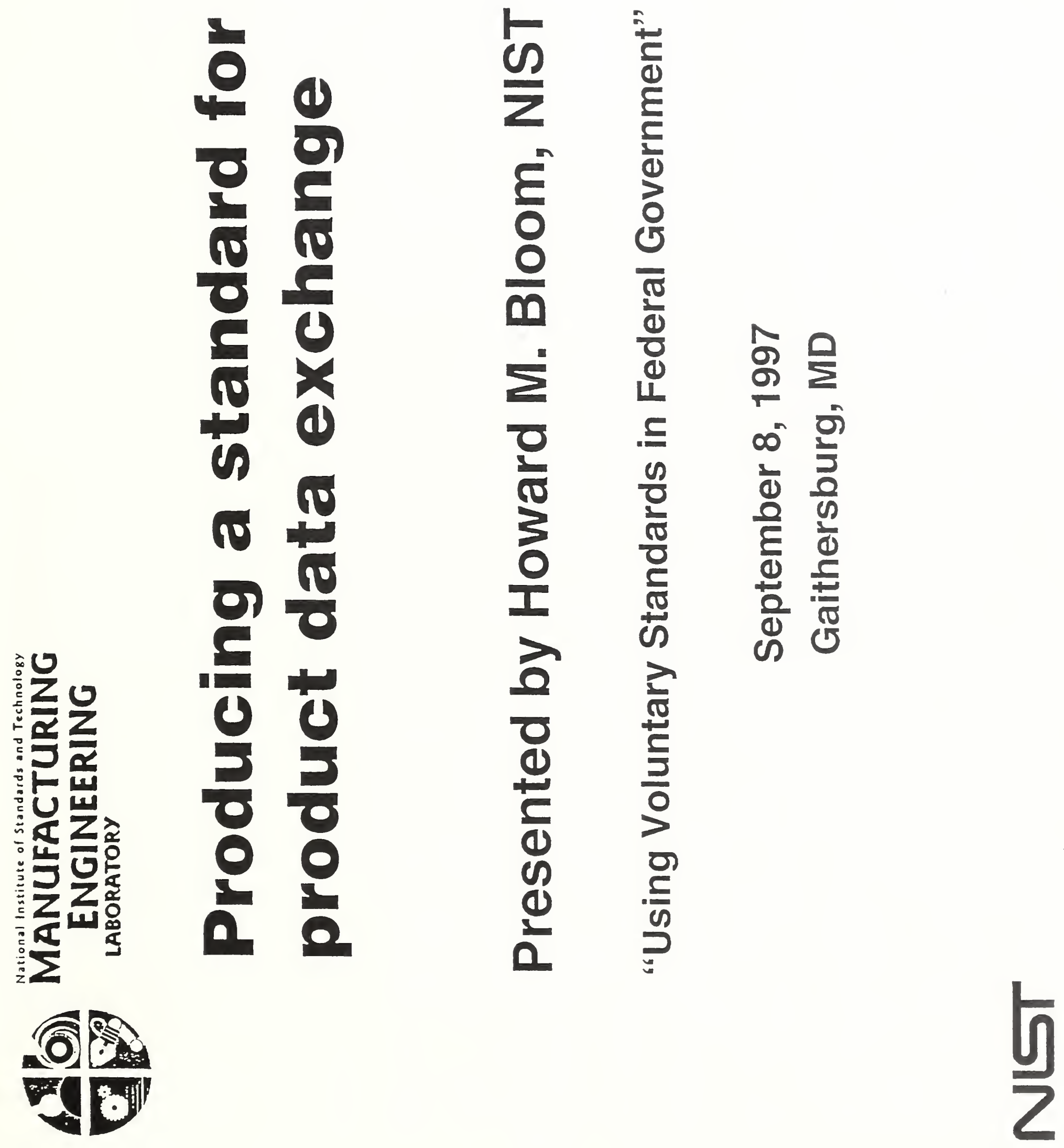


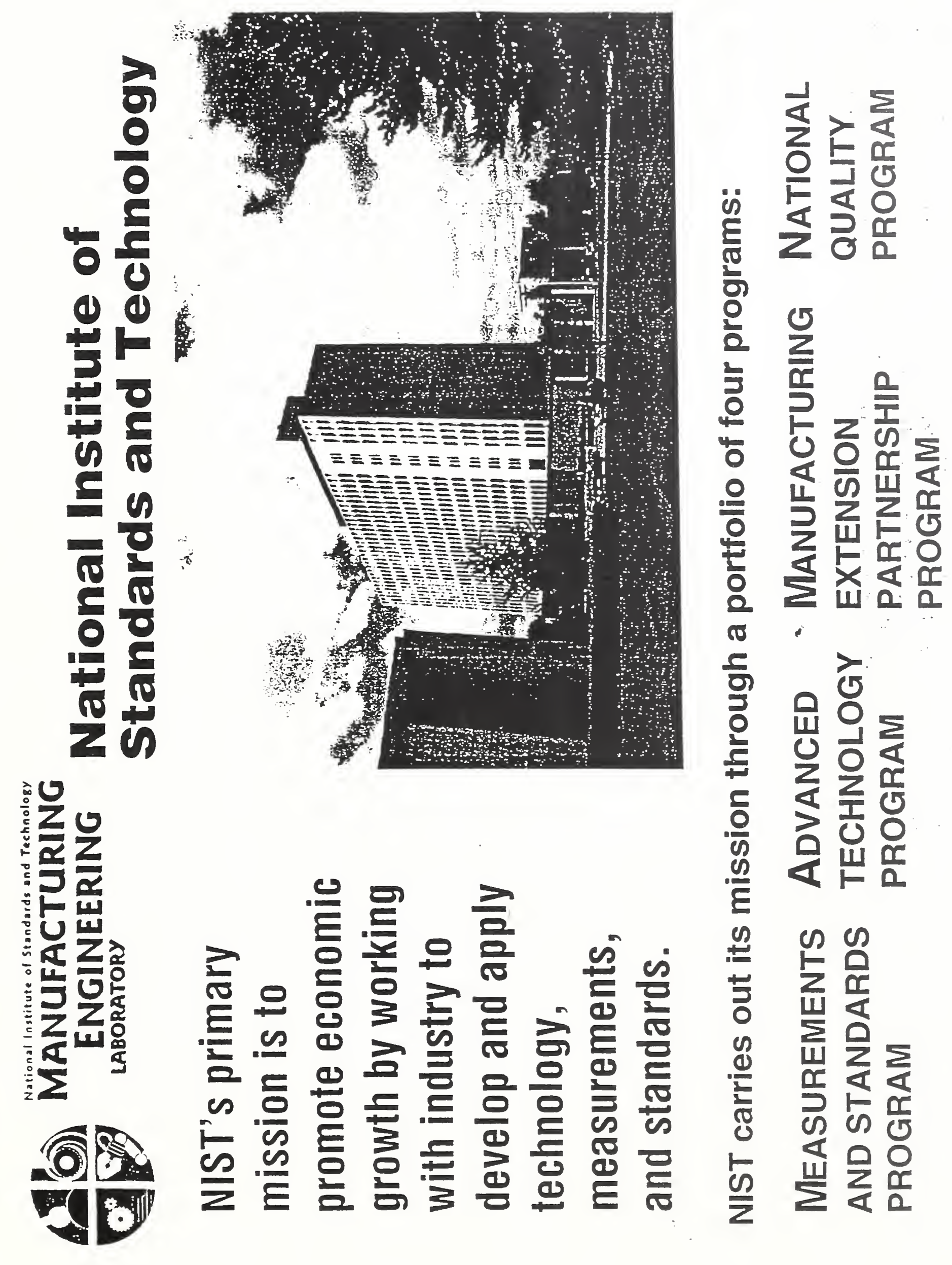




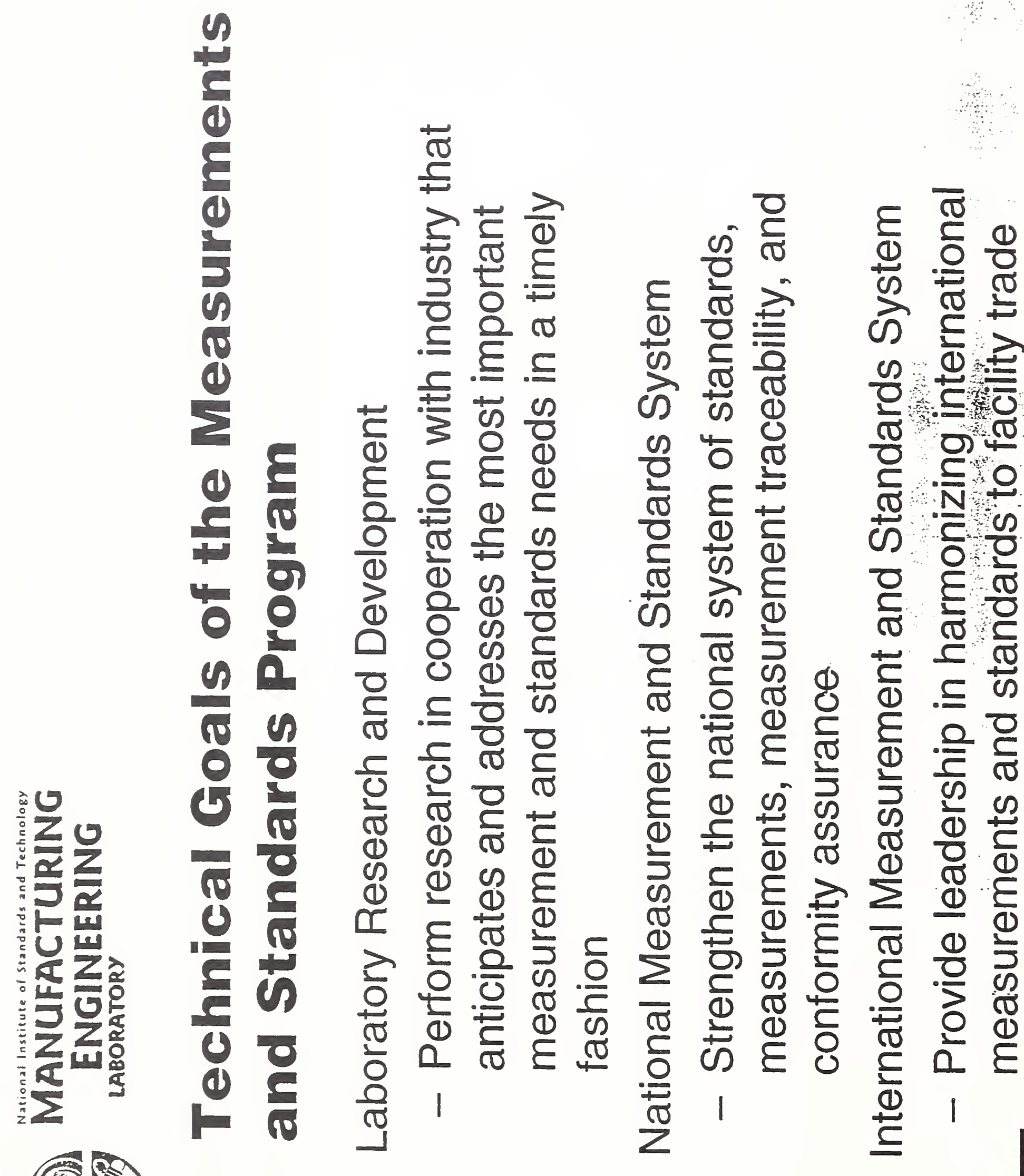




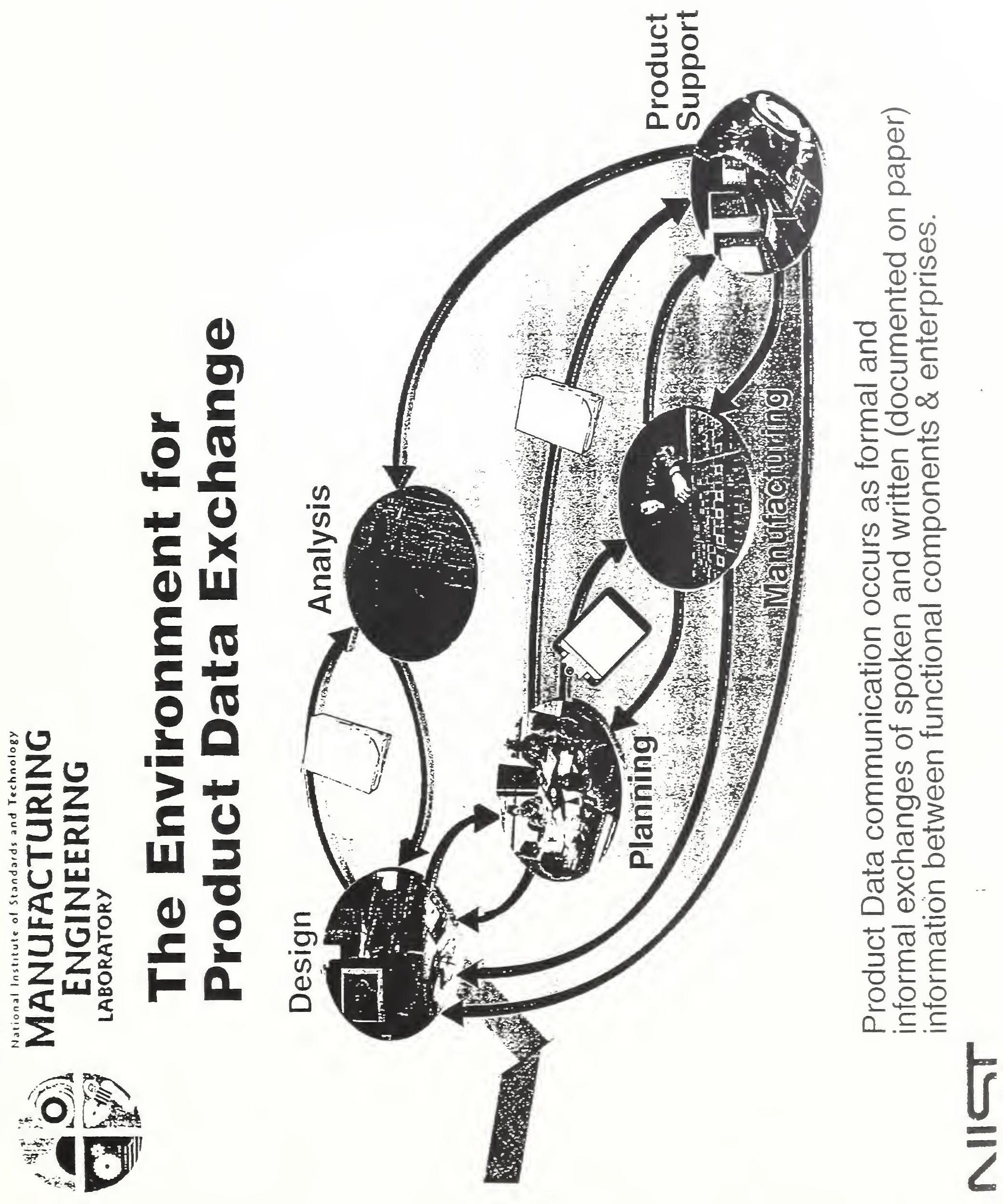



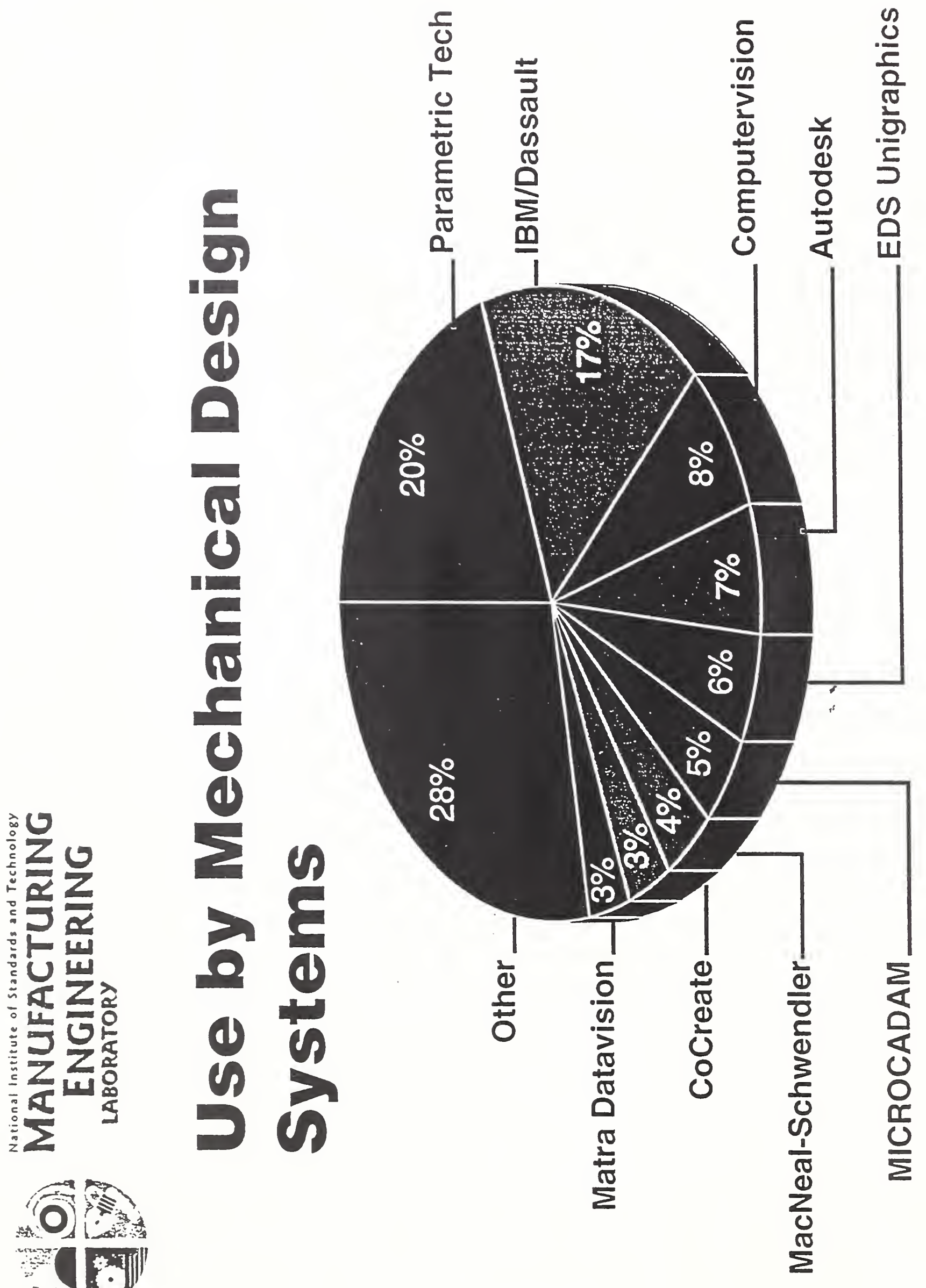

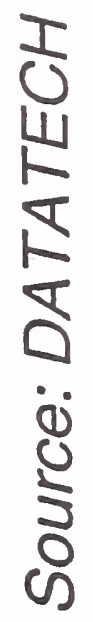

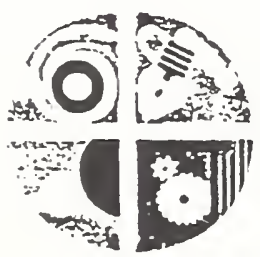




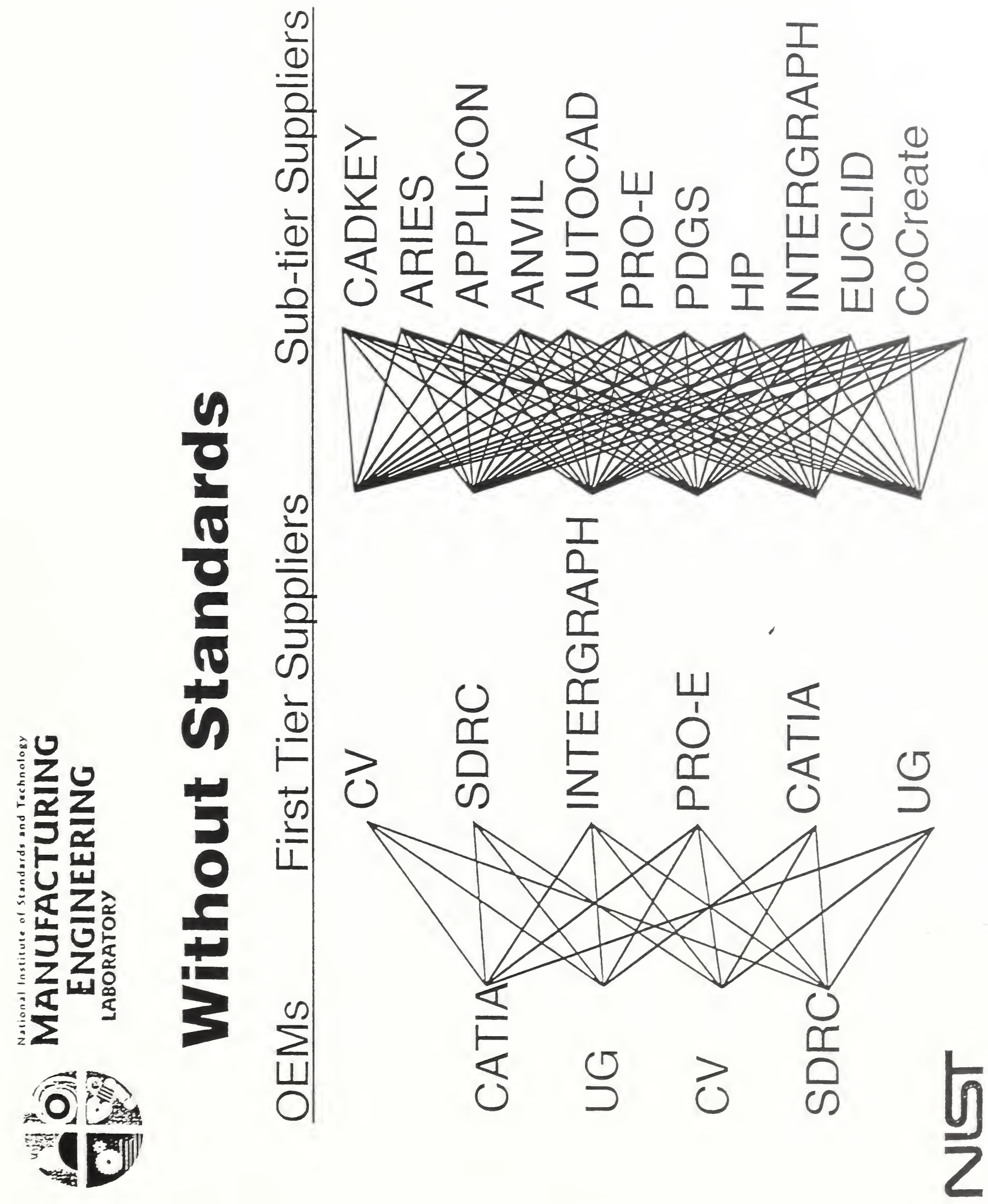




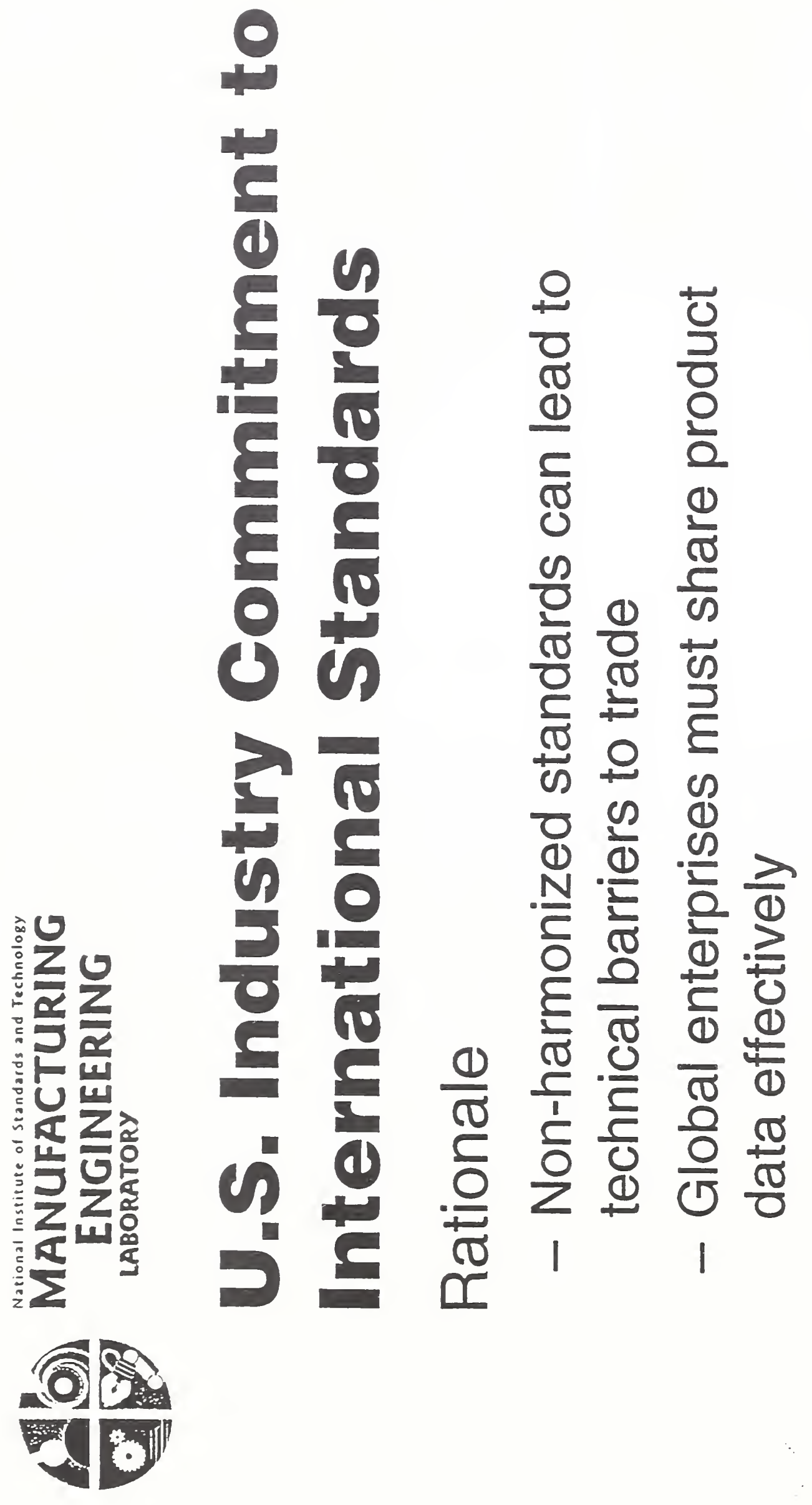



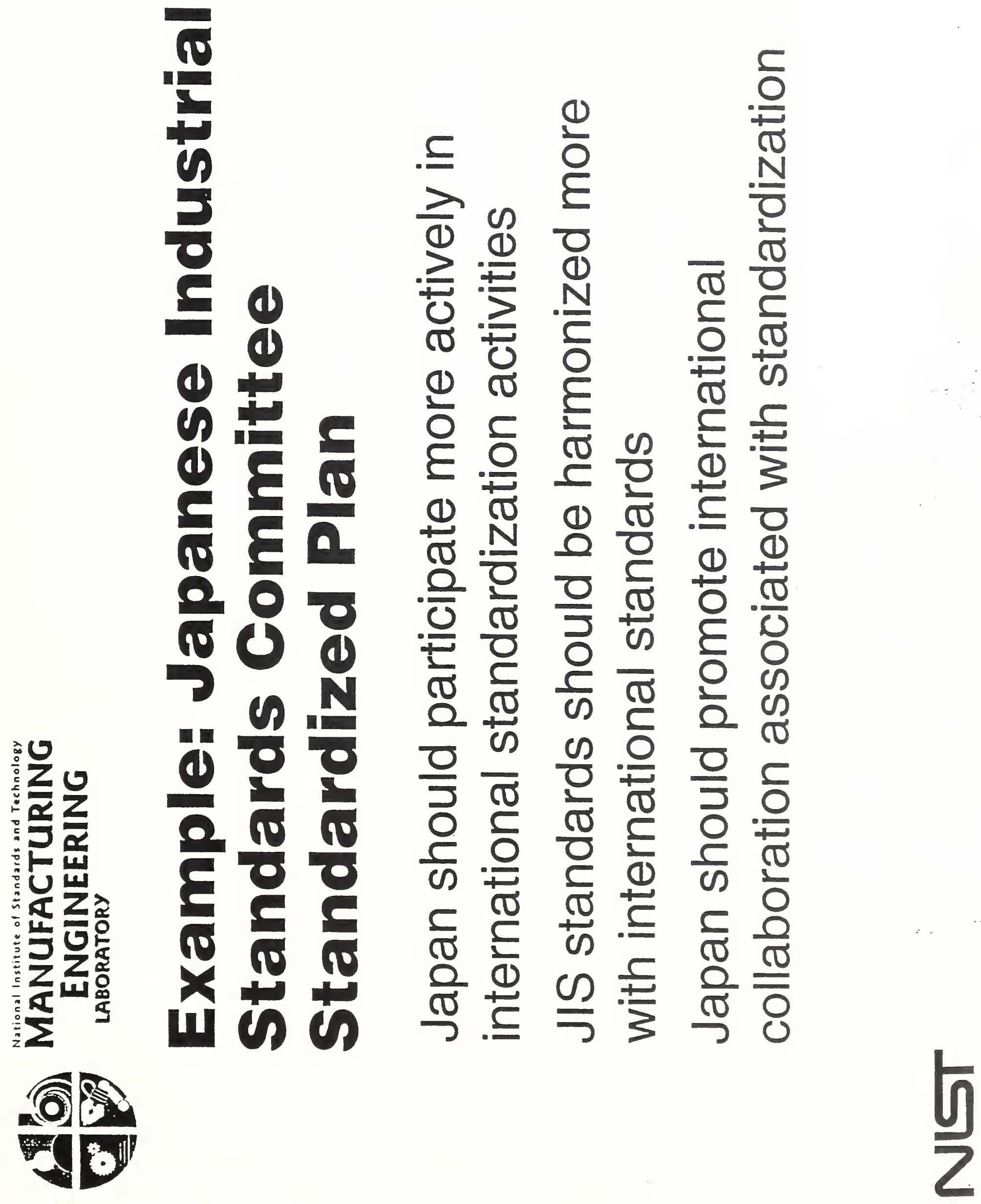


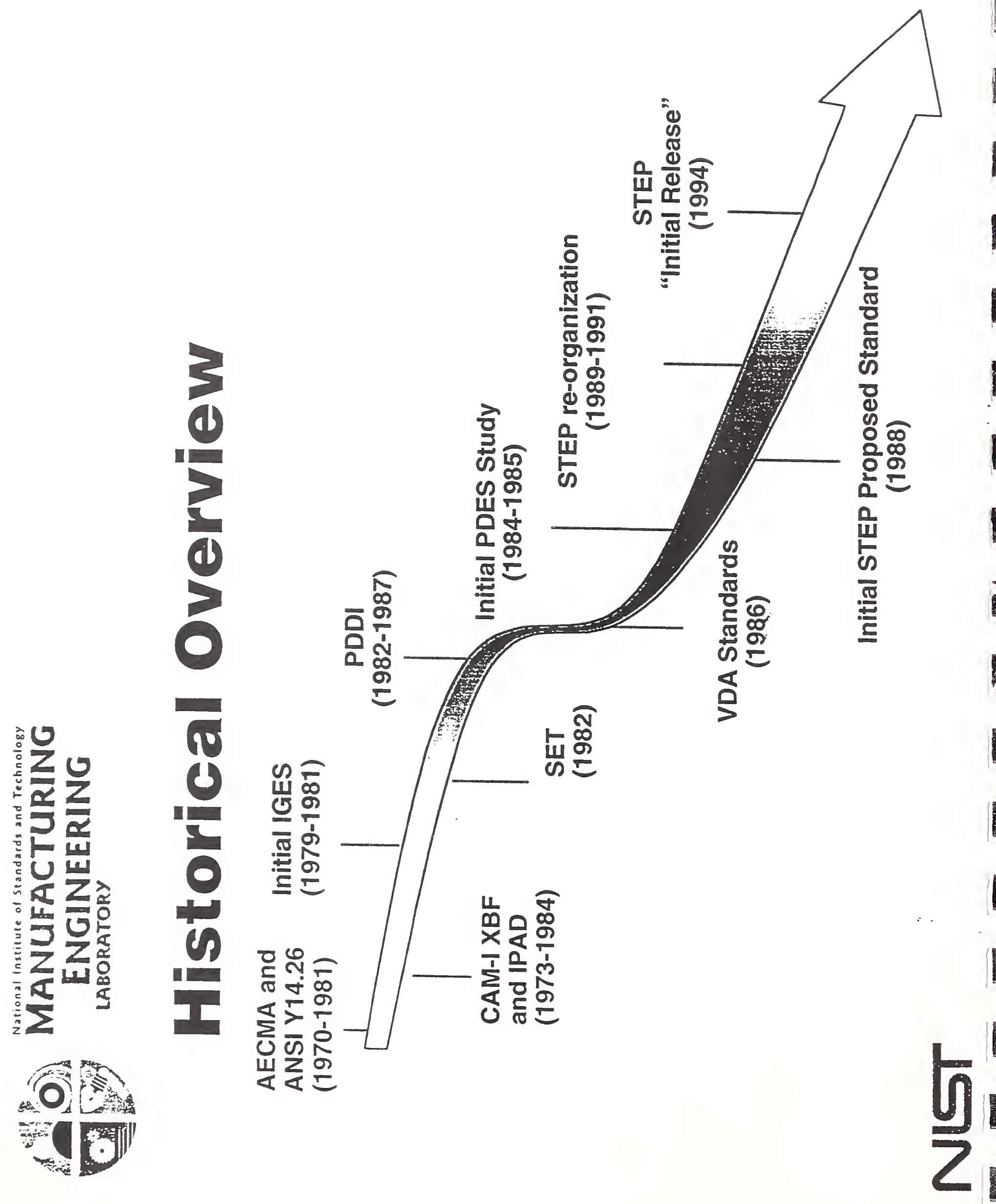



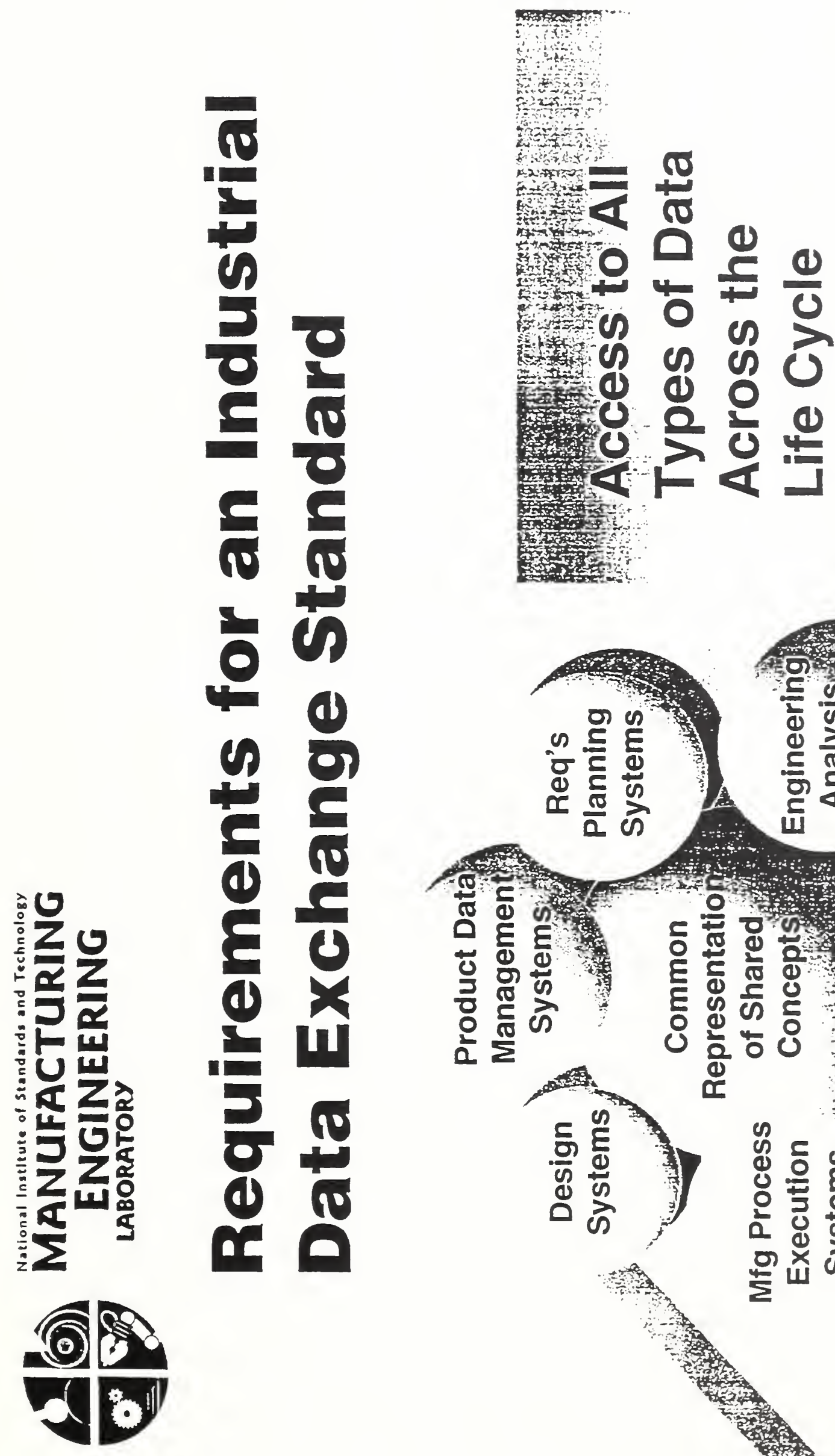


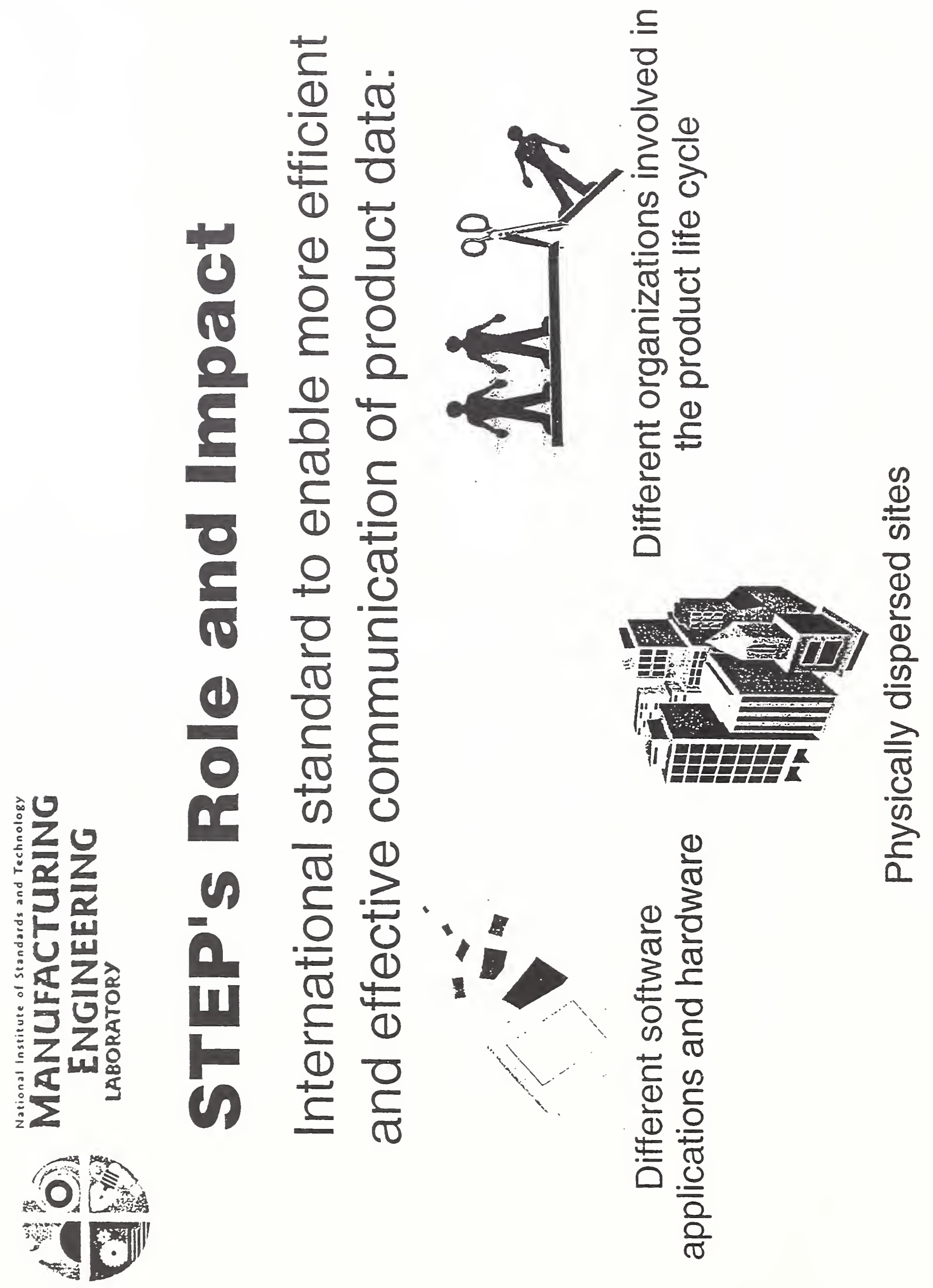




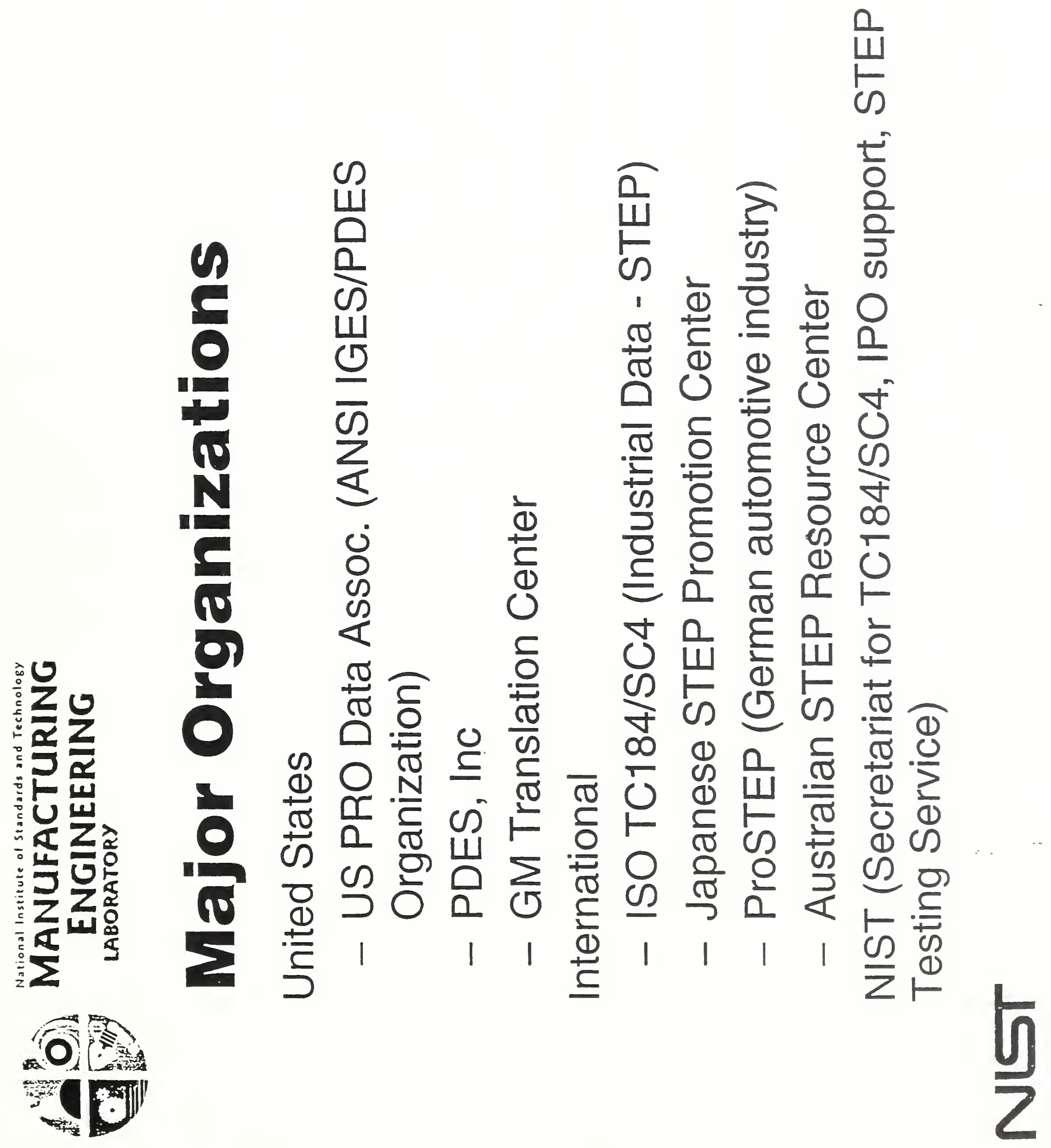




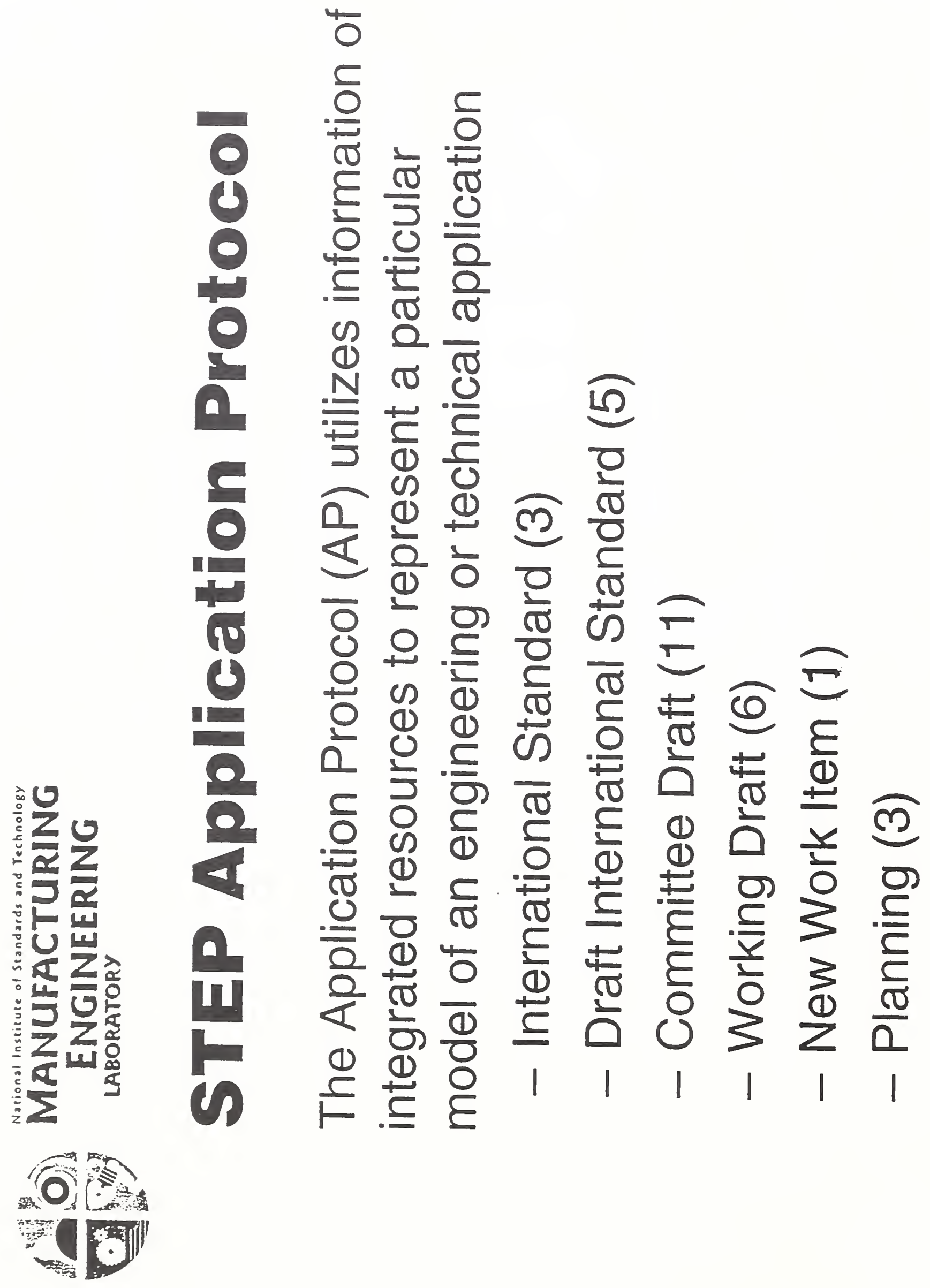



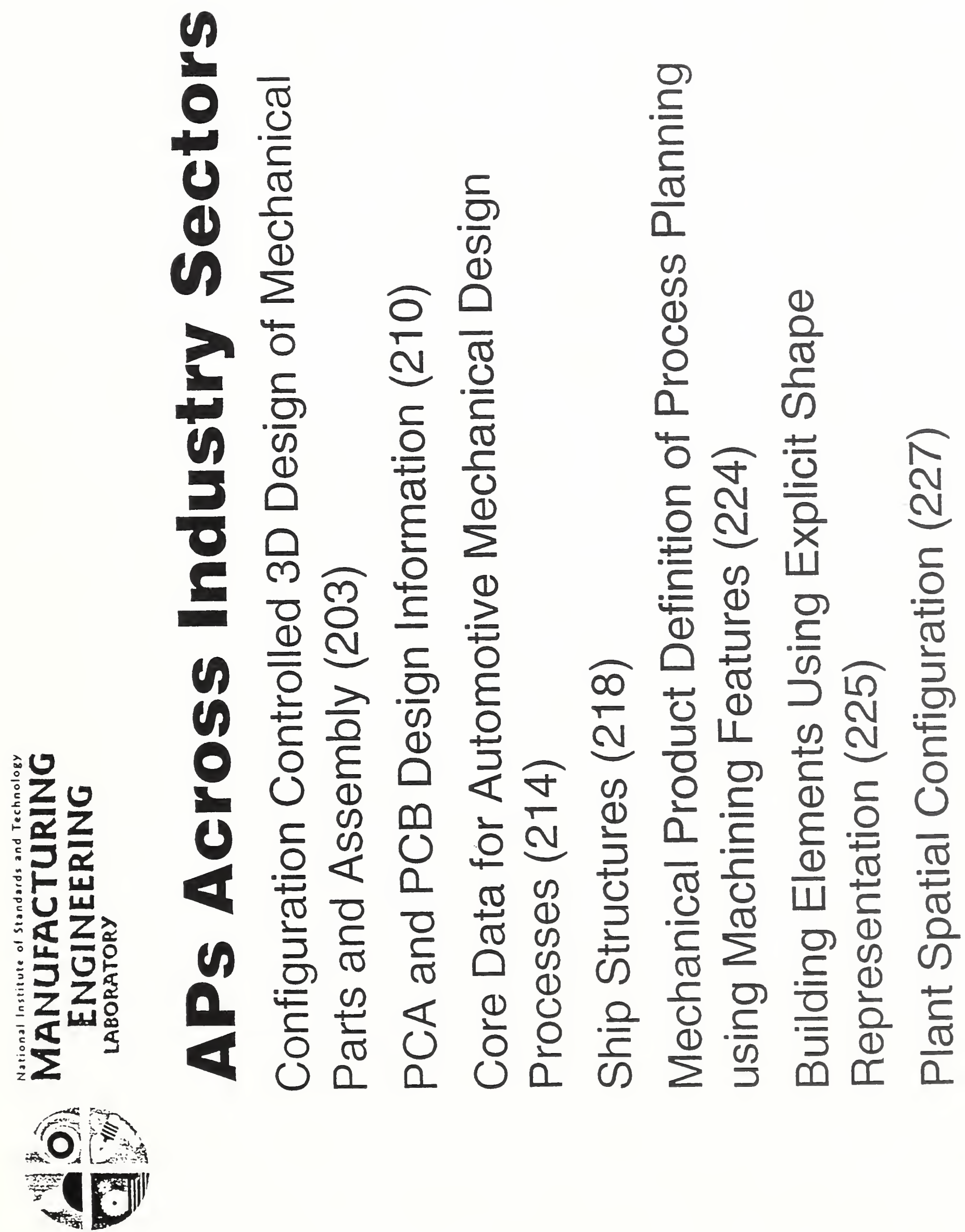


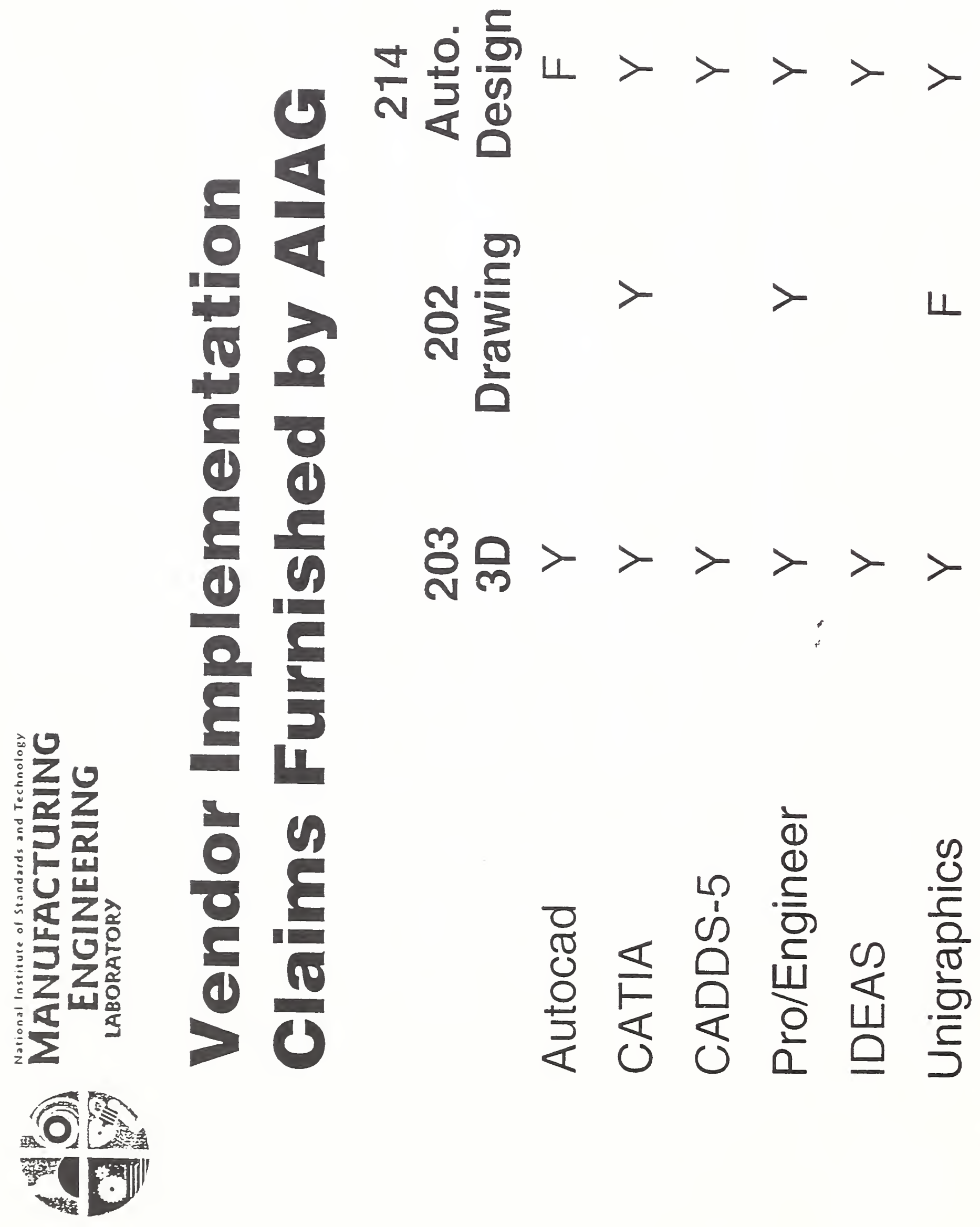




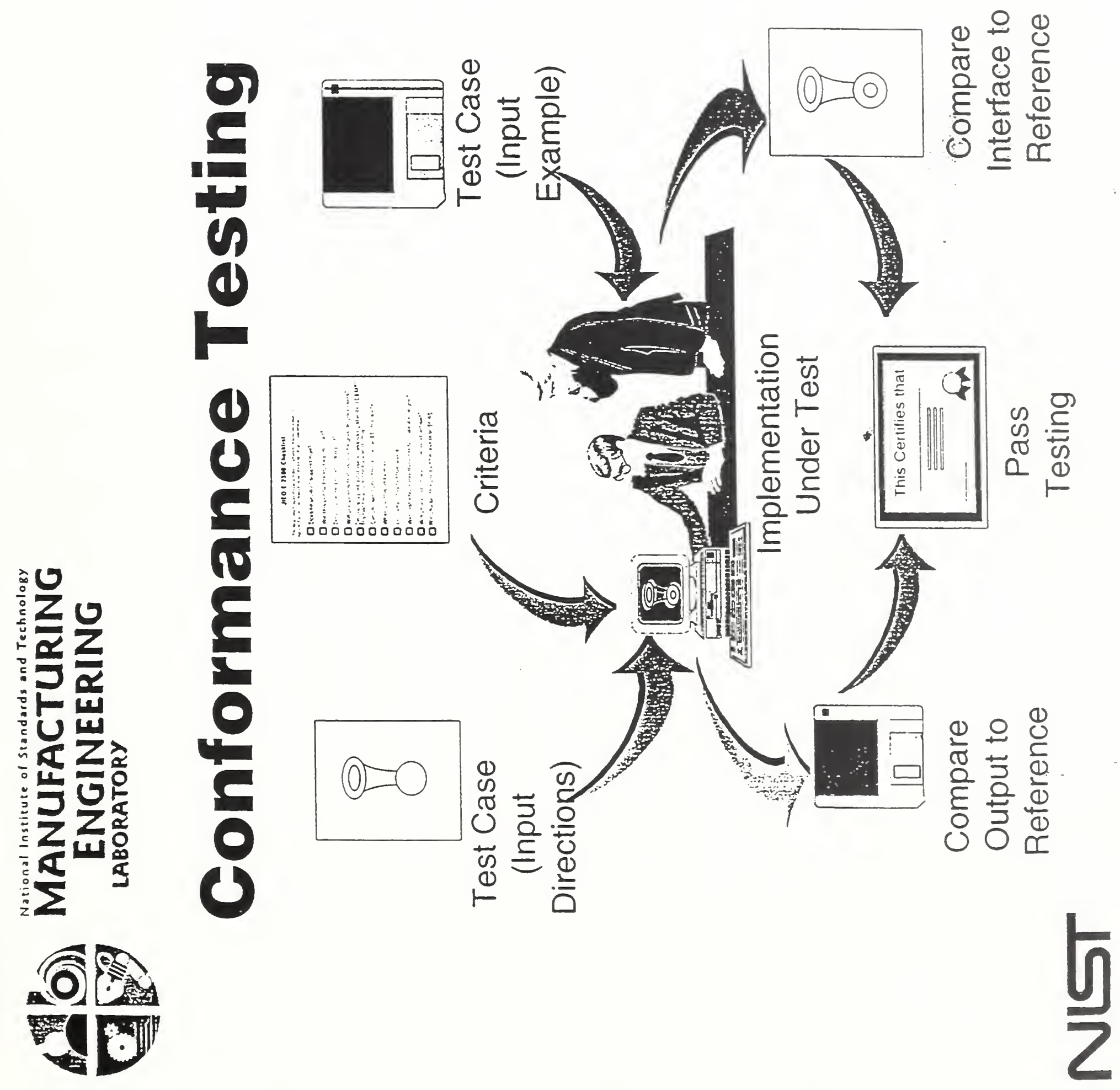




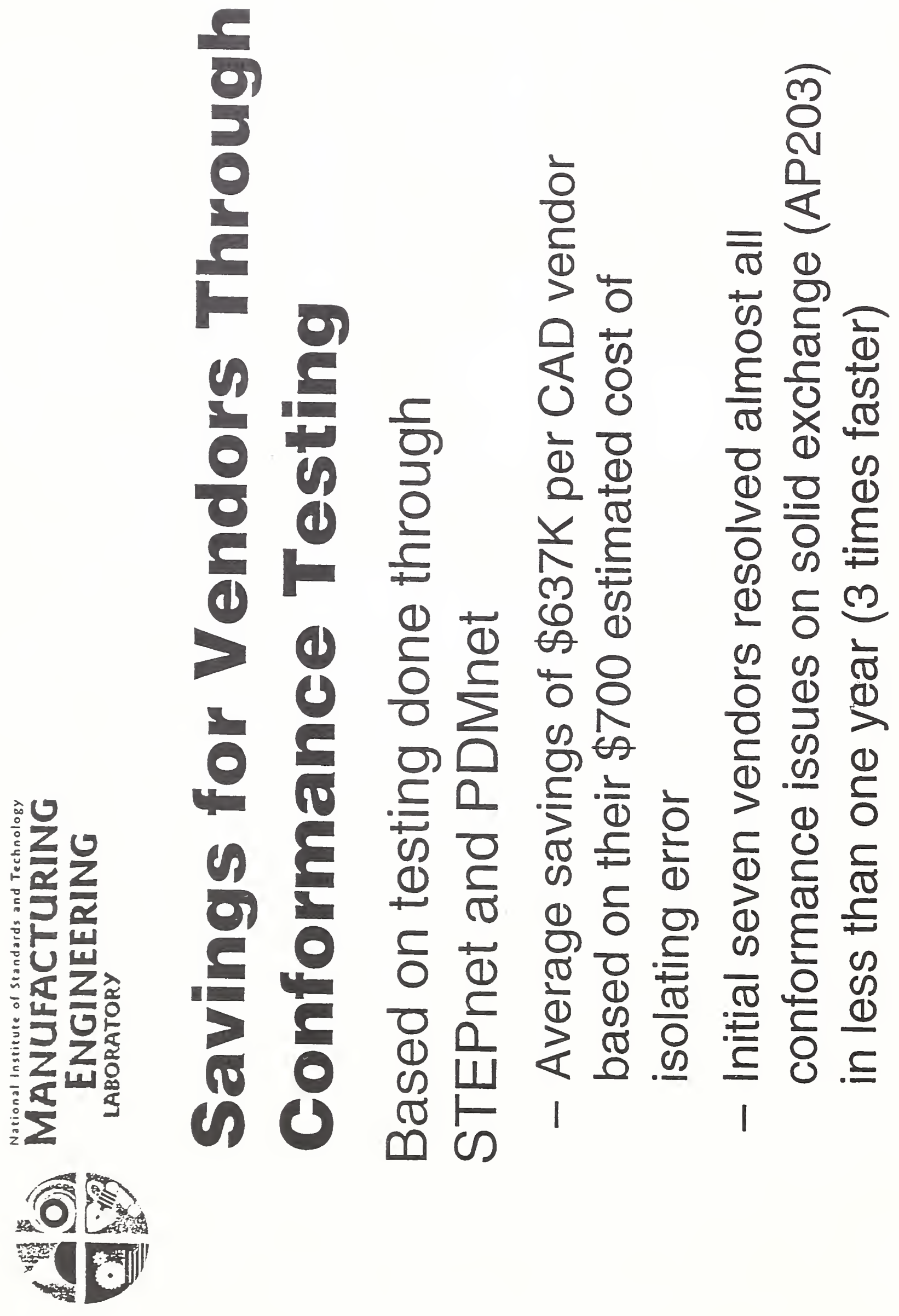




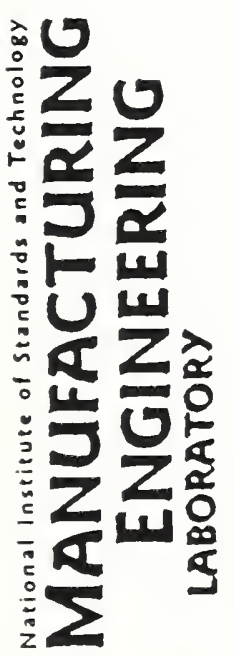

$\frac{n}{2}$

(1)

E

E

e

(1)

(1)

$>0 \frac{0}{0}$

0 을

(5) 8

$x$ 논

$\infty \mathrm{a}$

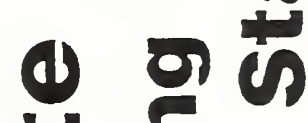

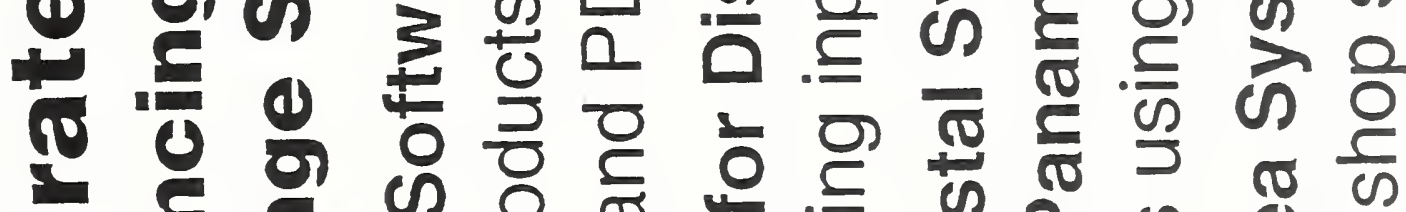

- $\omega$ 元

$20 \frac{10}{0}$

- 40 은

0 的

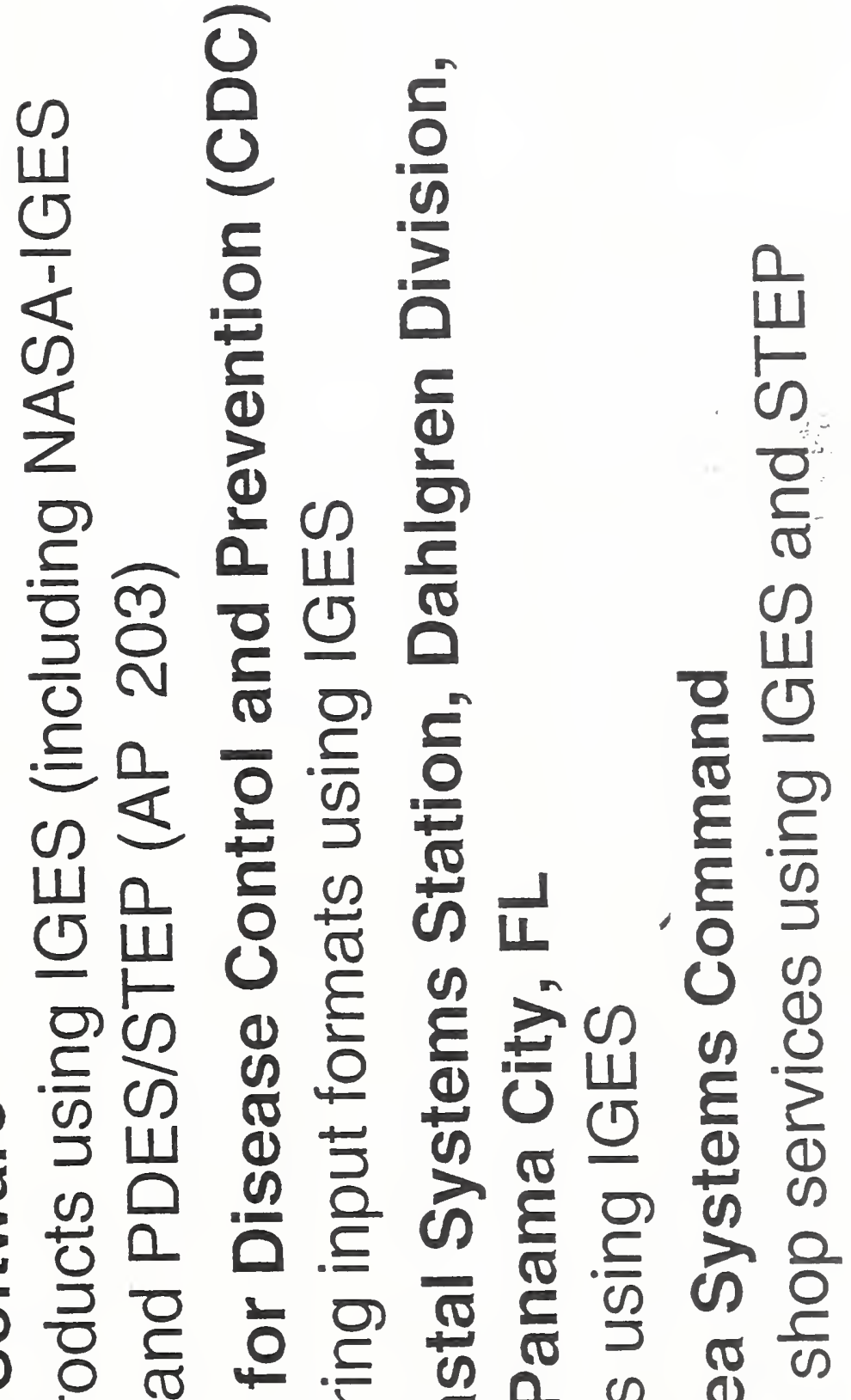

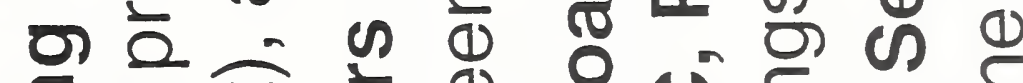

बै

ง 

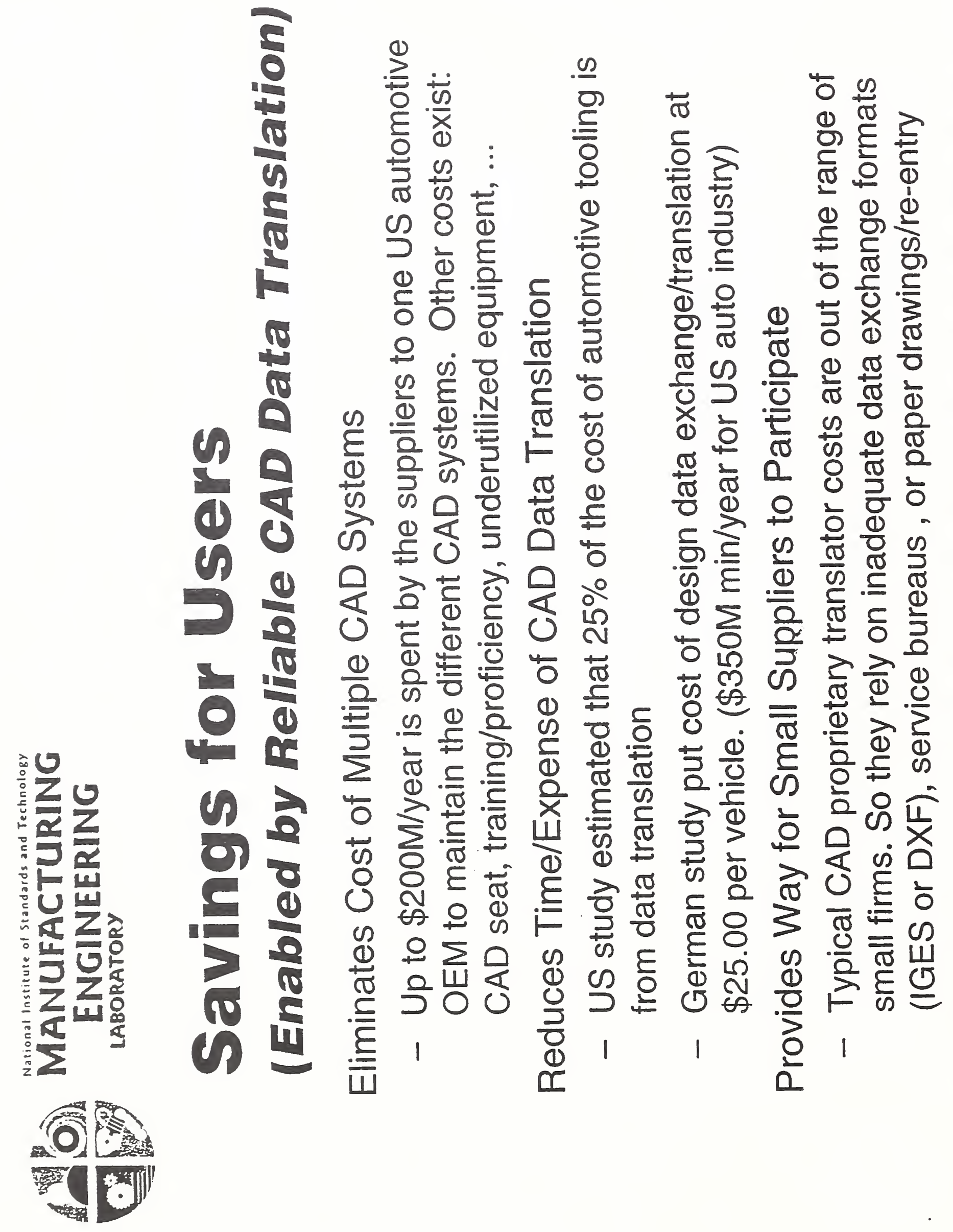


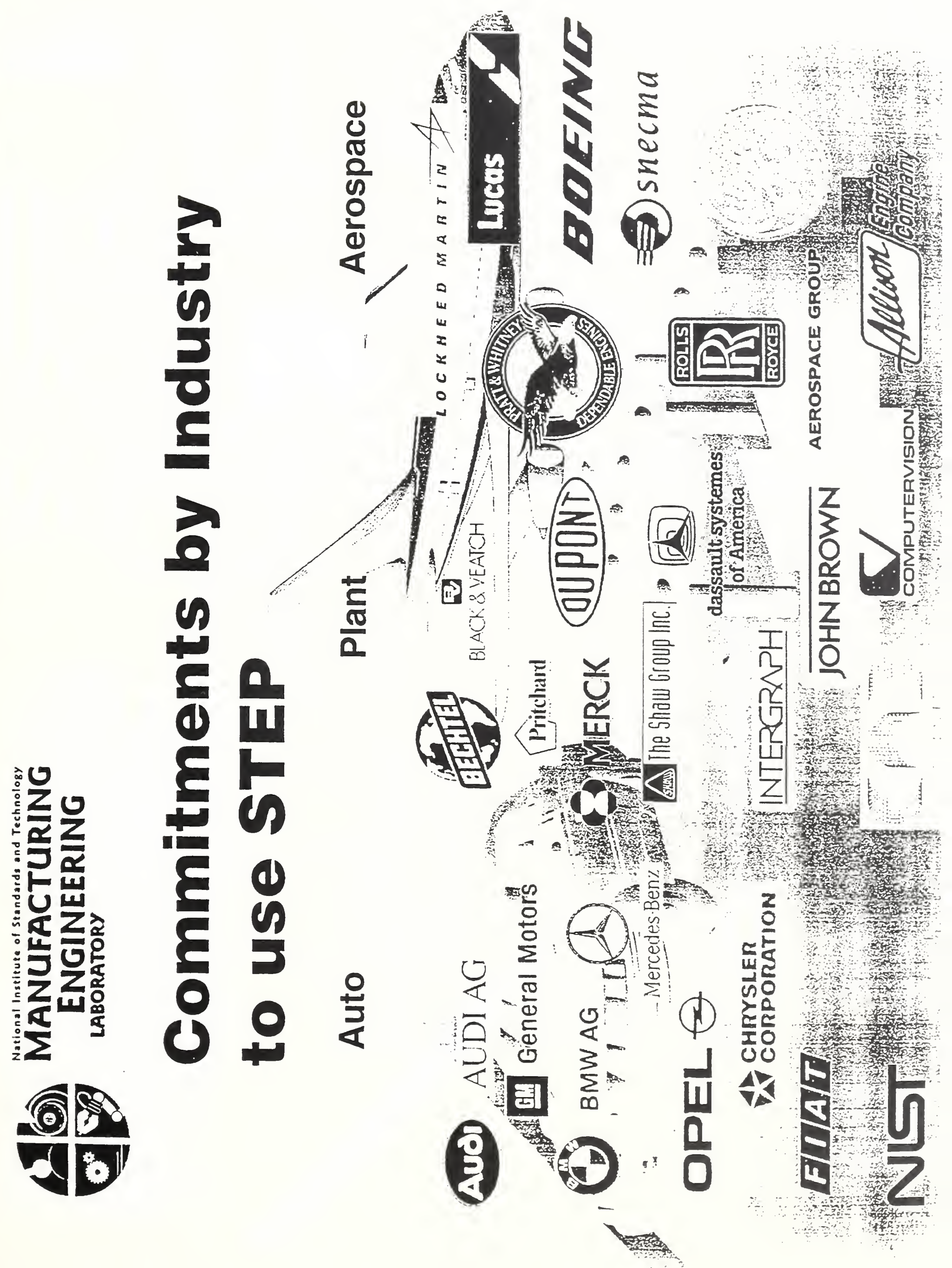




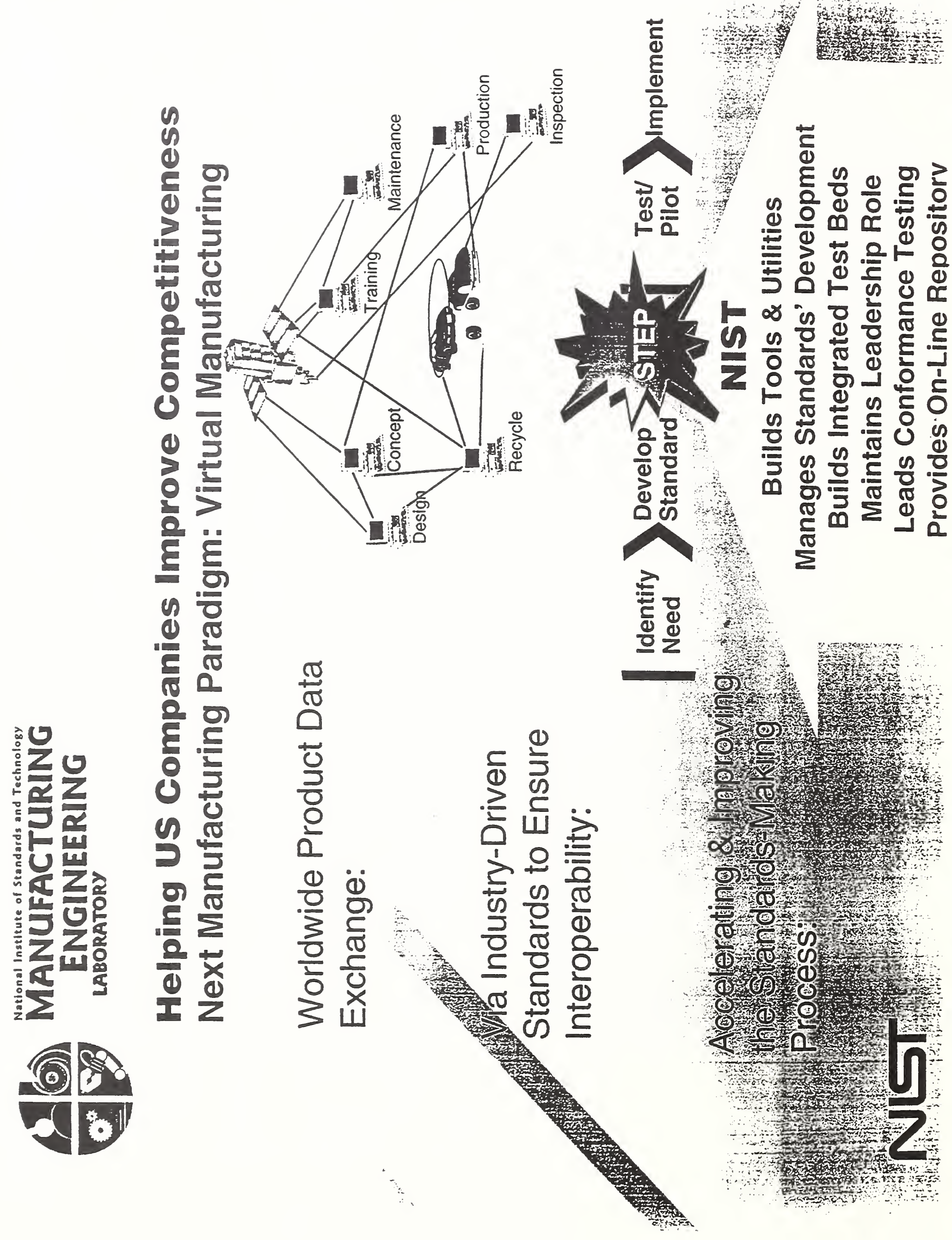




\section{Section 6}

National strategic Standards Panel 
[l]

II II<smiles>[C+]1[C+]C=C1</smiles><smiles>C1=CCCCC1</smiles>
.

$E_{z}$ C.<smiles>[CH]1C=C1</smiles><smiles>[Li][Mg]</smiles>
F.

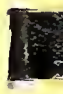
1 (4) 


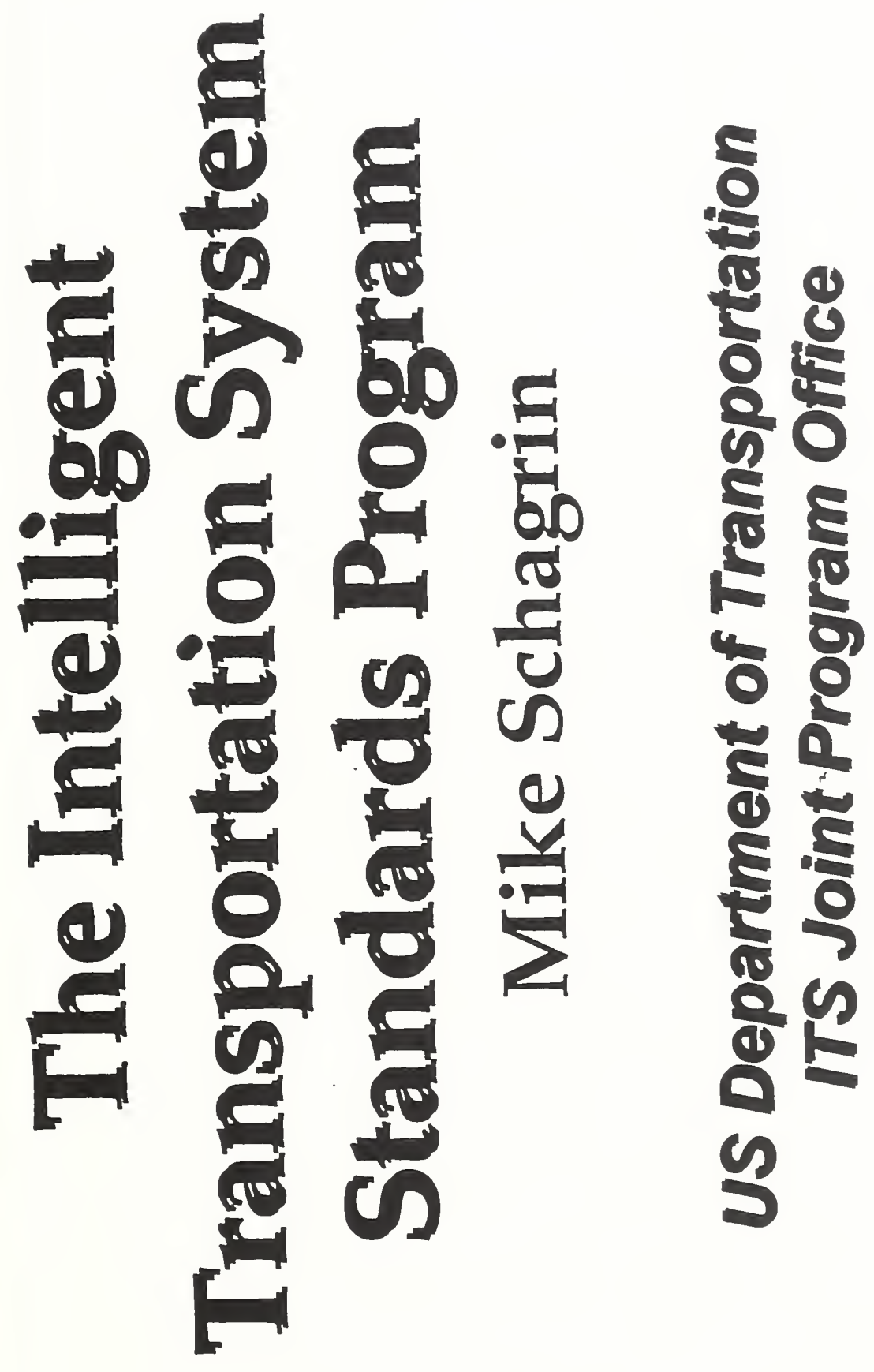




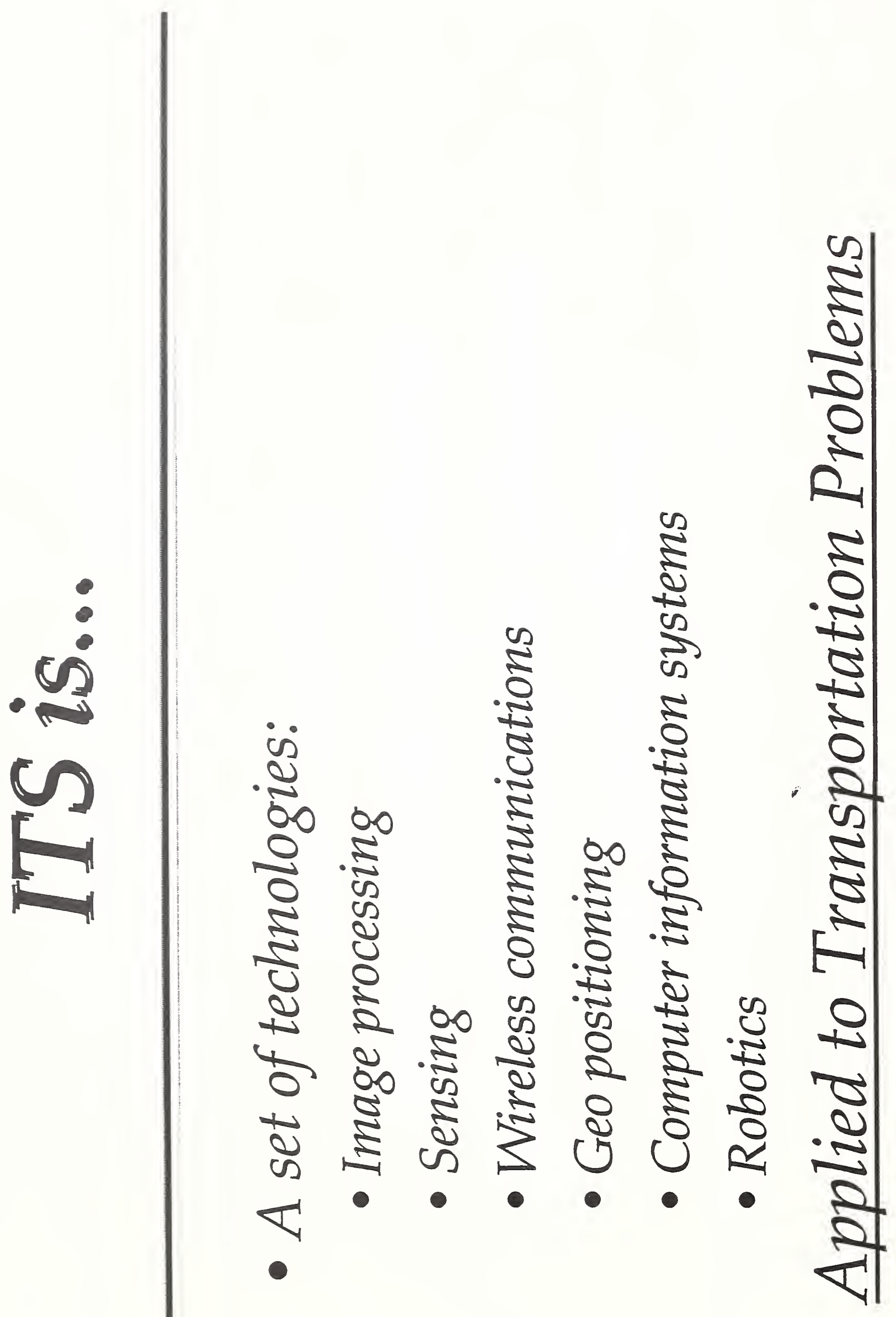




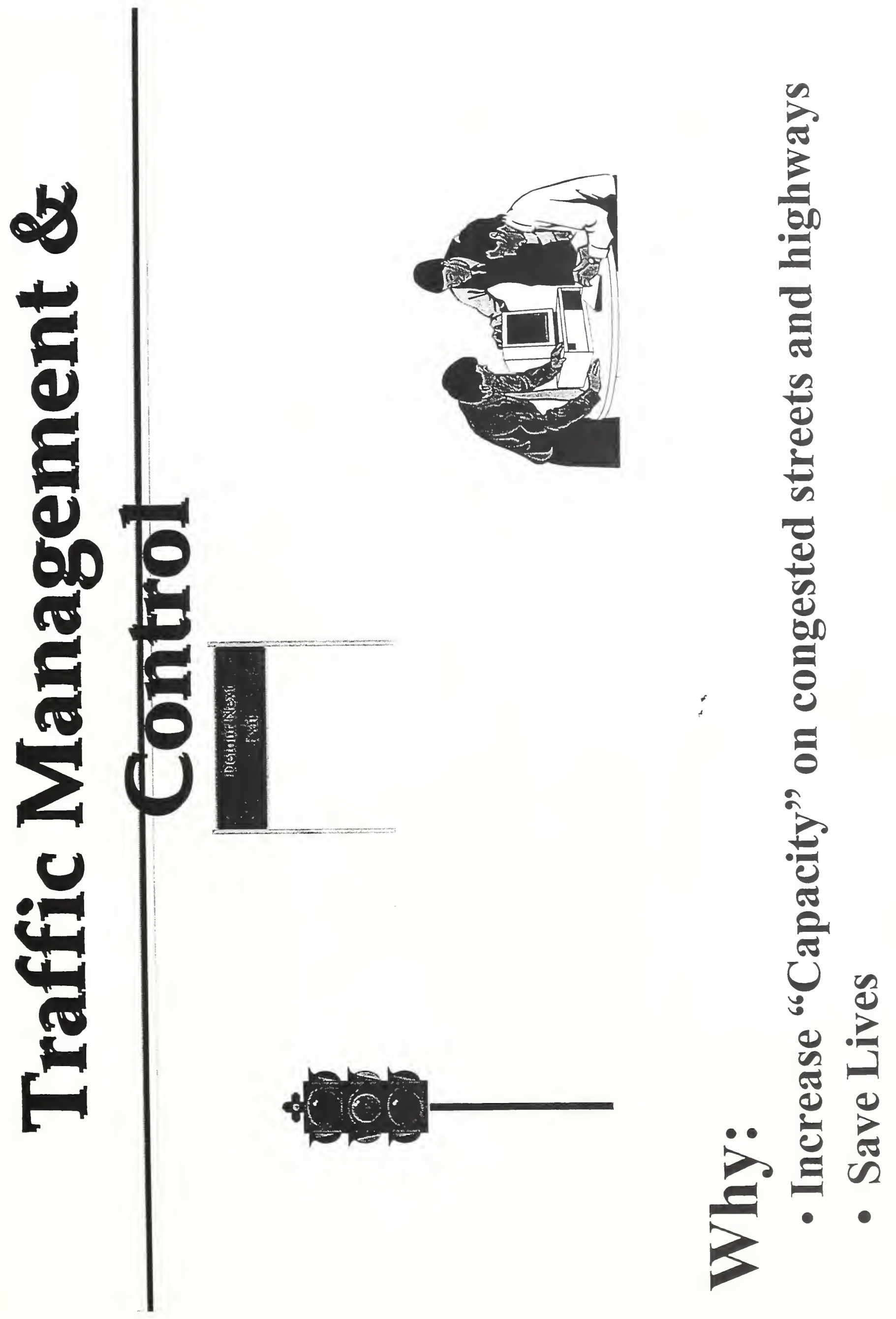




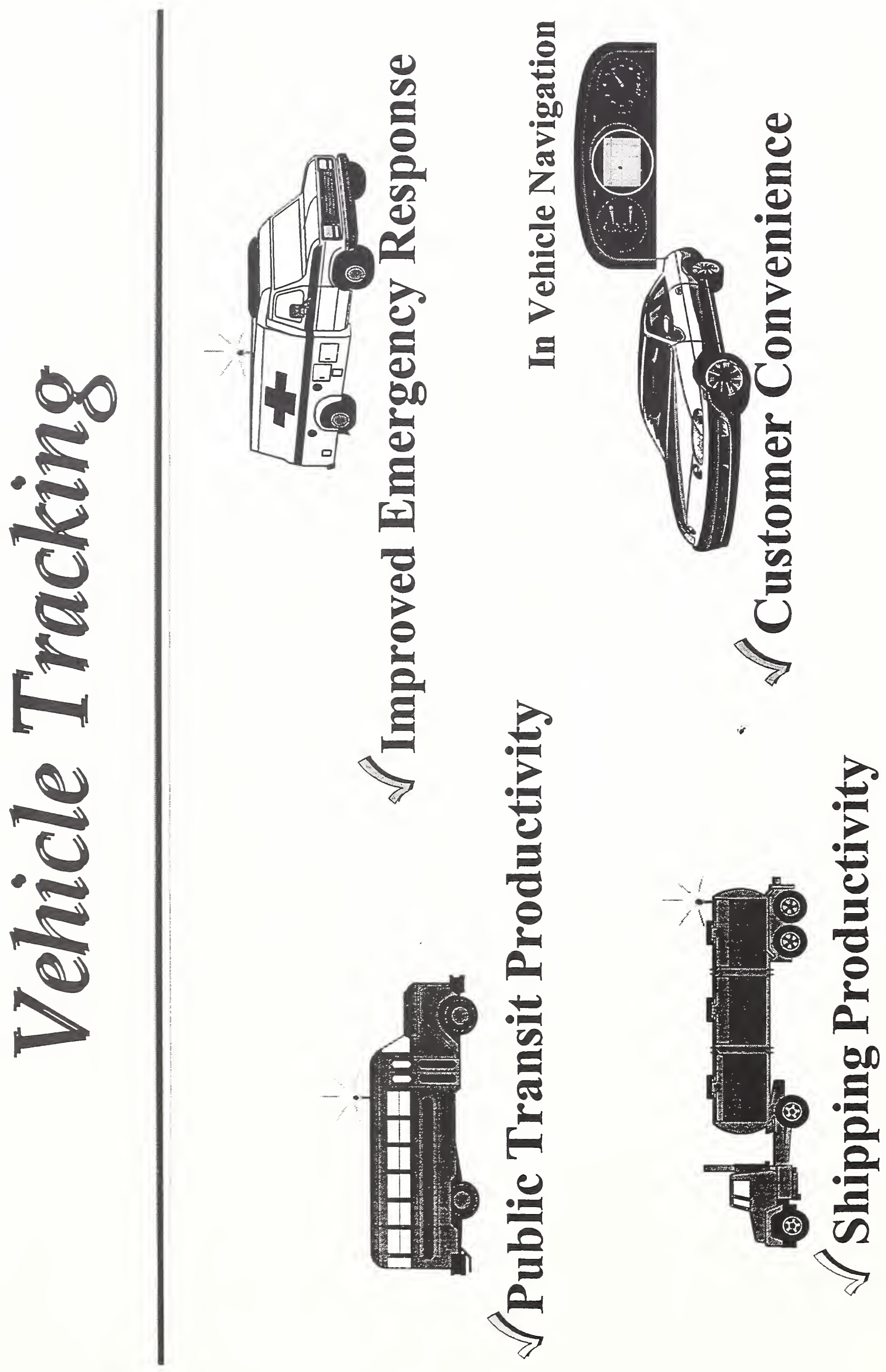




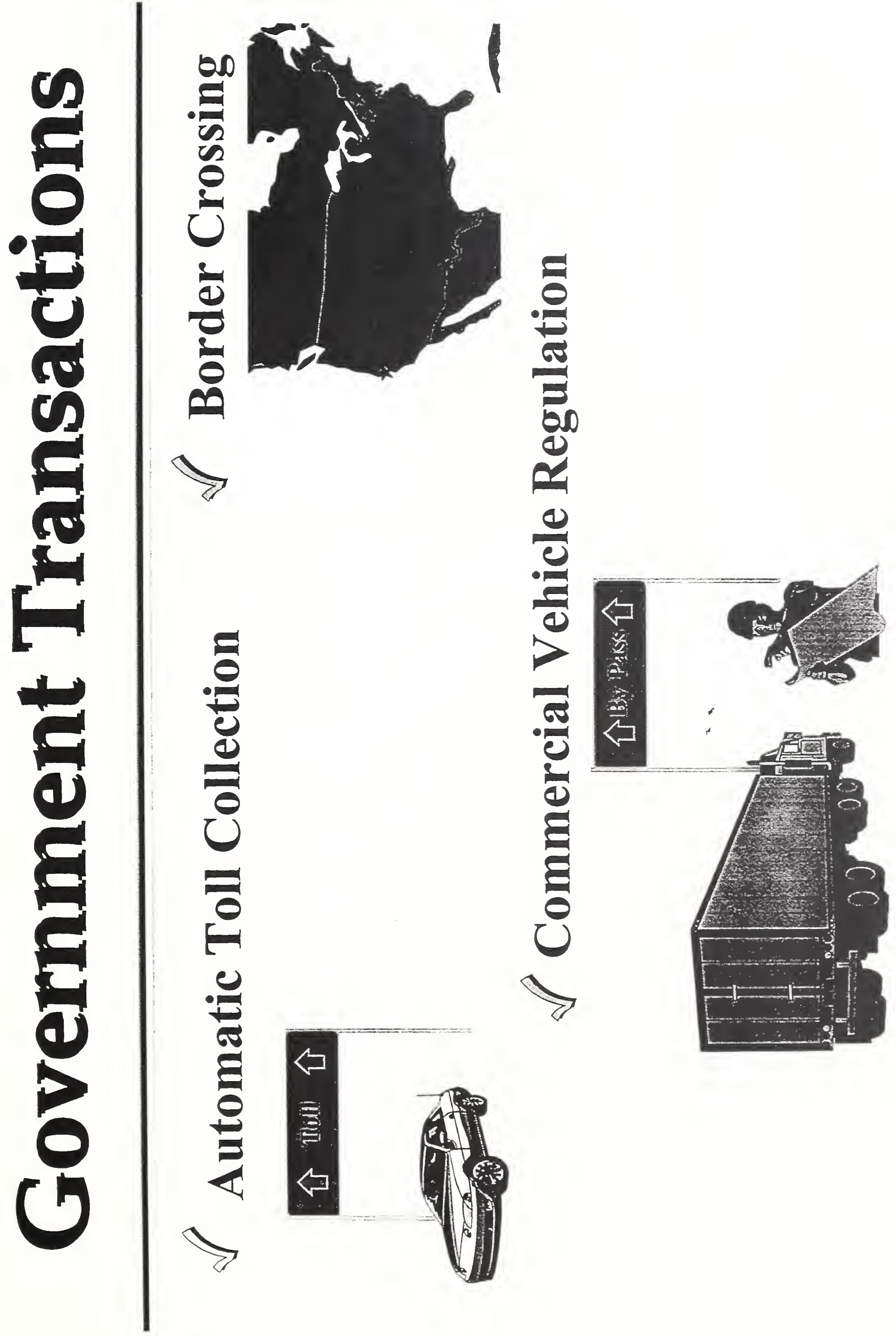



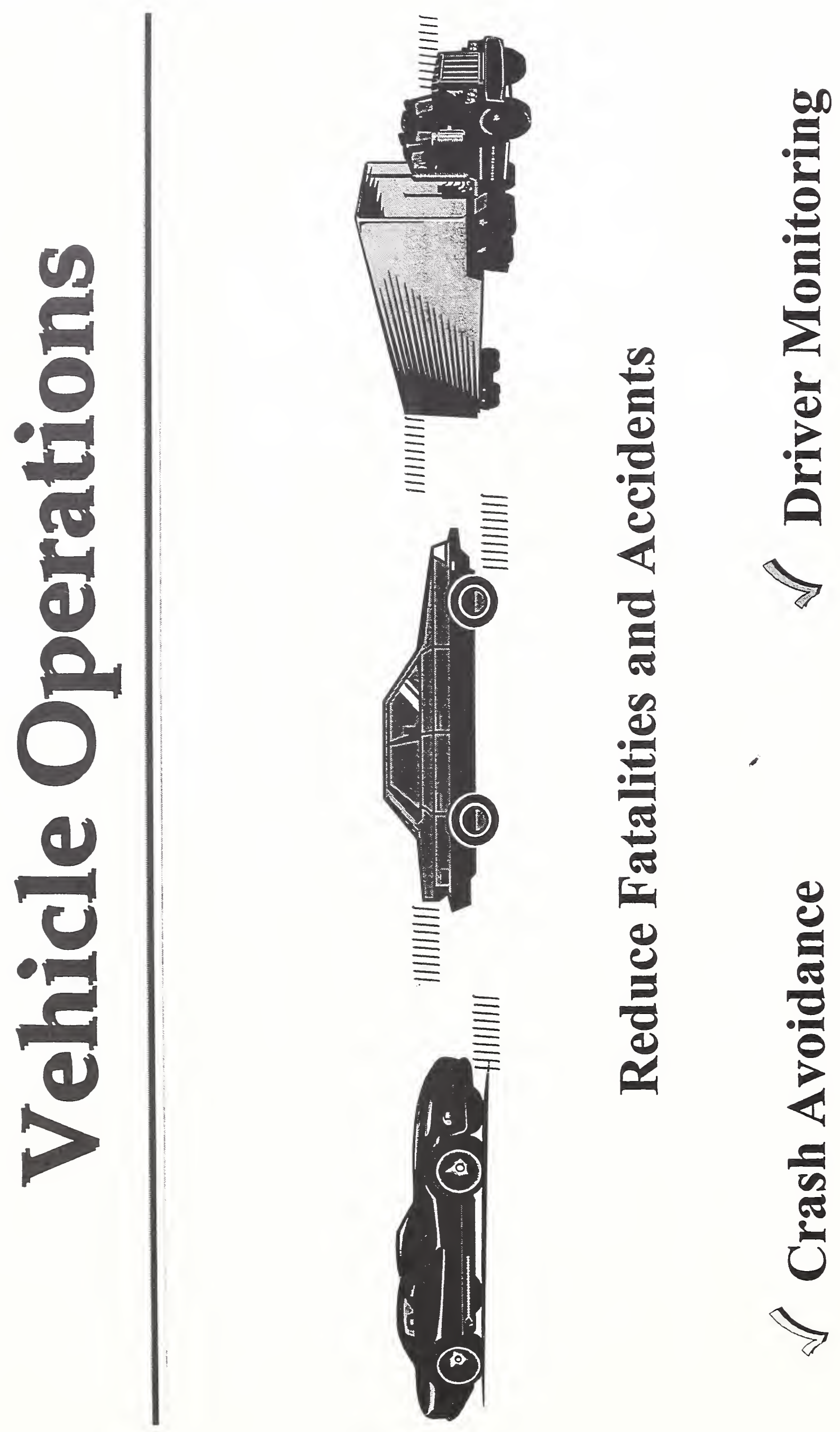

[1]
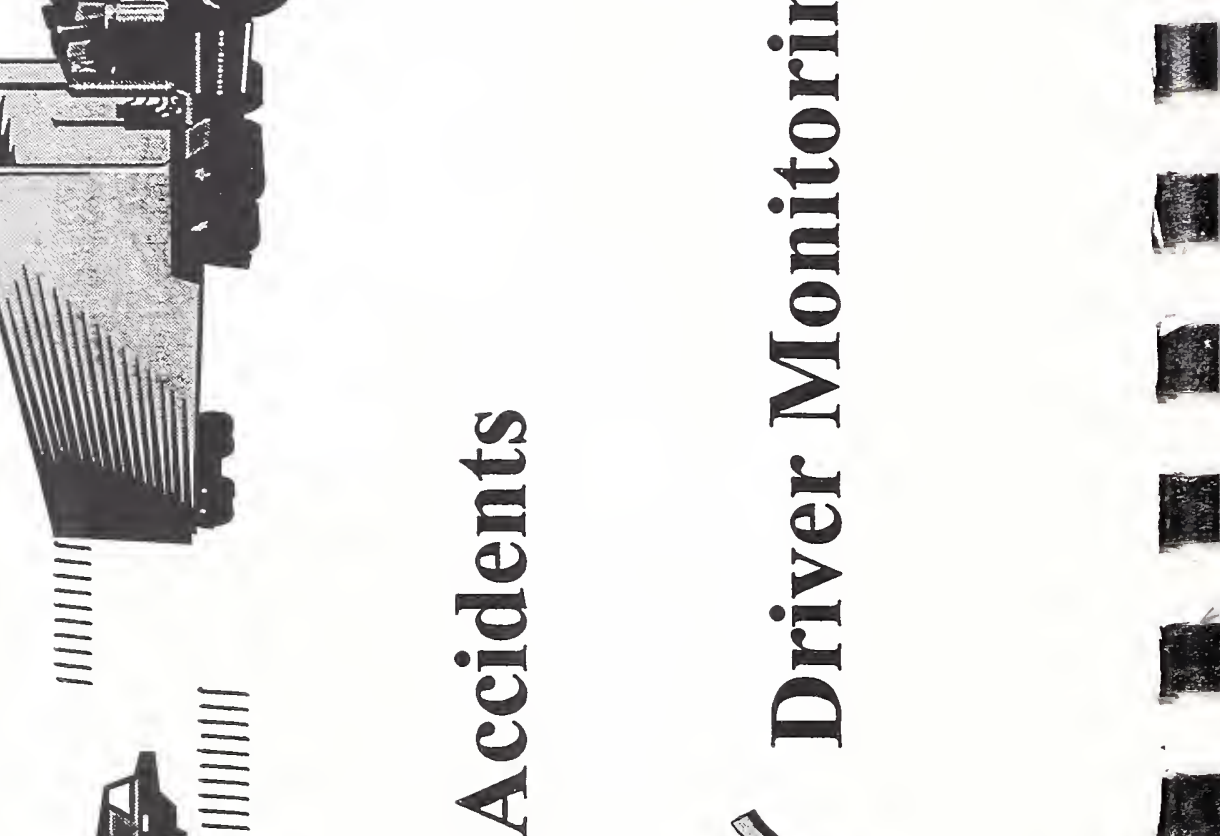

E
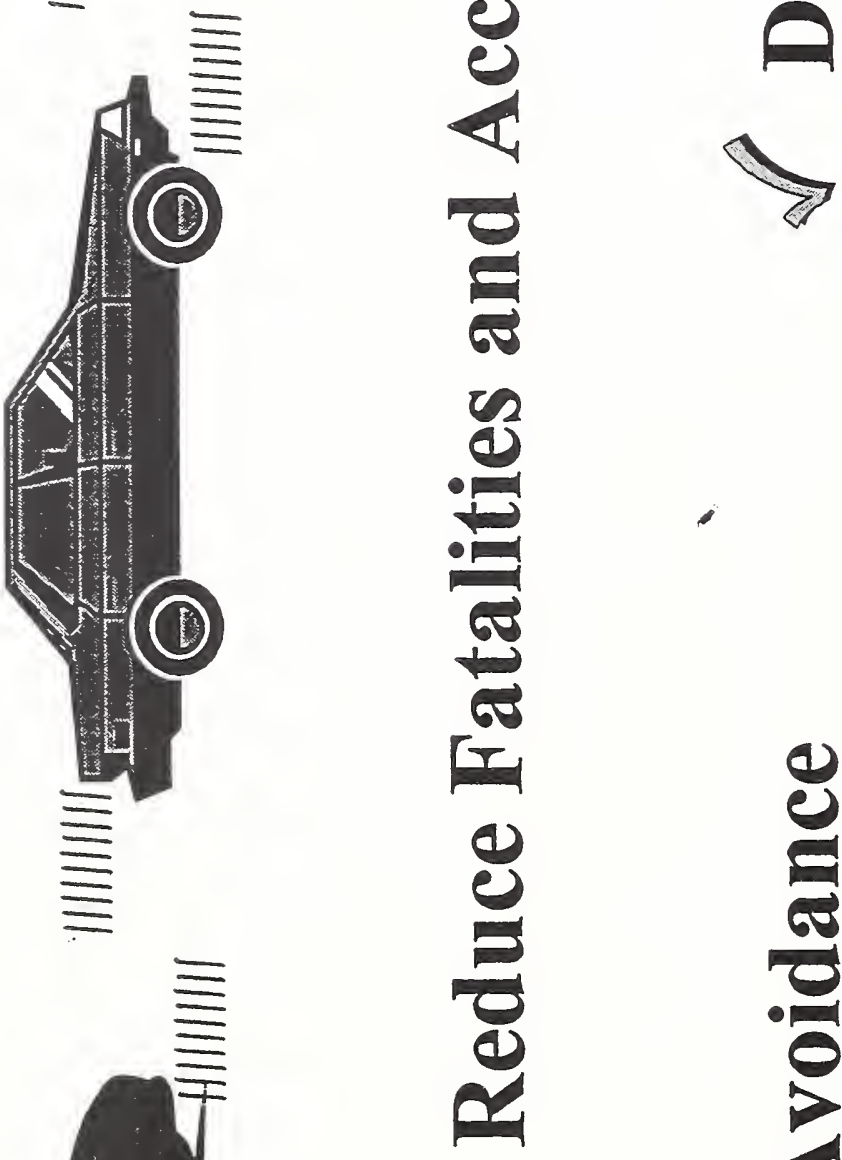

W
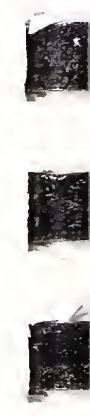

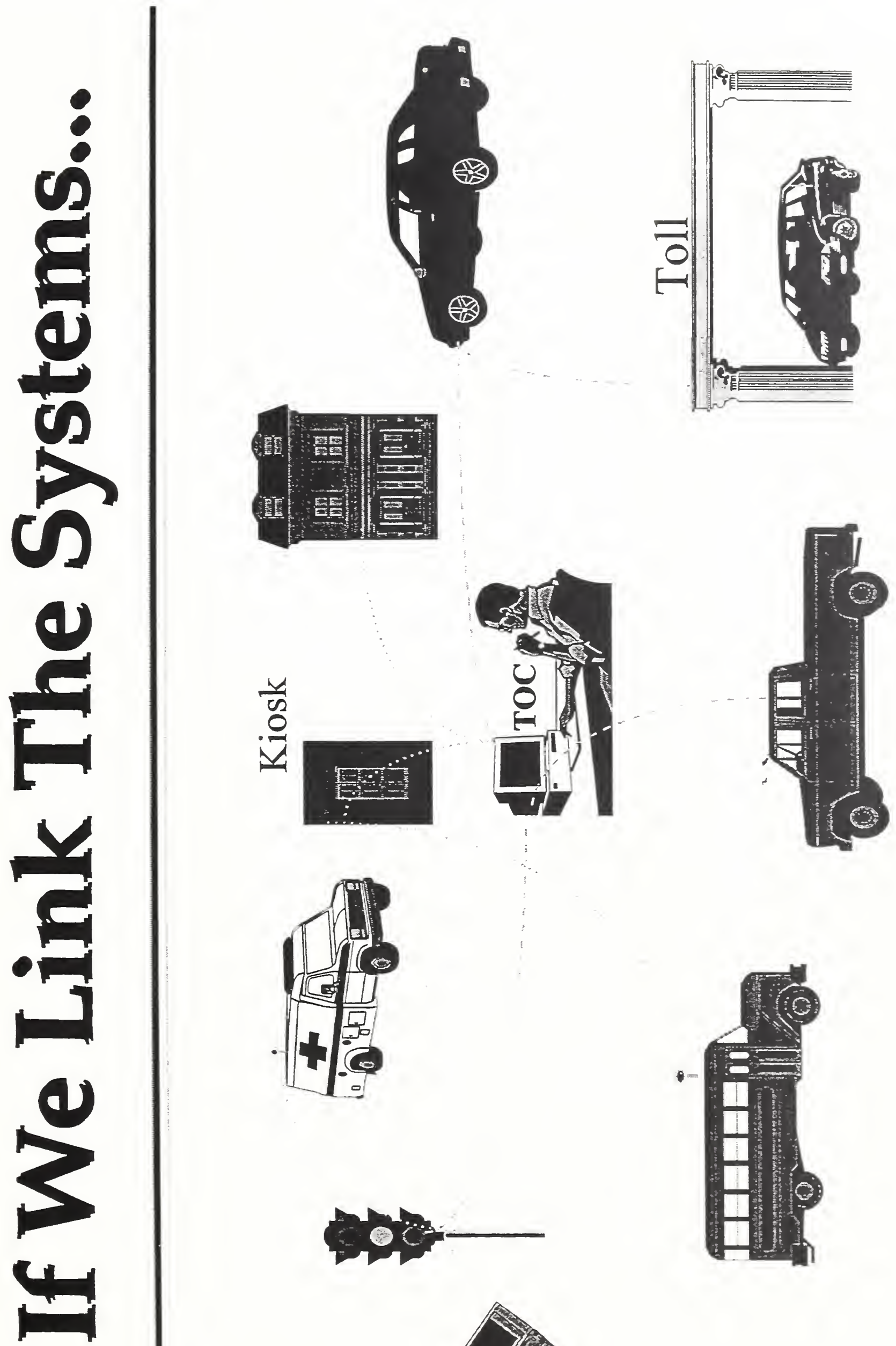

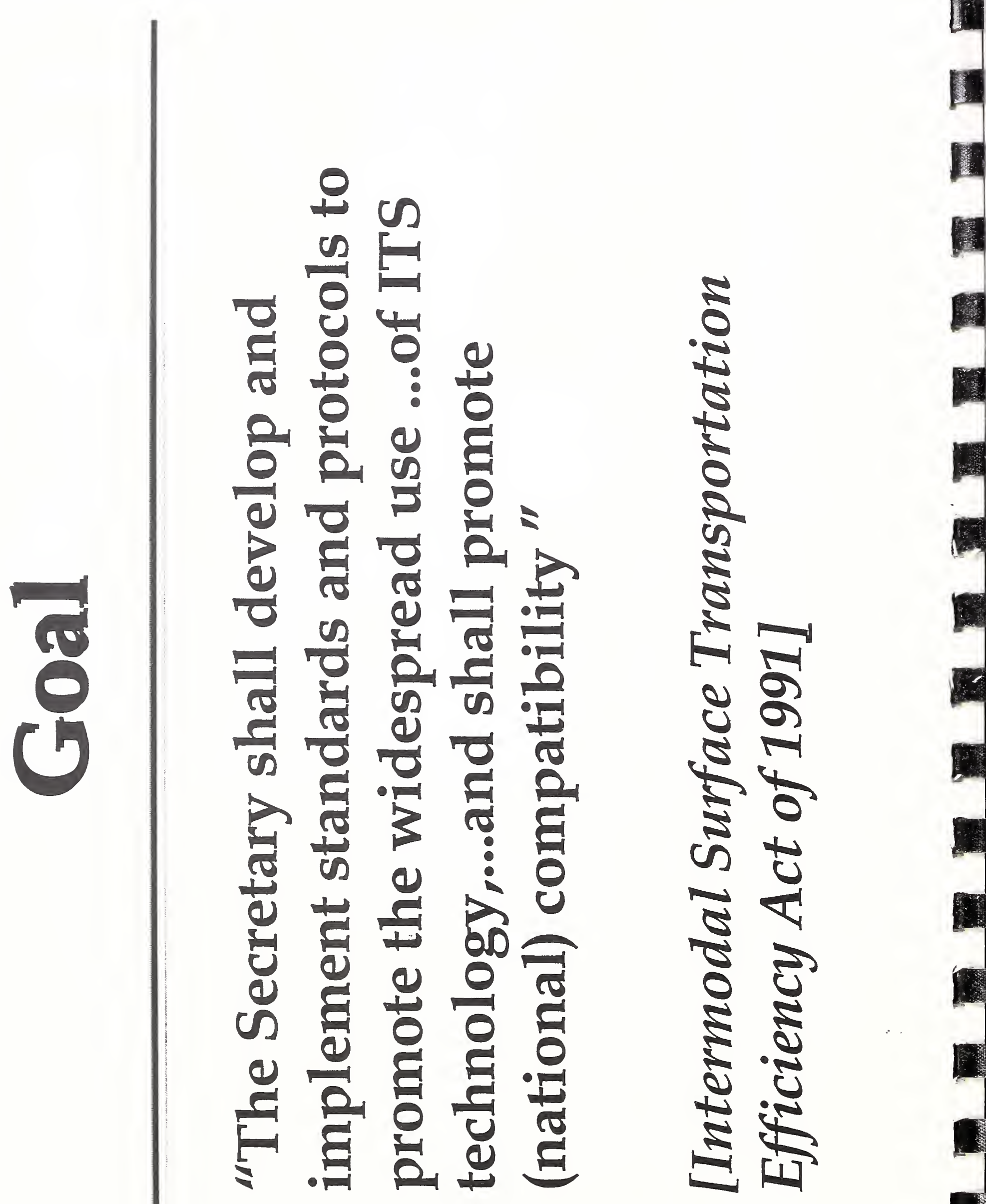

a)

(a)

0

क ज्ञ तै

त्य

To

Us Ua

os 0

$\geqslant$ ar

त)

(d)

(a)

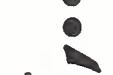

2

त्य

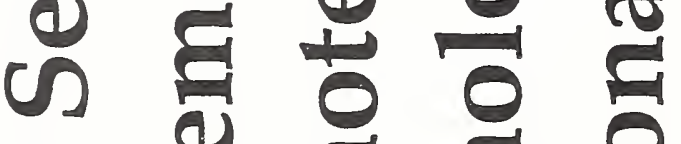

a) 0 है

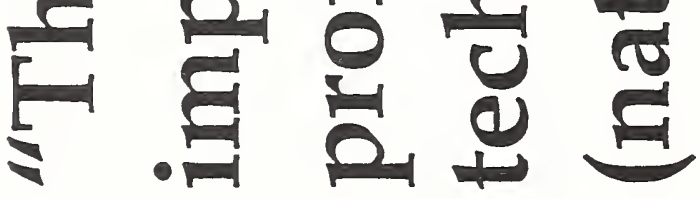

(5) 


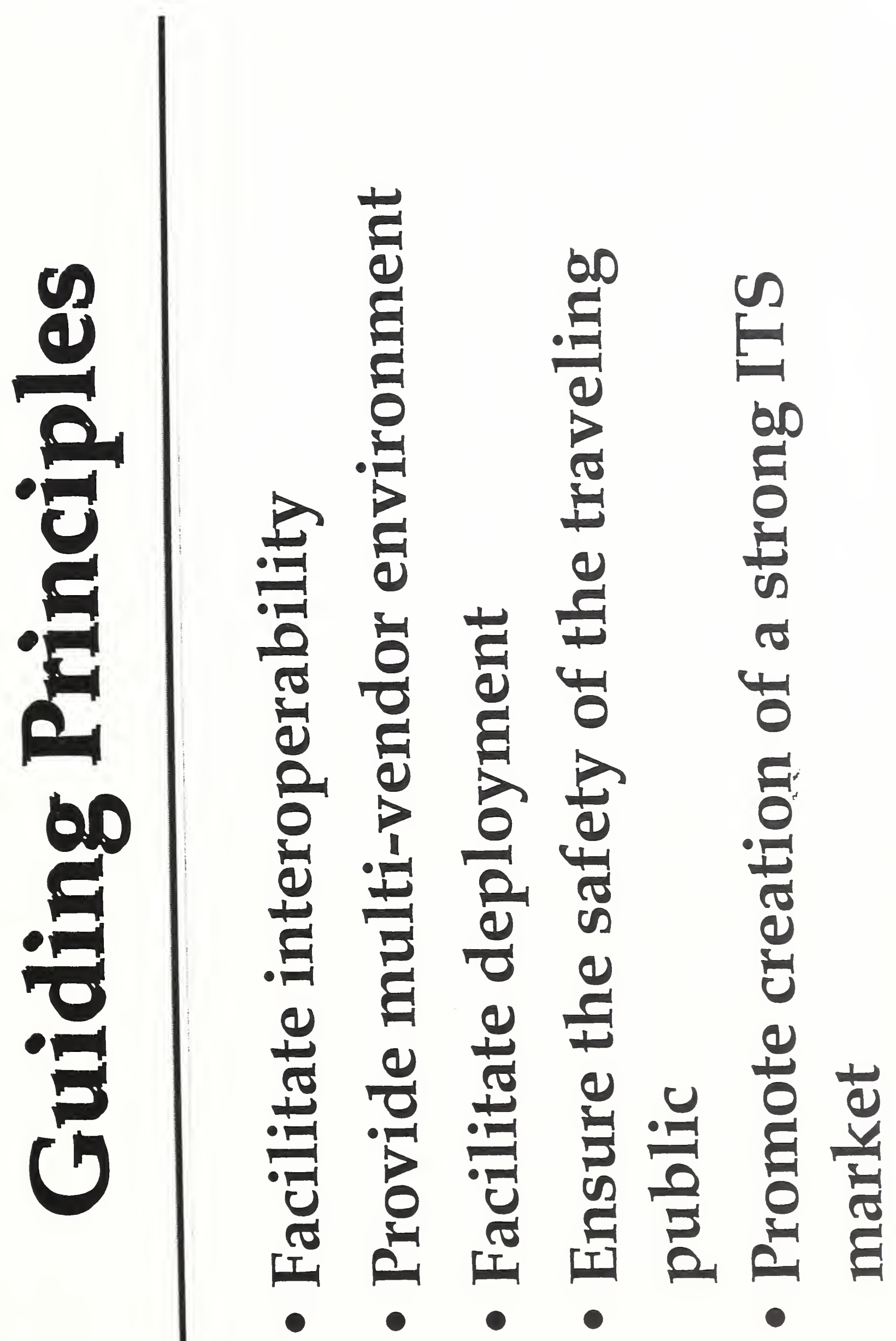




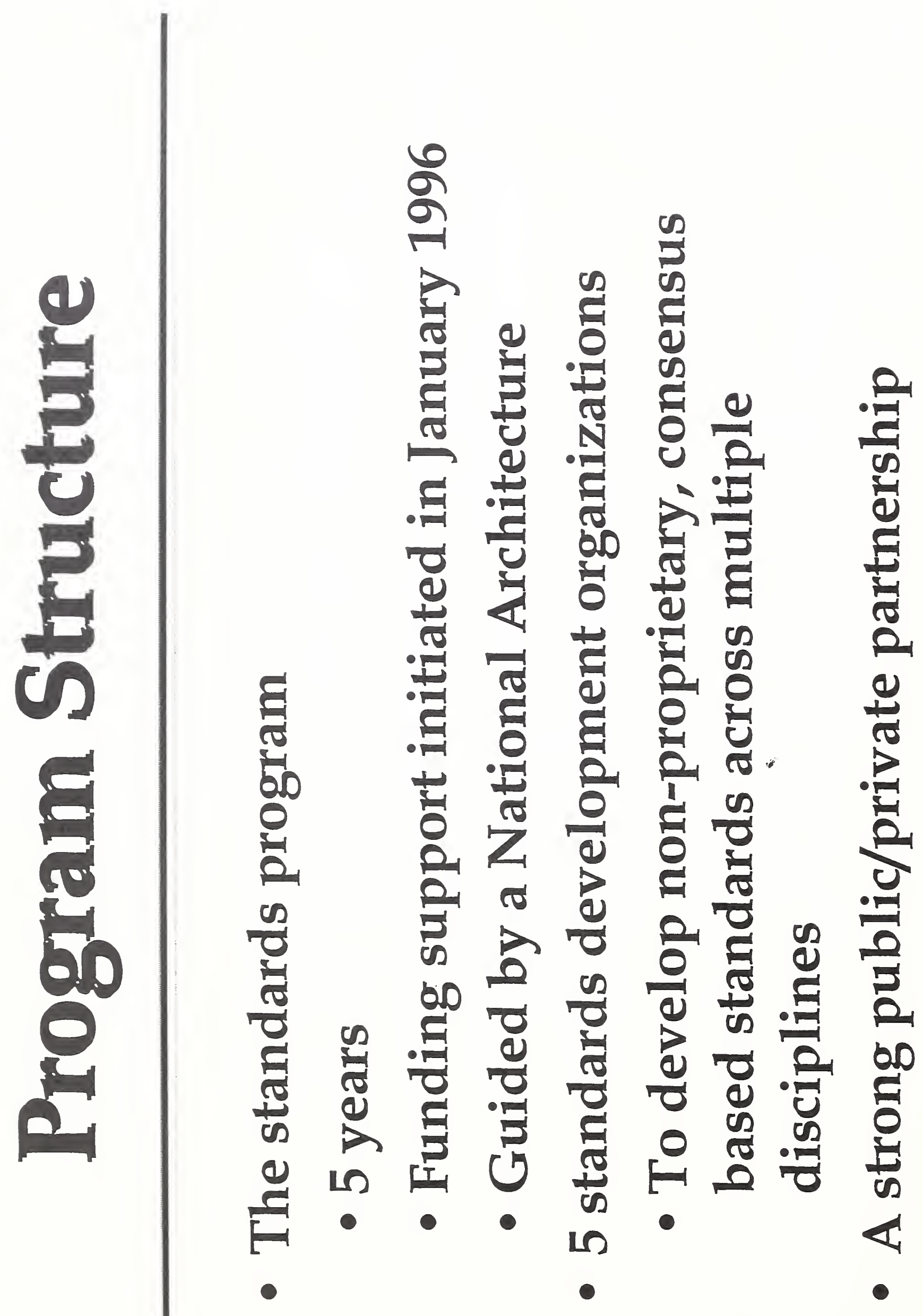




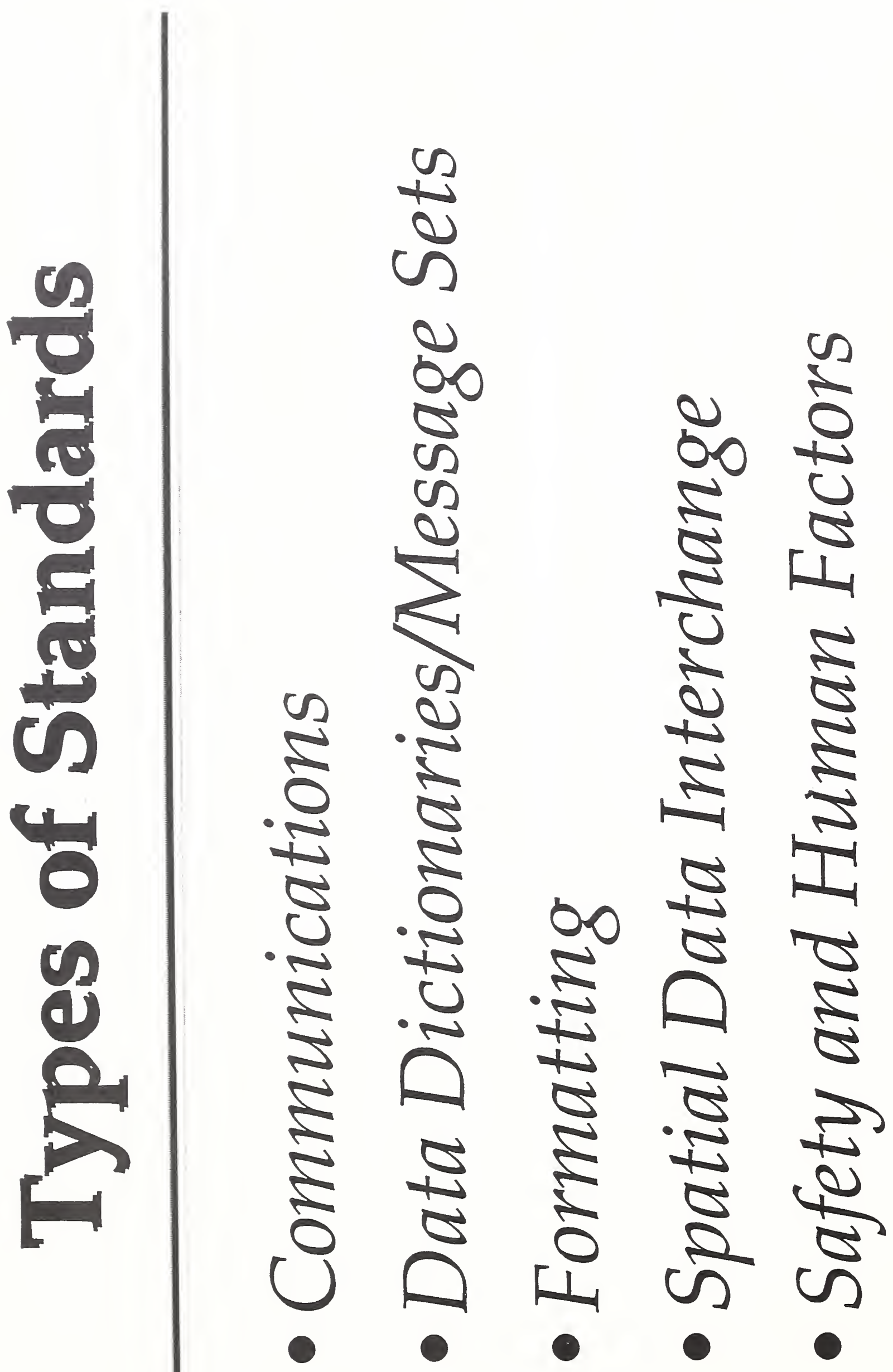




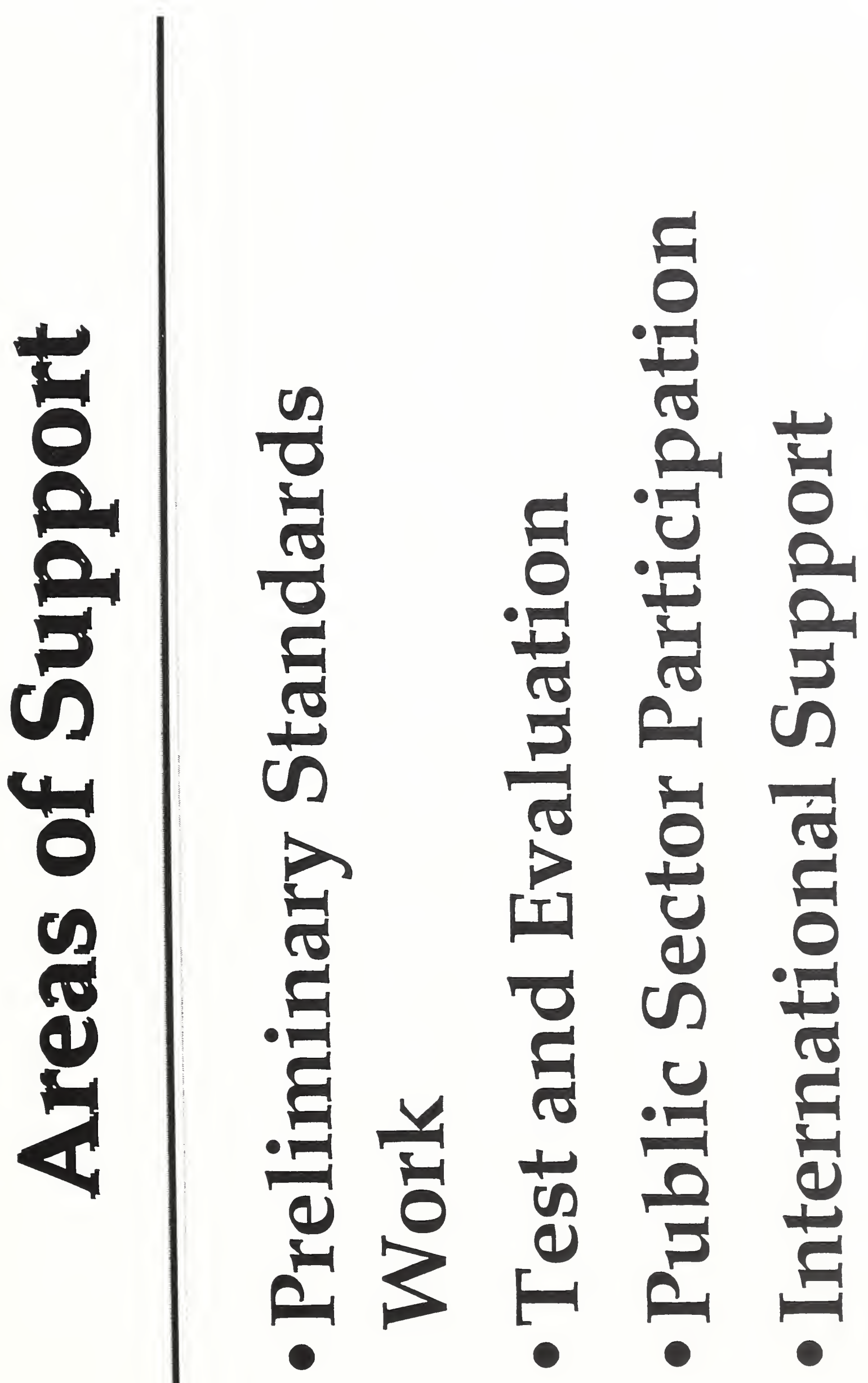



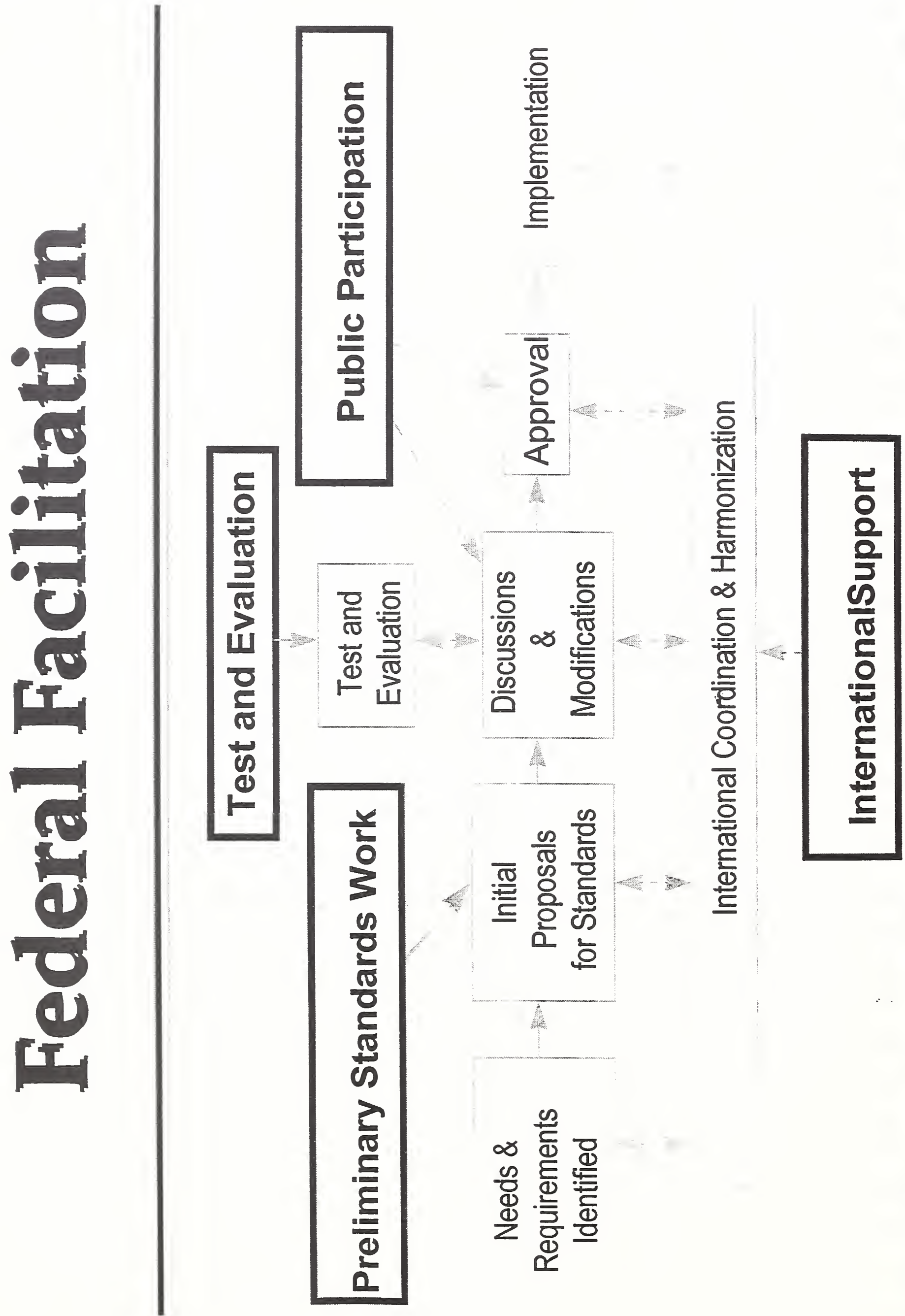
[0

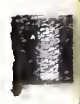

程

.

tis

군

.

晦

I

.

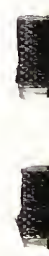

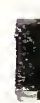

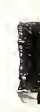





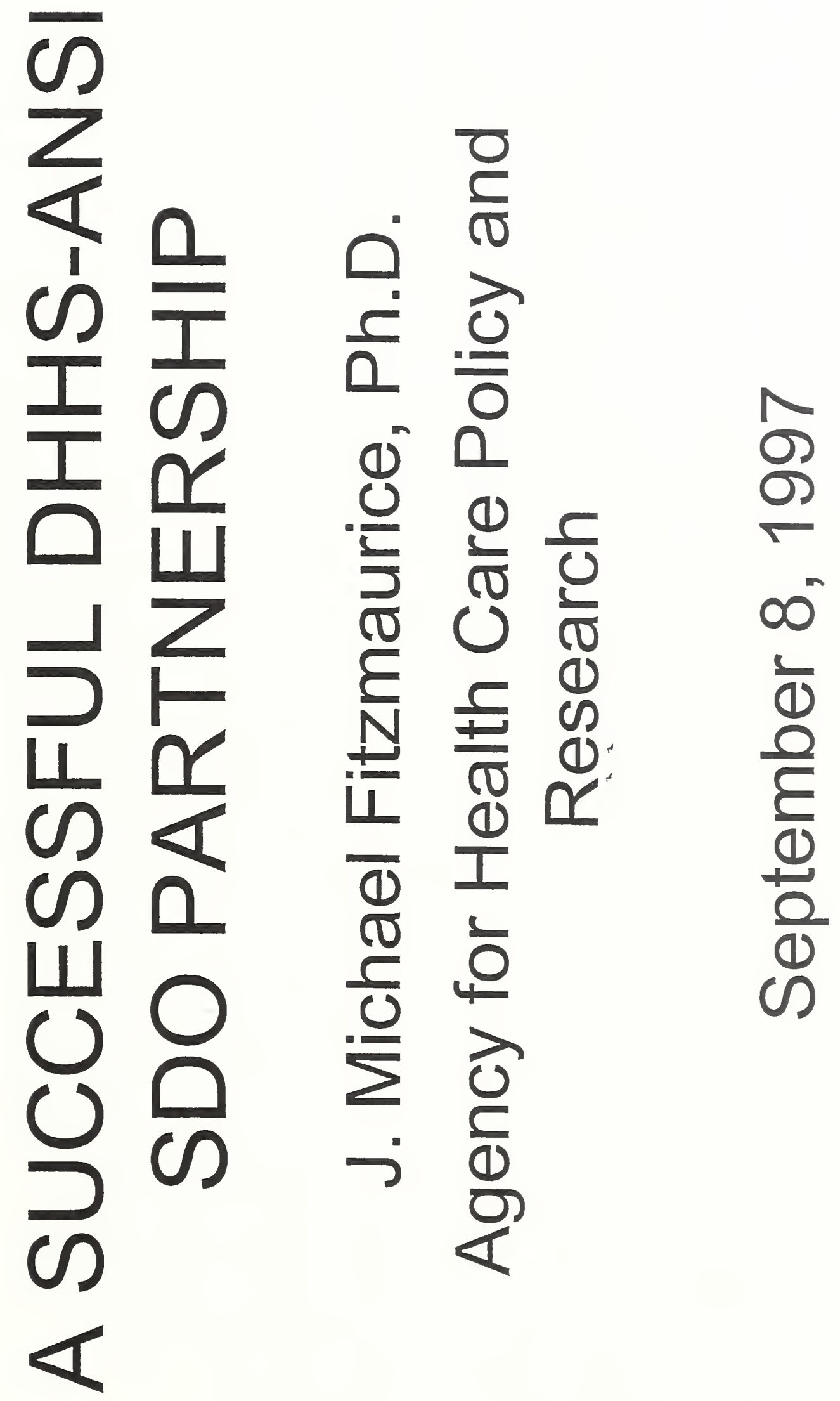




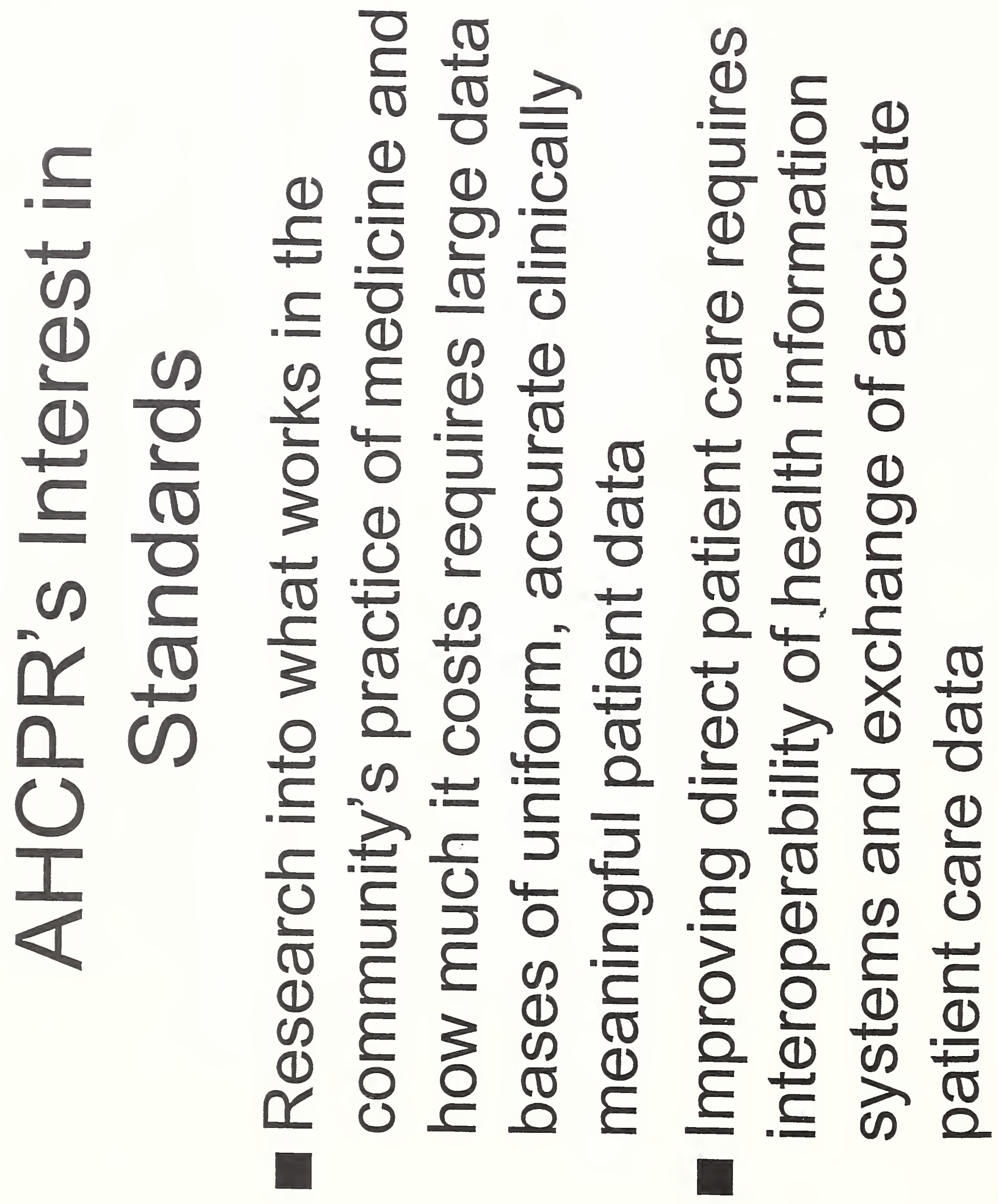




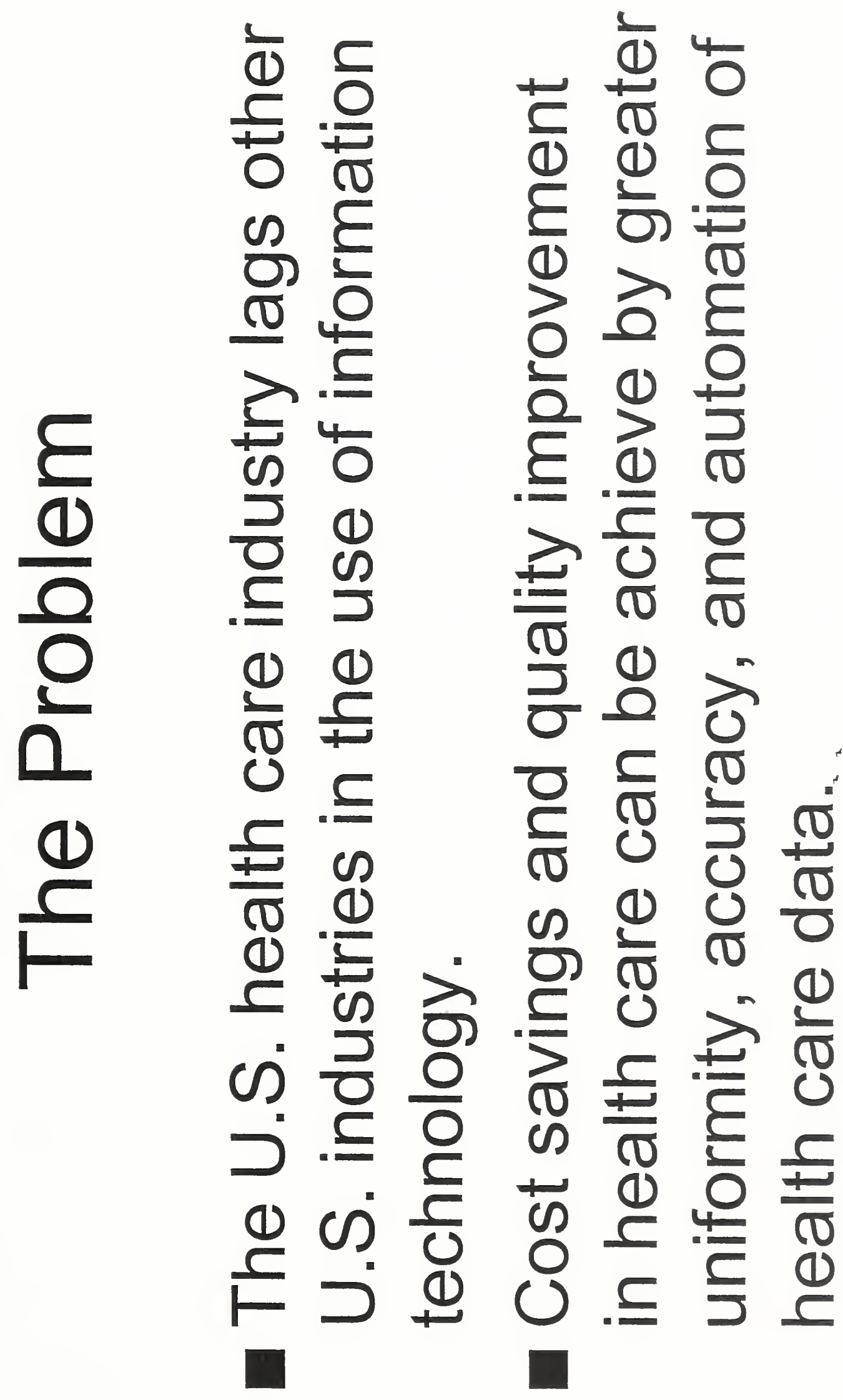




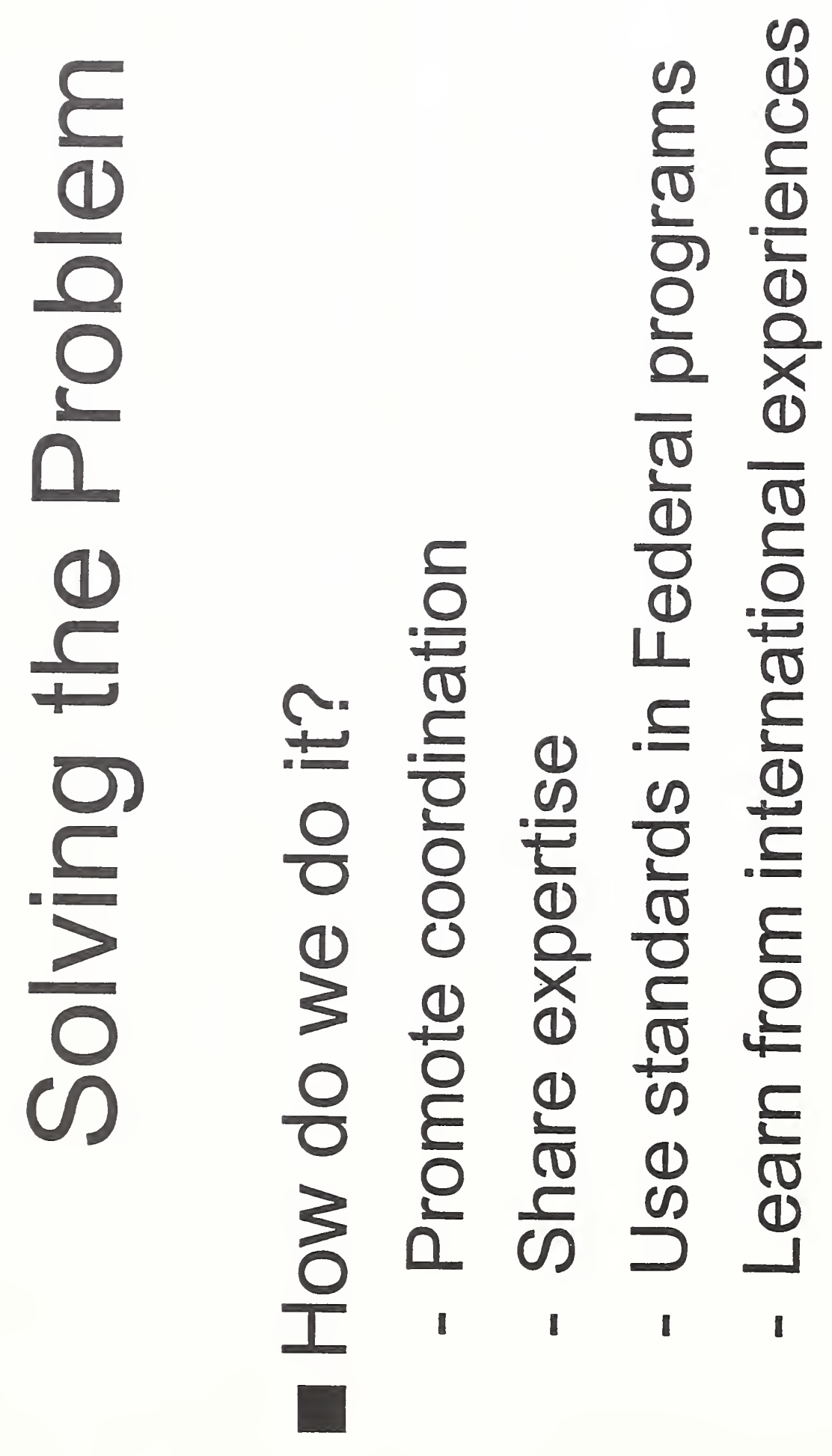




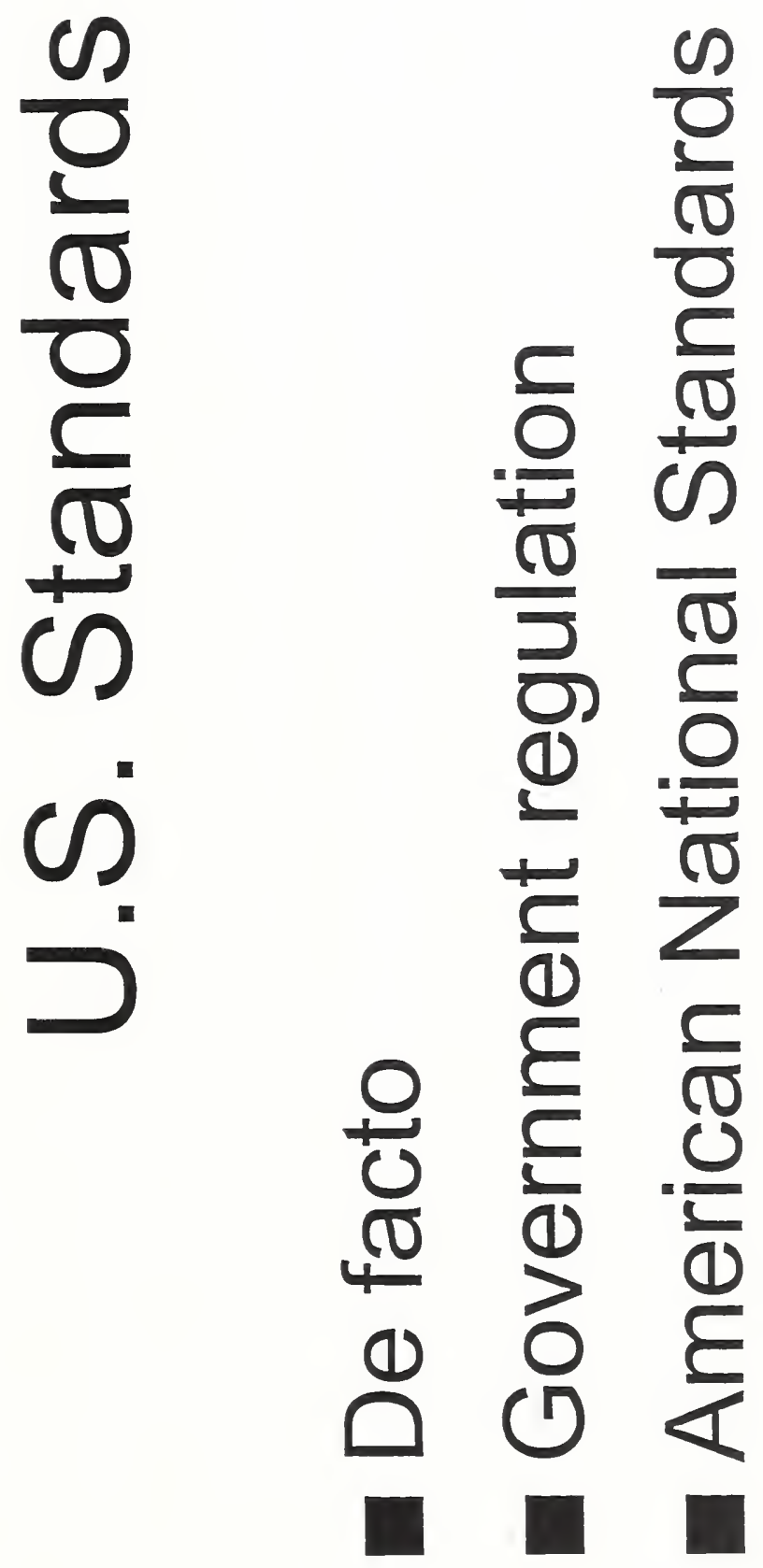




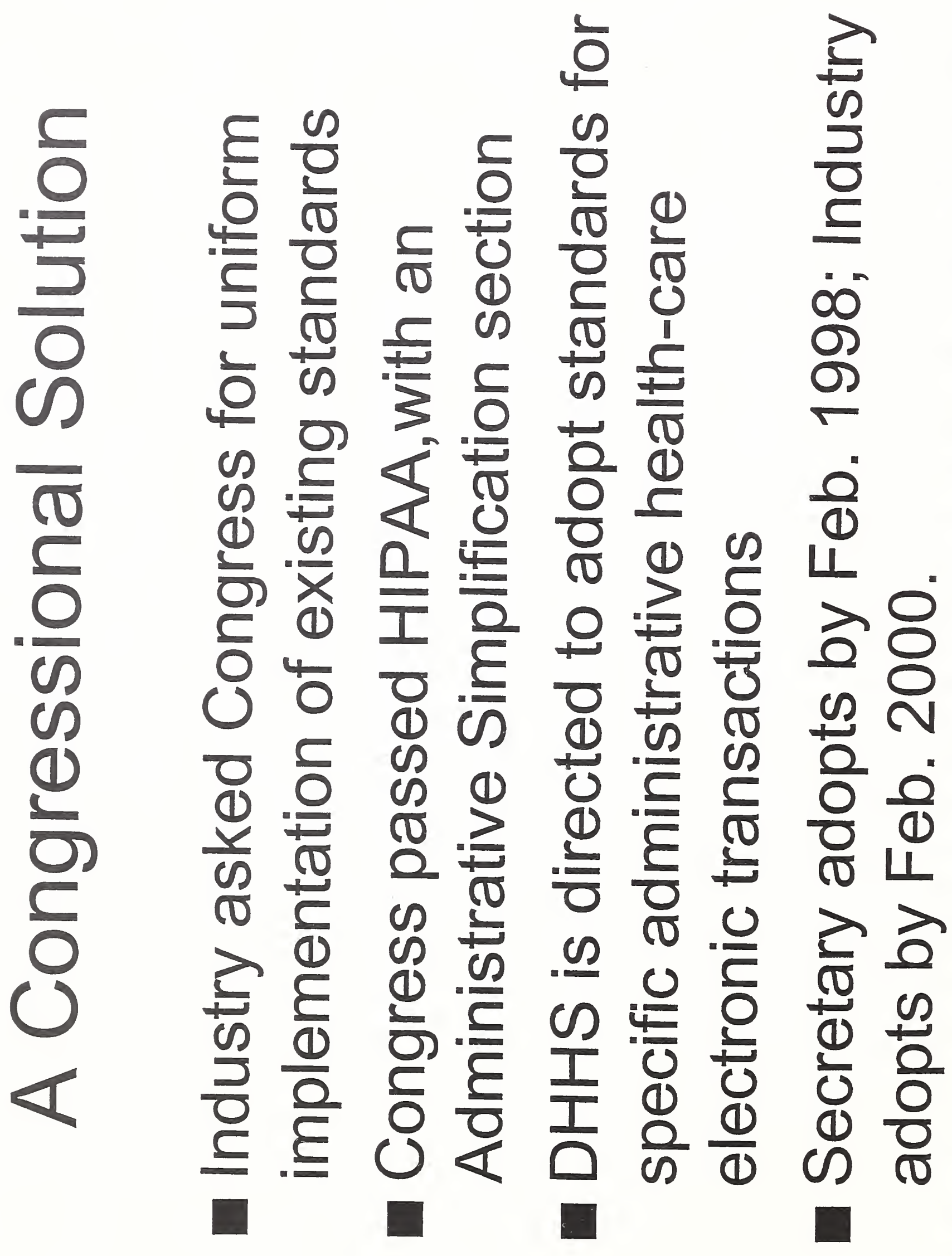

IJ 


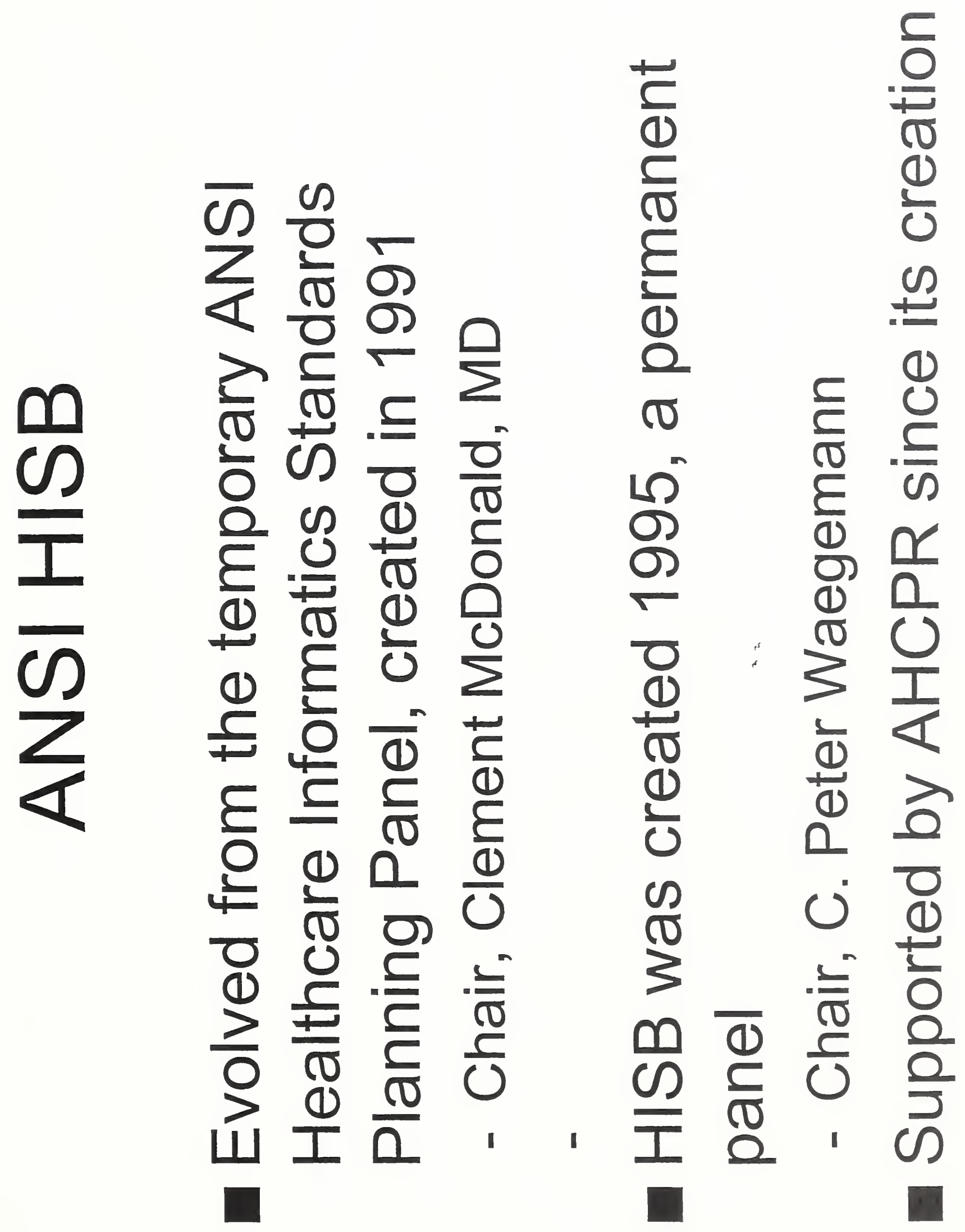


$m$

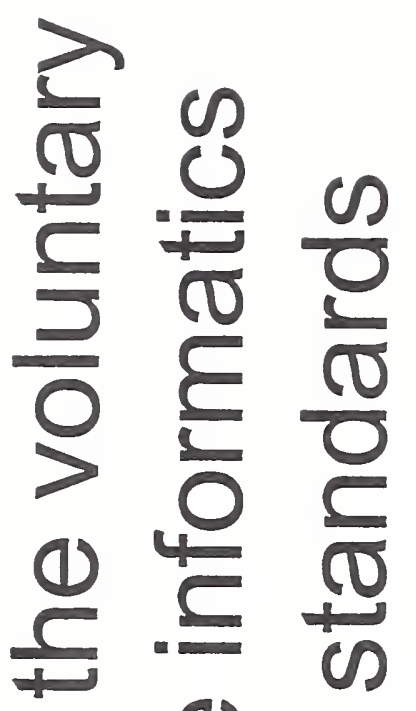

$\omega$

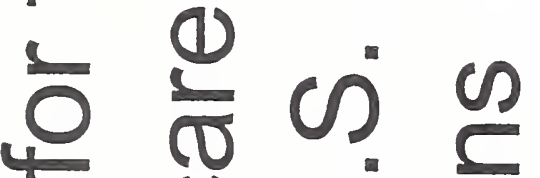

I

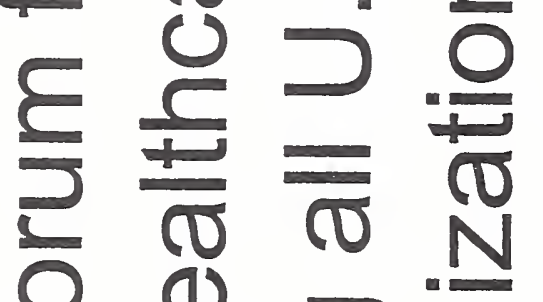

$\bar{\omega}$

눙

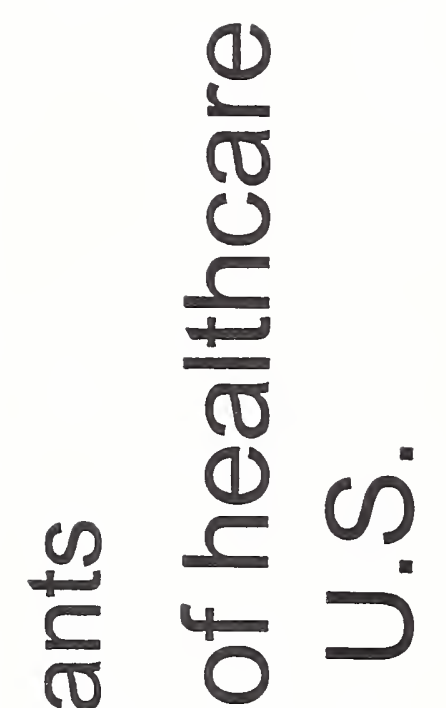

I

Les

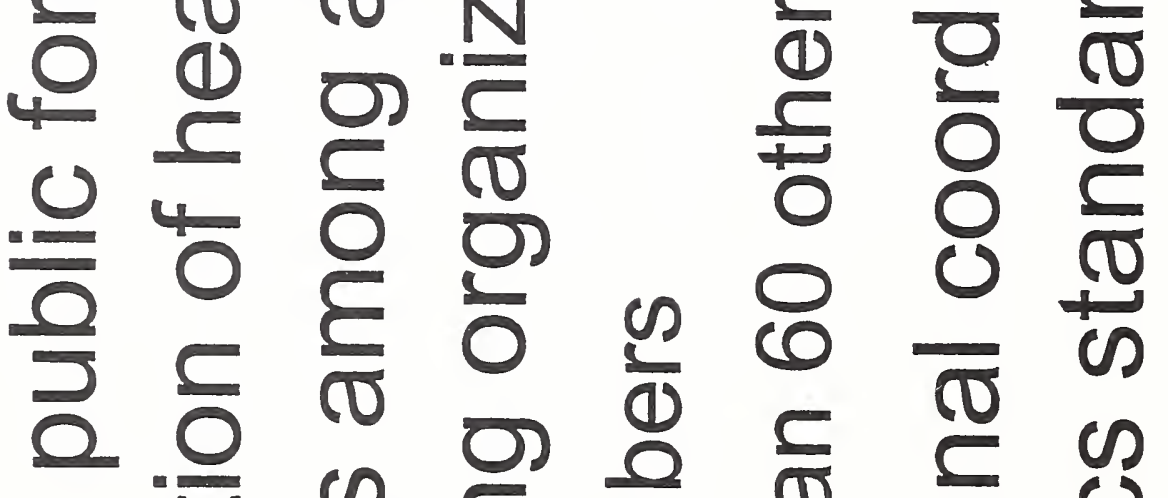

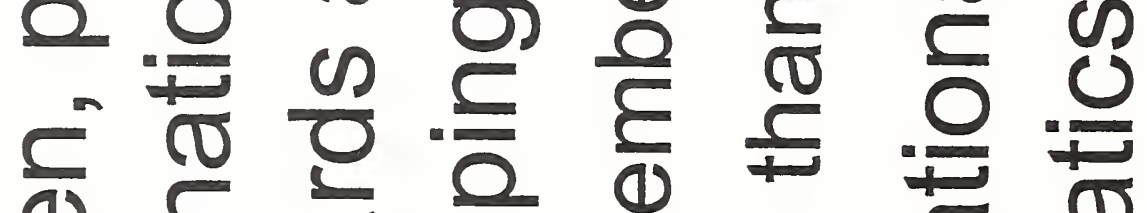

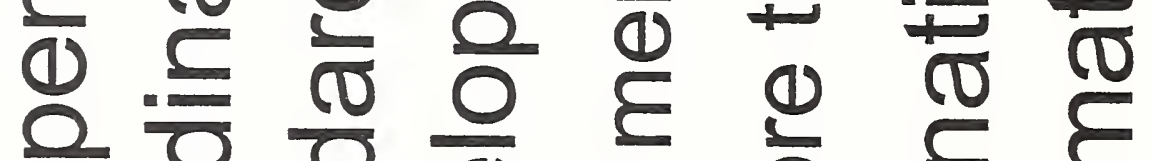

응 응 वे

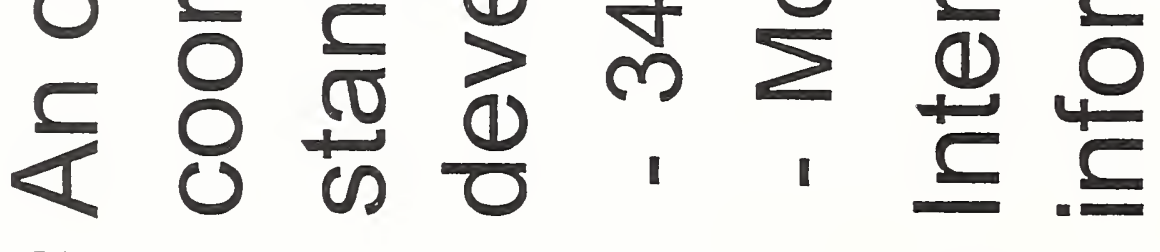

L.

is 


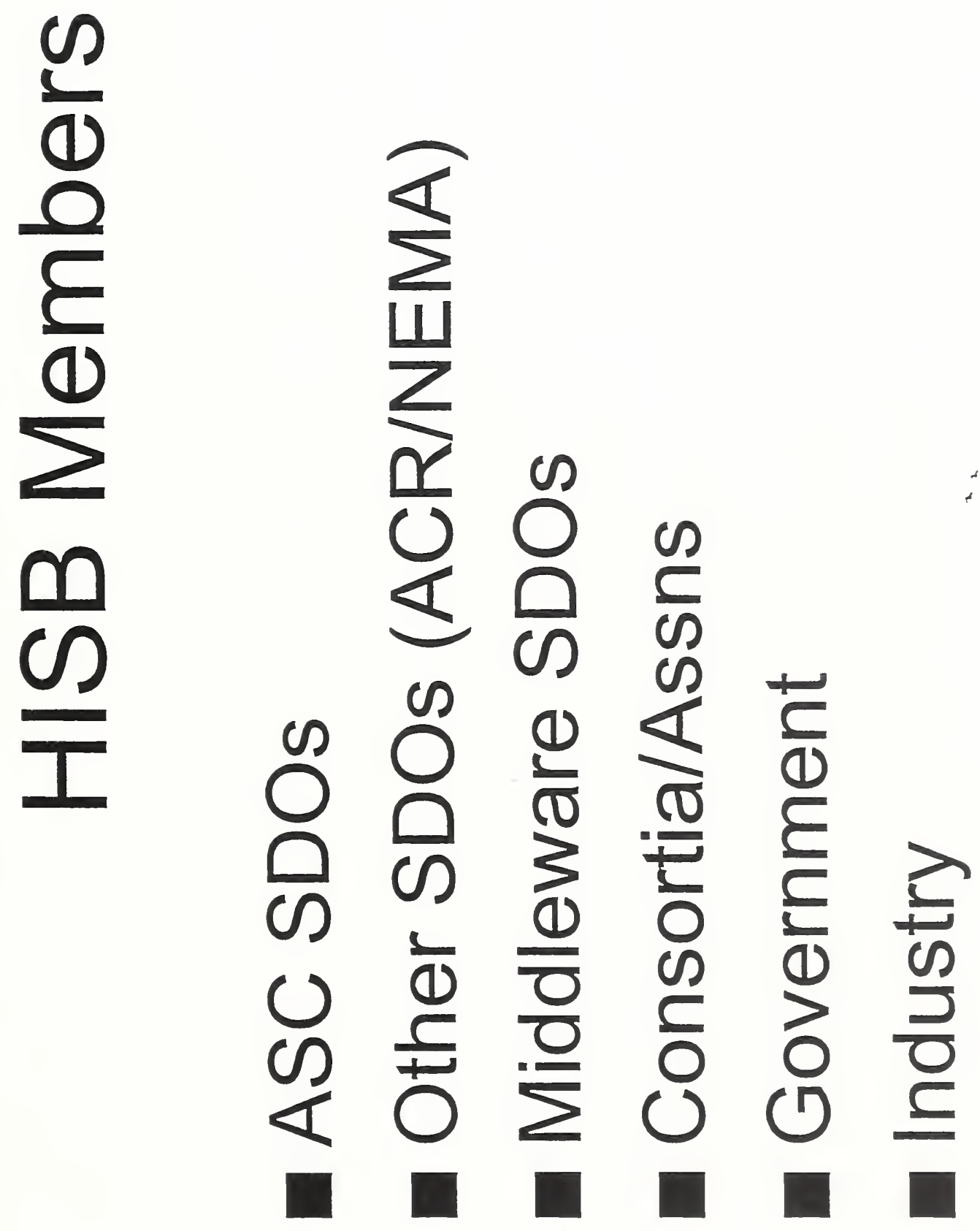



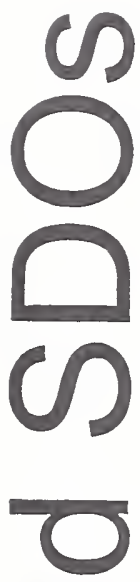

(1)

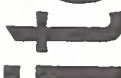

훙

(1)

3

0

4
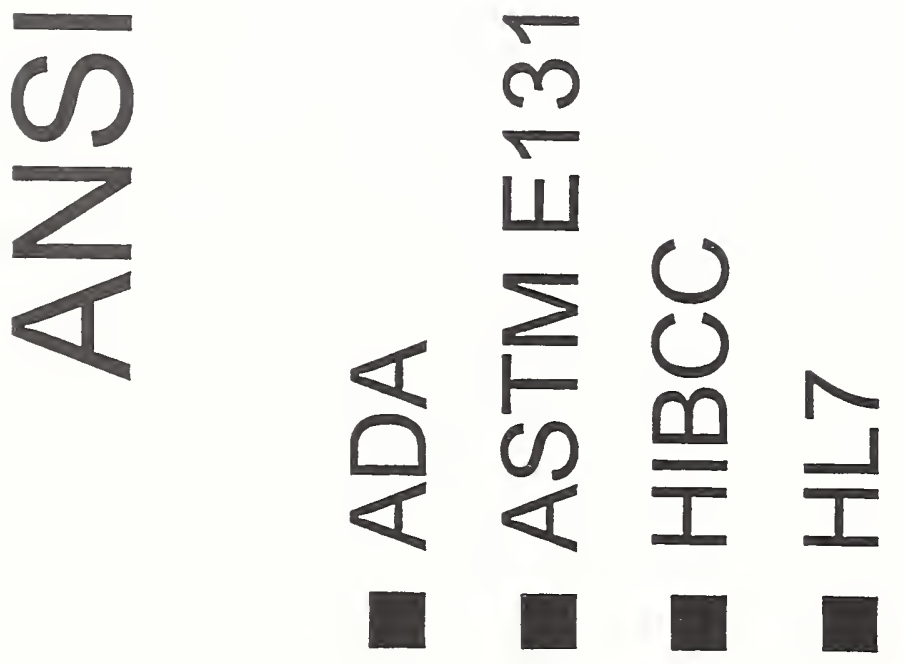


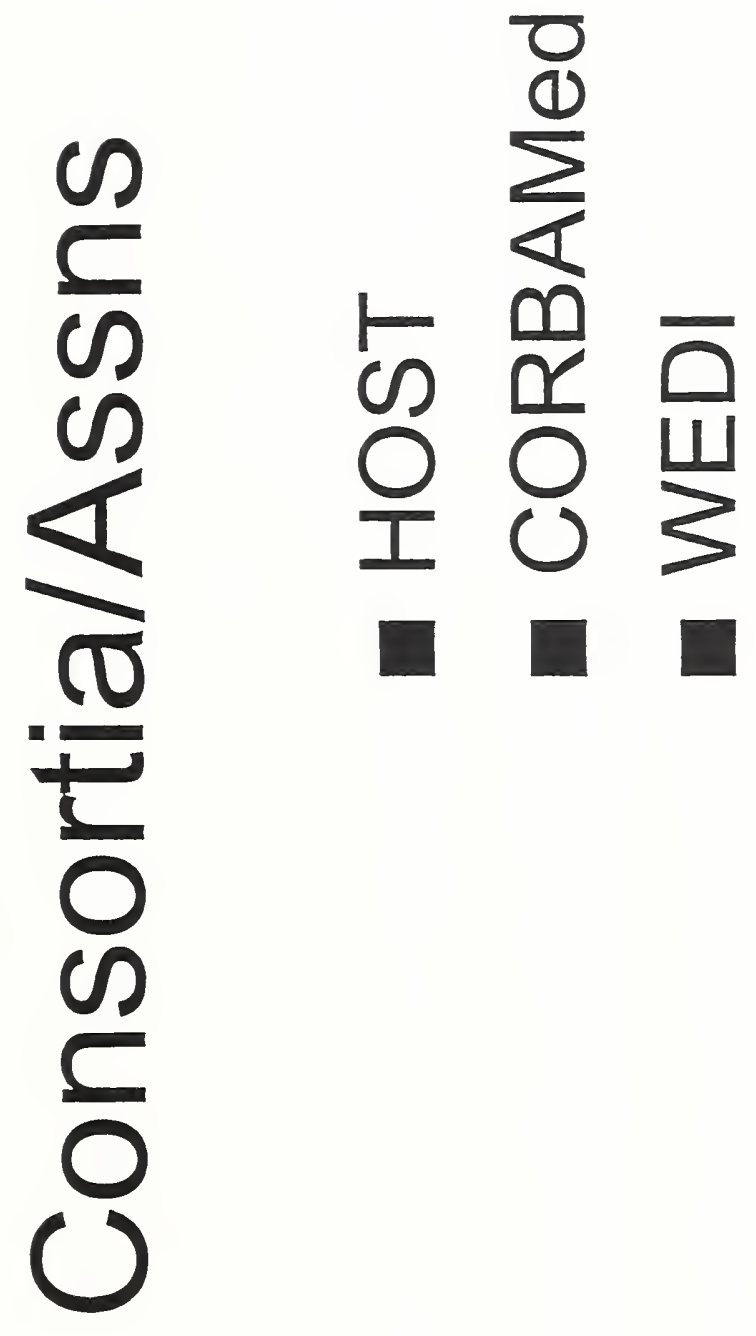

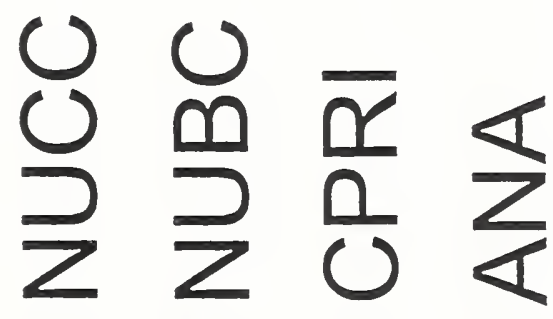

$$
\begin{aligned}
& \text { - घ }
\end{aligned}
$$




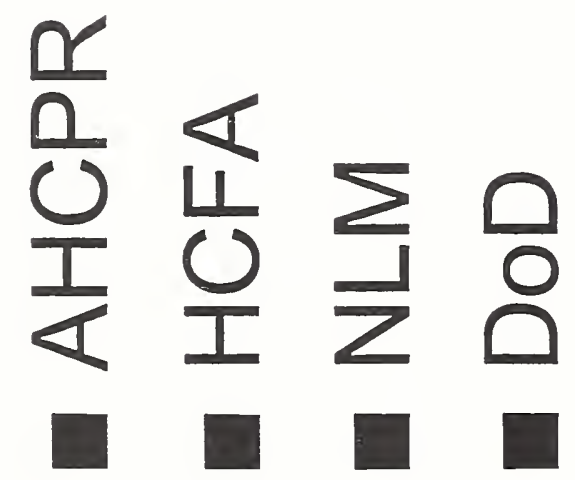




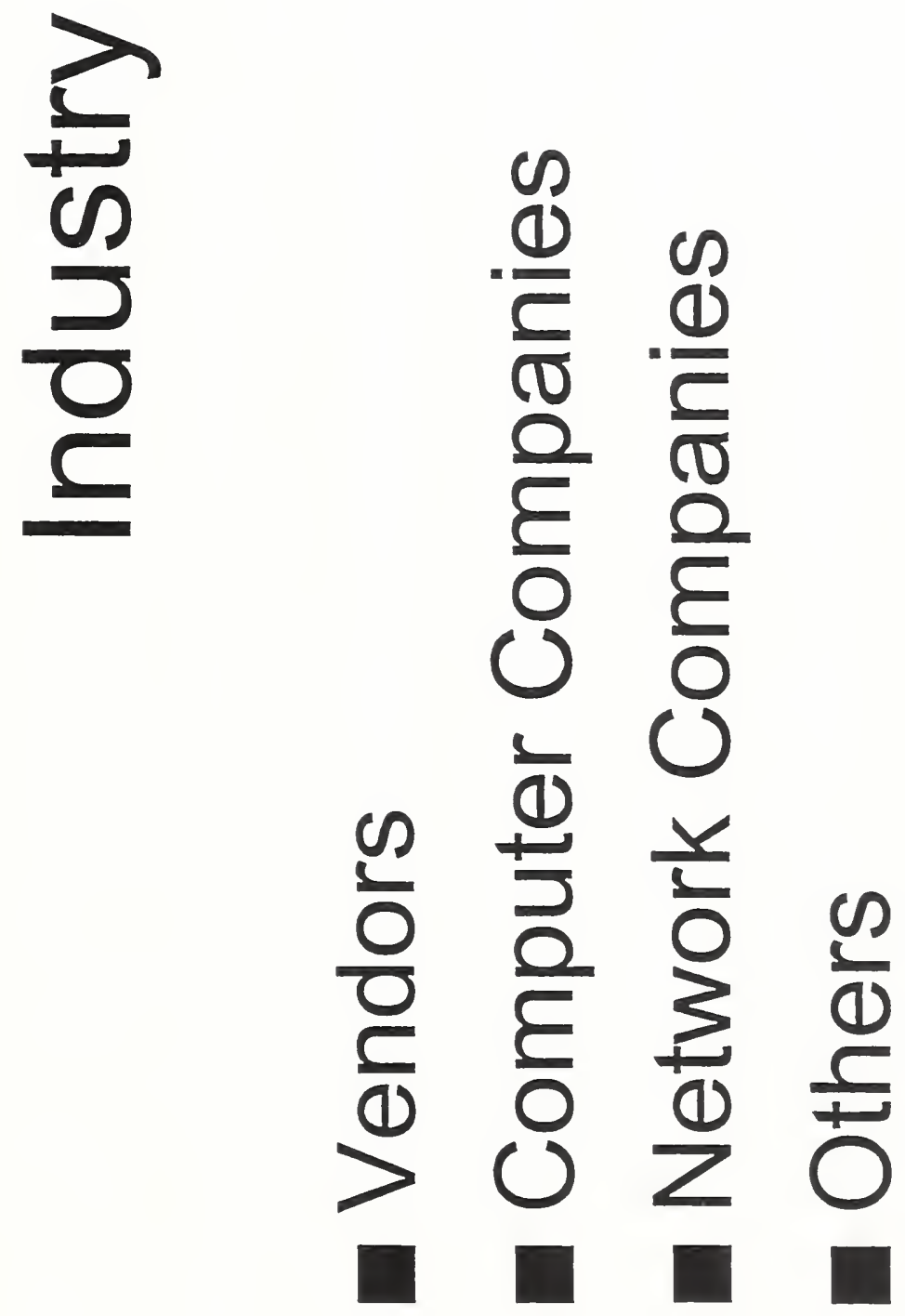


$m$

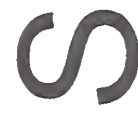

$\stackrel{\infty}{+\infty}$

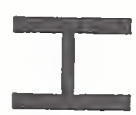

4

$=\stackrel{0}{0}$

1

$\because 0$

co $\frac{E}{0}$

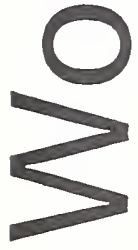

(1)

$-\square$

(o)

$0 \square$

0

$E$

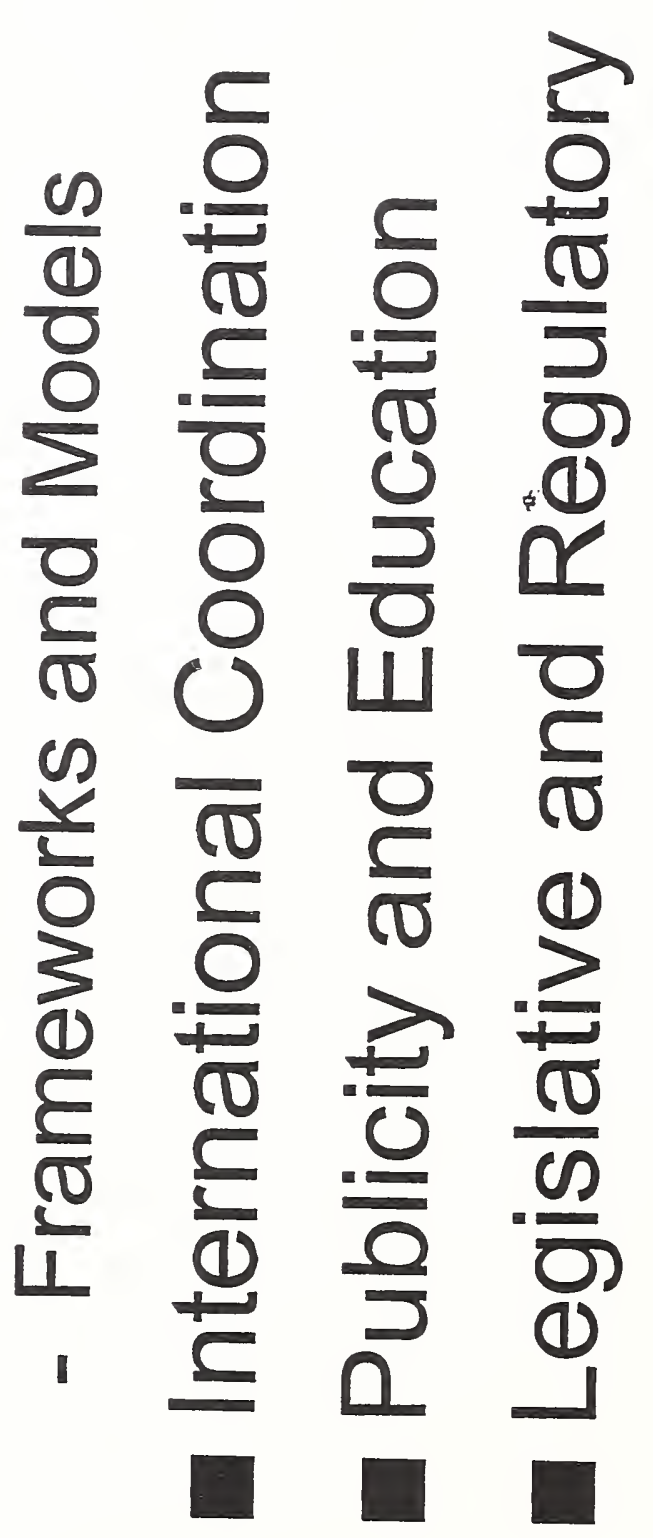

a

당

(1) $>\infty$

$\vdash$

I

I 


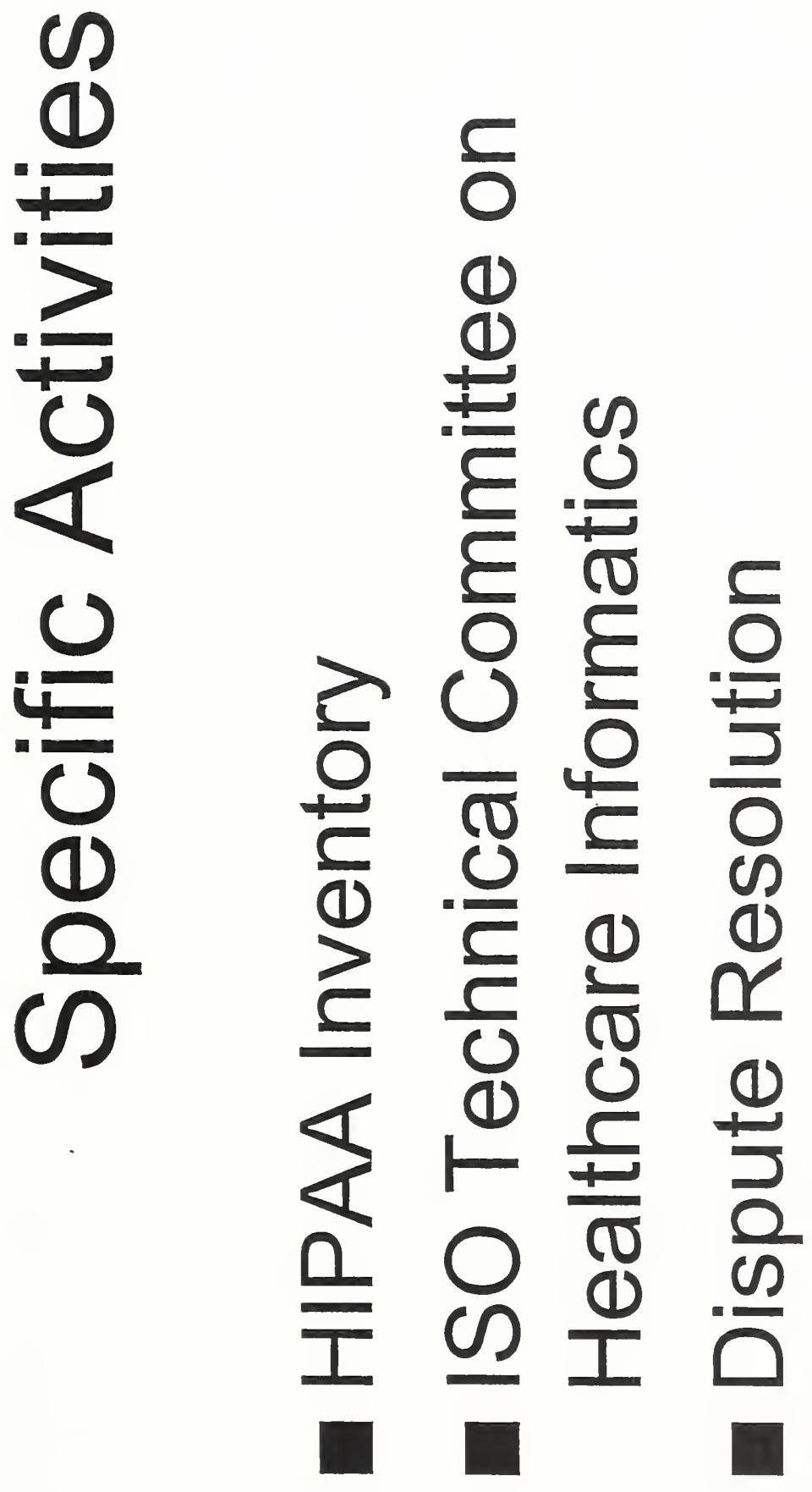



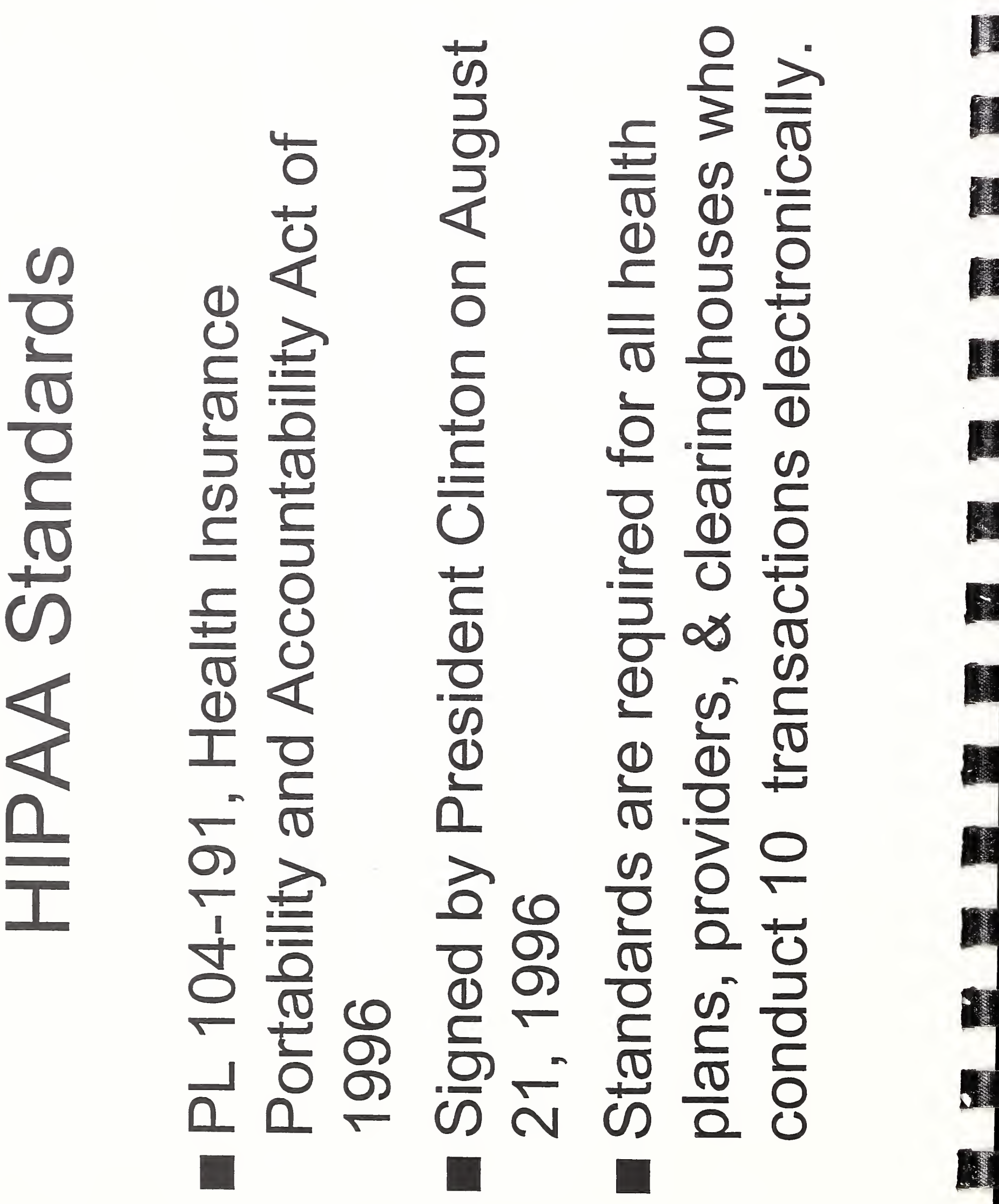


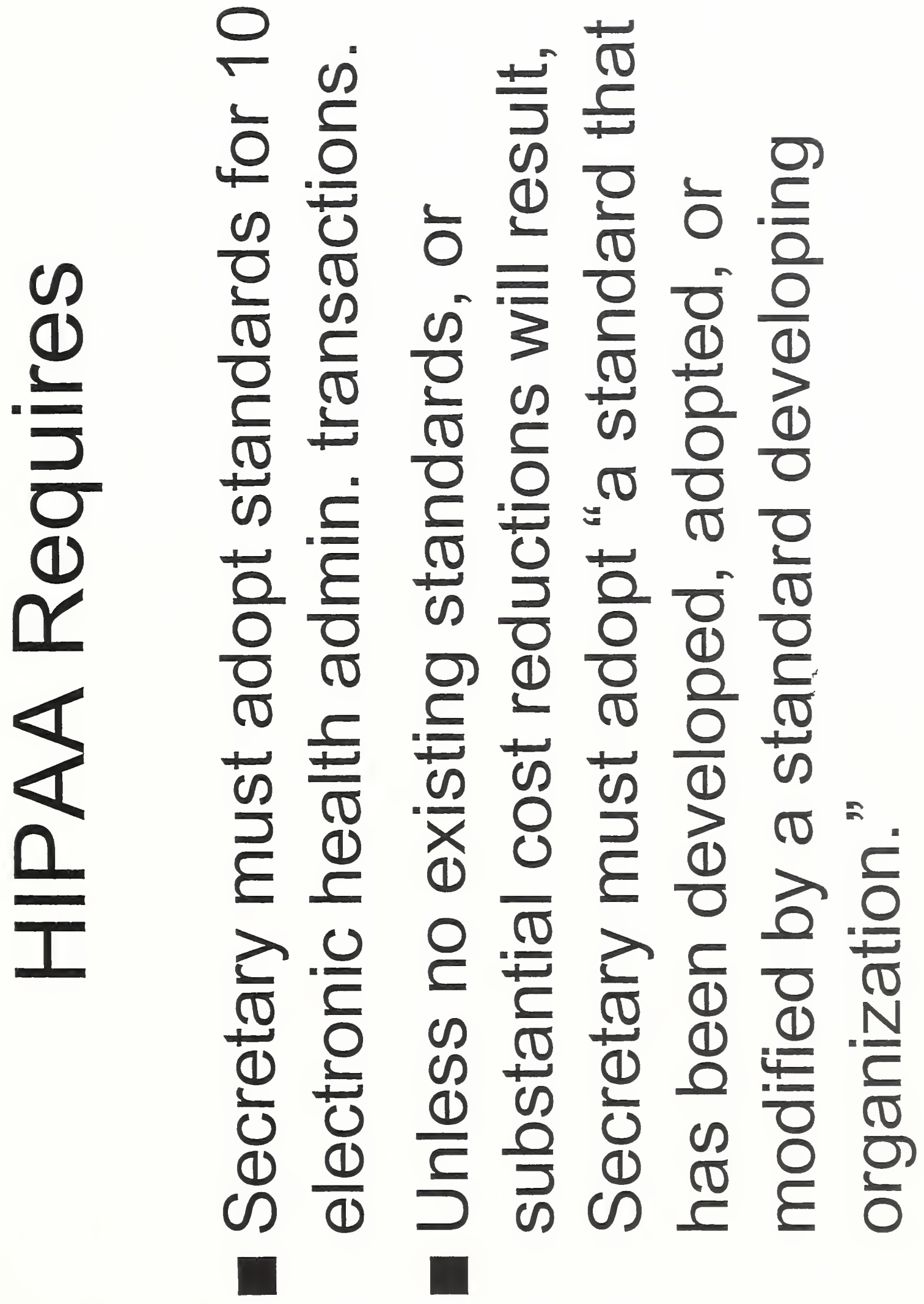




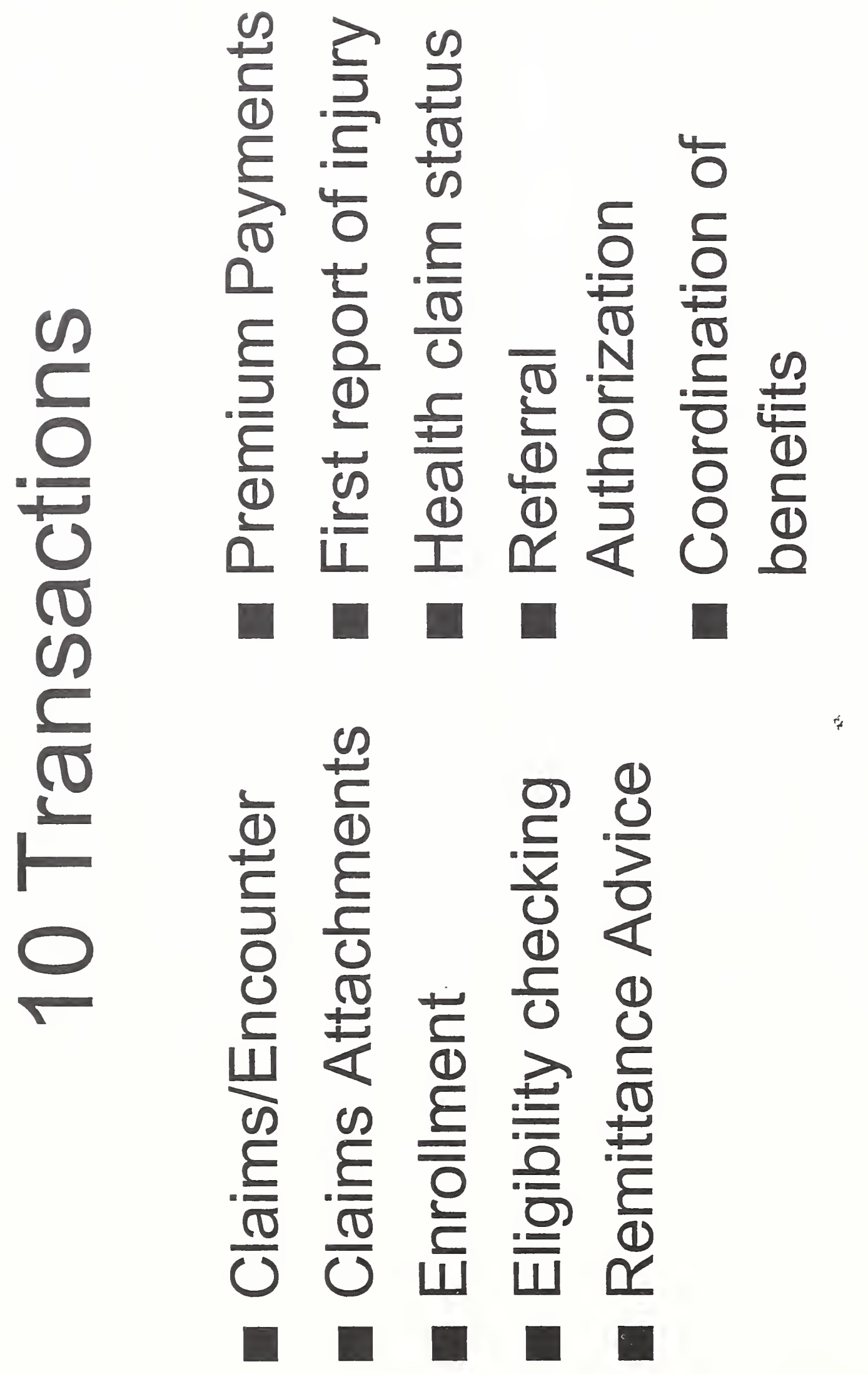




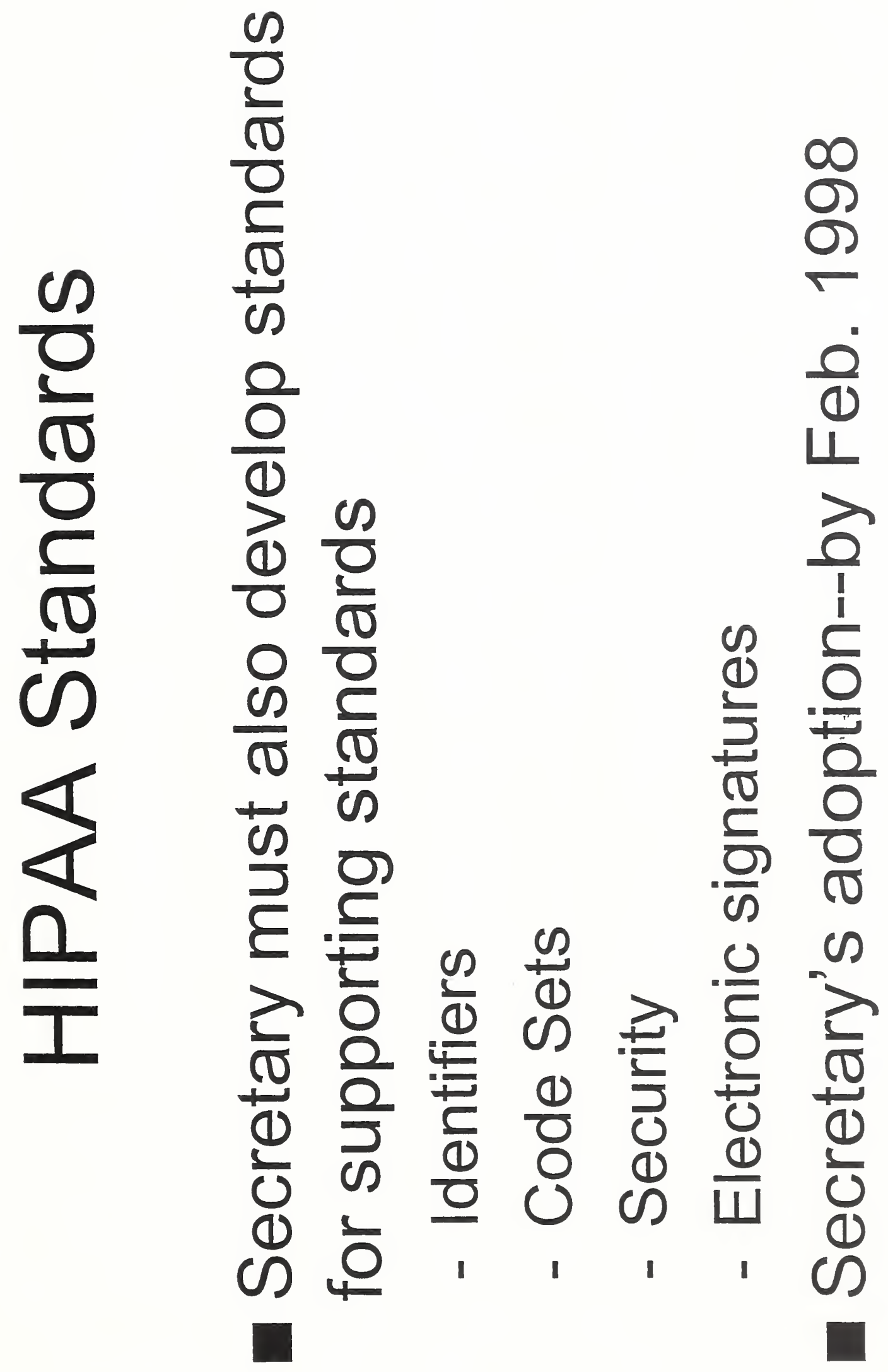



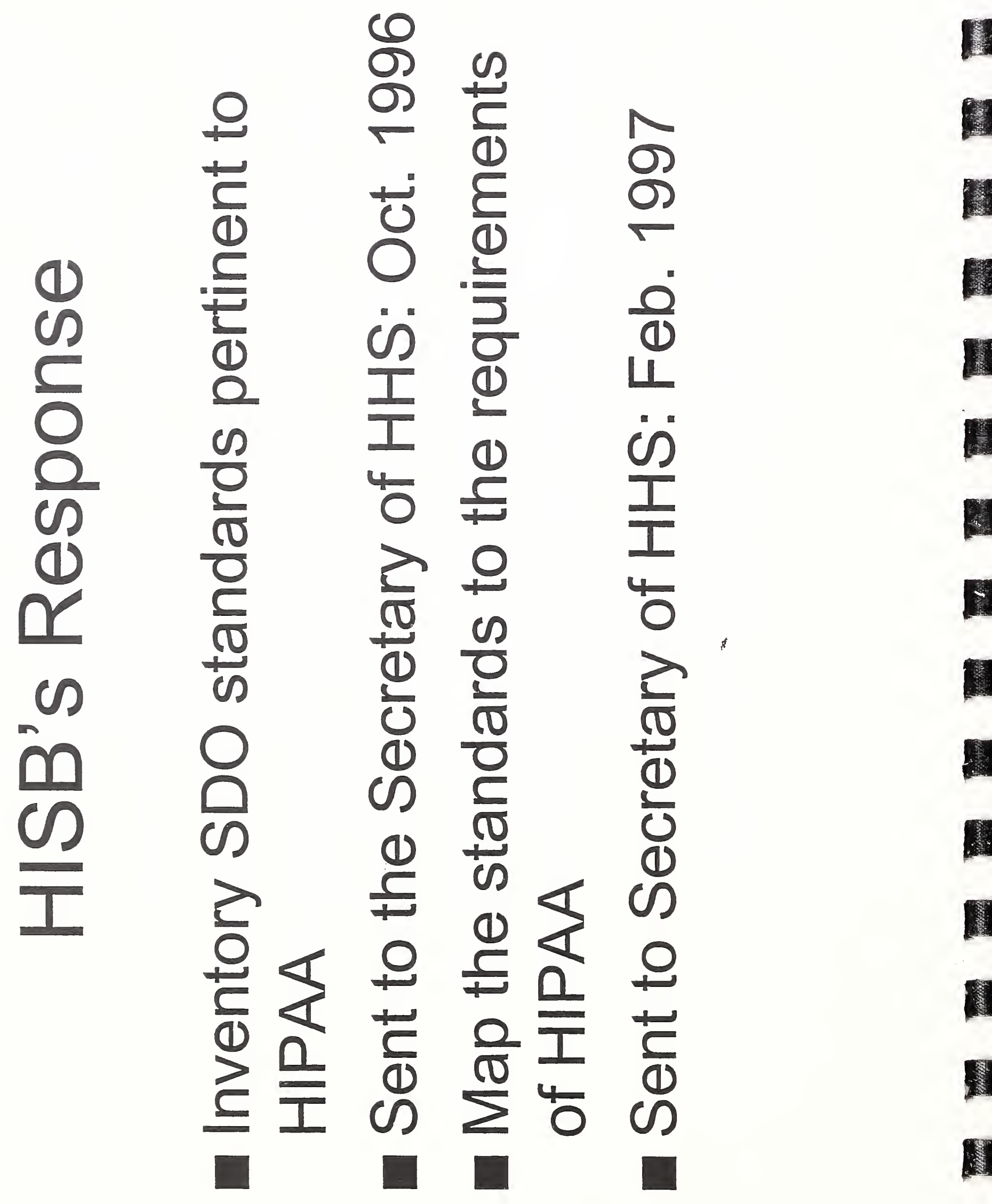


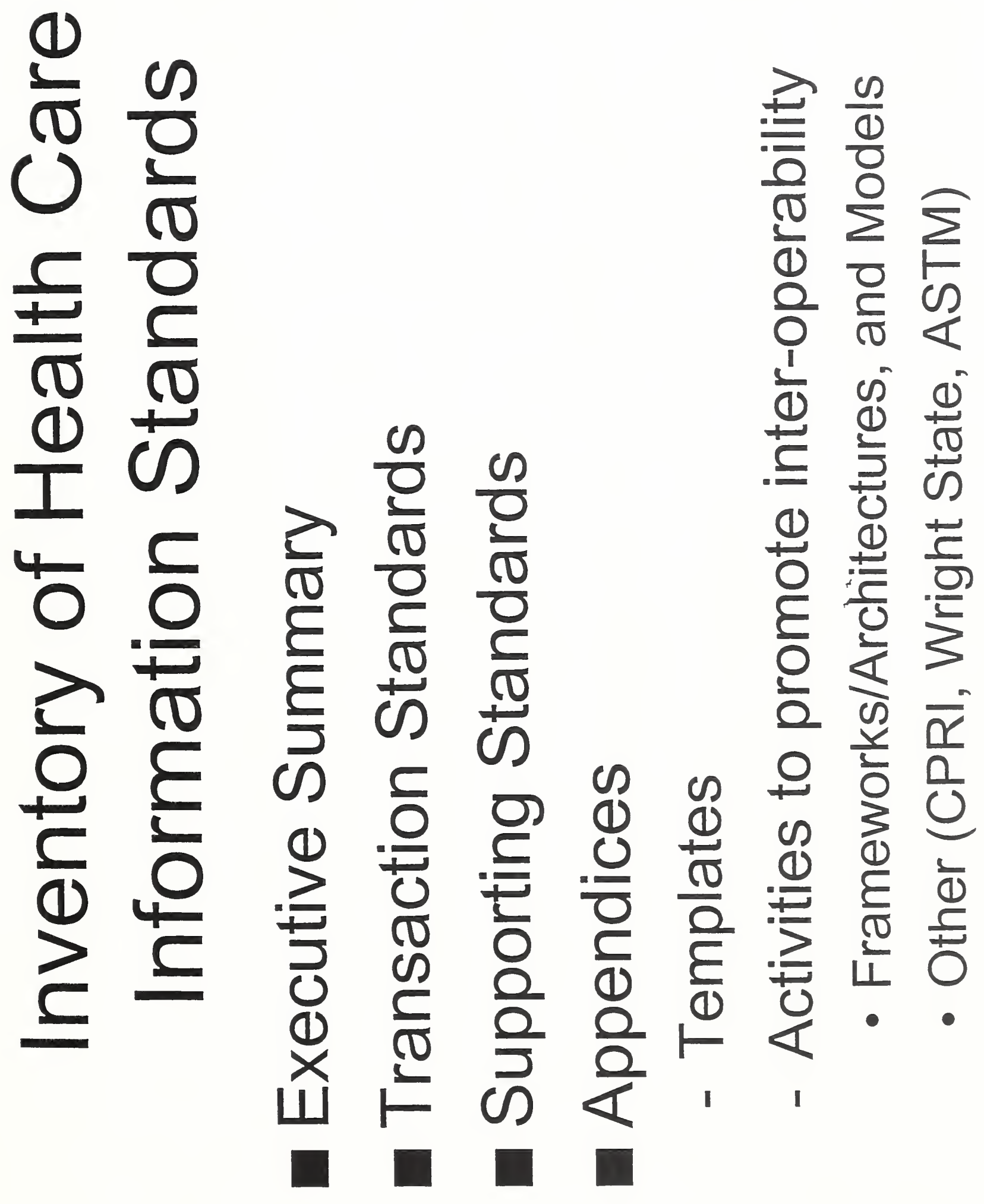




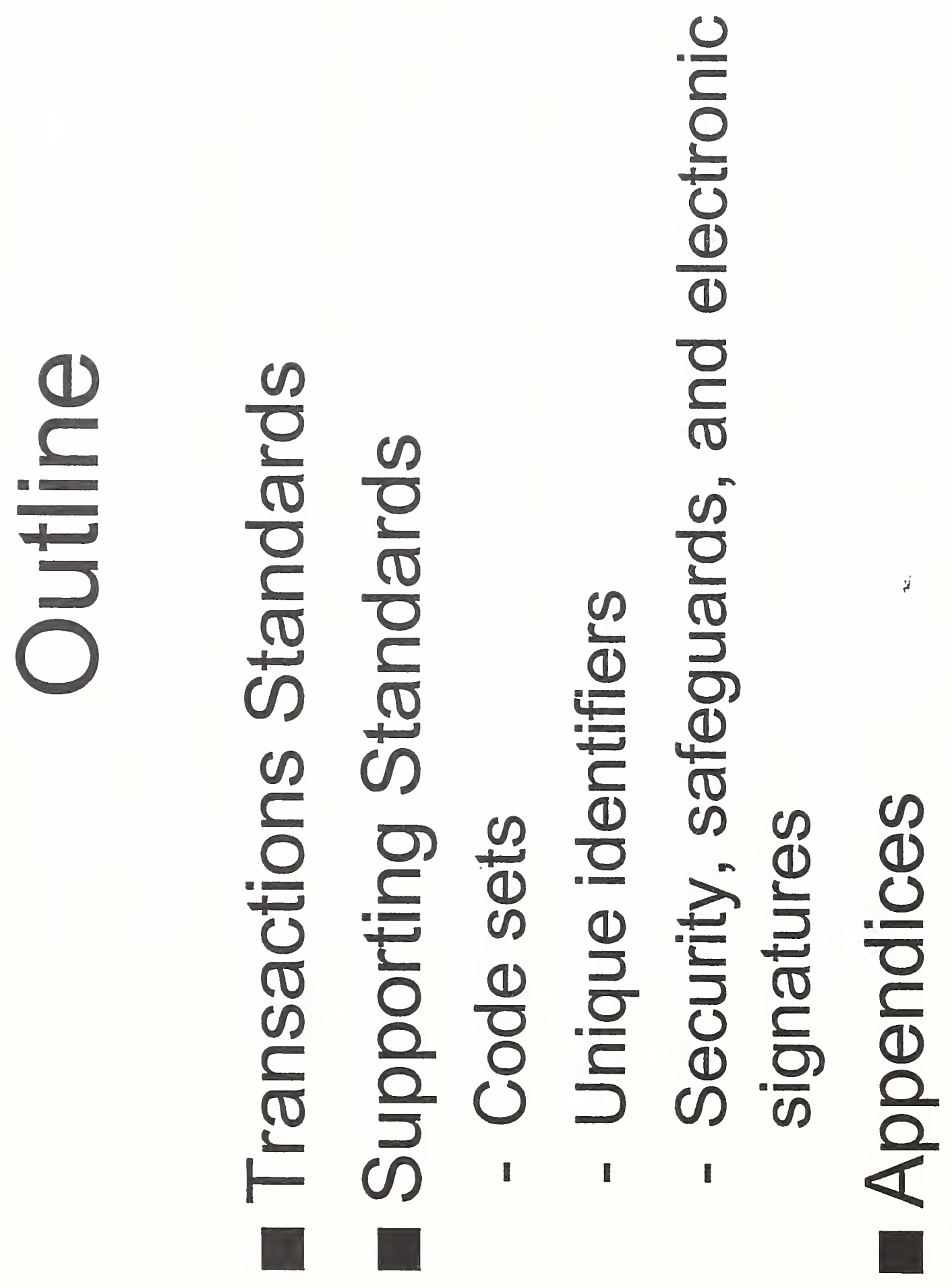




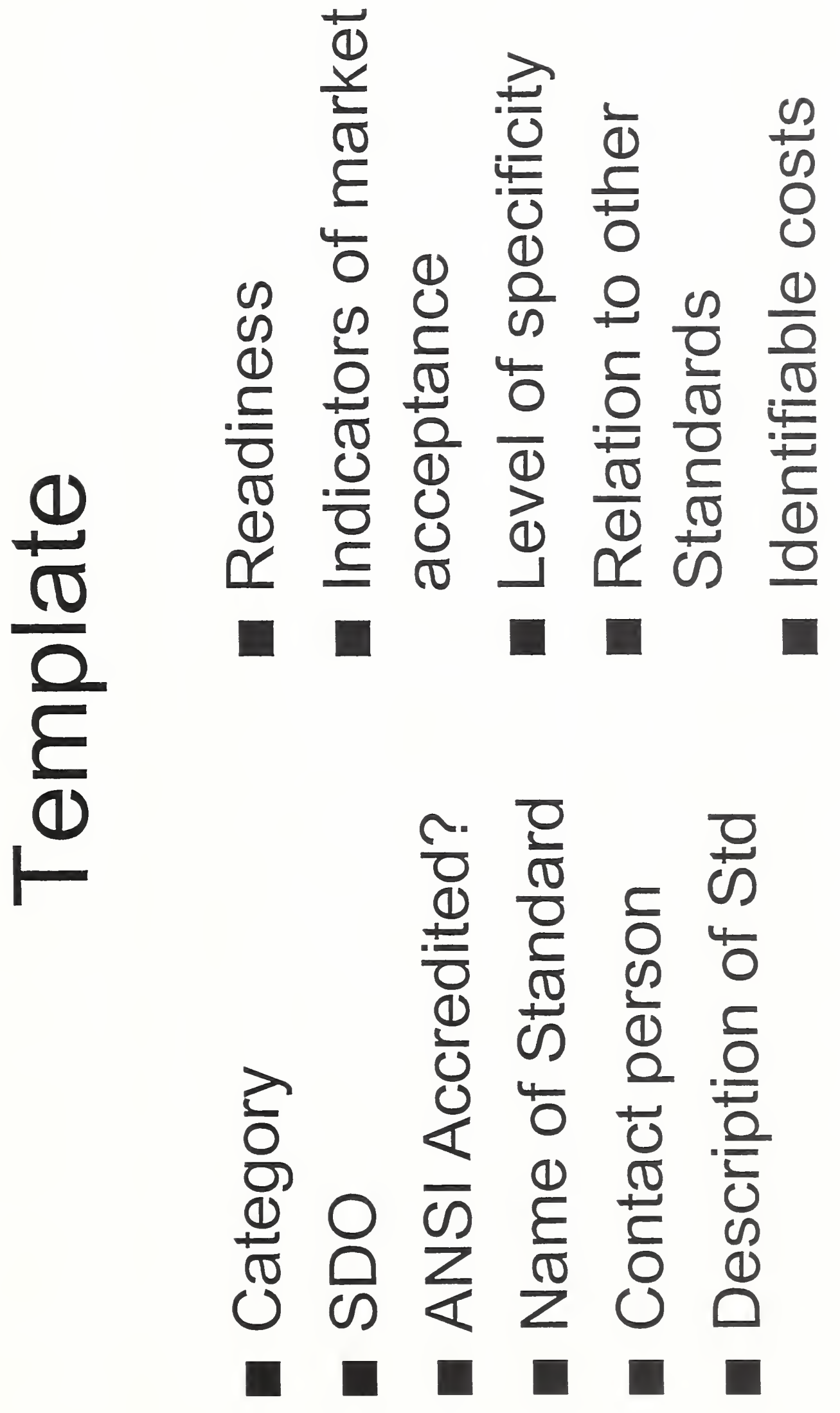




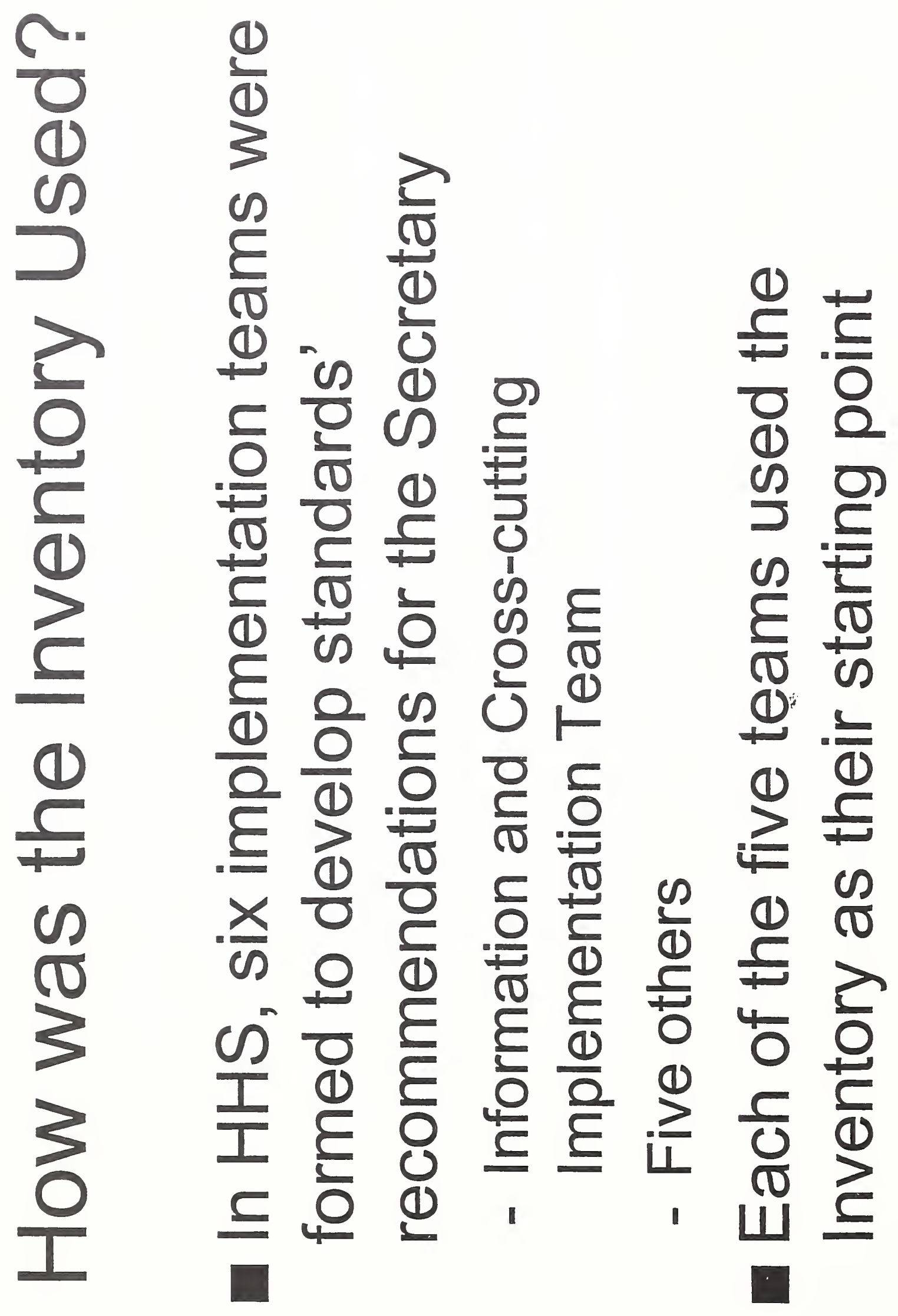




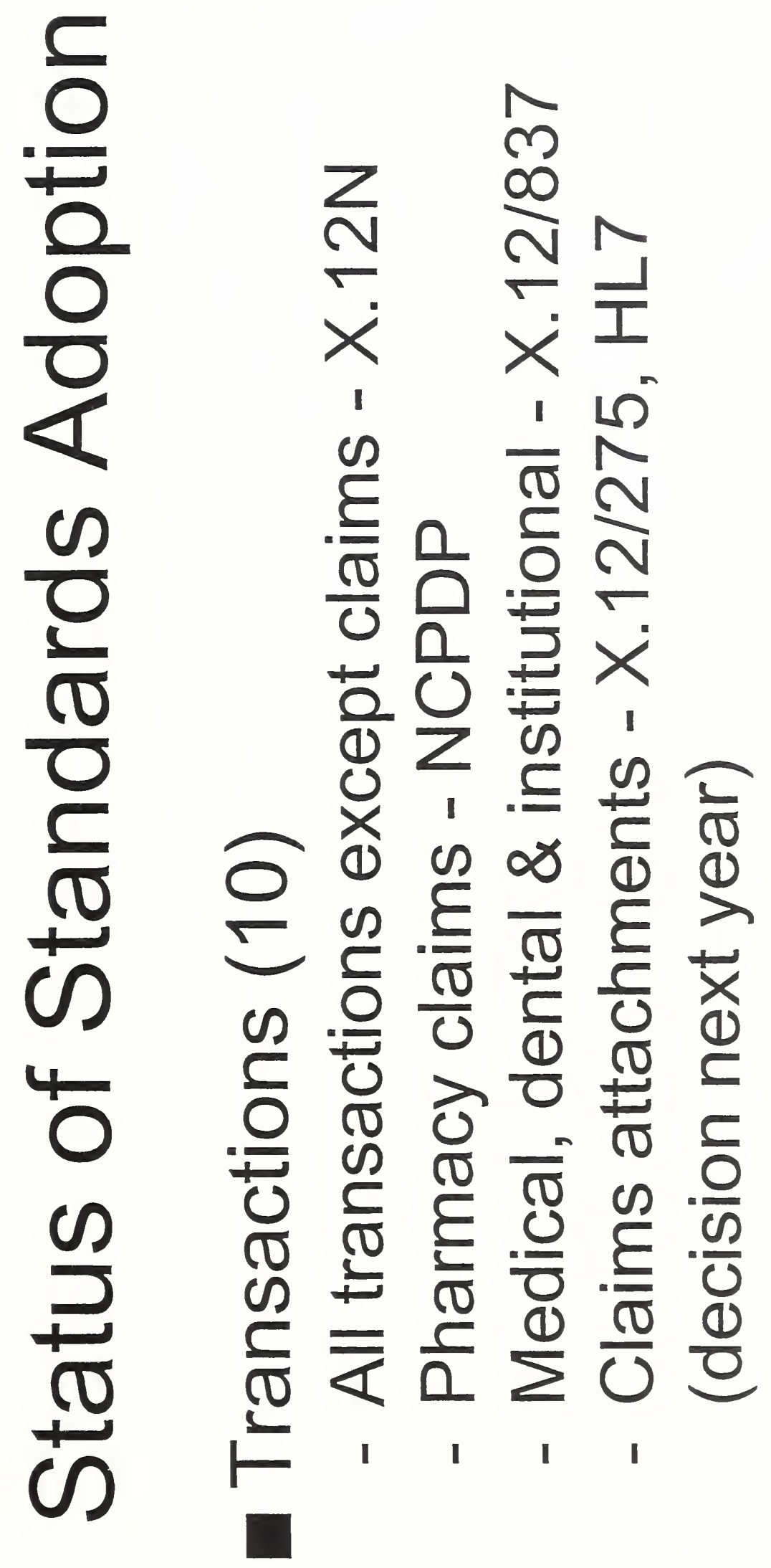




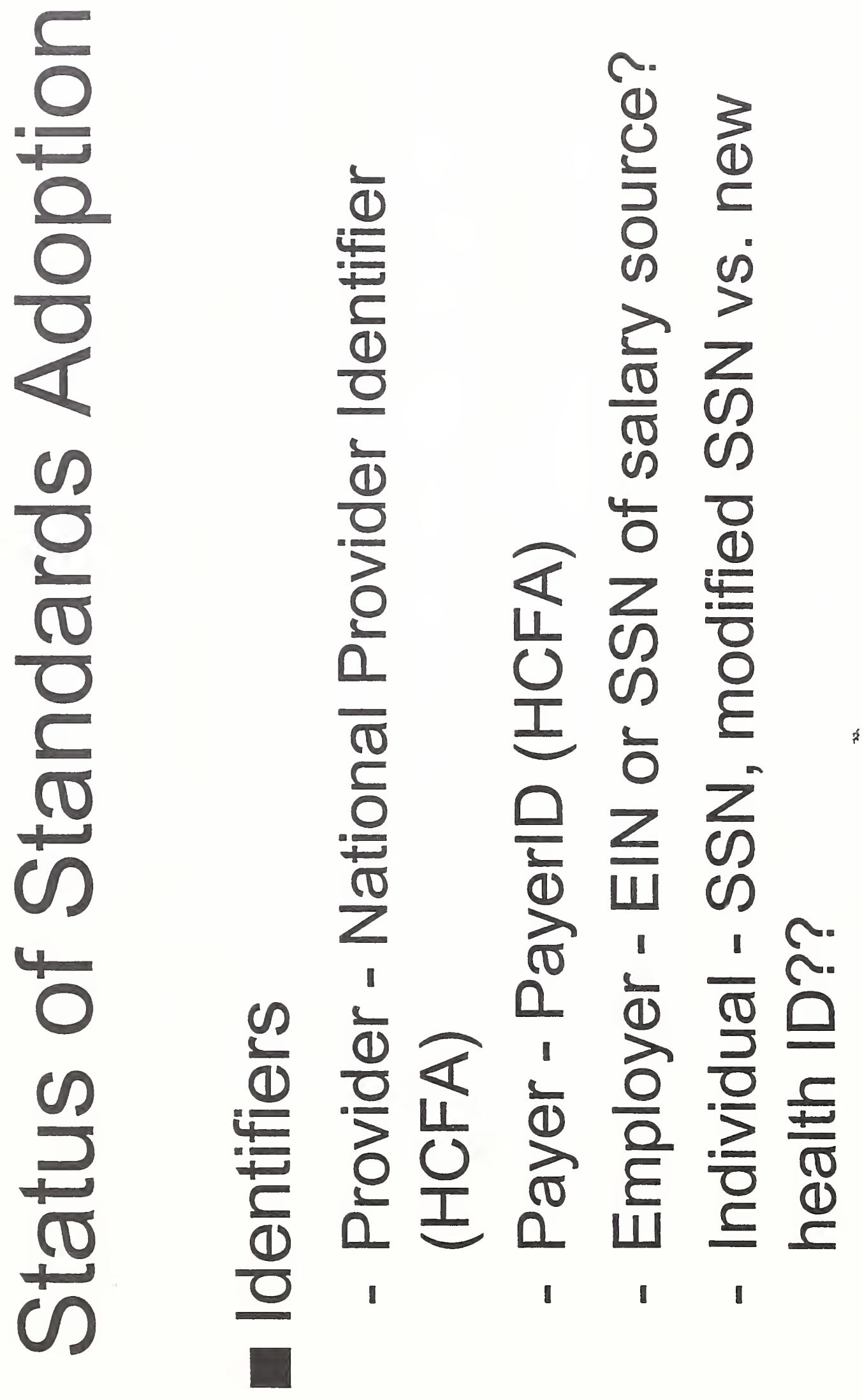




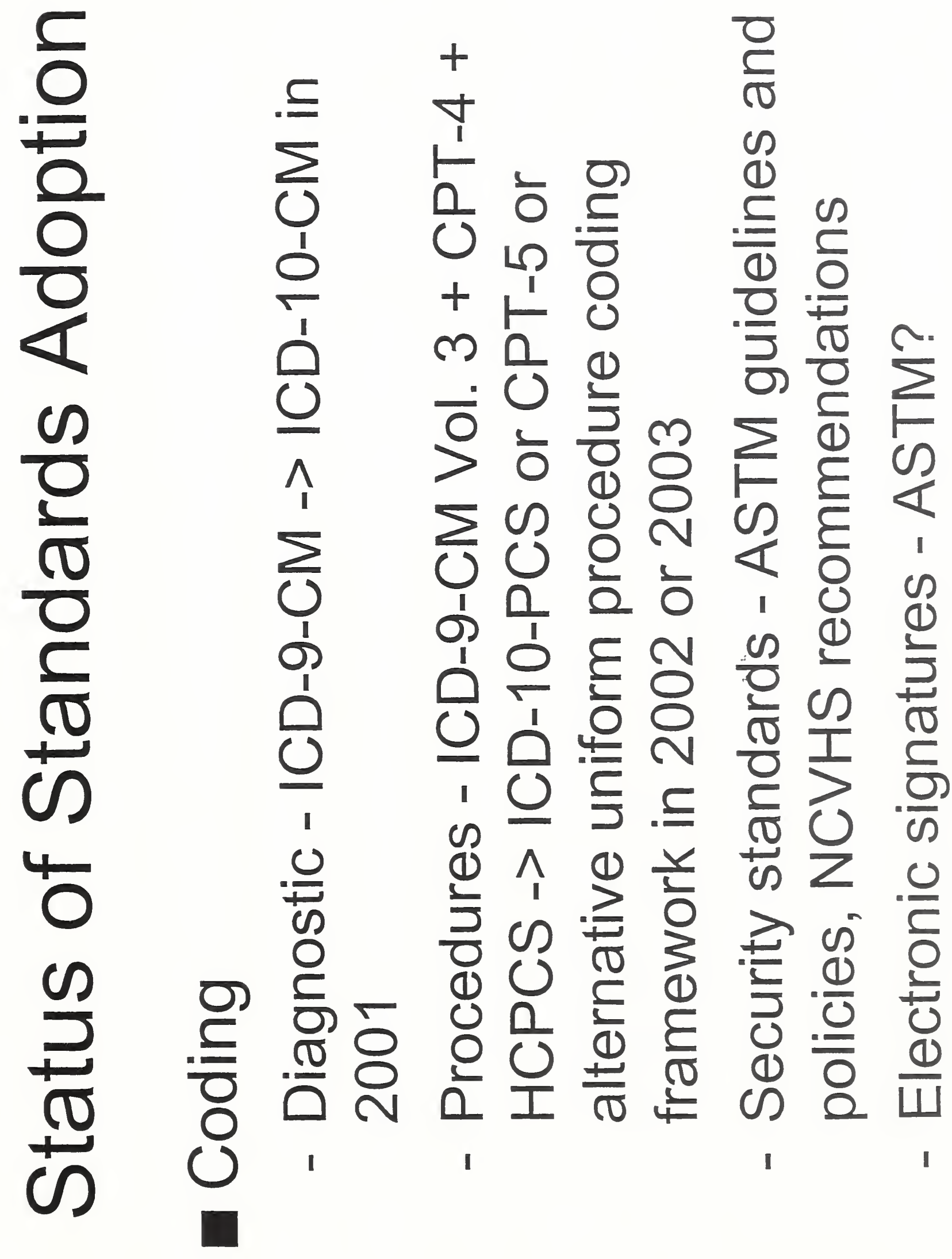




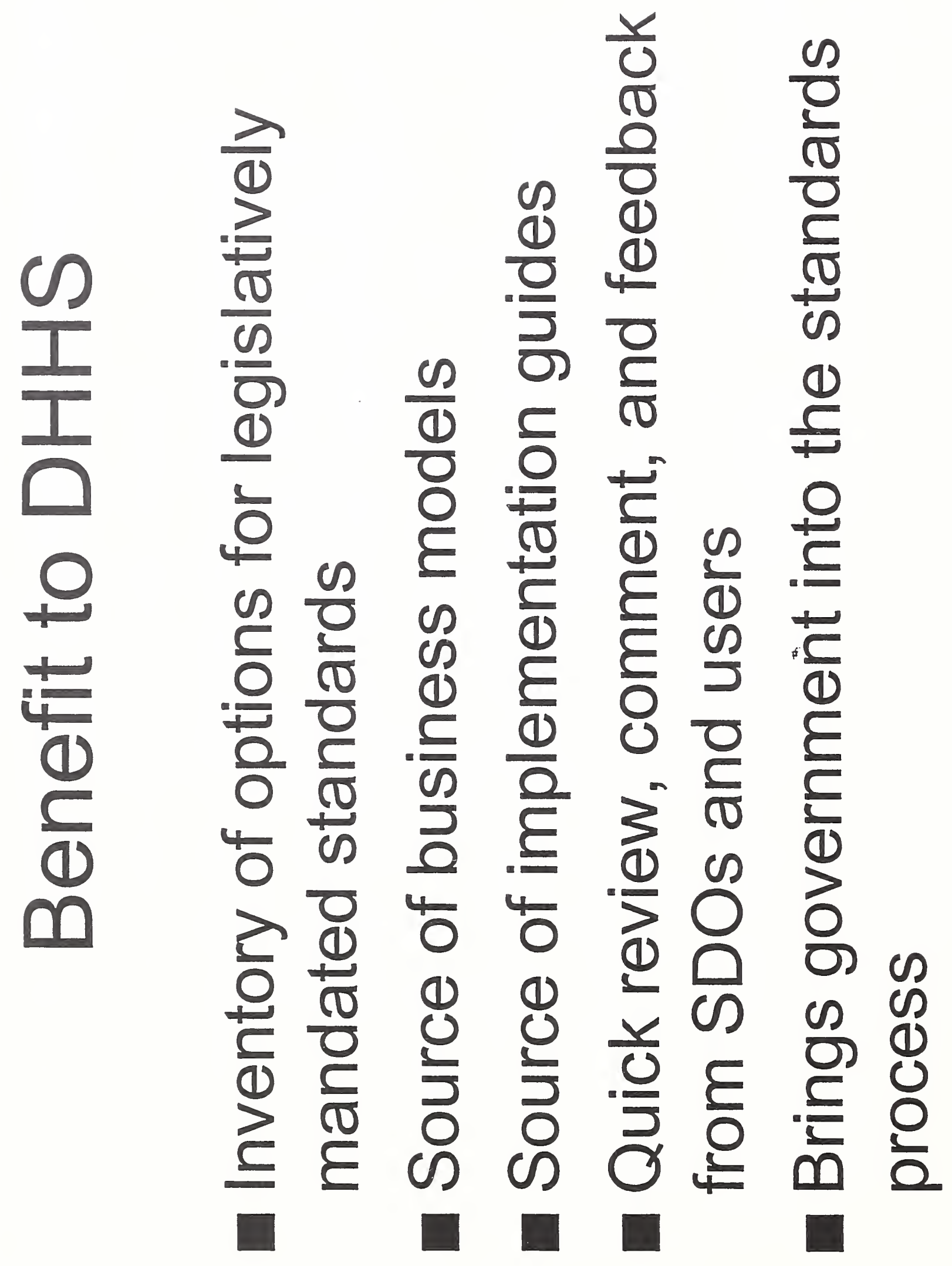




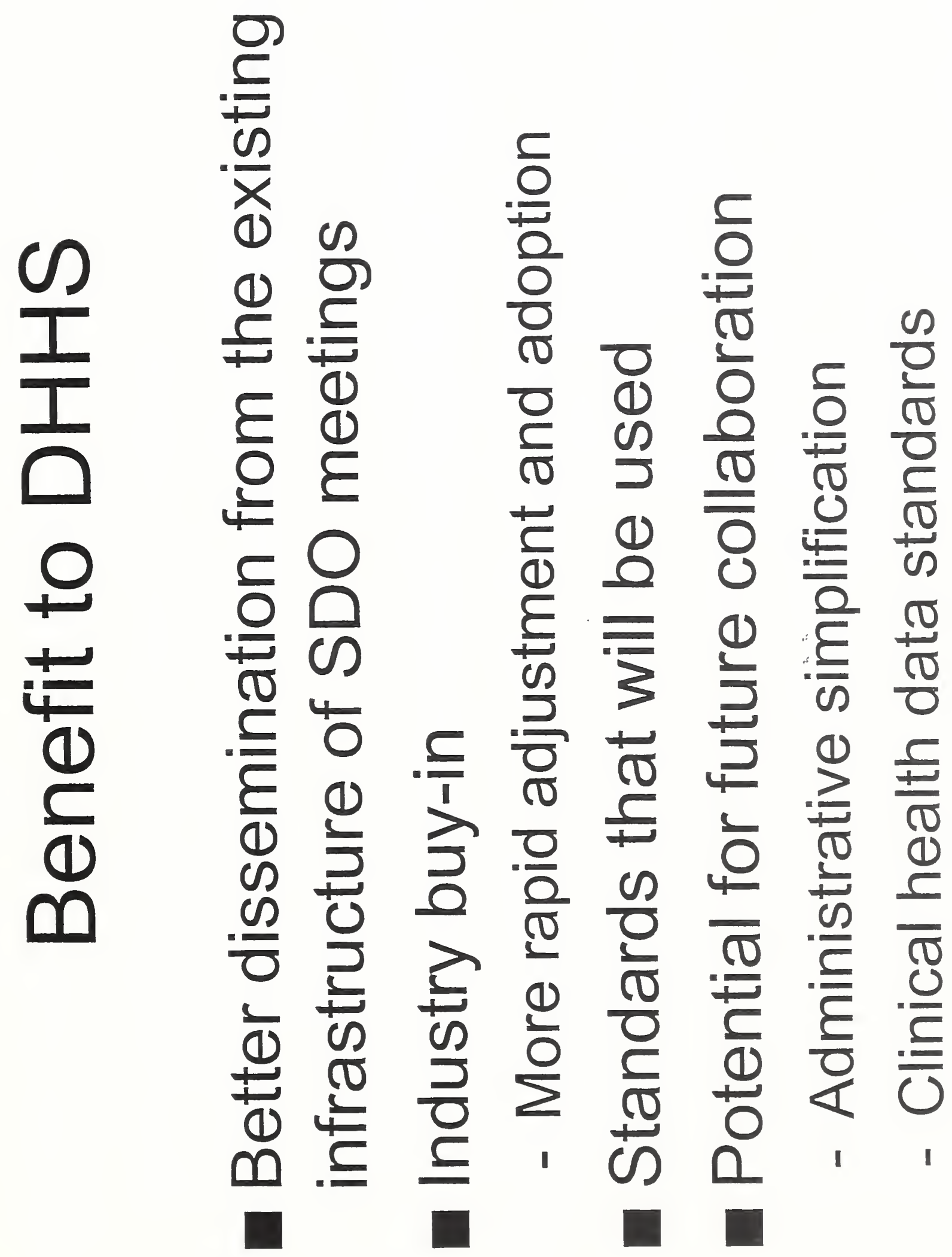




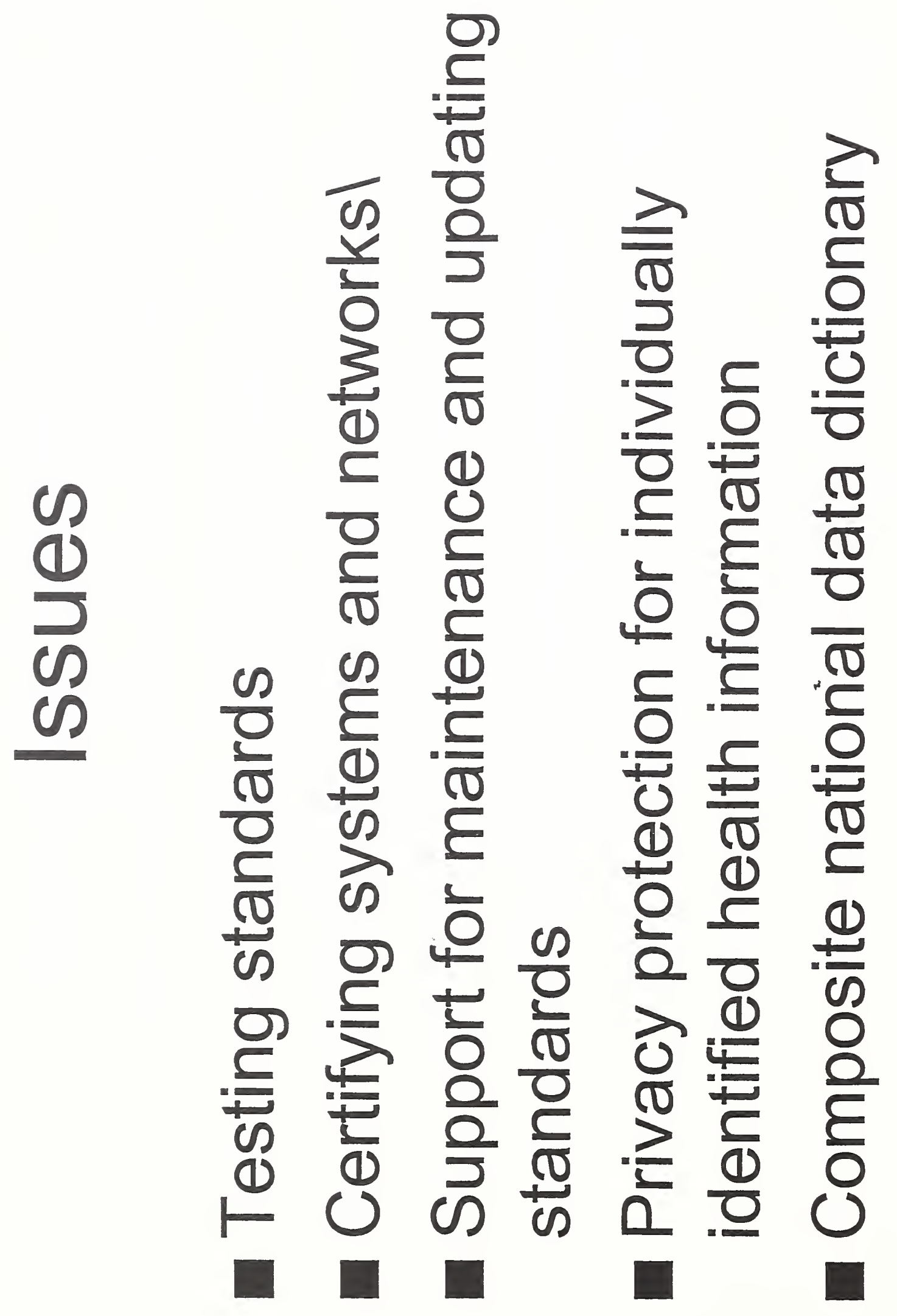




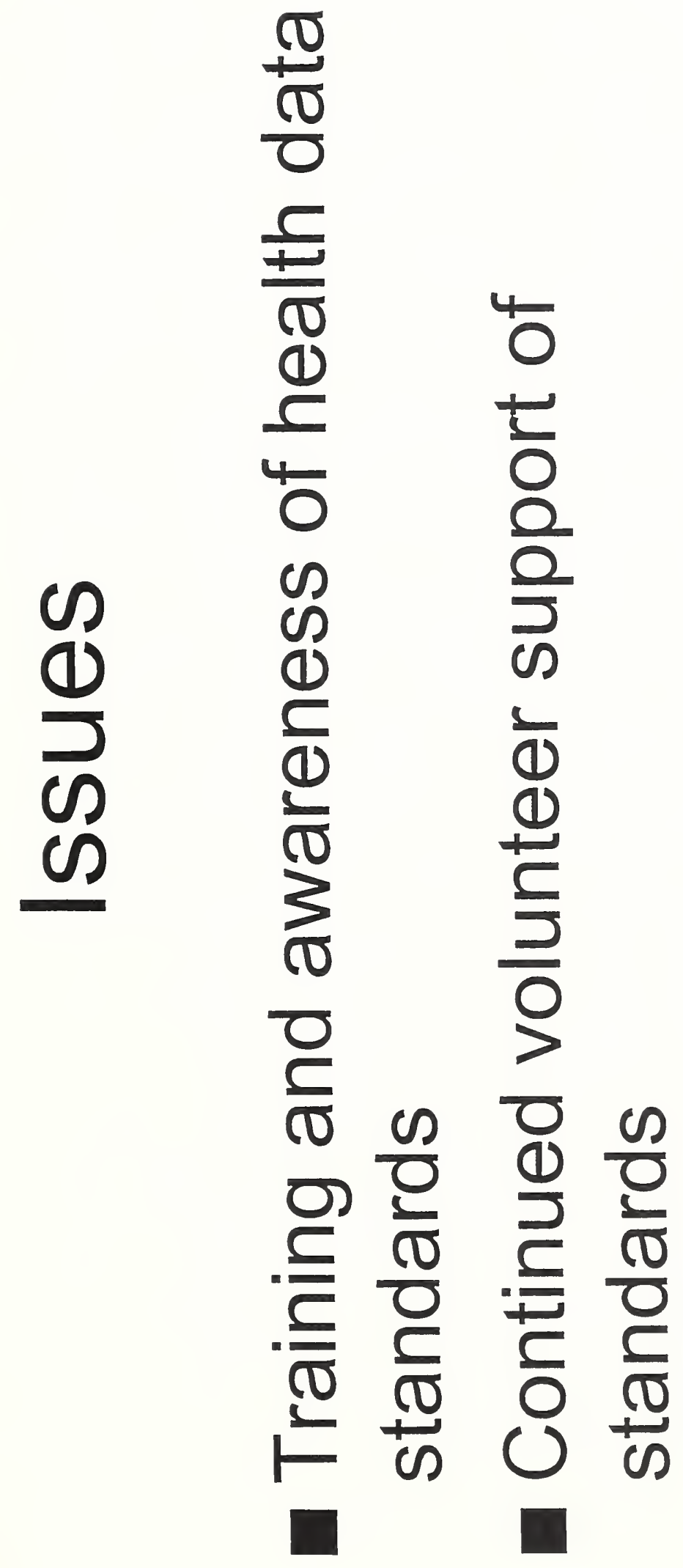


D

II

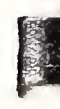

I

I

I

I

(

.

A

.

.

I

II

i

I

II

II

II 

L

.

[1

.

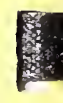

耑

.

5

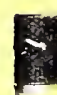

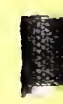

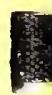

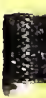

㫋

,

.

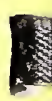

5

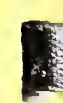




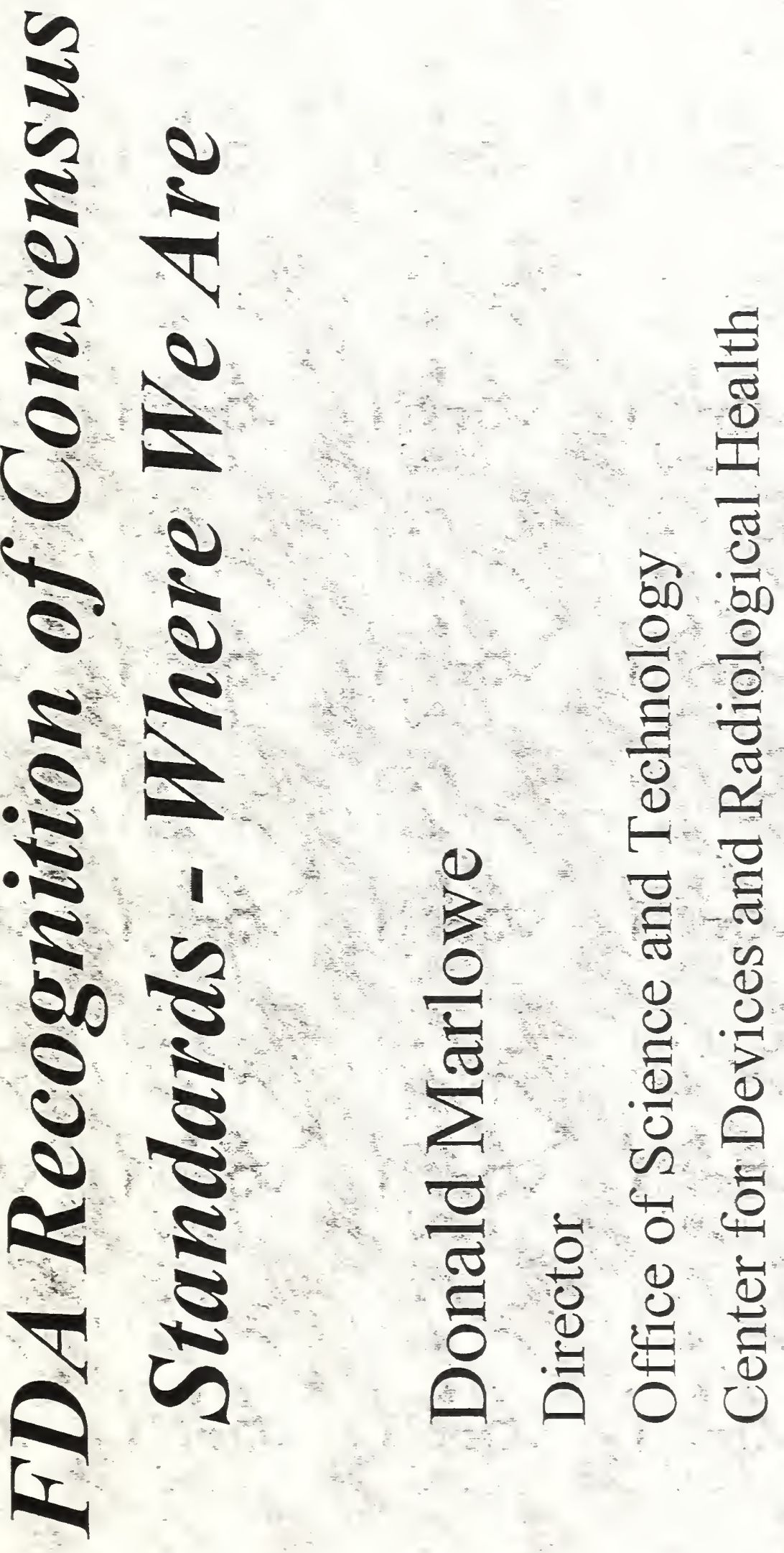

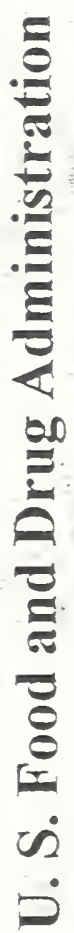
(2) 


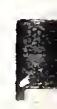

A

. 

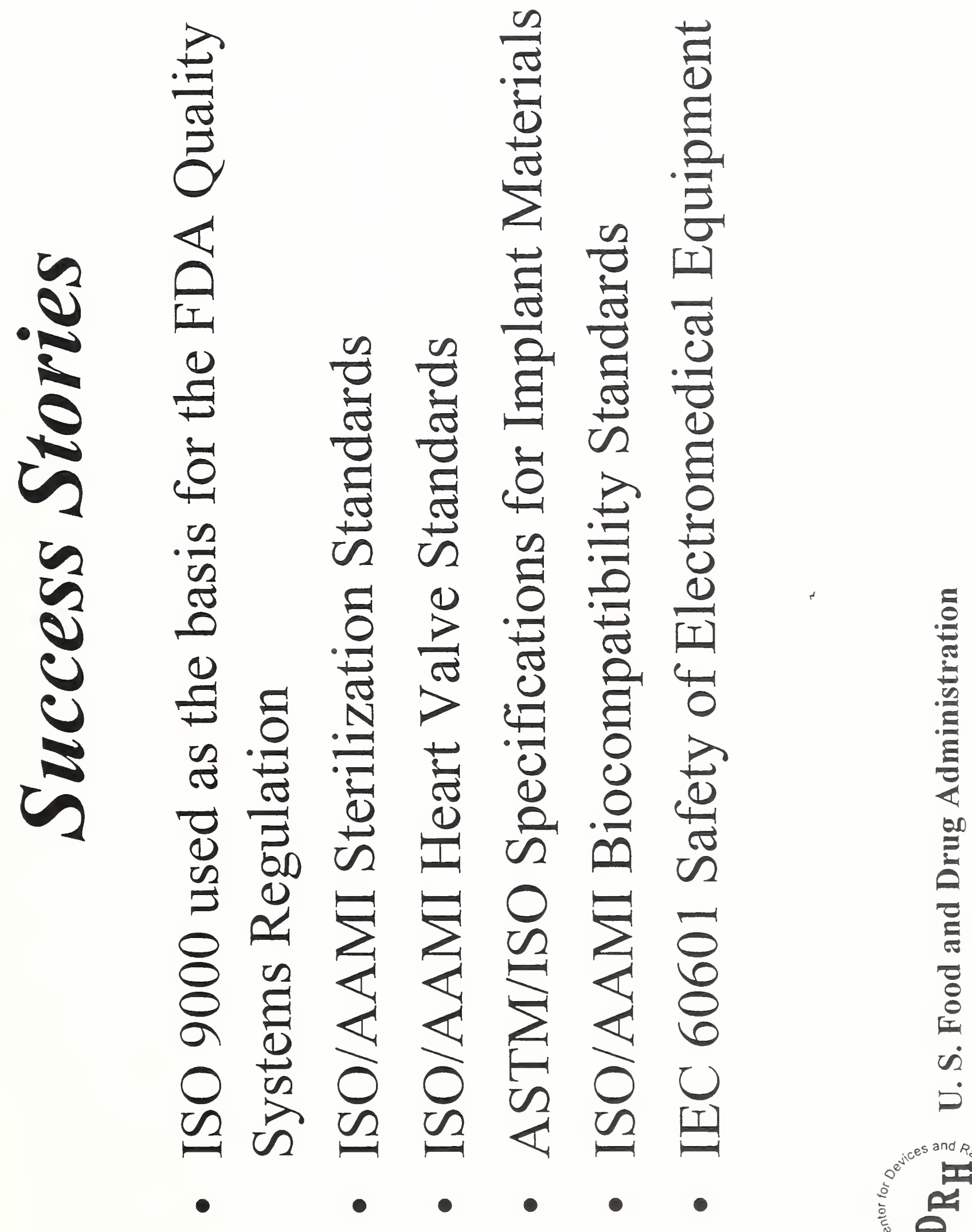


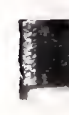

3

E

嫄

隌

אי

F

S

E.

.

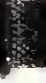

皬

政

列

K

霆

4

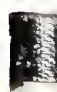




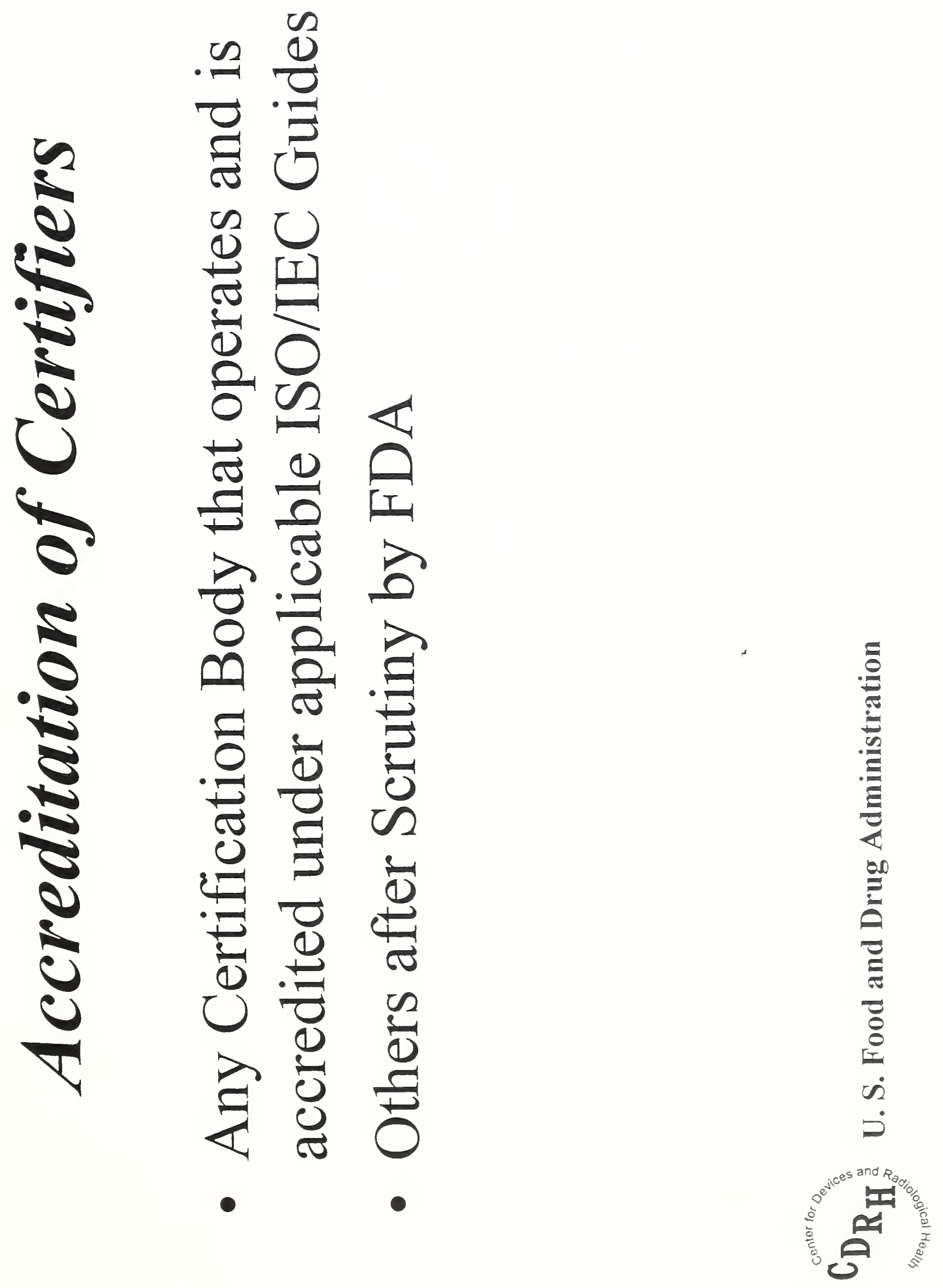




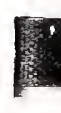

-

a.

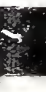

S

.

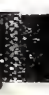

.

(3).

管 


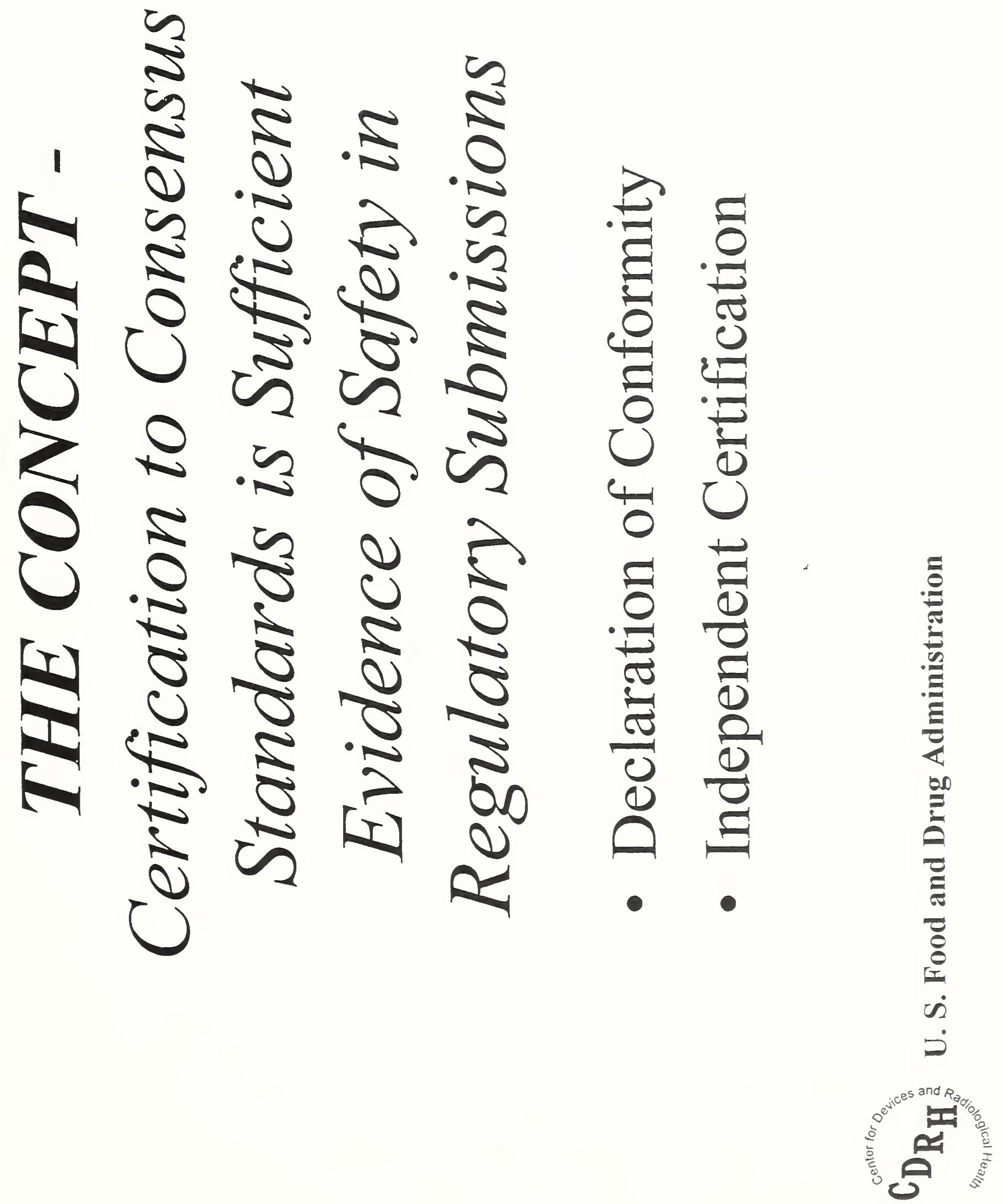


哀

$=$

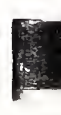

7

.

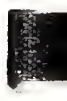

.

数

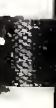

$\sqrt{1}$

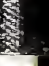

4

is

W 

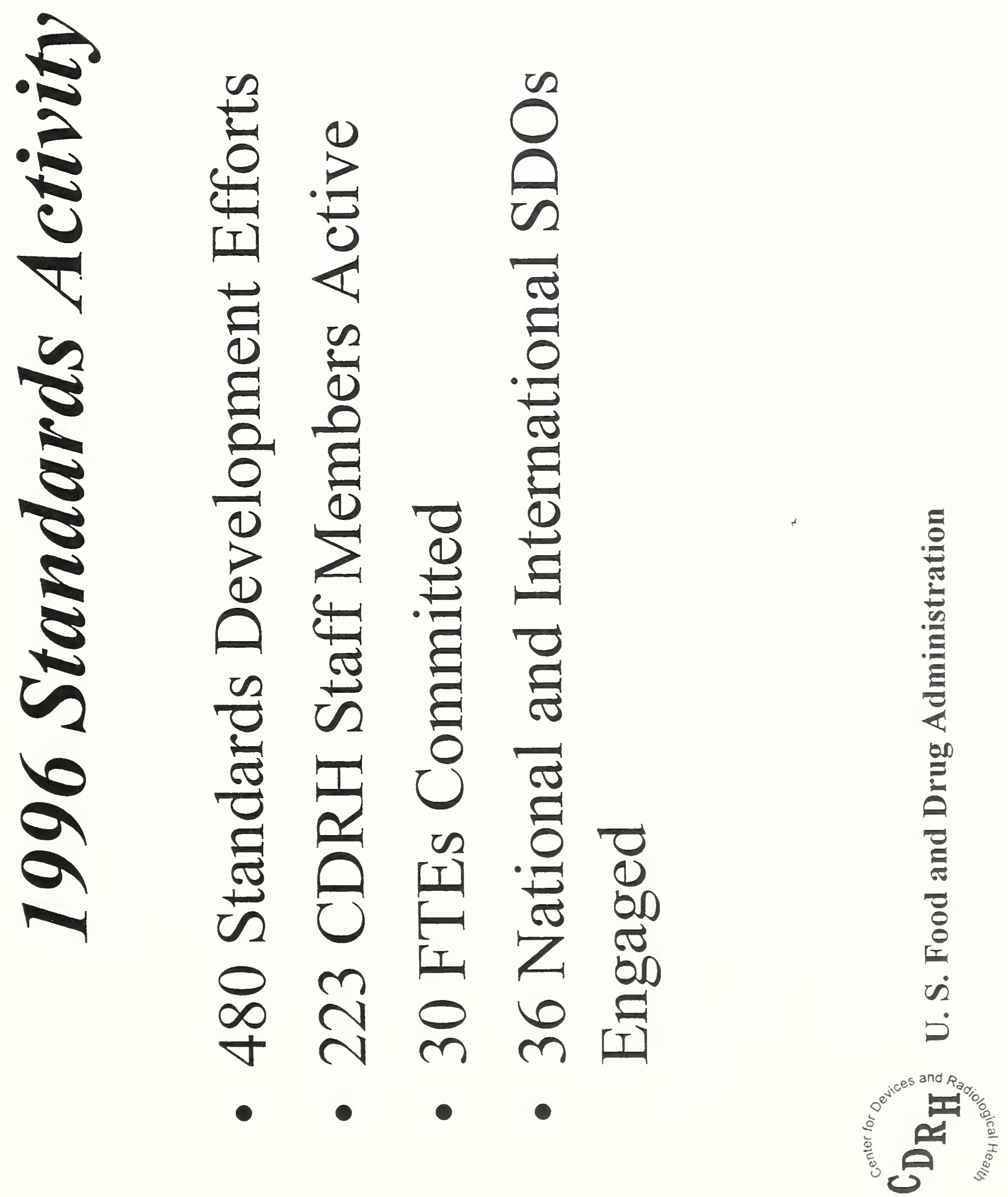


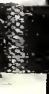

S

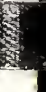





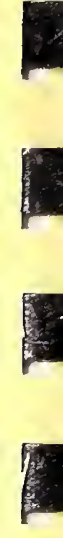




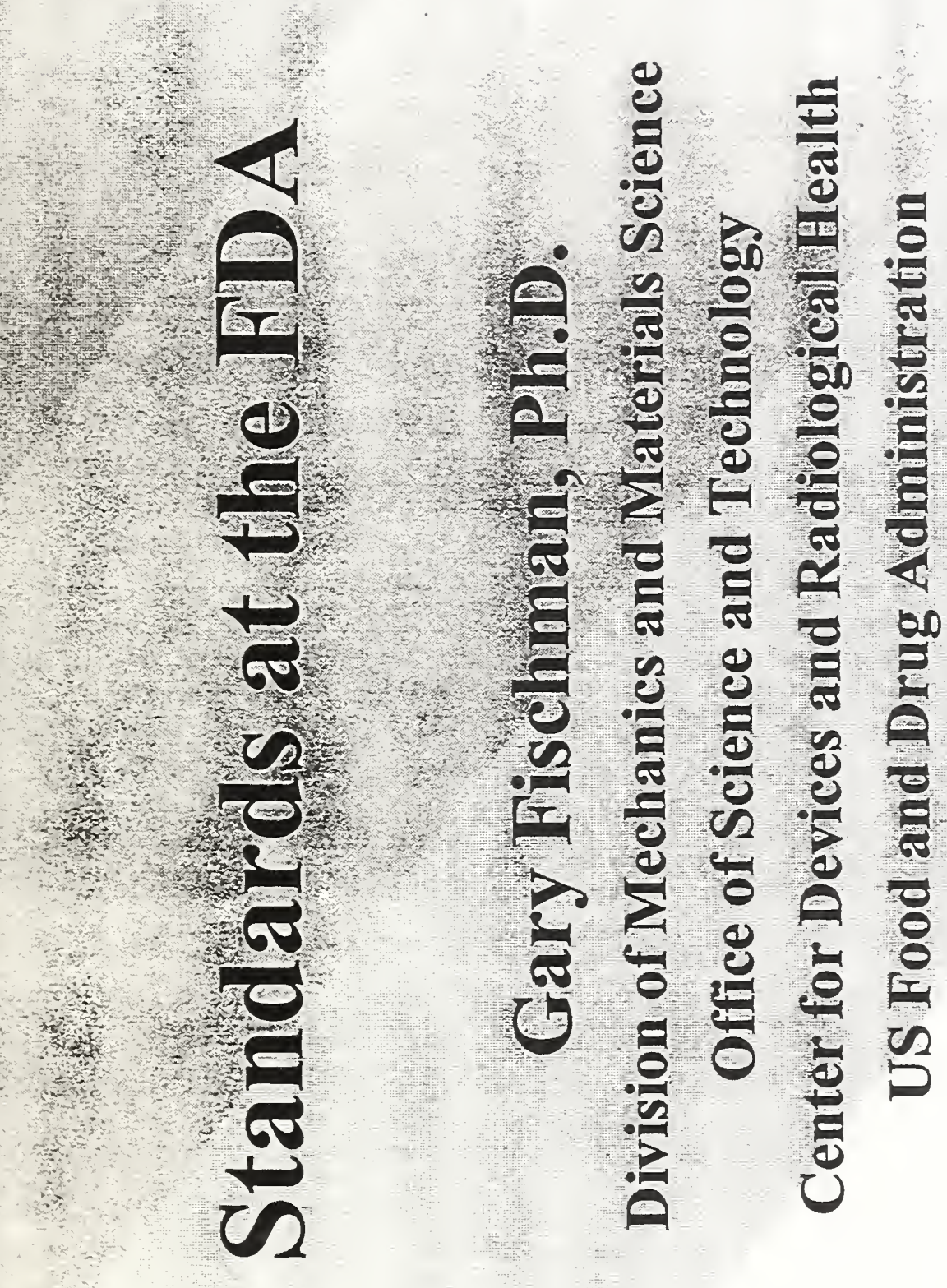

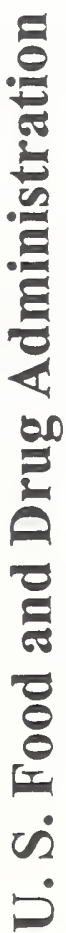

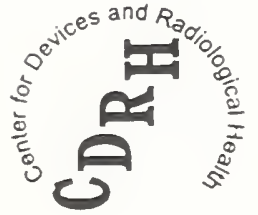




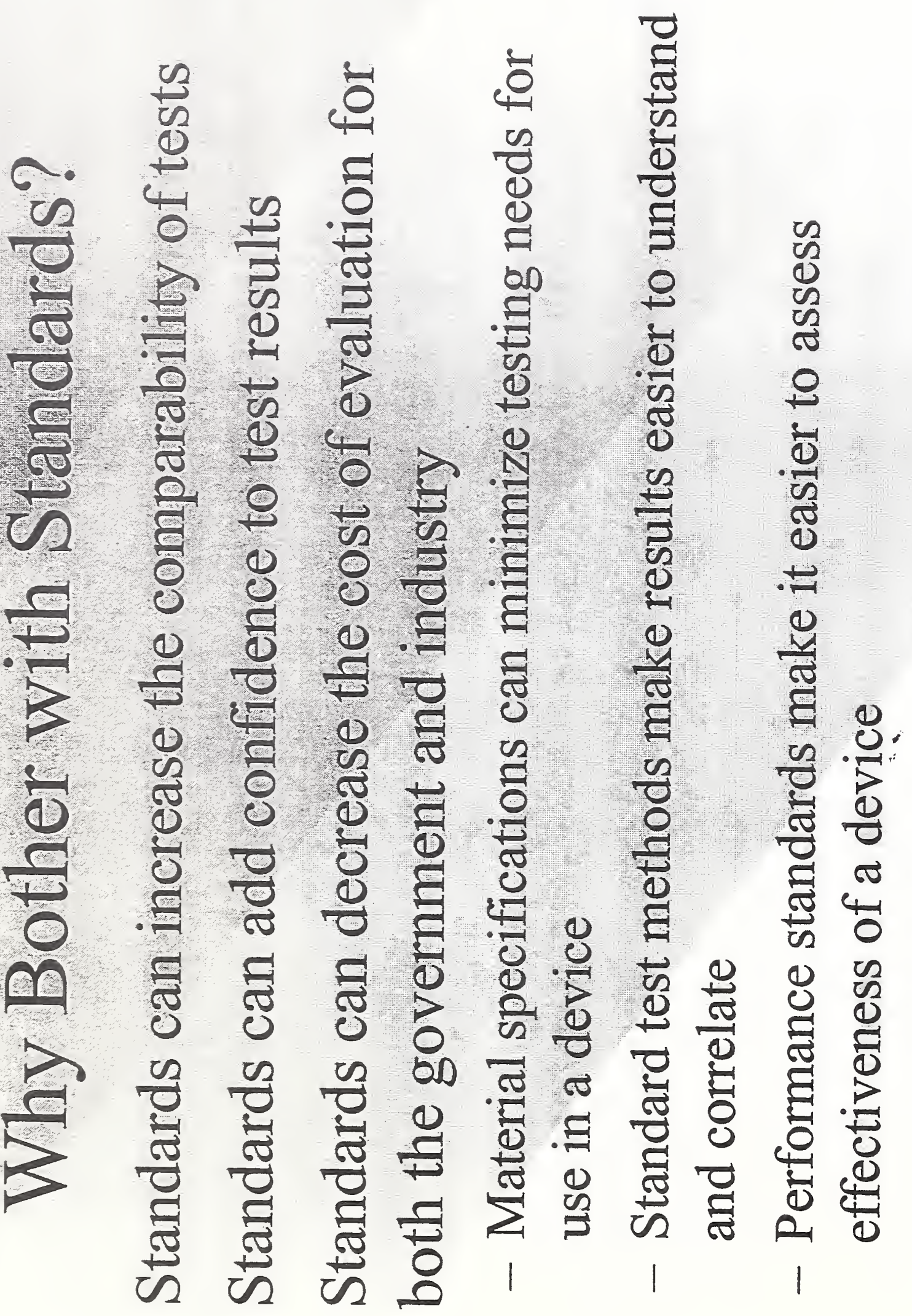

递 (1) 


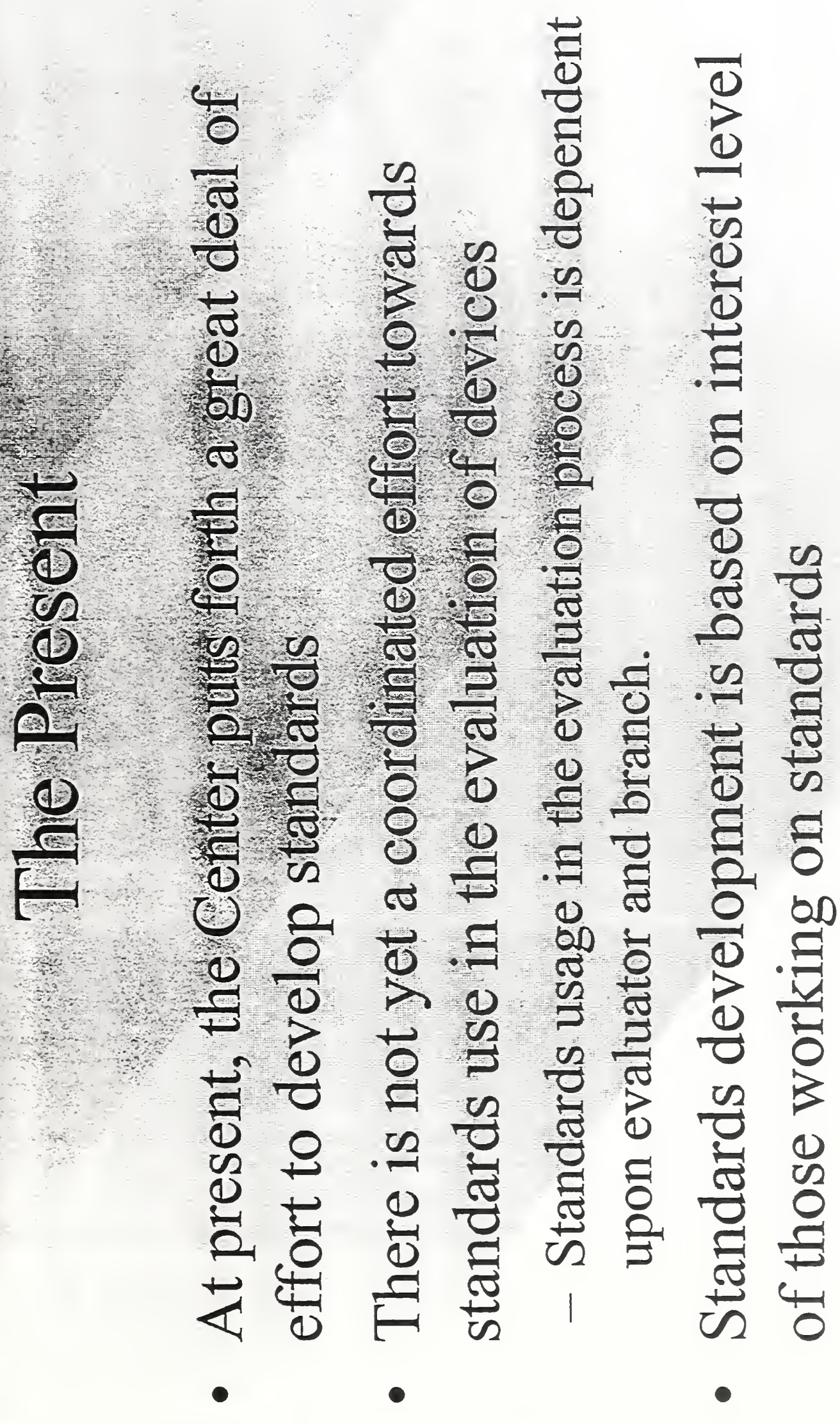

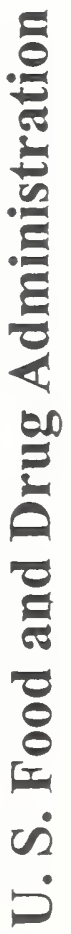

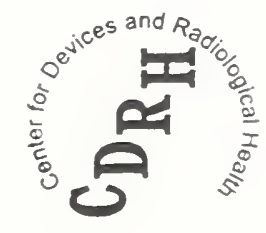




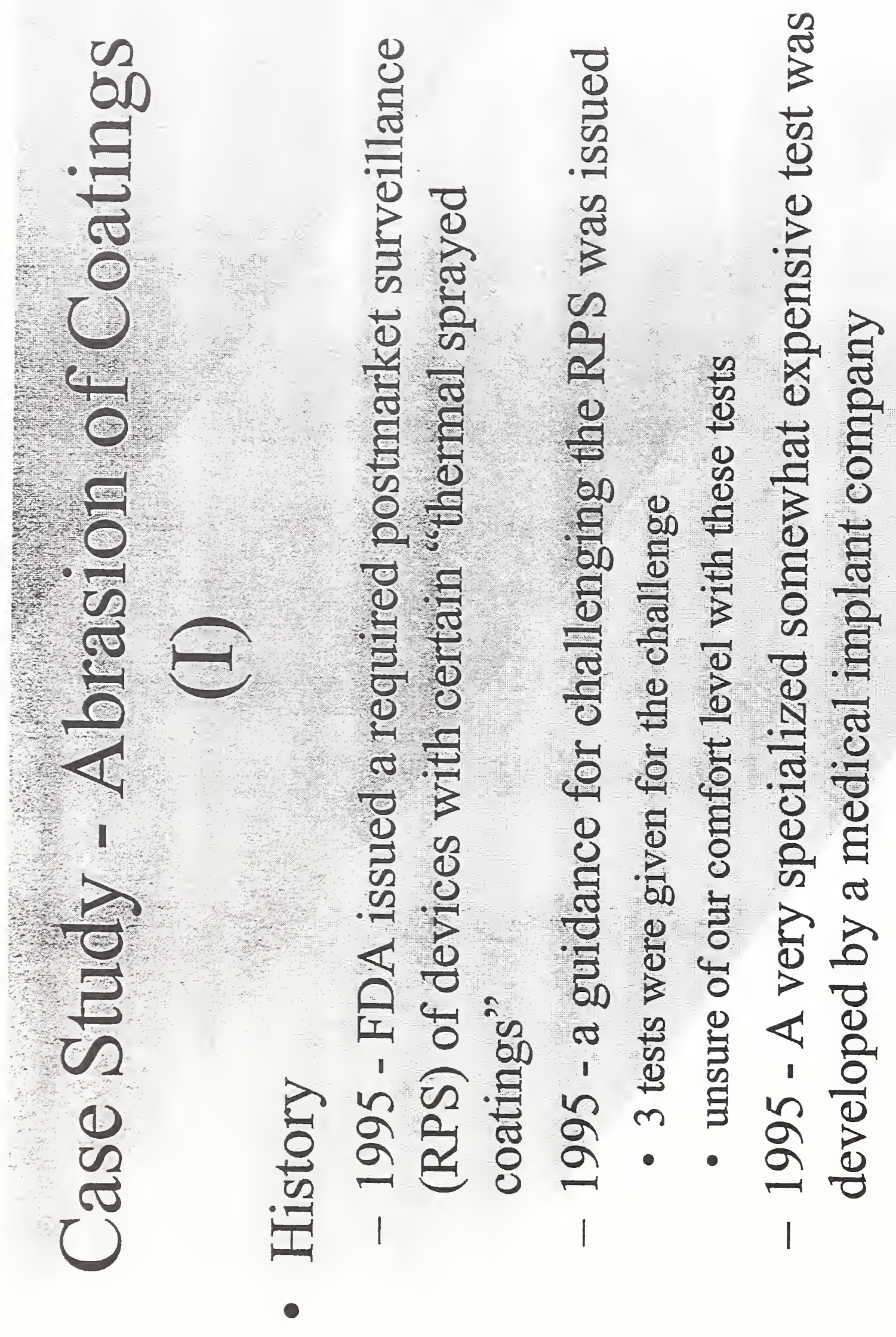

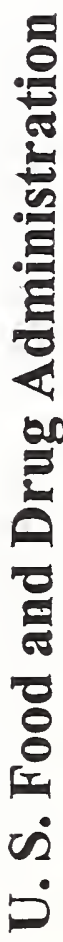

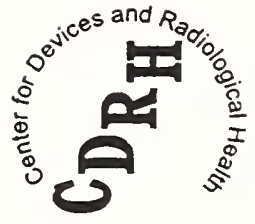




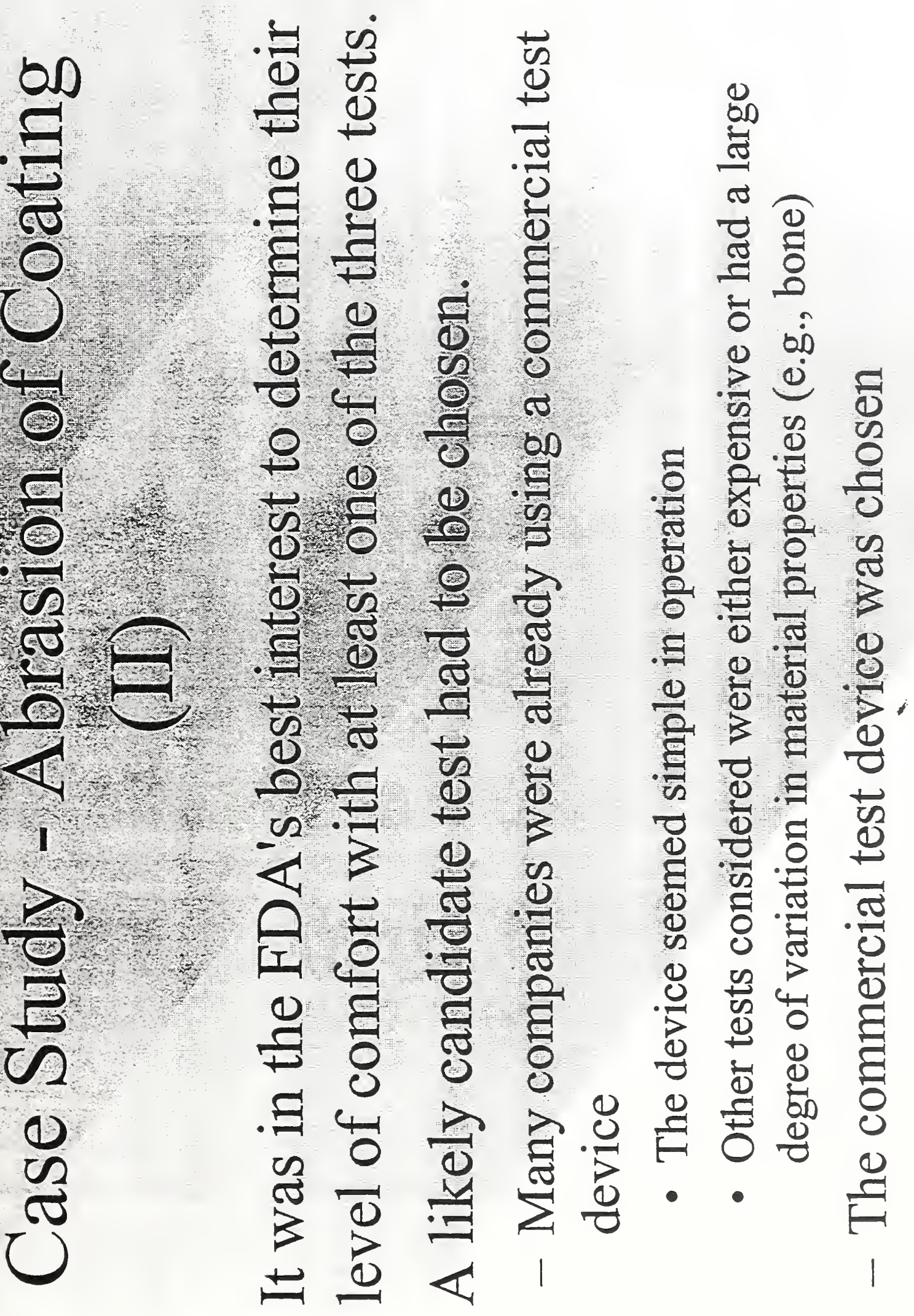

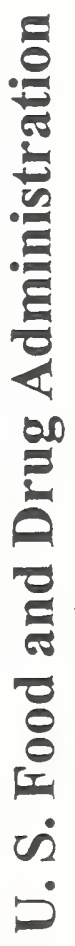

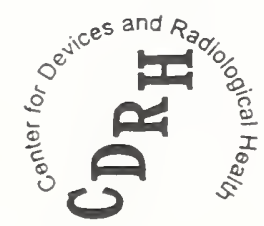



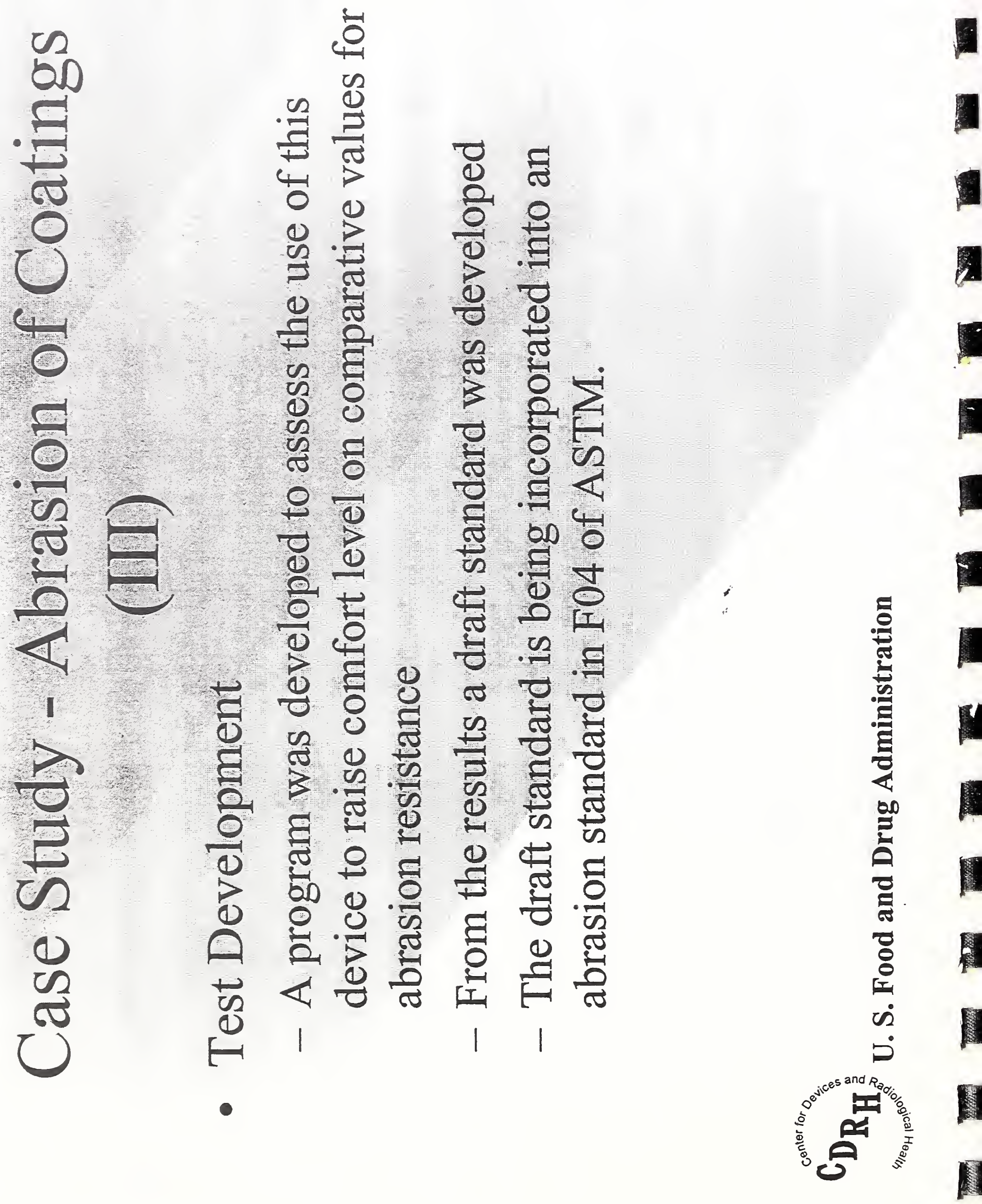


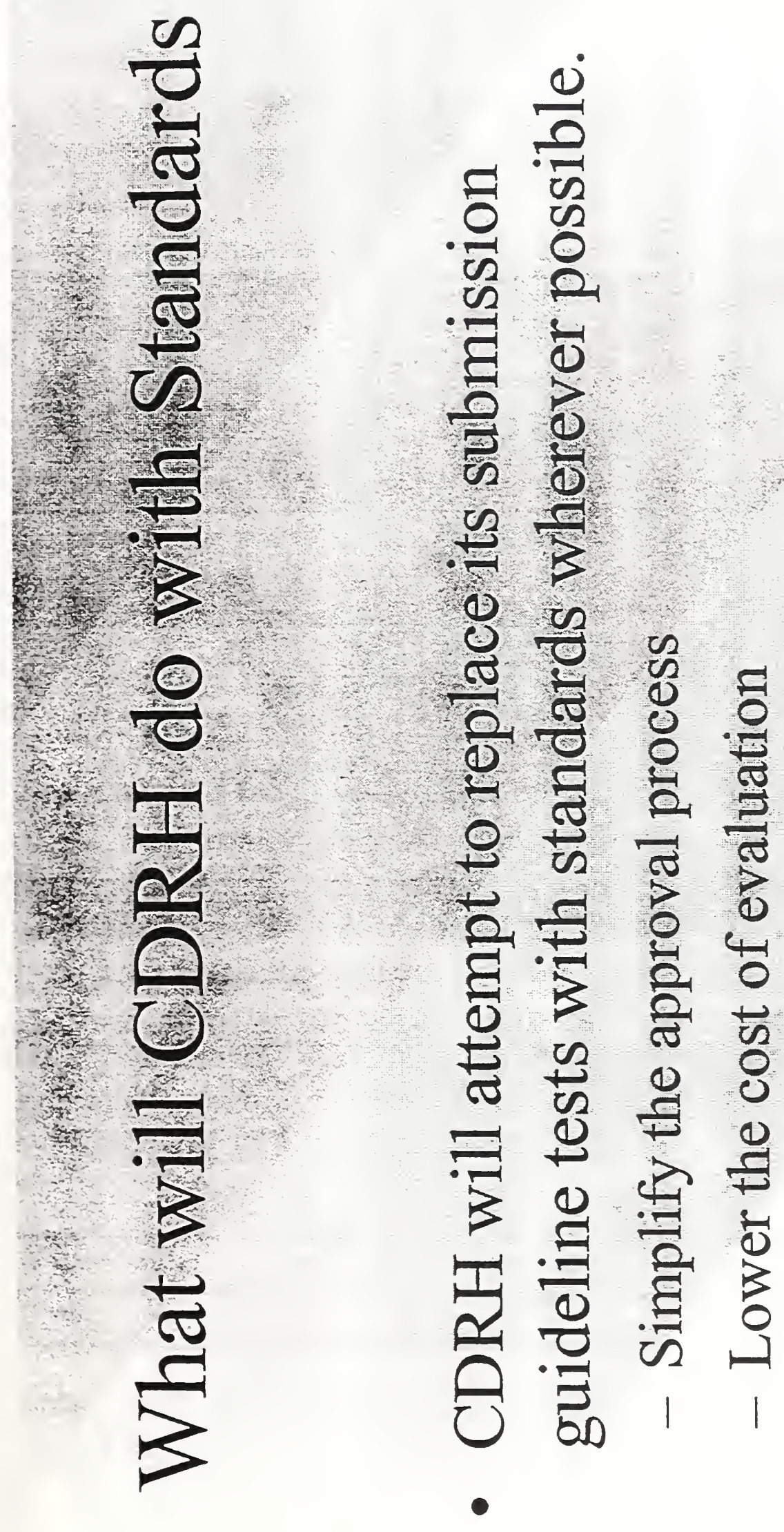

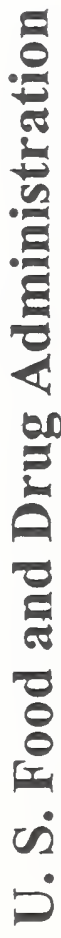

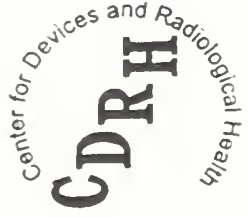



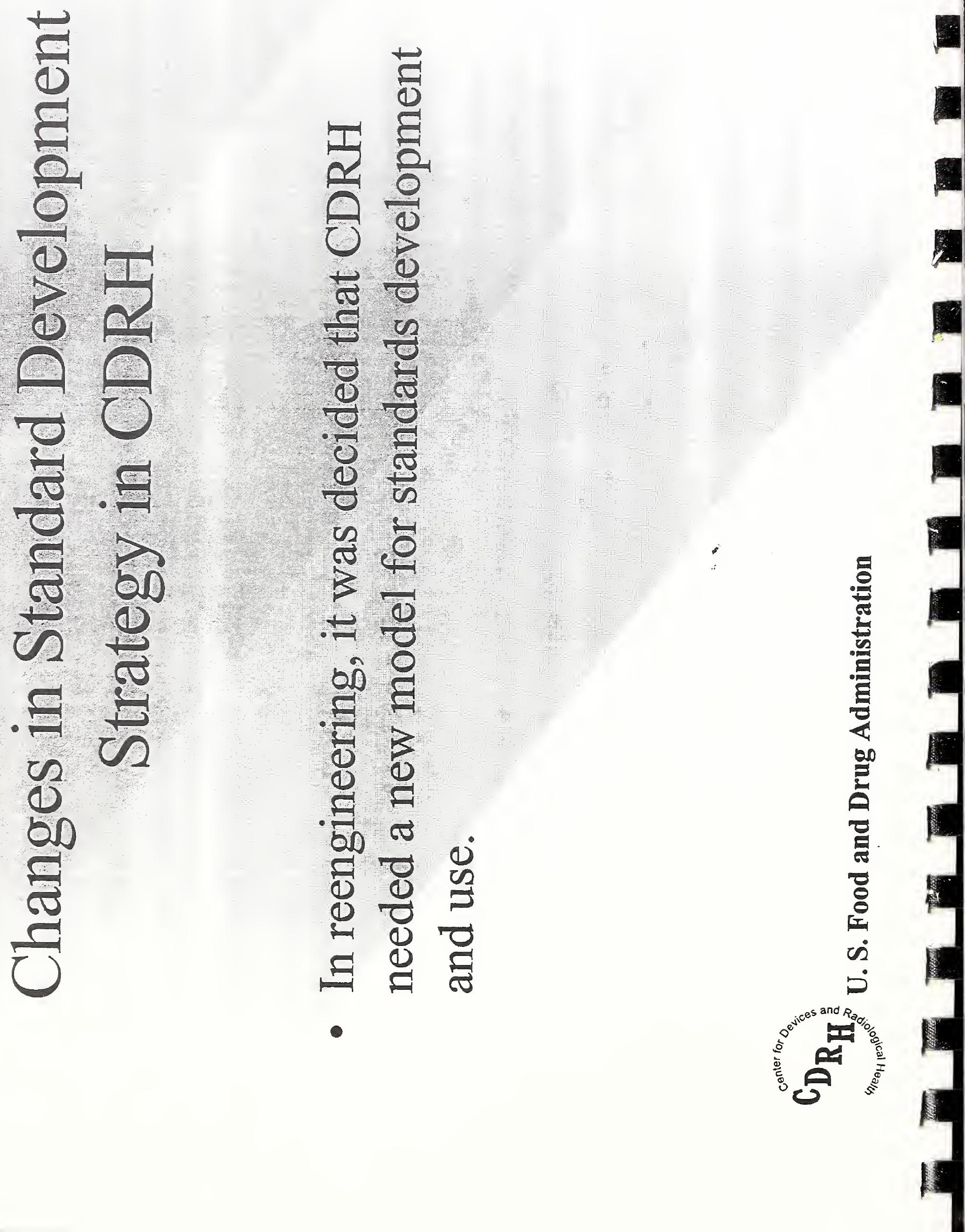


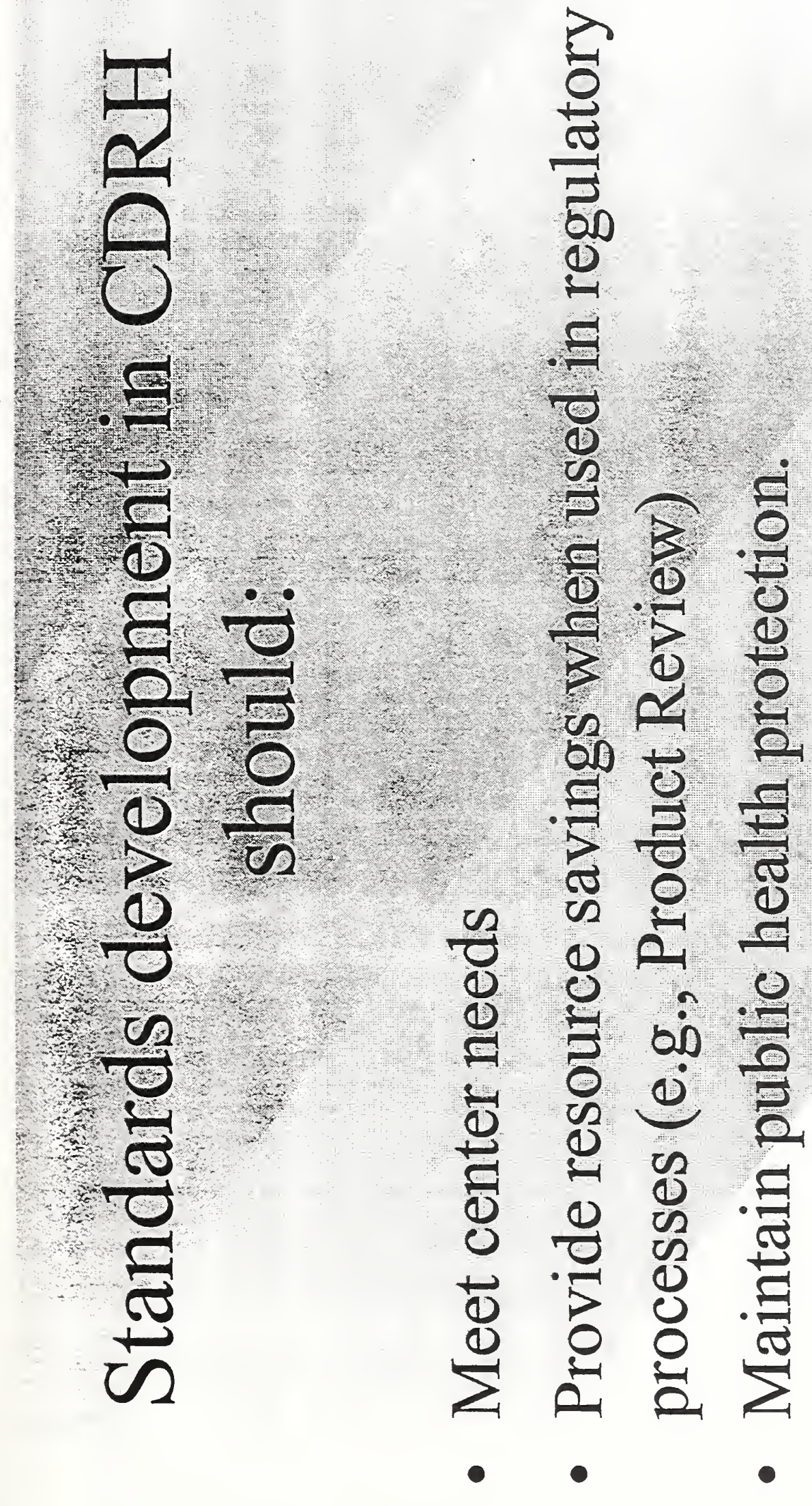

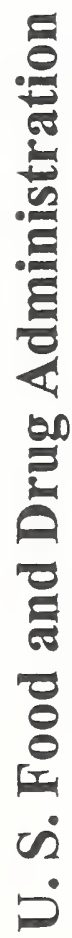
作) 

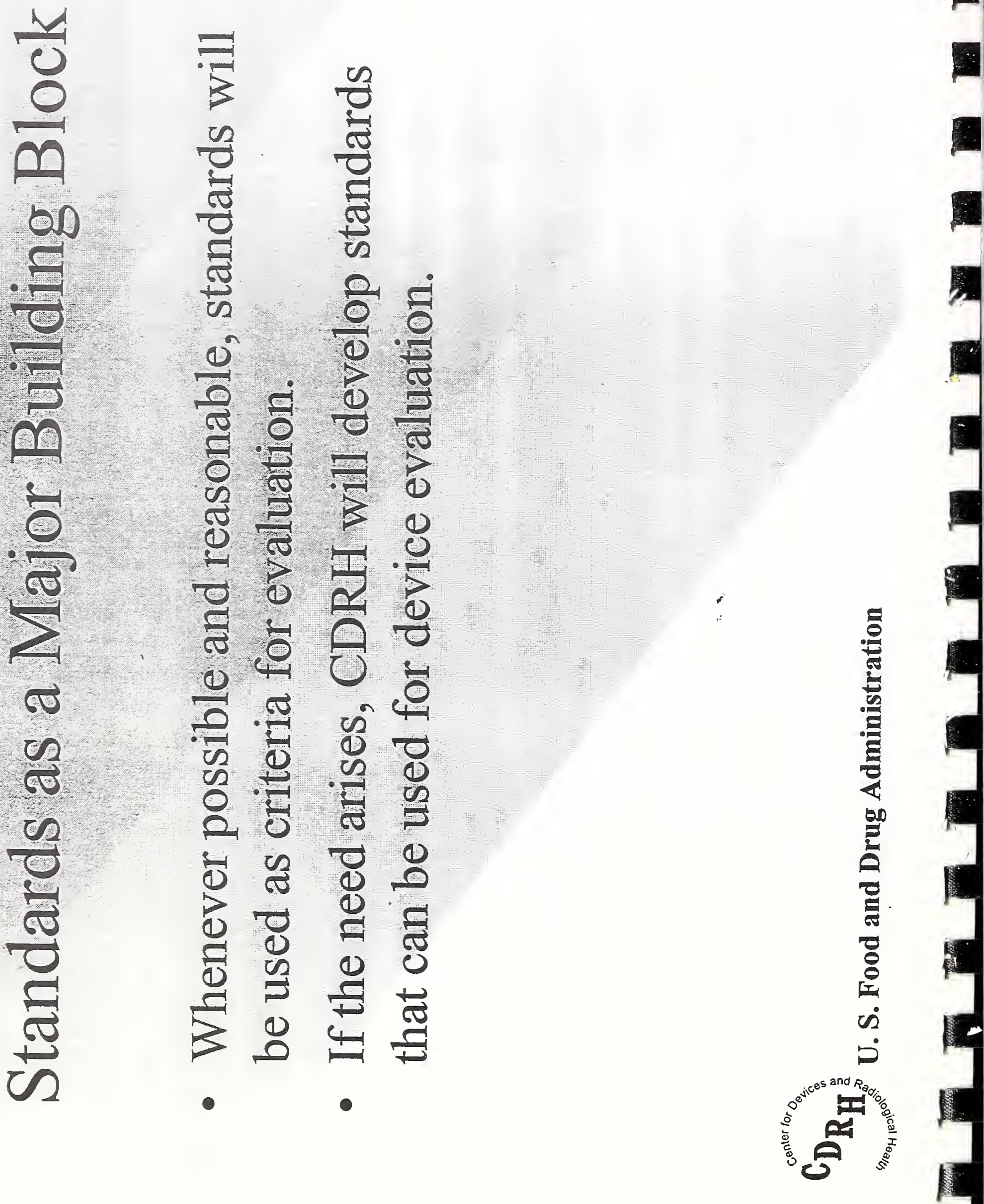


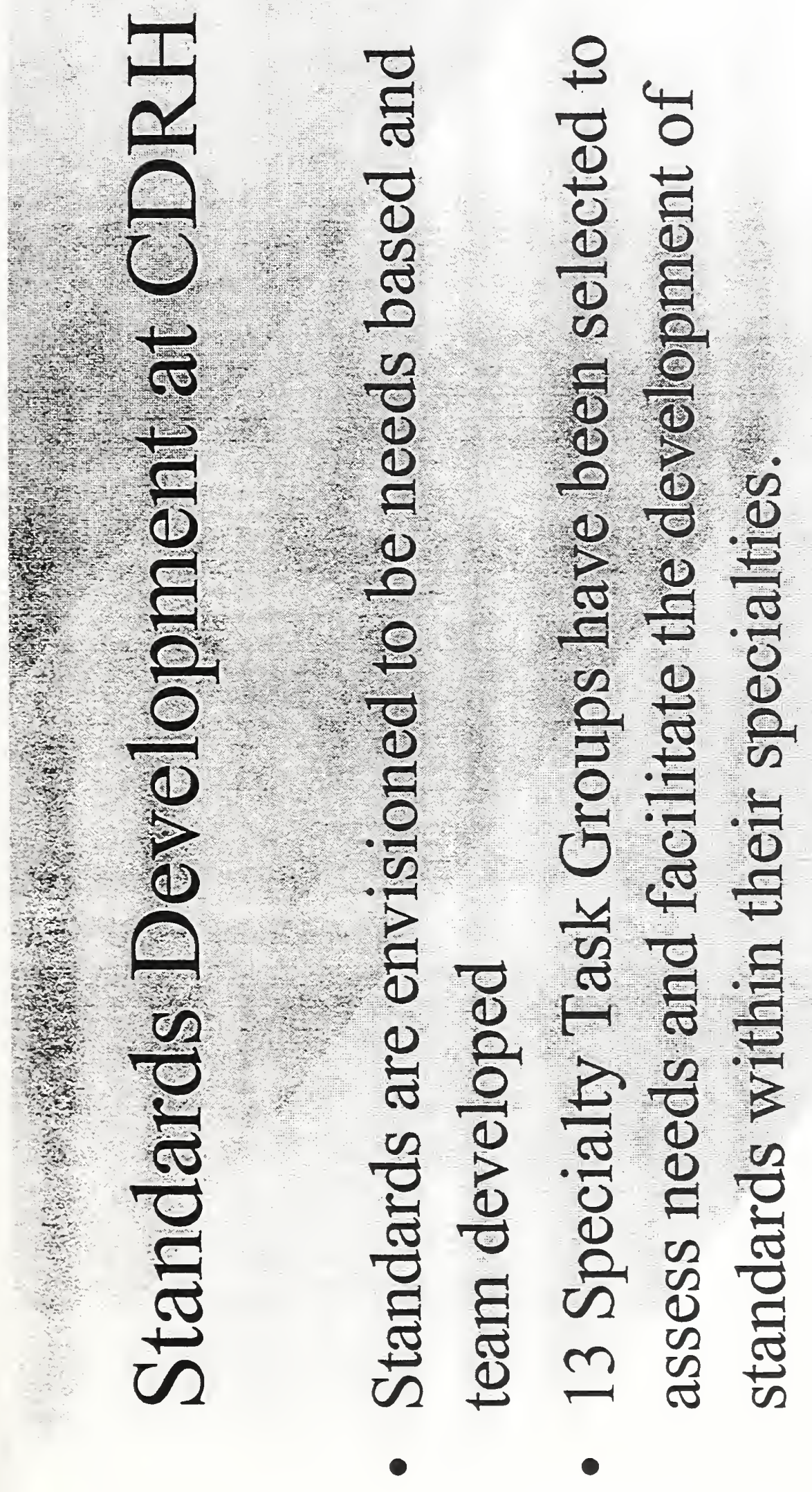

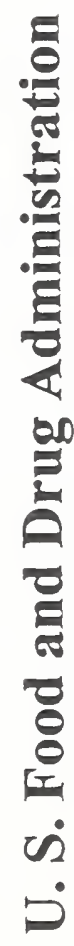

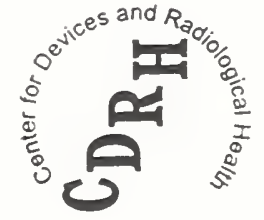




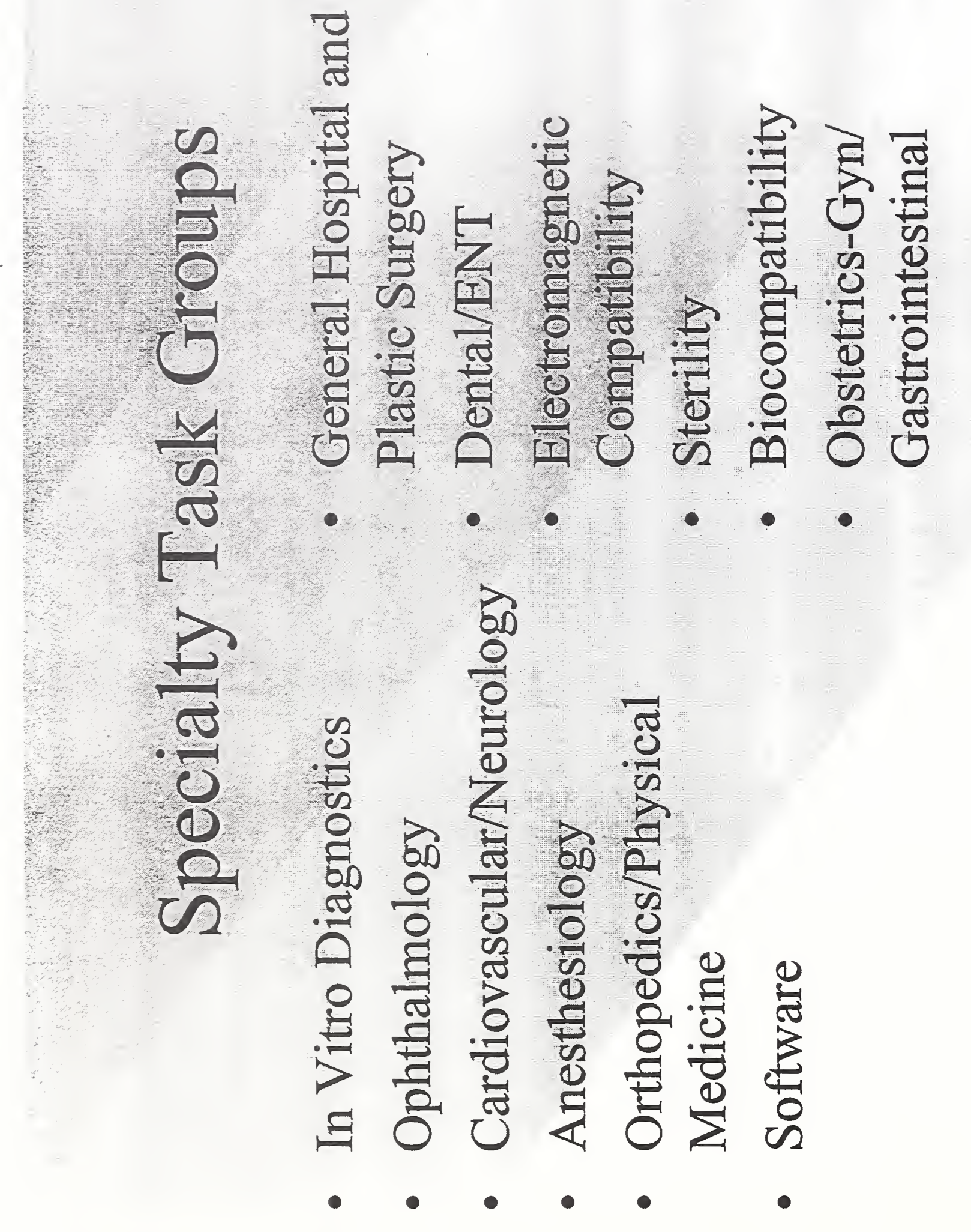



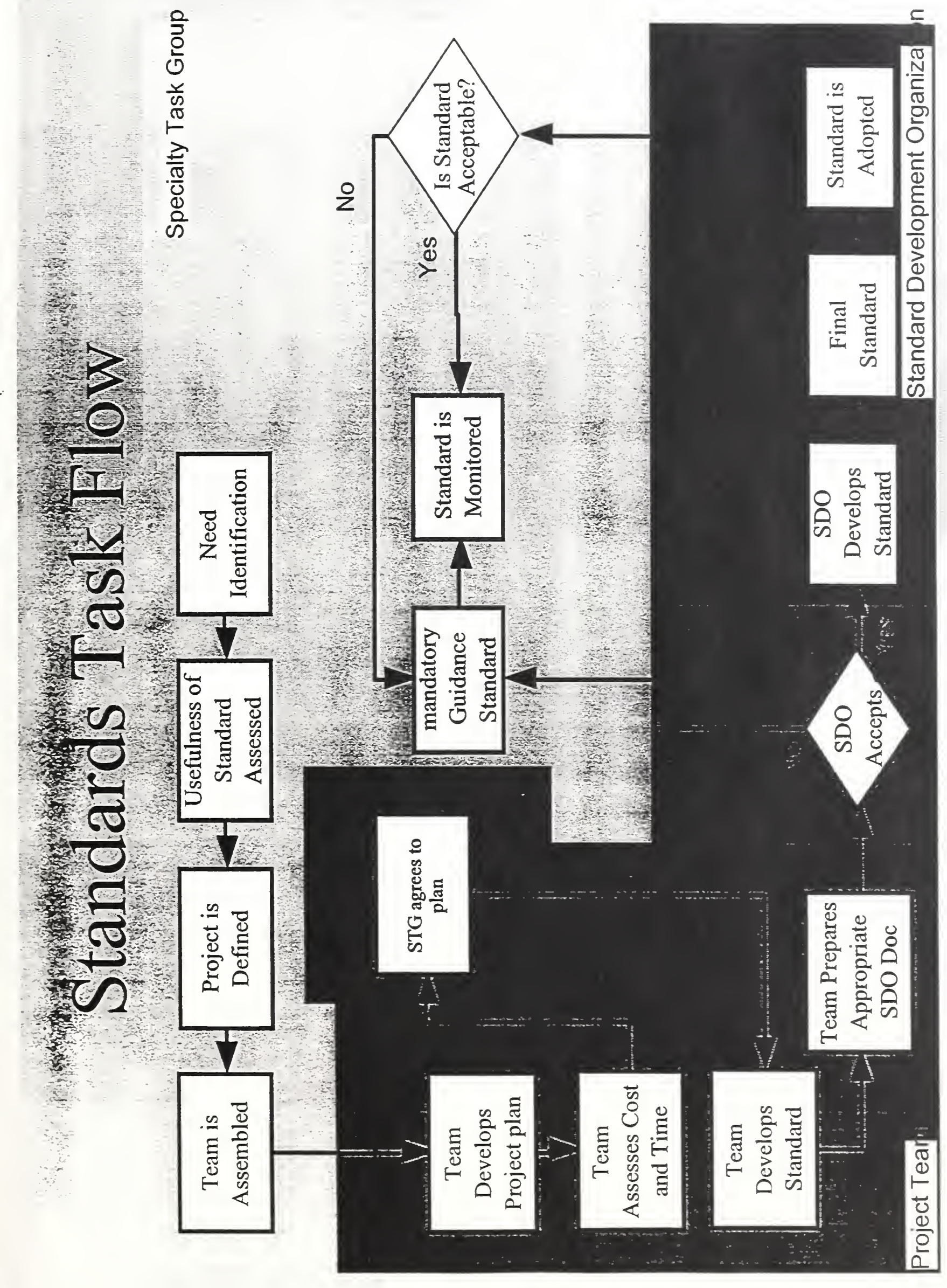

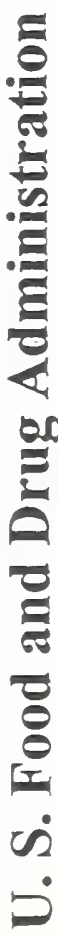

$0^{\text {jices and }}$ है 

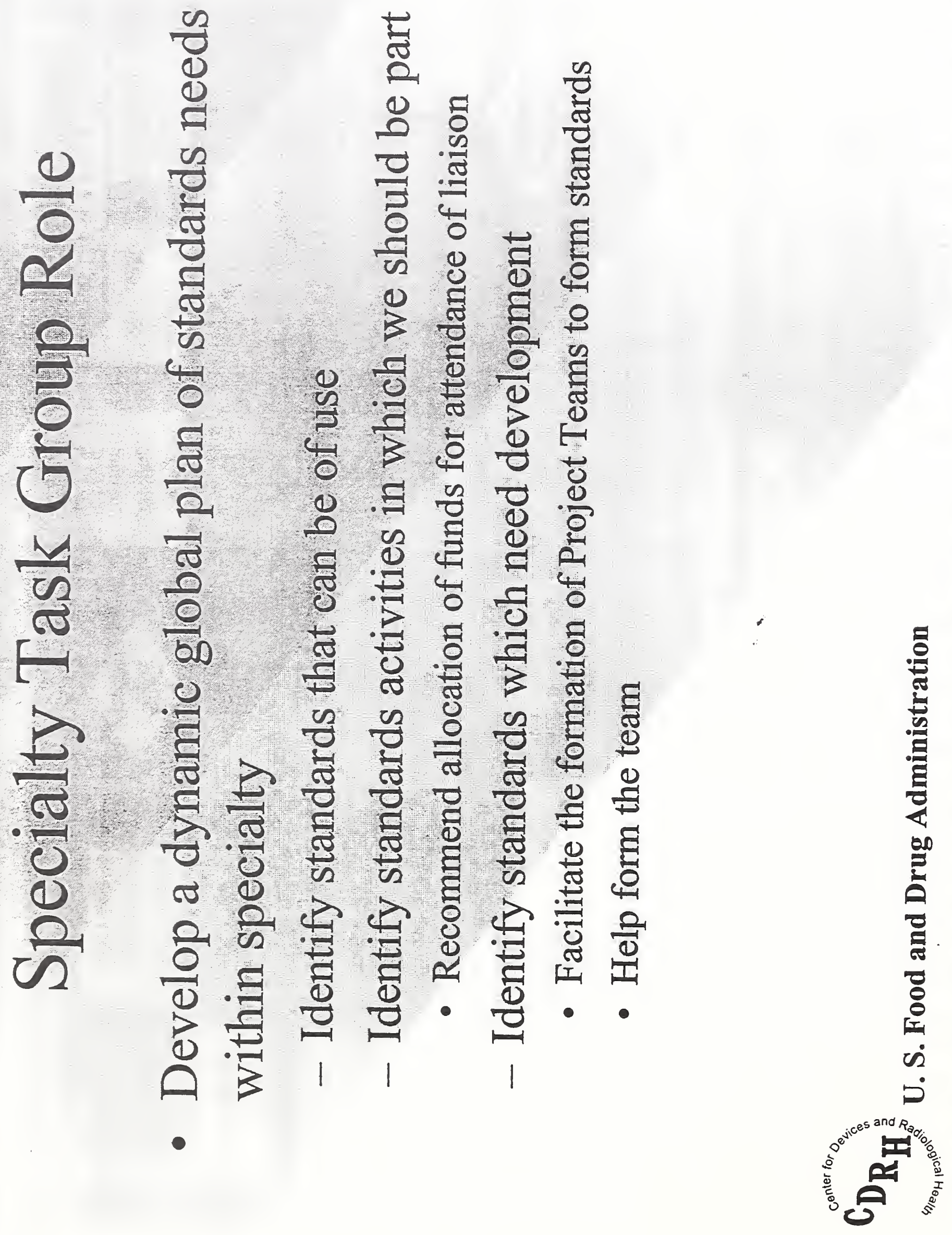


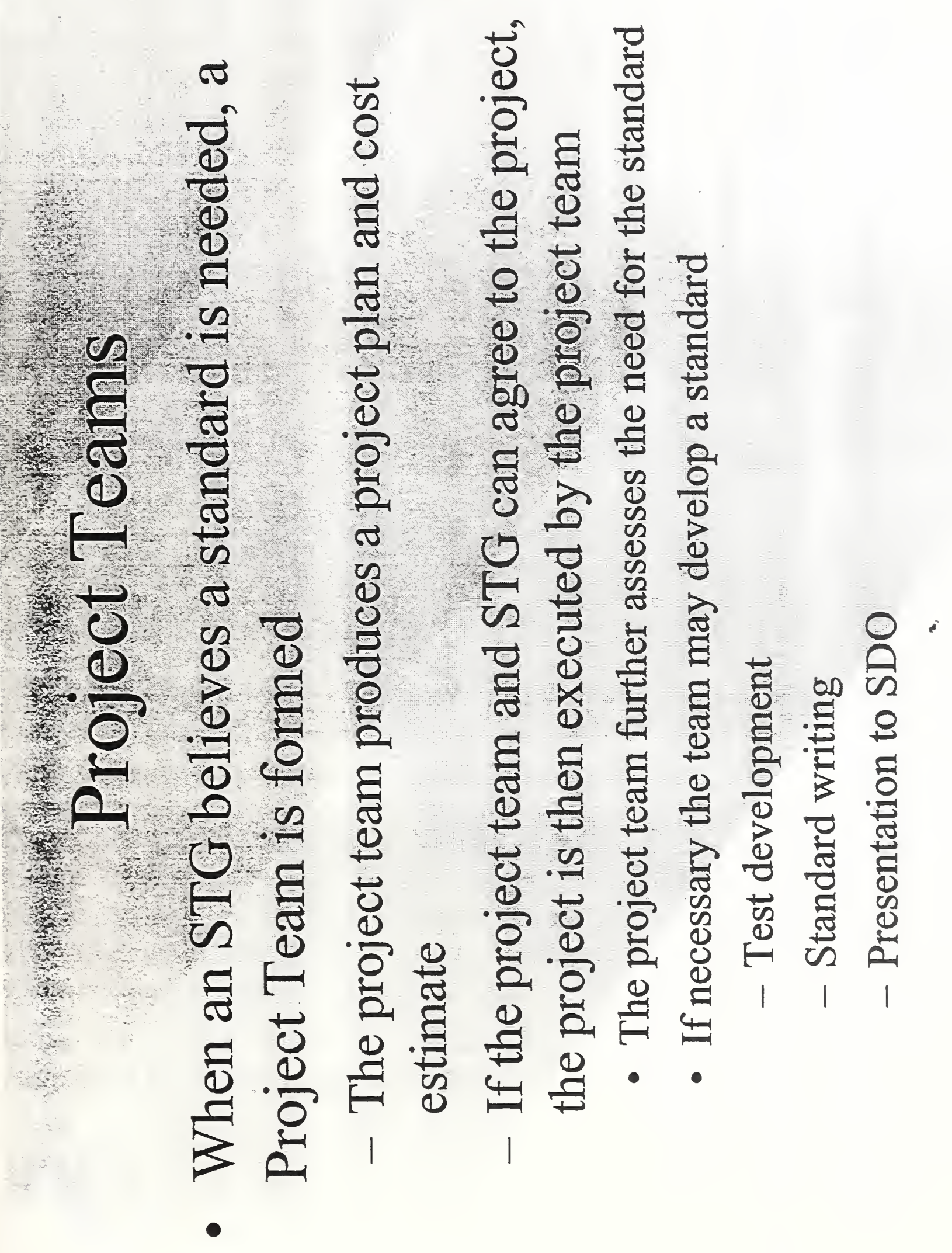



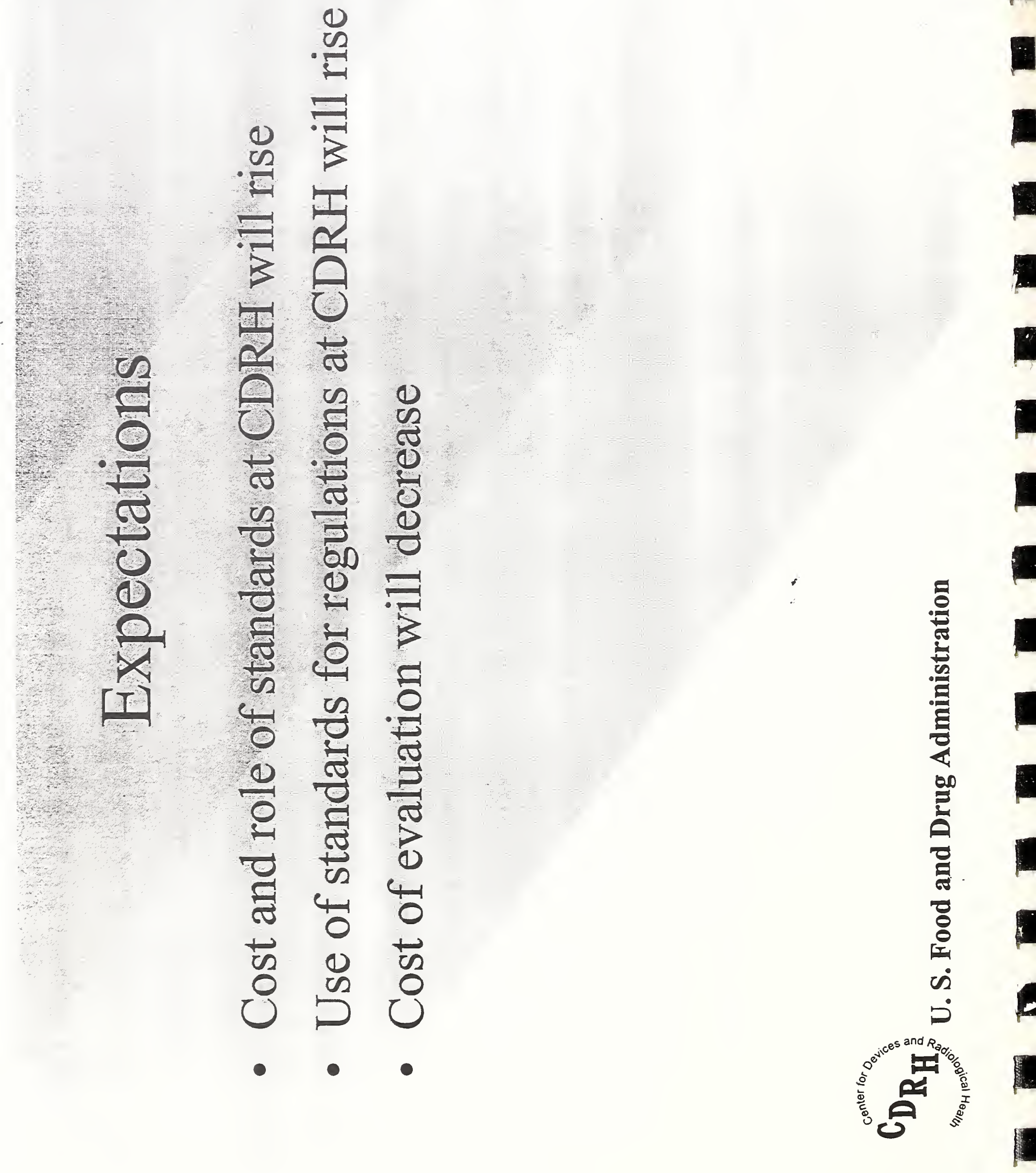


\section{Section 7}

\section{Biographies \\ of}

Moderators and Panelists 


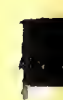




\section{Belinda L. Collins, Ph.D \\ Director, Office of Standards Services \\ National Institute of Standards and Technology}

Dr. Collins is the Director of the Office of Standards Services at the National Institute of Standards and Technology (formerly National Bureau of Standards). The Office of Standards Services provides policy support for standards and conformity activities for regulatory, procurement, and trade agencies of the Federal Government. The Office administers five programs: Global Standards, Laboratory Accreditation, Standards Conformity, Standards Information, and Technical Standards Activities.

Dr. Collins also chairs the Interagency Committee on Standards Policy (ICSP) for the NIST Director. A researcher at NIST from 1984 to 1995. She received her B.A. in experimental psychology from Mary Washington College, and her M.A. and Ph.D. in experimental psychology (vision) from the University of Virginia. Dr. Collins has authored numerous technical publications in the area of lighting and human response. She is a Fellow of the Illumination Engineering Society of North America as well as Society Vice President for Education, and a recipient of the NIST Bronze Medal. 


\section{Sergio Mazza \\ President and Chief Executive Officer American National Standards Institute (ANSI)}

Sergio Mazza was named President and Ceo of the American National Standards Institute (ANSI) by its Board of Directors on November 29. 1993.

ANSI is a not-for-profit membership organization that brings together organizations from both private and public sectors dedicated to furthering U.S. and international voluntary consensus standards and conformity assessments. ANSI accredits national standards developing organizations and approves American National Standards. It is the sole U.S. representative to the International Organization for Standardization (ISO) and the International Electrotechnical Commission (IEC), via the U.S. National Committee.

Before accepting the position of ANSI President, Mr. Mazza was active as a software entrepreneur, most recently as President of DS Group, Inc. Mr. Mazza's corporate career included the position of President of Memorex Computer Supplies, where he also served on the boards of Memorex Technologies, Inc., U.S.A. and Memorex Copal Corp., Japan. Prior to that he was President of Memorex U.S.A.

Mr. Mazza holds a B.S. degree in economics with a dual major in finance and multinational enterprises from the University of Pennsylvania's Wharton School. He speaks four languages fluently, and has lived in seven different countries. 


\section{Richard E. Feigel, Ph.D \\ Vice President, Engineering \\ Hartford Steam Boiler Inspection \& Insurance Co.}

Dr. Feigel is responsible for engineering and corporate quality initiatives in service delivery, training, risk evaluation and loss prevention. He assists internal and external clients in defining and implementing cost effective risk management and engineering programs. He has over 20 years experience with his company with expertise in quality assurance, ASME codes and standards and risk assessment. His previous experience includes pressure vessel construction, welding, radiography, quality assurance.

Professional Designation(s): Fellow, American Society of Mechanical Engineers

Professional Affiliations: American Society of Mechanical Engineers, Member, American Welding Society, Member

Professional Activities:

Chairman and Senior Vice President, ASME Council on Codes and Standards

Past Chairman, ASME Board on Council Operations

Past Vice President, ASME Board on Pressure Technology Codes and Standards

Welding Research Council, Board of Directors

ASME Boiler and Pressure Vessel Code Main Committee

ASME Code for Pressure Piping, Past Chairman

Dr. Feigel has numerous copyrights, patents and publications. 


\section{Howard L. Hime \\ Chief, Office of Standards Evaluation and Development \\ U.S. Coast Guard}

Howard L. Hime is Chief, Office of Standards Evaluation and Development for the U.S. Coast Guard. This Office is responsible for development of all Coast Guard regulations relating to marine safety and environmental protection.

Mr. Hime is a registered Professional Engineer and certified nuclear power plant engineer. He has been responsible for the design of nuclear power plants, manned deep ocean simulators, diving systems, offshore structures, and advanced weapons development.

Mr. Hime has been with the U.S. Coast Guard for 20 years and has been involved in standards development for 28 years in the fields of boilers, pressure vessels, materials, welding, and ships and marine technology. Mr. Hime has received ASTM's coveted John Hass Memorial Award and ASME's Dedicated Service Award for his outstanding leadership and support for standards development. Mr. Hime has also received the National Society of Engineers Engineer of the Year award for his efforts in developing and promoting the use of standards. And recently, Mr. Hime was awarded the Vice President's Hammer award for his achievements in regulatory reinvention. 


\section{Richard B. Felder \\ Associate Administrator \\ Office of Pipeline Safety \\ Department of Transportation}

Richard Felder is Associate Administrator for Pipeline Safety at the U.S. Department of Transportation's Research and Special Programs Administration. The Office of Pipeline Safety administers the Federal regulatory program to assure safe and environmentally sound transportation of natural gas, petroleum, and other hazardous liquids by pipeline. $\mathrm{He}$ is also responsible for developing regulation and other approaches to risk management to assure safety in design, construction testing, operation maintenance and emergency response of pipeline facilities.

Mr. Felder has been a force for regulatory change in government and the private sector. He managed both trucking and railroad programs at the Interstate Commerce Commission (ICC) where he implemented the Staggers Rail Act and the Motor Carrier Act of 1980. Mr. Felder also served as Vice President for Government Affairs at TransAmeria Interway, acting as both corporate officer and representing the company's interests before executive departments, Congress, and a variety of regulatory agencies. He also served as a partner at the law firm of Amall, Golden and Gregory in Washington where he represented clients on various issues, including railroad and trucking matters.

Mr. Felder holds a bachelors degree from Cornell University, and J.D. from New York University School of Law. He has taught regulatory management at the University of Wisconsin, and is currently involved in designing a regulatory curriculum at American University's School of Public Affairs.

Mr. Felder currently resides in Bethesda, Maryland, with his wife, Deborah, and two sons, Jon and Jeff. 


\section{Gilbert C. Millman \\ U.S. Nuclear Regulatory Commission}

Mr. Gilbert (Gil) Millman, Program Manager, Codes and Standards, joined the NRC, while it was still the Atomic Energy Commission (AEC), in 1974. His heavy involvement in the standards process started at that time when he was assigned to provide staff support for NRC participation on the ASME Section XI Subcommittee on Nuclear Inservice Inspection, the ASME Boiler and Pressure Vessel Committee, and the ASME Board on Nuclear Codes and Standards. Mr. Millman is now the authorized NRC representative on these high level committees, which focus on, respectively, technical, consensus, and policy matters. He has been, in the past, responsible for preparing and issuing rulemakings that incorporate, by reference, the ASME code into the NRC regulations. He is presently participating on an NRC task group that is developing an implementation plan to respond to commission direction regarding the use of consensus standards. 


\section{Colin Church \\ Consumer Product Safety Commission}

Colin Church is the Voluntary Standards and International Activities Coordinator for the U.S. Consumer Product Safety Commission. He is Chairman of the Regulatory Agencies Work Group, Interagency Committee on Standards Policy; serves on ANSI's Board of Directors, Government Member Council, Consumer Interest Council and Executive Standards Council; is a member of ASTM's Executive Subcommittee of the Committee on Consumer Products; and is a member of UL's Consumer Advisory Council. 


\section{Mary C. McKiel \\ Director, Standards Network \\ U.S. Environmental Protection Agency}

Currently, Mary McKiel is the Director of EPA's Standards Network, Mary has been with EPA for six years. Mary began her career in 1976 as a chemist with the National Archives. From 1981 to 1992, she held several senior positions with the Federal Supply Service of the General Services Administration (GSA), including Director of Quality Standards and Director of Environmental Policy.

A long-time advocate of voluntary standards, Mary has served for eight years on the Board of Directors of the American National Standards Institute (ANSI). She is past Chair of the ANSI Government Member Council and past President of the International Coalition for Procurement Standards.

Since coming to EPA, Mary has established the first standards network of its kind at the Agency. She also represents EPA on the U.S. Technical Advisory Group for the Environmental Management Standards Technical Committee (TC 207) of the International Organization for Standardization (ISO). 


\section{Steven D. McNeely \\ Office of Underground Storag Tanks Environmental Protection Agency}

Steven D. McNeely is an Environmental Protection Specialist with EPA's Office of Underground Storage Tanks (OUST). During his ten years in OUST, he has served as Liaison Officer for EPA Regions 4, 5, 6, 8 and, is currently coordinating with Region 2 to develop their State Underground Storage Tank programs. As a member of OUST's Corrective Action Technologies Team (CATT), he has fostered a wide range of projects to improve the understanding and use of alternative remedial technologies applied at petroleum release sites. $\mathrm{He}$ also serves as the Project Officer managing EPA's Risk-Based Corrective Action (RBCA) Training Cooperative Agreement with ASTM.

On February 26, 1997, Mr. McNeely received a Gold Metal from EPA Administrator, Carol Browner, for managing the Partnership in RBCA Implementation (PIRI) - a public-private partnership which fosters RBCA training and implementation in State Underground Storage Tank programs. 


\section{Caroline B. Purdy, Ph.D \\ Program Manager for Characterization, Monitoring, and Sensor Technology Integrated Program \\ U.S. Department of Energy}

Dr. Purdy is the Program Manager for Characterization, Monitoring, and Sensor Technology Integrated Program in the U.S. Department of Energy's Office of Technology Development within the Office of Environmental Management (EM). She is responsible for establishing and managing a national applied R\&D program to develop technologies for characterizing the waste and waste environments throughout the DOE complex, and for developing sensors for subsurface characterization, for site closure and compliance monitoring, and for process monitoring of waste treatment.

She directs a program of research, development, and demonstration of advanced environmental sensors and characterization techniques. The program has a large budget and includes technologies such as: geophysical sensors, laboratory and field chemical sensors and instrumentation, contaminant transport modeling, data fusion, nondestructive assay, and radiological sensors. Characterization technologies are primarily applied to high-level waste in underground storage tanks, mixed waste treatment, decontamination of DOE facilities, locating and measuring concentration levels in contaminant subsurface plumes, and monitoring remediation, contaminant transport and barrier integrity at landfills.

Education: Ph.D in Chemistry, 1991, University of Maryland. Geochemistry with a concentration in nuclear analytical methods.

Geochemist with primary emphasis on using radiouclides produced in the atmosphere as tracers to delineate ground water movement.

Areas of expertise:

- Understand the atmospheric and subsurface production mechanisms of rare isotopes used as ground water tracers.

- Using cosmogenically produced isotopes as tracers to identify ground water recharge zones, ground water flow patterns, and dating the ground water.

- Using geochemical modeling programs to predict ground water chemical composition. 


\section{Gregory E. Saunders \\ Deputy Director, Acquisition Practices \\ Department of Defense}

Gregory E. (Greg) Saunders is the Deputy Director of Acquisition Practices in the Office of the Assistant Secretary of Defense for Economic Security. His principle focus is on implementing the Department's Specification Reform initiative, developing policies and procedures to enable DoD components to buy more commercial products and nondevelopmental items (NDI), and to use more commercial buying practices. As the OSD focal point for advocating use of NDI, he served on two Defense Science Board Studies on Commercial Components, both chaired by Secretary Perry, and was responsible for DoD's implementation of their recommendations; He is working with the Defense Standards Improvement Council on reform of the Military Specifications and Standards program; has testified before congress on DOD's progress implementing a statutory preference for NDI; and has served on numerous study groups.

He oversees the Defense Standardization program and is responsible for policy governing such issues as the development and use of Qualified Manufacturers Lists, use of industry standards, development of performance standards, and others.

Mr. Saunders came to his current position in 1986 from the Defense Standardization Program Office where he was responsible for the DoD's program to adopt and use standards produced by voluntary standards organizations and for various otherr aspects of standardization policy.

He is an engineering graduate of the University of Evansville in Evansville Indiana, serves on the Aerospace Council of the Society of Automotive Engineers, represents the Department of Defense on the American National Standards Institute's Government Member Council, serves on their Board of Directors, and Chairs the Standards and Data Services Committee.

Greg may be reached at his internet address "Saundege@acq.osd.mil" 


\section{Mr. James D. Nicolo \\ Director \\ Engineering and Technical Services Office \\ Defense Industrial Supply Center}

Mr. James Nicolo has over 36 years of government service with experience ranging from Production Engineering of metal parts to standardization of industrial hardware items. He received his undergraduate degree in mechanical engineering from Villanova University in 1961. In 1976 Mr. Nicolo joined DISC with an initial assignment of managing item standardization programs such as Metrication, Voluntary Standards, Specification and Standards and commercialization of industrial hardware spare parts.

In 1984 Mr. Nicolo introduced the Test and Evaluation Program at DISC and for his achievements in this area he received the Secretary of Defense Superior Management Award.

Currently Mr. Nicolo is the Deputy Director of the Engineering and Technical Services Office at DISC. He has held this position for over 7 years and has been instrumental in fostering a collaborative industry and government approach to optimizing the standardization of industrial hardware spare parts through the specification and standards process. 


\section{Bruce L. Mahone \\ Director, Standardization \\ Aerospace Industries Association}

Bruce Mahone has been working in aerospace standardization since 1989, first as Assistant Manager, Technical Division of the American Gear Manufacturers Association and now as Director of Standardization for the Aerospace Industries Association of America. In his capacity as Executive Secretary of AIA's National Aerospace Standards Committee, he is responsible for the largest collection of trade association standards in the United States. He also serves as Secretary of the primary international forum for aerospace standardization, ISO Technical Committee 20. Standards he has worked on run the gamut from electrical and mechanical parts to materials, lubricants, and style manuals. A member of the Standards Engineering Society, Mr. Mahone also facilitates government acquisition reform as it pertains to aerospace manufacturers through AIA's Early Warning Project Group. In addition to his contributions to the World Standards Day Planning Committee, his recent activities have strongly emphasized coordinating industry views on national space policy and converting military specifications to commercial standards.

He completed his mechanical engineering degree in 1976, with an emphasis on aerospace systems. 


\section{Howard M. Bloom \\ Deputy Director \\ Manufacturing Engineering Laboratory \\ National Institute of Standards and Technology}

Mr. Bloom is currently Deputy Director of the Manufacturing Engineering Laboratory at the National Institute of Standards and Technology (NIST). He has over thirty years of experience in the application of information technology to engineering applications with the last 16 years specifically in manufacturing engineering. At NIST, he has directed research and development of Computer Integrated Manufacturing (CIM) applications and interface specifications in the areas of design, process planning, production control and the information infrastructure to support these applications (e.g. distributed database systems and factory networks).

He has a driving interest in national research and standards efforts related to the application of information technology for manufacturing, with special interest in the development of product data standards, for which he spent 12 years directing the NIST efforts. 


\section{Richard J. (Rick) Serbu U.S. Department of Energy}

Rick Serbu has been the DOE Technical Standards Program Manager since October 1994. He is responsible for overall coordination and direction of the Department's Technical Standards Program and technical standards activities, and integration of these activities into the recently established Department Standards Program. Rick joined DOE in 1990 and was appointed Acting Director of the Safety Inspection Division with responsibility for the Technical Safety Appraisal Component of DOE's Tiger Team Assessments. He subsequently served as Director of the Nuclear Safety Technology Division and, later, Director of the Risk Analysis and Technology Division; in these positions, Rick was active in the 90-2 Coordination Committee, rulemaking, and S/RIDs (EH representative), and had responsibility for EH-30 standards management and management of non-nuclear safety analysis, risk analysis, chemical safety, and natural phenomena hazards mitigation programs. He also served as a core member of the Headquarters Support Group for the Department Standards Committee, and has been instrumental in establishing the Department Standards Program. Rick was also one of the founding members of the EH Policy/Standards Process Improvement Team.

Prior to coming to DOE, Rick worked for the Nuclear Regulatory Commission, Tennessee Valley Authority, and Knolls Power Atomic Laboratory. His work for these organizations was focused in the areas of radiological protection/training, health physics, program management, shift supervision, and development and review of regulatory guidance and standards. He represented the NRC on various standards committees of the Health Physics Society, American National Standards Institute, American Nuclear Society, and American Society for Testing and Materials. Rick is currently a member of the Health Physics Society.

Rick served for over six years as an Air Force Pilot/Aircraft Commander during the Vietnam era. In addition to his combat experience during three Southeast Asia tours, Rick served in the 99th Bomb Wing Standardization and Evaluation Unit. He received his B.A. degree in Chemistry from the State University College in Potsdam, New York. 


\section{Michael C. Schagrin \\ Standards Program Manager \\ U.S. Department of Transportation}

Michael C. Schagrin is the Standards Program Manager for the United States Department of Transportation's Intelligent Transportation Systems Joint Program Office. The U.S. DOT is pursuing an ambitious program of expediting the development of ITS volunteer standards and Mr. Schagrin is responsible for ensuring successful implementation of that program. Prior to joining the U.S. DOT, Mr. Schagrin worked for the U.S. Department of Defense and was responsible for the development and procurement of sophisticated Navy shipboard combat systems.

Mr. Schagrin holds a B.S. im Mechanical Engineering from the University of New Hampshire and an M.S. in Systems Engineering from George Mason University. 


\section{Dr. J. Michael Fitzmaurice Director \\ Center of Information Technology \\ U. S. Agency for Health Care Policy and Research Office of Science and Data Development}

Dr. Fitzmaurice is Director, Center for Information Technology, Agency for Health Care Policy and Research. He joined the Public Health Service in 1987 as Director of the National Center for Health Services Research and Health Care Technology Assessment, coming from the Health Care Financing Administration where he was Acting Director, Office of Research. Previously, as branch chief in the Office of Research he directed the development of Medicare's Prospective Payment System. Dr. Fitzmaurice received his Ph.D. in Economics in 1972 from the University of Maryland. He has undergraduate degrees from St. Joseph's College (Rensselaer, $\mathbb{I N}$ ) in Mathematics and in Economics. He is an adjunct Associate Professor in the University College Graduate School, University of Maryland.

He served on the White House Health Reform Task Force, Working Groups on Information Systems and on Administrative Simplification, which made recommendations to Hillary Rodham Clinton, Chair of the Task Force, on the use of information technology in health care reform.

Dr. Fitzmaurice represents AHCPR as a member of the White House Information Infrastructure Task Force (IITF), Committee on Applications and Technology. Currently he is actively involved in developing health information technology research programs at AHCPR and in implementing the requirements of P.L. 104-191 for the Secretary of Health and Human Services to adopt national patient care data standards for selected electronic health care transactions. 


\section{Donald E. Marlowe \\ Director \\ Office of Science and Technology \\ Center for Devices and Radiological Health \\ U. S. Food and Drug Administration}

Mr. Marlowe is the Director, Office of Science and Technology, Center for Devices and Radiological Health for the Food and Drug Administration. Since 1995, Mr. Marlowe has provided leadership for the Office of Science and Technology (OST). He directs the CDRH laboratory programs in areas of electronics, computer science, materials science, mechanical engineering, toxicology, bioeffects, and physics. He previously served at FDA as Director, Division of Mechanics and Materials Science, OST (1984-1995); Senior Mechanical Engineer, Research and Testing Staff, Bureau of Medical Devices (1977-1983); Chief, Dynamic Measurement Group (1975-1977); Project Leader, Composite Materials Program (1973-1975); and Mechanical Engineer in the Engineering Mechanics Section, National Bureau of Standards, Department of Commerce (1963-1973). Mr. Marlowe received a A.B. in Physics (1964), a B.M.E. (1964) and an M.S.E. in Solid Mechanics from Catholic University (1966). He also holds several technical committee assignments and professional society memberships, including the American Society of Mechanical Engineers, the Association for the Advancement of Medical Instrumentation, and the American Society for Testing and Materials. 


\section{Dr. Gary Fischman \\ Office of Science and Technology \\ Center for Devices and Radiological Health \\ U. S. Food and Drug Administration}

Dr. Gary Fischman is a consulting laboratory specialist in hard materials in the Office of Science and Technology, Center for Devices and Radiological Health, Food and Drug Administration. In his two year tenure at the FDA, Dr. Fischman has been involved in a number of standards-based activities including the development of an abrasion standard and the rewriting of an Aluminum Oxide Material Specification for ASTM and a Ceramic Degradation Standard for ISO. Dr. Fischman is also a member of one of the new Speciality Task Groups formed in the Center for Devices and Radiological Health, a member of ASTM F-04 and C-28, and delegate for ISO TC-194.

Previous to joining the Food and Drug Administration, Dr. Fischman was a tenured Associate Professor of Ceramic Engineering at the New York State College of Ceramics at Alfred University. While there, he served as the Director of the Institute for Bioceramics and a Director of the Alfred University Satellite of the NSF Industry University Center for Biosurfaces. He is currently the President of the National Institute of Ceramic Engineers, a Governor for the American Association of Engineering Societies, and an active member and Fellow of the American Ceramic Society. 
Section 8

\section{Conference Participants}



Final Participants List

Using Voluntary Standards in the Federal Government September 8, 1997

Michael Agudo

USDA-RUS-TSD-TB

1400 Independence Ave., SW

Rm. 1569

Washington, DC 20250-1569 USA

Telephone: 202/720-0980

Emelia Altomari

Defense Ind. Supply Ctr.

700 Robbins Ave.

Philadelphia, PA USA

Telephone: 215/697-6827

Fax: (215) 697-0401

EMAIL: altomari@disc.d/a.mil

Roger Amorosi

DTL

1202 Lakeview Pkwy.

HC73 Box 854A

Locust Grove, VA 22508 USA

Telephone: 540/972-4324

Carl Anderson

U.S. Dept. of the Interior

381 Elden St.

Herndon, VA 22071 USA

Telephone: 703/787-1608

Fax: (703) 787-1575

EMAIl: Carl Anderson@mms.gov

Craig Annear

EPA

401 M St., SW

Washington, DC 20460 USA

Telephone: 202/260-5328

Fax: 202/260-5328
Thomas Bacon

General Services Administration

FSS-FCOE

CM4, Rm. 705

Washington, DC 20406 USA

Telephone: 703/305-6573

Fax: 703/305-6731

EMAIl: thomas.bacon@gsa.gov

Thomas Baines

EPA

2565 Plymouth Rd.

Ann Arbor, MI 48105 USA

Telephone: $313 / 668-4366$

Frank Bandy

Unified Industries, Inc.

6551 Loisdale Ct., Suite 400 .

Springfield, VA 22150 USA

Telephone: 703/922-9800

Fax: 703/971-5892

John Paul Barber

4510 Avondale St.

Bethesda, MD 20814 USA

P. Yvonne Barnes

NIST

Bldg. 220, Rm. A305

Gaithersburg, MD 20899 USA

Telephone: 301/975-2345

Fax: 301/975-2345

EMAIl: yvonne.barnes@nist.gov 
Edward Barrett

Ship Introduction

901 M St., SE

Rm. 4

Washington, DC 20398-5540 USA

Telephone: 202/685-5550

Fax: 202/685-5033

Carlos Beauchamp

NIST

Bldg. 224, Rm. B166

Gaithersburg, MD 20899 USA

Telephone: 301/975-6411

Eugene Beuttel

DISC

700 Robbins Ave.

Philadelphia, PA 19001 USA

Telephone: $215 / 697-3457$

Fax: (215) 697-3457 ext0401

EMAIL: ebeuttel@disc.mil

Donald Bieniewicz

U.S. Dept. of the Interior 1849 C St., NW

OS, PPA

Washington, DC 20240 USA

Telephone: 202/208-4915

Howard Bloom

NIST

Bldg. 820, Rm. B322

Gaithersburg, MD 20899-0001 USA

Telephone: 301/975-3401

Marcelino Borges

U.S. Customs Service

1301 Constitution Ave., NW

Rm. 7113

Washington, DC 20229 USA

Telephone: 202/927-1060

Fax: 202/927-2060
John Bosch

EPA

EMC Old Pipe Rd.

MD 19

RTP, NC 27711 USA

Telephone: 919/541-5583

Fax: 919/541-1039

Carol Bowers

GEO-Institute

1801 Alexander Bell

Reston, VA 20191-4400 USA

Telephone: 703/295-6352

Fax: 703/295-6350

EMAIl: cbowers@asce.org

Lynn Bradley

ASTPHLD

1211 Connecticut Ave., NW

Rm. 608

Washington, DC USA

Telephone: 202/822-5227

Terence Brady

USDA-Off. of Gen. Council

1400 Independence Ave., SW

Washington, DC 20250-1414 USA

Telephone: 202/720-8103

Richard Brawley

Defense Fuel Supply Ctr.

8725 John J. Kingman

Dfsc-Bp 2834

Ft. Belvoir, VA USA

Telephone: 703/767-8357

Maureen Breitenberg

NIST

Bldg. 820, Rm. 318

Gaithersburg, MD 20899-0001 USA

Telephone: 301/975-4031 
Robert Brickey

Naval Construction Bat.

100 23rd Ave., Rm. 15E2B

Pt. Hueneme, CA 93043 USA

Telephone: 805/982-5593

Fax: 805/982-5196

EMAIl: bbrickey@cbcph.navy.mil

Stanley Brown

FDA/CDRH/OST/DMMS

12200 Wilkens Ave.

Rockville, MD 20852 USA

Telephone: $301 / 827-3927$

Fax: 301/827-3127

EMAIl:sab@cdrm.fda.gov

Roger Burkhart

FDA/CDRH/OHIP/DMQRP

1350 Piccard Dr.

HFZ-240

Rockville, MD 20850 USA

Telephone: 301/594-3303

Jim Burtle

Federal Communications Commission

1919 M St., NW

Washington, DC USA

Telephone: 202/418-2445

EMAIL: JBURTLE@FCC.gov

Cathy Carr-Clinch

Woodward Clyde

200 Orchard Ridge Dr.

Suite 200

Gaithersburg, MD USA

Telephone: 301/258-9780
Mike Carter

U.S. Dept of Energy

19901 Germantown Rd., Rm. EM-76

Germantown, MD 20874 USA

Telephone: 301/903-7945

Fax: 301/903-7613

EMAIL:mike.carter@em.doe.gov

Teresa Cendrowska

ASTM

100 Barr Harbor Dr.

W. Conshohocken, PA 19428 USA

Telephone: 610/832-9718

Fax: 610/832-9666

EMAIl: tcendrow@astm.org

Kish Chakrabarti

CDRH/FDA

1350 Piccard Dr.

HFZ-240

Rockville, MD 20850 USA

Telephone: 301/594-3313

Alexander Chasan

U.S. Navy-CDNSWCCD

9500 MacArthur Blvd./Codé 641

60-104

W. Bethesda, MD 20817-5700 USA

Telephone: $301 / 227-4839$

Fax: 301/227-4789

Ford E. Chinworth

NAVFAC HQ

200 Stovall St.,

Code 151

Alexandria, VA 22303 USA

Telephone: 703/325-8943

Fax: 703/325-2261

EMAIl: fechinworth@hq.navfac.navy.mil 
Colin B. Church

SPSC

Room 604C

Washington, DC 20207 USA

Telephone: 301/504-0554

Daniel Chwirut

FDA

12200 Wilkins Ave.

HFZ-150

Rockville, MD 20852 USA

Telephone: 301/827-3930

Fax: 301/443-5259

EMAIl: djc@cdrh.fda.gov

James Coaker

U.S. Postal Service

4301 Wilson Blvd.

Suite 300

Arlington, VA 22203-1861 USA

Telephone: 703/526-2754

Fax: 703/526-2711

EMAIL: jcoaker@email.usps.gov

Elizabeth Cocke

U.S. Dept. of HUD

451 7th St., SW

Consumer Regulatory Affairs

Washington, DC 20410 USA

Telephone: 202/708-6401

Belinda Collins

NIST

Bldg. 820, Rm. 282

Gaithersburg, MD 20899-0001 USA

Telephone: $301 / 975-4000$.
Guy Colonna

NFPA

1 Batterymarch Park

Quincy, MA 02269 USA

Telephone: 617/984-7435

Patrick Cooke

NIST

Bldg. 820

Gaithersburg, MD 20899-0001 USA

Telephone: 301/975-4033

Alan Cookson

NIST

Bldg. 220, Rm. B-358

Gaithersburg, MD 20899 USA

Telephone: 301/975-2220

Shannon Corcorn

ASSE

28901 Clemems Rd \#100

Westlake, OH 44145 USA

Telephone: 440/835-3040

Fax: (440) 835-3488

EMAII: ASSE@IX.NETCOM.COM

Lake Coulson

NEMA

1300 N. 17th St.

Rosslyn, VA 22209 USA

Telephone: 703/841-3245

Fax: (703) 841-3345

EMAIl- Lak-Coulson@nema.org

James Crabtree

U.S. Dept. of Energy

19901 Germantown Rd.

NN 512

Germantown, MD 20874 USA

Telephone: 301/903-6008 
Andrew Culbertson

DDR\&4E/AT

3080 Defense Pentagon

3D1089

Washington, DC 20301-3080 USA

Telephone: 703/695-0005

Fax: 703/695-4885

EMAII: cukberas@acq.osd.mil

Thomas Daily

General Services Admin.

FSS-FCOE

CM4, Rm. 705

Washington, DC 20406 USA

Telephone: 703/305-5149

Fax: 703/305-6731

EMAIl: thomas.daily@gsa.gov

Christine DeVaux

NIST

Bldg. 820, Rm. 318

Gaithersburg, MD 20899-0001 USA

Telephone: 301/975-5508

Jerry Dickey

Afmet Cal Deti

813 Irving Wick Dr.

Heath, OH 93056 USA

Francis Dietz

ASNE International

1828 L St., NW

Suite 900

Washington, DC 20036 USA

Telephone: 202/785-3756

Fax: (202) 429-9417

EMAIL: dietz@asme.org

Khouane Ditthavong

DynCorp

300 North Lee St., Suite 500

Alexandria, VA 22151 USA

Telephone: 703/519-1208
Robert Draim

Naval Seas Systems Cmd.

2531 Jefferson Davis Hwy.

SEA 03B

Arlington, VA 22242-2439 USA

Telephone: $703 / 602-2439$

Fax: 703/602-2443

EMAIL: draim.robert@hq.navsea.navy.mil

Russell Dupre

Naval Surface Warfare Ctr.

101 Strauss Ave.

Indian Head, MD 20640-5035 USA

Telephone: $301 / 749-4700$

Fax: 301/743-4102

EMAIL:8410t4@smtphost.1h.navy.mil

John Durrant

Institute of ASCE

1801 Alexander Bell

Reston, VA 20191-4400 USA

Telephone: 703/295-6099

Fax: 703/295-6361

EMAIL: jdurrant@asce.org

Ken Duvall

Dept. of Energy

1000 Independence Ave., SW

Washington, DC USA

Telephone: 202/586-0242

EMAIl: Kenneth.Duvall@DOE.EH.GOV

Charles Ehrlich

NIST

Bldg. 820, Rm. 318

Gaithersburg, MD 20899-0001 USA

Telephone: 301/975-4834

Charles Eirkson

FDA

7500 Standish Place, HFV- 140

Rockville, MD 20855 USA

Telephone: 301/594-1683 
Barbara Ellison

General Services Administration.

FSS-FCOE - CM4, Rm. 705

Washington, DC 20406 USA

Telephone: 703/305-7178

Fax: 703/205-6731

EMAIL: barbara.ellison@gsa.gov

Carla Falco

ASTM

100 Barr Harbor Dr.

W. Conshohocken, PA 19428-2959 USA

Telephone: 610/832-9605

Fax: 610/832-9623

EMAIl: cfalco@astm.org

Alim Fatah

NIST/Law Enforcement Stnd.

Bldg. 225, Rm. A323

Gaithersburg, MD 20899 USA

Telephone: 301/975-2757

Fax: 301/948-0978

EMAII: aafatah@mailserver2.nist.gov

Richard Feigel

ASME

345 E. 47th St.

Hartford, CT 06102-3001 USA

Telephone: 212/705-8500

Richard Felder

U.S. Dept. of Transportation

100 Seventh St., SW

Washington, DC 20500 USA

Telephone: 202/366-4595

Bob Fenichel

National Communications System

701 S. Court House Rd.

Arlington, VA 22204 USA

Telephone: 703/607-6190

Fax: (703) 607-4830

EMAIl: fenicher@ncs.gov
Charles Finder

FDA/CDRH/OHIP/DMQRP

1350 Piccard Dr., HFZ-240

Rockville, MD 20850 USA

Telephone: 301/827-0009

Patrick Finn

U.S. Dept of Energy

19901 Germantown Rd.

Germantown, MD 20874 USA

Telephone: 301/903-9876

Ruth Fischer

FDA/CDRH/OHIP/DMQRP

1350 Piccard Dr., HFZ-240

Rockville, MD 20850 USA

Telephone: 301/594-3311

Gary Fischman

FDA

12200 Wilkins Ave.

Rockville, MD 20852 USA

Telephone: 301/827-3933

Michael Fitzmaurice

HHS

2101 E. Jefferson St., Suite 602

Rockville, MD 20852 USA

Telephone: 301/594-1483

Glenn Florczak

U.S. Dept. of Energy

19901 Germantown Rd.

Germantown, MD 20874 USA

Telephone: 301/903-9877

Mike Foran

Afmetcal Det 2/MLSR

813 Irving Wick Dr., Suite 4M

Heath, OH 43056-6116 USA

Telephone: 614/788-5060

Fax: (614) 788-5021

EMAIL: FORAN@AFMETACAL.AF.MIL 
Howard Forman

P.O. Box 66

Huntingdon Valley, PA 19006 USA

Telephone: 215/947-4154

Juliet Fried

ICF Kaiser International

9300 Lee Highway

Fairfax, VA 22031 USA

Telephone: 703/934-3019

Fax: 703/934-3740

EMAIL: jfried@icfkaiser.com

Geoffrey Frohnsdorff

NIST

Bldg. 226, Rm. B368

Gaithersburg, MD 20899-0001 USA

Telephone: 301/975-6706

Fax: 301/990-6891

EMAII: geoffrey.frohnsdorff@nist.gov

Harry Frost

Def. Ind. Sup. Ctr.

700 Robbins Ave.

Philadelphia, PA 19111 USA

Telephone: $215 / 697-6805$

Fax: (215) 697-1172

Charles Gallagher

General Services Admin.

FSS-FCOE

CM4, Rm. 705

Washington, DC 20406 USA

Telephone: 703/305-6023

Fax: 703/305-6731

EMAIL: charles.gallagher@gsa.gov

Lawrence Galowin

NIST

Bldg. 820, Rm. 318

Gaithersburg, MD 20899-0001 USA

Telephone: 301/975-4022
Ronald Garbin

US Dept of Agriculture

1400 Independence Ave

Washington, DC 20250 USA

Telephone: 202/720-8026

Fax: (202) 690-2988

EMAIL: RONALD.GARBIN@USDA.gov

Wendell Garner

General Services Admin.

FSS-FCOE

CM4, Rm. 705

Washington, DC 20406 USA

Telephone: 703/305-5896

Fax: 703/305-6731

EMAIL: wendell.garner@gsa.gov

Eric Gentsch

Logistics Mgmt Institute

2000 Corp Ridge

McLean, VA 22102 USA

Telephone: 703/917-7226

Fax: (703) 917-7530

EMAIL: egentsch@lmi.org

Robert Gettings

NIST

Bldg. 202, Rm. 112

Gaithersburg, MD 20899-0001 USA

Telephone: 301/975-2015

Maninderpal Gill

Sys. Anal. \& Integ. Lab

NASA, MSFC

FL01

MSFC, AL 35812 USA

Telephone: 205/544-2557

Thomas Gills

NIST

Bldg. 202, Rm. 112

Gaithersburg, MD 20899-0001 USA

Telephone: 301/975-2015 
Robert Gladhill

NIST

Bldg. 820, Rm. 318

Gaithersburg, MD 20899-0001 USA

Telephone: 301/975-4273

Suzy Glucksman

ASME

1828 L St., NW

Suite 906

Washington, DC 20036 USA

Telephone: 202/785-3756

Frederick Gray

DOI MMS Operations Analysis

381 Elden St,

Herndon, VA 20170 USA

Telephone: 703/787-1027

Fax: (703) 787-1555

EMAIL:GRAYF@MMS.GOV

Dave Green

Federal Highway Admin.

4007 th St., SW

HFL-22

Washington, DC 20590 USA

Telephone: 202/366-9477

Jonathan Green

AMECA

1101 15th St., NW

Suite 607

Washington, DC 20005 USA

Telephone: 202/898-0145

Fax: 202/878-0148

EMAIL: amecainc@aol.com

James Griffin

GSA/MK

1800 F St., NW

Rm. 2239

Washington, DC 20405 USA

Telephone: 202/219-2370
Charles Gunzburg

Div Mammo/Rad Prog-CDRH

1350 Piccard Dr., HFZ-240

Rockville, MD 20850 USA

Telephone: 301/594-3587

Manuel Gutierrez

ASME International

345 E 47th St.

New York, NY 10017 USA

Telephone: 212/705-8562

Fax: (212) 705-8502

EMAIl: gutierrezm@asme.org

Dave Haataja

Underwriters Labs

818 18th St., NW

Suite 230

Washington, DC 20006 USA

Telephone: 202/296-7840

Sandra Hale

NIST

Bldg. 820, Rm. 318

Gaithersburg, MD 20899-0001 USA

Telephone: 301/975-3609

Charlie Harper

USDA-RUS-TSD-OPB

1400 Independence Ave., SW

Stop 1598

Washington, DC 20250-1500 USA

Telephone: 202/720-8663

Fax: 202/720-4099

Kathleen Hastings

U.S. Dept. of HHHS

5600 Fishers Lane

Office of Policy HF 23

Rockville, MD 20857 USA

Telephone: 301/877-3344

Fax: (301) 493-6906

EMAII: khasting@bangate.fda.gov 
Jeanette Helfrich

US Dept of Energy

1000 Independence Ave., SW GC 52

Washington, DC 20585 USA

Telephone: 202/586-4218

Martha Hendrick-Smith

USCG Marine Safty Lab

1082 Shennecossett Rd.

Groton, CT 06340 USA

Telephone: 860/441-2645

Fax: (860)441-2641

EMAIL:mhendrick@gamma.rdc.uscg.mic

Jerome Hendrickson

IAPMO

4621 North 33rd St.

Arlington, VA 22207 USA

Telephone: 703/237-9667

Peter Heydemann

NIST

Bldg. 820, Rm. 318

Gaithersburg, MD 20899-0001 USA

Telephone: $301 / 975-4500$

Howard Hime

U.S. Dept. of Transportation

2100 Second St., SW

Washington, DC 20593-0001 USA

Telephone: 202/267-0002

John Holtmann

Shook Hardy \& Bacon

801 Pennsylvania Ave., NW

Suite 600

Washington, DC 20004 USA

Telephone: 202/783-8400

Fax: 202/783-4211
Peter Huddleston

LLNL/DOE

20201 Century Blvd., Floor 1

Germantown, MD 20874 USA

Telephone: 301/916-7723

Gerard Iannelli

NIST

Bldg. 820, Rm. 306

Gaithersburg, MD 20899-0001 USA

Telephone: 301/975-3690

Laura James

FDA/OC/Policy

5600 Fishers Lane

Rm. 15-74, HF-23

Rockville, MD 20857 USA

Telephone: 301/827-3344

Nicholas Jergovich

Maritime Administration

400 Seventh St., SW

Rm. 2109

Washington, DC 20590 USA

Telephone: 202/366-1860

Kenneth Jewett

MSEL/NIST

Bldg. 223, Rm. B309

Gaithersburg, MD 20899-0001 USA

Telephone: 301/975-2608

Fax: 301/975-5012

EMAIl: kjewett@nist.gov

Rajani Joglekar

EPA

401 M St., SW

$5304 \mathrm{~W}$

Washington, DC 20460 USA

Telephone: $703 / 308-8806$

Fax: 703/308-7903

EMAIL:joglekar.rajani@epamail.epa.gov 
Krista Johnsen-Leuteritz

NIST

Bldg. 820, Rm. 282

Gaithersburg, MD 20899-0001 USA

Telephone: 301/975-5104

Stephen Kale

Systematic Mgmt. Services

20201 Century Blvd.

Germantown, MD 20874 USA

Telephone: 301/353-0072

Miguel Kamat

FDA

1350 Piccard Dr.

HFZ-240

Rockville, MD 20850 USA

Telephone: 301/827-2968

Gerald Kelley

Logistics Mgmt. Institute

2000 Corporate Ridge

McLean, VA 22102 USA

Telephone: 703/917-7222

Fax: (703) 917-7596

EMAIL: jkelley@lmi.org

Carl Kersten

Civil Eng Support Office

1000 23rd Ave.

Rm. 232

Port Hueneme, CA 93043 USA

Telephone: 805/982-2412

Charles Kirtz

US EPA

401 M St., SW

Washington, DC USA

Telephone: 202/260-7565
William Koch

NIST/CSTL

Bldg. 222, Rm. A317

Gaithersburg, MD 20899 USA

Telephone: 301/975-3146

Fax: 301/975-3845

EMAIL:william.koch@nist.gov

J. Bruce Kolowich

EPA

2565 Plymouth Rd., TSD/LIS-FG

Ann Arbor, MI 48105 USA

Telephone: 313/668-4582

Kitty Kono

ASTM

100 Barr Harbor Dr.

W. Conshohocken, PA USA

Telephone: 610/832-9687

John Koper

Naval Air Sys. Command

22347 Cedar Point Rd.

Unit 6, Bldg. 2185

Patuxent River, MD 20670-1161 USA

Telephone: 301/342-7073

Fax: 301/757-1853

EMAIL: koperjm.nimitz@navair.navy.mil

Jane Koska

2401 Calvert St., NW

Rm. \#323

Washington, DC 20008 USA

Telephone: $202 / 662-4865$

Fax: 202/783-4211

Richard Kuchnicki

Council of Amer. Bldg Off.

5203 Leesburg Pike, Suite 708

Falls Church, VA 22041 USA

Telephone: 703/931-4533

Fax: 703/379-1546

EMAIL: kuchnicki@cabo.org 
Melissa Kuckro

American Chemical Society

1155 16th St., NW

330 Othmer

Washington, DC 20036 USA

Telephone: 202/872-4354

Walter Leight

NIST

Bldg. 820, Rm. 282

Gaithersburg, MD 20899-0001 USA

Telephone: 301/975-4000

Edward Levy

Office of Gen. Counsel/DOE

1000 Independence Ave., SW

GC-72

Washington, DC 20585 USA

Telephone: 202/586-2928

Fax: 202/586-4116

EMAIL: edward.levy@hq.doe.gov

June Ling

ASME International

345 E 47th St.

New York, NY 10017 USA

Telephone: $212 / 705-8500$

Fax: (212) 705-8502

EMAIL: lingi@asme.org

Bruce Mahone

AIA

Washington, DC USA

Telephone: 202/371-8462

E. Maisano

Def. Ind. Sup. Ctr.

700 Robbins Ave.

Philadelphia, PA 19111 USA

Telephone: $215 / 697-2765$
Mark Malander

Mobil Business Resources

3225 Gallows Rd., 6W017

Fairfax, VA 20171 USA

Telephone: 703/849-3429

Brian Mansir

Logistics Mgmt Institute

2000 Corporate Dr.

McLean, VA 22102 USA

Telephone: 703/917-7282

Fax: (703)917-7597

EMAIL:BMANSIR@LMI_ORG

Peter Marigliano

ACIL, Inc.

1629 K St., NW

Rm. 400

Washington, DC 20006 USA

Telephone: 202/887-5872

Donald Marlowe

FDA

9200 Corporate Blvd.

Rockville, MD 20850 USA, ;

Telephone: 301/443-2444 ?

William Marnane

FDA

7500 Standish Place

HFV-140

Rockville, MD 20855 USA

Telephone: 301/594-0678

Sergio Mazza

ANSI

11 West 42nd St.

New York, NY USA

Telephone: 212/642-4900 
W. Michael McDavit

EPA

401 M St., SW

2136

Washington, DC USA

Telephone: 202/260-7202

Bruce McDonald

NIST

Bldg. 202, Rm. 112

Gaithersburg, MD 20899-0001 USA

Telephone: $301 / 975-2015$

Mary McKiel

EPA

401 M St. SW

Washington, DC 20460 USA

Telephone: 202/260-3584

Mary McKnight

NIST

Bldg. 226, Rm. B350

Gaithersburg, MD 20899 USA

Telephone: 301/975-6714

Fax: 301/990-6891

EMAIl: mary.mcknight@nist.gov

Steven D. McNeely

EPA

401 M St., SW

$\mathrm{MC5} 403 \mathrm{G}$

Washington, DC 20560 USA

Telephone: 703/603-7164

John Meagher

AIHA

2700 Prosperity Ave.

Fairfax, VA 22031 USA

Telephone: $703 / 849-8888$

Fax: 703/207-3561

EMAIL: jmeagher@aiha.org
Richard Meier

Meadowbrook International

11141 Timberhead Ct.

Reston, VA 20191 USA

Telephone: 703/295-0838

Fax: 703/295-0838

EMAIL:meadowbrookintl@worldnet.att.net

Rick Mendlen

HUD

4577 th St. SW

Rm. 9156

Washington, DC 20410 USA

Telephone: 202/708-0614

Gilbert Millman

NRC

Mail Stop T-10-D20

Washington, DC 20555 USA

Telephone: 301/415-5843

Charles Miro

ASHRAE

1828 L St., NW

Rm. 906

Washington, DC 20036-5104 USA

Telephone: 202/833-1830

Roy Mullinix

HUD

4517 th St. SW

Suite 427

Washington, DC 20410-3600 USA

Telephone: 202/708-0614

Scott Murphy

ASTM

100 Barr Harbor Dr.

W. Conshohocken, PA 19428 USA

Telephone: 610/832-9685

Fax: 610/832-9668

EMAIl: smurphy@astm.org 
John Murray

U.S. Dept. of the Treasury

3700 East West Hwy.

Rm. 1005A PGMC II

Hyattsville, MD 20782 USA

Telephone: 202/874-2760

Cyrus Nasseri

U.S. Dept. of Energy

1000 Independence Ave., SW

Washington, DC 20585 USA

Telephone: 202/586-9138

Fax: (202)586-4617

EMAIl: CYRUS.NASSERI@HQ.DOE.GOV

James Nicolo

DISC, DOD

Washington, DC USA

Telephone: $215 / 697-3001$

Joseph Nilsen

Defense Logistics Agency

2800 S 20th St.,

DPSC-FNS

Philadelphia, PA 19145 USA

Telephone: 215/737-3016

David Nimmer

U.S. Dept. of HUD

451 7th St., SW

Washington, DC 20410 USA

Telephone: 202/708-6401

Anthony ONeill

National Fire Protection Assn.

1110 N. Glebe Rd.

Suite 560

Arlington, VA 22201 USA

Telephone: $703 / 516-4346$

Fax: 703/516-4350

EMAIl:wdc@nfpa.org
Joanne Overman

NIST

Bldg. 820, Rm. 318

Gaithersburg, MD 20899-0001 USA

Telephone: 301/975-4037

Joel Page

NRC

Washington, DC 20555 USA

Telephone: 301/415-6784

Fax: (301)415-5062

EMAIL:JDP2@NRC.GOV

Ken Peabody

ANSI

11 West 42nd St.

New York, NY USA

Telephone: $212 / 642-8908$

Jennifer Peper

Ericson

1635 I St., NW

Suite 600

Washington, DC 20006 USA,

Telephone: 202/783-2200

Fax: (202)783-2206

EMAII: Jennifer.Peper@Ericsson.com

Francine Pinto

Office of Gen. Counse1/DOE

1000 Independence Ave., SW

GC-72

Washington, DC 20585 USA

Telephone: 202/586-7432

Fax: 202/586-0971

EMAIl: francine.pinto@hq.doe.goc

Elizabeth Poisson

TMS, Inc.

18757 N. Frederick Rd.

Gaithersburg, MD 20879 USA

Telephone: 301/670-6390 
Michael Postek

NIST

Bldg. 220, Rm. A-117

Gaithersburg, MD 20899-0001 USA

Telephone: 301/975-2299

Lawrence Presley

FBI

FBI Academy - Rm. 322

Quantico, VA 22135 USA

Telephone: 703/640-1113

Caroline Purdy

Dept. of Energy

Route@EM53-1172

Germantown, MD USA

Telephone: 301/903-7672

Lynne Radack

NIST

Bldg. 820, Rm. 568

Gaithersburg, MD 20899-0001 USA

Telephone: 301/975-3345

Ira Reese

U.S. Customs Service

1301 Constitution Ave., NW

Rm. 7113

Washington, DC 20229 USA

Telephone: 202/927-1060

Fax: 202/937-2060

Bruce Rosen

NIST

Bldg. 820, Rm. 568

Gaithersburg, MD 20899-0001 USA

Telephone: 301/975-3345

Lynne Rosenthal

NIST

Bldg. 820, Rm. 568

Gaithersburg, MD 20899 USA

Telephone: 301/975-3345
James Rossberg

ASCE

1801 Alexander Bell

Reston, VA 20170 USA

Telephone: 703/295-6196

Gergory Saunders

U.S. Dept. of Defense

DUSD (AP)

3B253 Pentagon

Washington, DC 20301 USA

Telephone: 703/695-7458

Mary Saunders

NIST

Bldg. 820, Rm. 318

Gaithersburg, MD 20899-0001 USA

Telephone: 301/975-2396

Michael Schagrin

U.S. Dept. of Transportation

4007 th St. SW

HVH-1

Washington, DC 20590 USA

Telephone: 202/366-2180

John Schell

USDA-RUS-TSD-COEB

1400 Independence Ave., SW

Stop 1598

Washington, DC 20250-1500 USA

Telephone: 202/720-8663

Fax: 202/720-4099

Ron Scherzberg

FDA

7500 Standish Place

MPN-II

Rockville, MD 20855 USA

Telephone: 301/827-0143

Fax: 301/827-5510

EMAIL: rscherzbe@bangate.fda.gov 
Kathleen Schmidt

U.S. Dept. of Energy

1000 Independence Ave., SW

Washington, DC 20585 USA

Telephone: 202/586-5101

Harvey Schock

Product Assurances

309 Bridceboro Rd.

Rm. 1464

Morristown, NJ 08057-1425 USA

Telephone: 609/222-9050

Andrew Schoka

Mitretek Systems

600 Maryland Ave., Suite 755

Washington, DC 20024 USA

Telephone: 202/488-5702

Melani Schultz

NIST

Bldg. 820, Rm. 318

Gaithersburg, MD 20899-0001 USA

Telephone: 301/975-6472

Morton Norman Schwartz

U.S. Dept. of Energy

20030 Century Blvd.

Bldg. 3, Rm. 317

Germantown, MD 20874 USA

Telephone: 301/903-2996

Jane Schweiker

ANSI

7315 Wisconsin Ave.

Rm. 250E

Bethesda, MD 20814 USA

Telephone: 301/469-3363

Fax: (301)469-3361

EMAIl: jschweiker@ansi.org
Susannah Scott

U.S. Dept. of Transportation

525 School St., SW

Suite 203

Washington, DC 20024 USA

Telephone: 202/426-9336

Fax: (202)426-9355

EMAIL: sscott@pop.jpl.nasa.gov

Howard Seltzer

FDA

5600 Fishers Lane

Rm. 16-85

Rockville, MD 20857 USA

Telephone: 301/827-4402

Richard Serbu

U.S. Dept. of Energy

Rm. EH31

Germantown, MD 20854 USA

Telephone: 301/903-2856

Mark Sheehan

ASME International

345 E. 47th St.

New York, NY 10017 USA

Telephone: $212 / 705-8500$

Fax: (212)705-8501

EMAIl: sheehanm@asme.org

Monique Sinmao

ICF Kaiser International

9300 Lee Highway

Fairfax, VA 22031 USA

Telephone: 703/934-3458

Fax: 703/934-3740

EMAIL:msinmao@icfkaiser.com 
Bradley Skarpness

Battelle

505 King Ave., 11-7-61

Columbus, OH 43201 USA

Telephone: 614/424-4315

Peter Smeallie

Advolates for Prof Judge.

600 Woodland Terr.

Alexandria, VA 22302 USA

Telephone: 703/683-1808

Fax: 703/683-1815

Dennis Smith

AMP, Inc.

P.O. Box 3608

210-20

Harrisburg, PA 17105 USA

Telephone: 717/592-6278

Karen Sorber

LMI

2000 Corp Ridge

McLean, VA 22102 USA

Telephone: 703/917-7219

EMAIl: ksorber@lmi.org

Jaclyn Spear

Westinghouse Savannah

511 S. Spring St.

Falls Church, VA 22046 USA

Telephone: 202/225-5415

Amy Spencer

National Fire Protection Assn.

1 Batterymarch Park

P.O. Box 9101

Quincy, MA 02269-9101 USA

Telephone: 617/984-7402

Fax:

EMAIL:
Dennis Steinauer

NIST

Bldg 820, Room 426

Gaithersburg, MD 20899 USA

Telephone: 301/975-2934

Fax:

EMAIL:

Nancy Harvey Steorts

Nancy Harvey Steorts Intl

4689 S.Versailles Av

Dallas, TX 75209 USA

Telephone: 214/522-9211

Fax: (214)522-5929

Joan Sterling

Intertek Testing Services

1325 13th St., NW

Washington, DC 20005 USA

Telephone: 202/265-3378

Carol Stewart

Amer. Inst. Aeron. Astron

1801 Alexander Bell

Reston, VA 20191 USA

Telephone: 703/264-7513

Wayne Stiefel

NIST

Bldg. 820, Rm. 318

Gaithersburg, MD 20899-0001 USA

Telephone: $301 / 975-4011$

Dan Strachan

National Electric Mftg. Assoc.

1300 N 17 th St.

Rosslyn, VA 22209 USA

Telephone: 703/841-3287

Fax: (703)841-3387

EMAIL:DAN_STRACHAN@NEMA.ORG 
Robert Swartz

DISA

10701 Parkridge Blvd.

Rm. 3218

Reston, VA 20191 USA

Telephone: 703/735-3531

Nancy Trahey

NIST

Bldg. 202, Rm. 112

Gaithersburg, MD 20899 USA

Telephone: 301/975-2015

Cathleen Trail

NIST

Bldg. 820, Rm. 318

Gaithersburg, MD 20899-0001 USA

Telephone: 301/975-4462

Chet Trybus

FDA

1350 Piccard Dr.

HFZ-240

Rockville, MD 20850 USA

Telephone: 301/924-9411

Joan Tyler

NIST

Bldg. 820, Rm. 306

Gaithersburg, MD 20899-0001 USA

Telephone: 301/975-5555

Al Vandegriek

FDA

1350 Piccard Dr.

HFZ-240

Rockville, MD 20850 USA

Telephone: 301/594-0866
Thomas Vegella

FDA/CDRH

1350 Piccard St., HFZ-22

Rockville, MD 20852 USA

Telephone: 301/443-7120

Fax: 301/827-0119

EMAIL: txv@cdrh.fda.gov

Stanley Warshaw

NIST

Bldg. 820, Rm. 318

Gaithersburg, MD 20899-0001 USA

Telephone: 301/975-4193

Darlene Watford

EPA/OPPTS/OPPT/NPCD/TB

401 M St., SW

Rm E817, MC 7404

Washington, DC 20460 USA

Telephone: 202/260-3989

Bob Wayland

Sandia National Lab

P.O. Box 5800

MS 1367

Albuquerque, NM 87123 U\$ A

Telephone: 505/845-9771

Fax: 505/844-1390

EMAIl: jrwayla@sandia.gov

Alfons Weber

NIST

Bldg. 221, Rm. B208

Gaithersburg, MD 20899-0001 USA

Telephone: 301/975-2377

Fax: 301/975-3038

EMAIl: aweber@tiber.nist.gov

Richard Weinstein

NASA Headquarters

Code AE

Washington, DC 20546 USA

Telephone: 202/358-0538 
Thomas Weir

National Archives \& Records

8601 Adelphi Rd.

College Park, MD 20740 USA

Telephone: 301/713-7330

James Weitzner

U.S. ALMC

2401 Quarters Rd.

Sam PQMD

Ft. Lee, VA 23801-1705 USA

Telephone: 804/765-4509

Helen Whatley

U.S. Dept. of the Treasury

1425 New York Ave., NW

Rm. 2110

Washington, DC 20220 USA

Telephone: 202/622-1541

Richard White

EPA

401 M St., SW

Washington, DC 20460 USA

Telephone: 202/584-6473

Fax: 202/585-2409

EMAIl:white.dick@epamail.epa.gov

Howard White

Hitachi Instruments, Inc.

3100 N. First St.

San Jose, CA 95134 USA

Telephone: 408/432-0520

Richard Widup

FDA Office of Criminal Investigation

7500 Standish Place

Rockville, MD USA

Telephone: $301 / 294-4057$

Fax: 301/544-1971

EMAIl: rwidup@ora.fda.gov
David Wiley

EPA

401 M St., SW

$5402 \mathrm{G}$

Washington, DC 20460 USA

Telephone: 703/603-7178

William Rowe

U.S. CPSC

433 East West

Bethesda, MD 20914-4408 USA

Telephone: 301/504-0470

Trudie Williams

Dept. of Defense

5203 Leesburg Pike

Falls Church, VA 22204 USA

Telephone: 703/681-5494

Fax: (703)681-7622

Donald Williams, Jr.

Oak Ridge National Laboratory

P.O. Box 2009

Oak Ridge, TN 37831-8065 USA

Telephone: 423/574-8710

Fax: 423/574-0382

EMAIl: dw5@ornl.gov

George Willingmyre

GTW Associates

1012 Parrs Ridge Dr.

Spencerville, MD 20868 USA

Telephone: $301 / 421-4138$

John Woloszyn

Defense Logistics Agency

$2800 \mathrm{~S} 20$ th St.

DPSC-HSL 9-3-E

Philadephia, PA 19145 USA

Telephone: 215/737-4435 
Stephen Woods

Allied Signal, Inc.

PO Box 20, Bldg 200

White Sands Test Fac

Las Cruces, NM 88004 USA

Telephone: 505/524-5607

Arthur Wu

NAVIAC

Washington Navy Yard

Bldg. 218

Washington, DC USA

Telephone: 202/433-8759

Lynne Yedinak

U.S. Dept of Agriculture

1400 Independence Ave., SW

Washington, DC 20250-0243 USA

Telephone: $202 / 690-4941$

Fax: 202/690-0102

EMAIl: eyedinak@usda.gov

Roger Young

General Services Admin.

FSS-FCOE

CM4, Rm. 705

Washington, DC 20406 USA

Telephone: 703/305-6131

Fax: 703/305-6731

EMAIl: roger.young@gsa.gov

Tim Young

Booz, Allen \& Hamilton

8283 Greensboro Dr.

McLean, VA 22102-3838 USA

Telephone: 703/902-5000

Elder Zulfugarzade

NIST

Bldg. 820, Rm. 318

Gaithersburg, MD 20899-0001 USA

Telephone: 301/975-4412 

